Engineer Research and

Development Center

\title{
Non-Nuclear Alternatives to Monitoring Moisture-Density Response in Soils
}

Ernest S. Berney IV, Mariely Mejías-Santiago,

March 2013 and James D. Kyzar

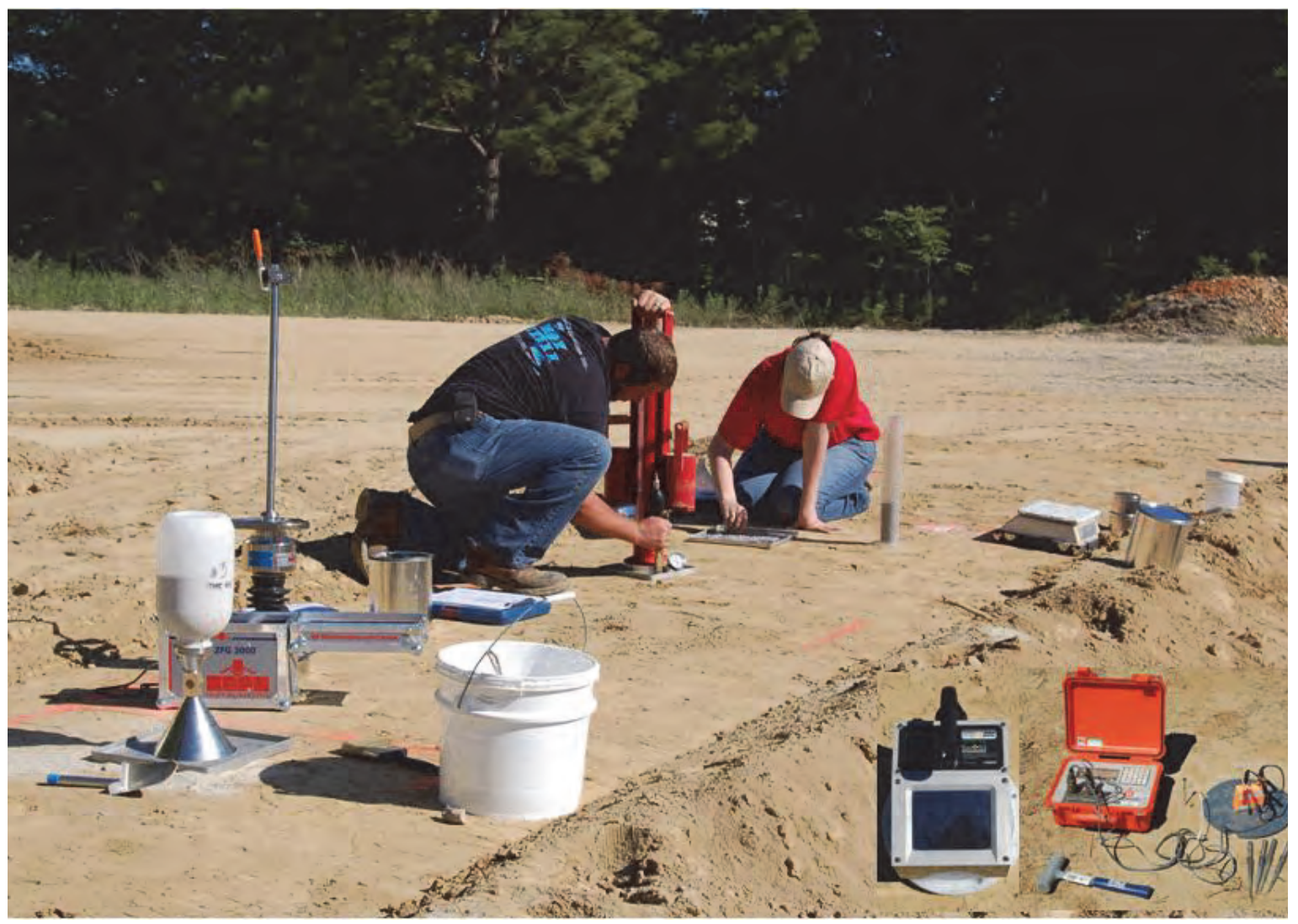


The US Army Engineer Research and Development Center (ERDC) solves the nation's toughest engineering and environmental challenges. ERDC develops innovative solutions in civil and military engineering, geospatial sciences, water resources, and environmental sciences for the Army, the Department of Defense, civilian agencies, and our nation's public good. Find out more at www.erdc.usace.army.mil.

To search for other technical reports published by ERDC, visit the ERDC online library at http://acwc.sdp.sirsi.net/client/default. 


\section{Non-Nuclear Alternatives to Monitoring Moisture-Density Response in Soils}

Ernest S. Berney IV, Mariely Mejías-Santiago, and James D. Kyzar

Geotechnical and Structures Laboratory

U.S. Army Engineer Research and Development Center 3909 Halls Ferry Road

Vicksburg, MS 39180-6199

Final report

Approved for public release; distribution is unlimited. 


\section{Abstract}

During the period May-August 2010, researchers of the U.S. Army Engineer Research and Development Center in Vicksburg, MS, tested the effectiveness of various devices to determine the dry density, or modulus, of soils for horizontal construction. These tests were conducted to determine a usable alternative to the soil nuclear density gauge. The accuracy and precision of the different testing devices were compared to the density values obtained from the soil nuclear density gauge. The devices and techniques that were tested are grouped into four broad families: nuclear, electrical, volume replacement, and modulus-based. The nuclear device was the nuclear density gauge that was included for comparison purposes. Electrical devices that were tested were the electrical density gauge, the moisture + density indicator, and the soil density gauge. Volume replacement densitydetermining techniques; were the sand cone, the steel shot, and the water balloon tests. Modulus-based devices were two different lightweight deflectometers, a dynamic cone penetrometer, the Clegg Hammer, and the GeoGauge. This investigation consisted of full-scale construction of seven soils representing a range of materials encountered in operational construction activities. Soils ranged from fine-grained silts and clays to coarsegrained gravels and crushed limestone. The test results indicated that the soil density gauge corrected with a sand cone density measurement, demonstrated the optimal combination of precision and accuracy compared to the nuclear density gauge.

Results of the tests are presented and include (a) comparisons of the dry densities of the various devices to the reported dry densities of the nuclear gauge, (b) ranking of the density devices according to agreement with the nuclear density gauge, and (c) field results of modulus-based devices. Results will be used to provide further guidance for selection of appropriate devices for field determination of soil density.

DISCLAIMER: The contents of this report are not to be used for advertising, publication, or promotional purposes. Citation of trade names does not constitute an official endorsement or approval of the use of such commercial products. All product names and trademarks cited are the property of their respective owners. The findings of this report are not to be construed as an official Department of the Army position unless so designated by other authorized documents. 


\section{Contents}

Abstract...................................................................................................................................... if

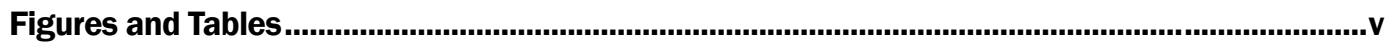

Preface ................................................................................................................................................ vii

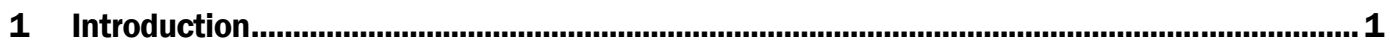

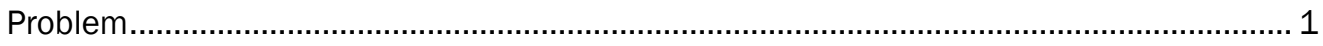

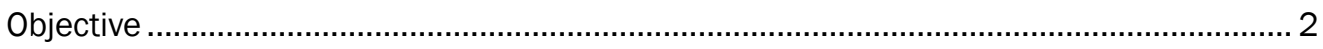

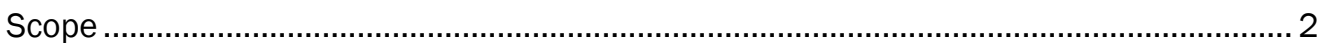

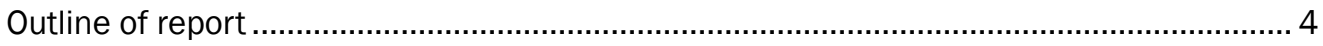

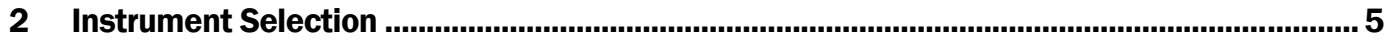

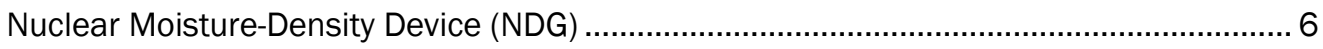

Electrical moisture-density devices ........................................................................ 6

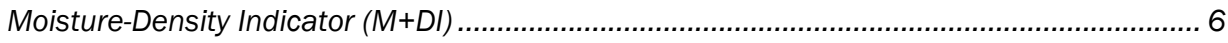

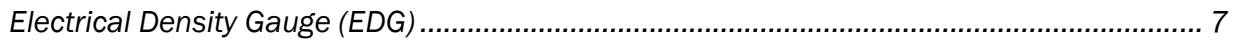

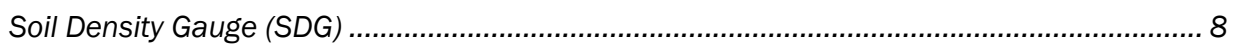

Stiffness/strength devices ..................................................................................... 10

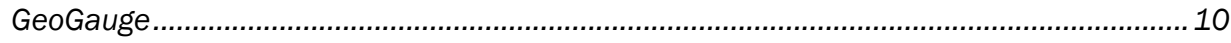

Dynatest Lightweight Deflectometer (D-LWD) ................................................................ 11

Zorn Lightweight Deflectometer (Z-LWD)....................................................................... 12

Clegg Impact Soil Tester/Hammer.............................................................................. 13

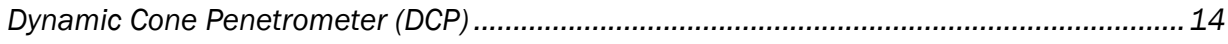

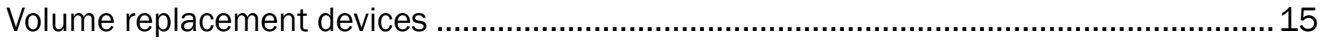

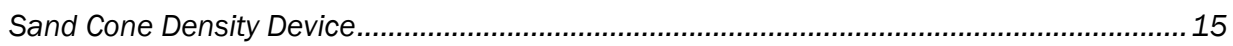

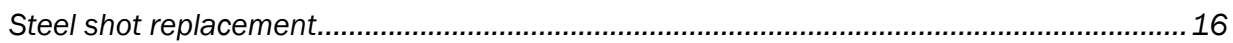

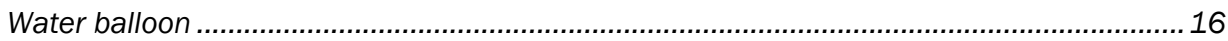

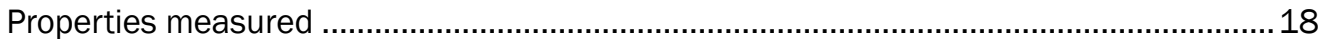

Electrical moisture-density devices ................................................................................ 18

Stiffness/strength devices ............................................................................................. 18

Volume replacement devices .......................................................................................... 19

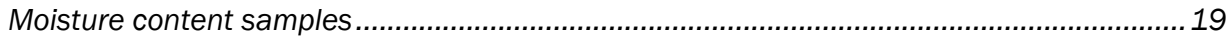

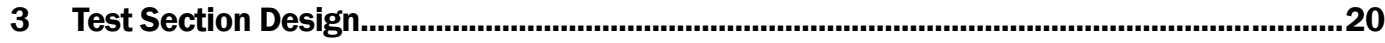

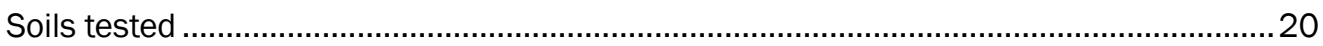

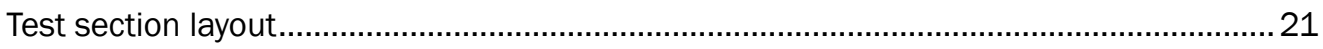

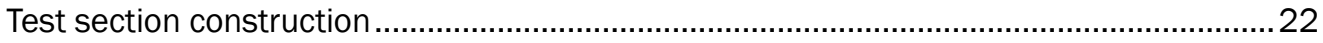

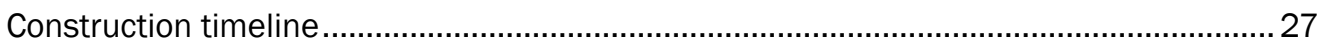

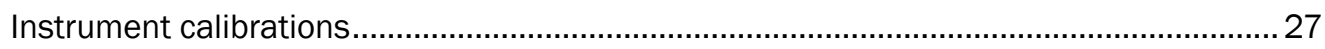

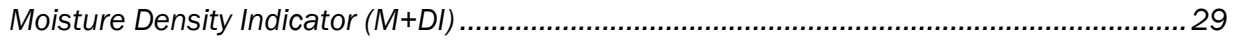

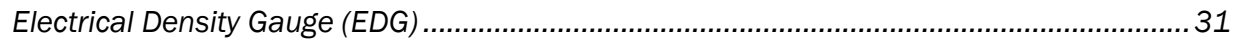

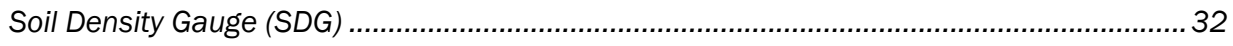




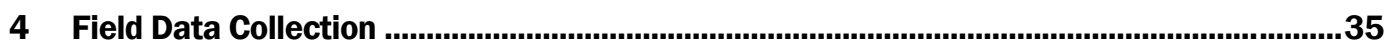

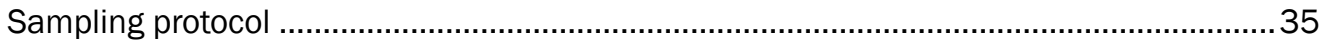

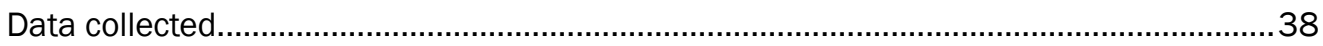

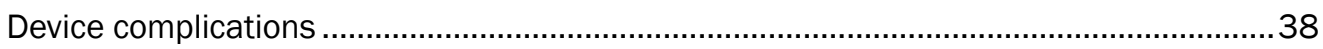

$5 \quad$ Analysis of Field Data ...................................................................................................43

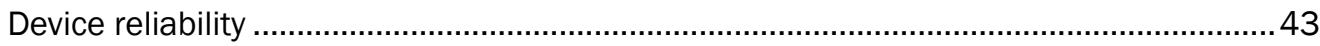

Details of device rejection based on errors .....................................................................43

Accuracy of stiffness/strength devices ......................................................................45

Accuracy of electrical/volume replacement devices.................................................. 47

Summary of device performance ................................................................................ 51

Soil Density Gauge versus Electrical Density Gauge....................................................... 51

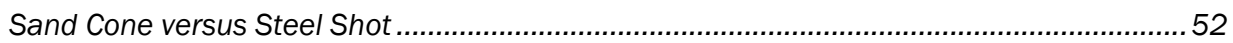

6 Conclusions and Recommendations ..............................................................................53

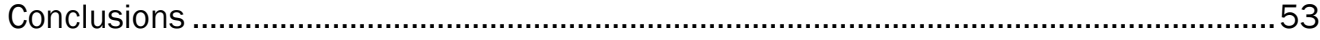

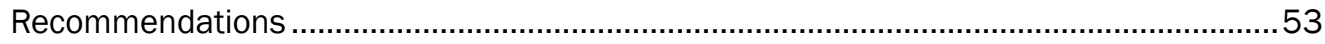

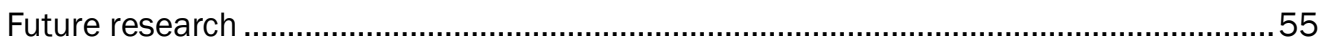

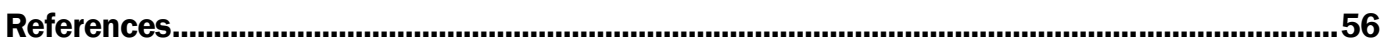

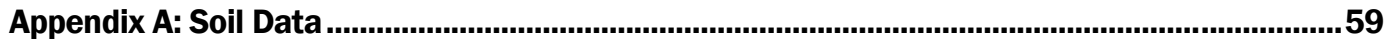

Appendix B: Modulus Based Data .....................................................................................73

Appendix C: Data Spread for Each Device .......................................................................................76

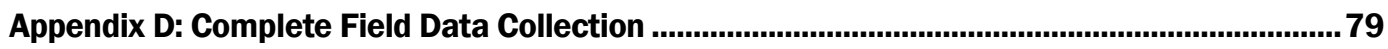

Report Documentation Page 


\section{Figures and Tables}

\section{Figures}

Figure 1. Nuclear density gauge (Model 3430) with sand used for seating.

Figure 2. Moisture-density Indicator (M + DI) MDI-2000. Handheld PDA used for data collection.

Figure 3. Electrical Density Gauge (EDG), Model H-4114C.3F........................................................ 9

Figure 4. TransTech soil density gauge (SDG 200) and cross-sectional view of operation................ 10

Figure 5. Soil Density Gauge clover pattern for surface placement................................................. 10

Figure 6. Humboldt GeoGauge H-4140. .................................................................................. 11

Figure 7. Dynatest Lightweight Deflectometer (D-LWD) requiring laptop and hardwire

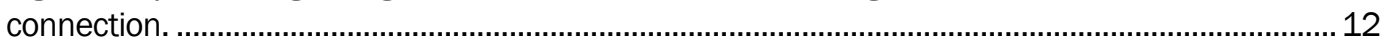

Figure 8. Zorn Lightweight Deflectometer with attached data logger. ............................................ 13

Figure 9. Clegg Hammer with attached data logger. ..................................................................... 14

Figure 10. Dynamic Cone Penetrometer (single and dual mass used)......................................... 15

Figure 11. Sand Cone Density apparatus and accessories.......................................................... 16

Figure 12. Steel shot replacement kit................................................................................... 17

Figure 13. Humboldt Voluvessel (water balloon) and hanging weights.......................................... 17

Figure 14. Overall site layout of soil test items............................................................................ 22

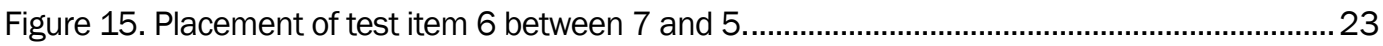

Figure 16. Front-end loader and hydroseeder used in preparing soils for compaction.....................23

Figure 17. Placement of loose GP-GM soil prior to compaction with front-end loader. ..................... 24

Figure 18. Leveling of loose GP-GM material prior to compaction with bulldozer. ............................ 24

Figure 19. Caterpillar CS-443E vibratory roller used in soil compaction on SP-SM soil. Note

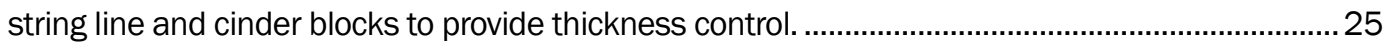

Figure 20. 7-Tire Ingram Rubber Tire Roller used in $\mathrm{CH}$ compaction.............................................25

Figure 21. Wetting surface of lift 3 of test item 3 (ML-3) using hydroseeder. ................................. 26

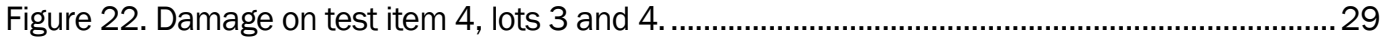

Figure 23. Moisture-Density approximations for calibrating the $\mathrm{M}+\mathrm{DI}$ device.................................30

Figure 24. Illustration of laboratory versus ERDC field calibration for EDG.....................................32

Figure 25. Low moisture-low density calibration pad for EDG on ML-1 (left) and $\mathrm{CH}$ (right).............32

Figure 26. Layout of sampling locations for each soil test item. .......................................................36

Figure 27. Locations of sampling areas on GP-GM test section. .......................................................36

Figure 28. Collecting soil sample for moisture content determination............................................... 37

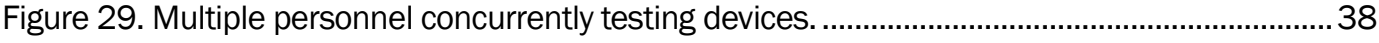

Figure 30. Dry density correlation between DCP and NDG..........................................................46

Figure 31. Dry Density comparison between ZFW and NDG. ......................................................... 46

Figure 32. Flowchart for density device rankings. ...................................................................... 47

Figure 33. Average spread value overall ranking. ……....................................................................... 50 
Figure 34. Maximum-minimum spread value overall ranking.................................................... 51

\section{Tables}

Table 1. A list of studied devices, and the data returned by each device.......................................... 5

Table 2. Summary of soil properties selected for testing................................................................. 20

Table 3. Construction timeline for 7 soil test items........................................................................... 28

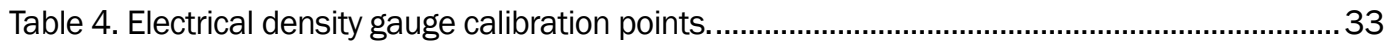

Table 5. Dry density offsets for SDG calibration....................................................................... 34

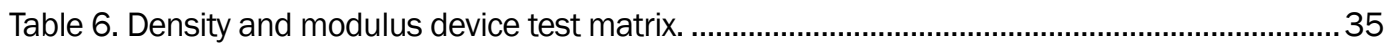

Table 7. Approximate time and personnel breakdown for each tested device...................................37

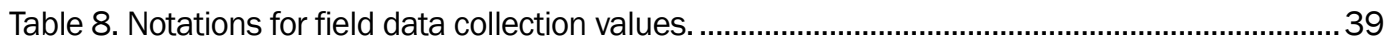

Table 9. Summary of field data by soil, device, coverage level, and section.....................................40

Table 10. Percent data rejection for all instruments and all soil types. ............................................4

Table 11. Average spread (AVGSpread) values for each device type............................................... 49

Table 12. Max-Min spread values for each device type. ................................................................... 49

Table 13. Ranking of devices based on average spread value. ........................................................49

Table 14. Ranking of devices based on max-min spread value. ......................................................50 


\section{Preface}

This report was prepared by the U.S. Army Engineer Research and Development Center (ERDC). J eb Tingle, ERDC Geotechnical and Structures Laboratory (GSL), was the program manager of the U.S. Air Force Non-Nuclear Density project.

The principal investigator for this study was Dr. Ernest S. Berney IV, Airfields and Pavements Branch (APB), Engineering Systems and Materials Division (ESMD), GSL. He was assisted in preparation of this report by Mariely Mejías-Santiago, ESMD, GSL. Other ERDC personnel who assisted in this research effort included J ay F. Rowland, Chase T. Bradley, Louis W. Mason, and Davon S. Mims, of APB; Carla Roig-Silva, Ashley R. Manning, and Evelyn Villanueva, Geotechnical Engineering and Geosciences Branch (GEGB), Geosciences and Structures Division (GSD), GSL; Lawrence O. Oyelami, Concrete Materials Branch (CMB), ESMD, GSL; and Dennis J . Beausoliel, Elizabeth A. McDevitt, and Roberto D. Lamanilao of Bevilacqua Research Corporation.

Dr. Gary L. Anderton was Chief, APB; Dr. Monte L. Pearson was Chief, GEGB; Chris M. Moore was Chief, CMB; Dr. Larry N. Lynch was Chief, ESMD; Bartley P. Durst was Chief, GSD; Dr. William P. Grogan was Deputy Director, GSL; and Dr. David W. Pittman was Director, GSL.

COL Kevin J . Wilson was the Commander of ERDC. Dr. J effery P. Holland was the Director.

Recommended changes for improving this publication in content and/ or format should be submitted on DA Form 2028 (Recommended Changes to Publications and Blank Forms) and forwarded to Headquarters, U.S. Army Corps of Engineers, ATTN: CECW-EWS, Kingman Building, Room 321, 7701 Telegraph Road, Alexandria, VA 22315. 


\section{Introduction}

\section{Problem}

The soil density resulting from the compactive effort applied during soil construction has been established as the primary indicator of the strength and performance of the constructed layer. The currently accepted "best" method of ensuring adequate soil strength design is the constant sampling of moisture content and dry density throughout the construction process. This quality control (QC) activity is most commonly and expediently conducted using a nuclear density gauge (NDG) or sand cone (SC) for density and an NDG or laboratory oven for moisture content determination. The soil density measured with the nuclear density gauge, however, requires recurring verification against another standard test such as the SC density test. Because of potential health, environmental, and safety hazards, the Nuclear Regulatory Commission requires tight controls for transport, storage, monitoring and disposal of these devices, a manpower demand undesirable in a modern, mobile military. Commercial alternatives to the NDG; therefore, are being sought. The absence of military guidance, however, directs the engineer to proper device selection, usage, and limitations; devices that may not provide the required QC needed for construction may be acquired at a considerable expense.

Because of the regulatory and safety burden required for using the NDG, various agencies tasked with QC for horizontal construction, including the Federal Highway Administration and several state departments of transportation (DOTs), investigated available alternatives to the NDG. These investigations identified several types of devices that can be used to measure soil density for QC. The types of devices that generally return a soil density, are as follows: nuclear, volume replacement, and electrical based. Additionally, devices returning a modulus-based reading have been used, but the conversion between soil modulus and density proves to be quite difficult without significant information about the soil of interest.

In addition to measurement of soil density, moisture content is of critical importance to determine compliance with design specifications. A companion study performed alongside the present study determined suitable moisture content devices to replace the soil nuclear density gauge (Berney, Kyzar, and Oyelami 2011). 
Several large-scale investigations into alternative devices for soil QC were recently performed. These compared results using volume replacement (Sebesta et al. 2006; Rathje et al. 2006) and electrical methods (Brown 2007) result in using the NDG. Many other investigations were performed to develop modulus-based devices for QC applications (Crovetti 2002; Mooney et al. 2008; Rathje et al. 2006; Tehrani and Meehan 2010). Often, these investigations are funded by an individual state DOT, with data collection focused on the native soils of the sponsoring state. While many of these devices are able to characterize well the soil of interest, typically a subgrade material, the results do not provide correlations beyond the soil of interest (Rathje et al. 2006). The current study, therefore, is sought to cover a broad range of soil types to encompass a wider variety of construction scenarios.

Volume replacement techniques for density determination are useful due to the lack of calibration required. These techniques, however, are not truly non-destructive because a hole must be created to determine the volume of removed soil. Both the sand cone and the water balloon density tests have American Society for Testing and Materials (ASTM) certification as density methods. Recently, devices based on measuring electrical properties of the soil have emerged (Gamache et al. 2009 and Freeman et al. 2010). These new technologies, most with already accepted ASTM standards, include Time Domain Reflectometery (TDR) and Dielectrics (DI). Many of these technologies are already being fielded by DOTs across the nation. These devices are able to return density in the field without the regulatory burden imposed by use of the nuclear gauge. Soil physical data, however, must be determined to properly calibrate these electronic methods.

\section{Objective}

The U.S. Air Force, along with the U.S. Army Engineer Research and Development Center (ERDC), sought to identify a technology that could effectively measure soil density in the field without the use of a nuclear source (an NDG) or a standard laboratory oven. The research effort entailed evaluation of a wide range of commercially available technologies that could serve as expedient, non-nuclear alternatives for measuring density during construction.

\section{Scope}

The work began with the procurement of several common and emerging devices commercially available for use in identifying soil density in the 
field. The main categories of devices providing soil density are nuclear, volume replacement, and electrical. The nuclear density gauge (NDG) represents the nuclear methods. The sand cone, the water balloon, and the steel shot density tests represent volume replacement tests. Electrical density devices are the Humboldt electrical density gauge, the DurhamGeo moisture + density indicator, and the TransTech soil density gauge. Identification of the desired set of devices to be tested was based on their frequency of mention in research publications and ready availability in the commercial market.

This investigation tested not only the density devices but also the modulusbased devices. These devices include the lightweight deflectometer, the Clegg Hammer, the GeoGauge, and the Dynamic Cone Penetrometer. As stated earlier, the relationship between soil modulus and compliance with density specifications was difficult without a comprehensive soil model; hence, this report includes only the field data for these devices.

To evaluate the regional effectiveness of each device, tests were conducted on seven distinct soil types that covered both fine-grained soils (clays and silts) and coarse-grained soils (sands and gravels) typical of those found in a variety of soil construction scenarios. Each device was tested for each soil at increasing levels of compaction to determine the sensitivity of each device to increase in compaction. All techniques were compared to the results obtained using an NDG, the current military standard for field QC/ QA.

Correlations between measured soil densities were made to:

- Determine the accuracy and precision of various commercially available non-nuclear density devices.

- Determine the ability to prescribe methods for measuring compliance with construction density specifications using commercially available non-nuclear density devices.

- Provide written guidance as to both the suitability of the test devices for QC/ QA in contingency operations and the proper utilization criteria for these devices.

The most promising device(s) will be further explored to refine correlations between device output and achievement of the desired moisture-density state. 


\section{Outline of report}

This report describes the research in the following sequence:

1. Description of operation and use of the selected technologies.

2. Description of the soils selected for study and construction of the field test site.

3. Execution of the field study.

4. Summary of the field study data.

5. Analysis procedures to down-select devices for recommendation for field use and/or future study. 


\section{Instrument Selection}

A literature review was conducted to identify commercially available nonnuclear moisture-density measurement devices that could be readily procured by the military as a suitable replacement for the NDG. A total of eleven devices were identified: three based on electrical methods, three based on volume replacement methods, and five based on stiffness/ strength methods. Twelve devices, including the NDG, were used throughout the evaluation process, as shown in Table 1, each measuring a different set of field soil properties. Density performance of each device was compared to the NDG, the replacement device of interest. Moisture content of the soil was determined by the reference standard oven drying method.

Table 1. A list of studied devices, and the data returned by each device.

\begin{tabular}{|l|l|l|l|}
\hline Device Group/Device Name & $\begin{array}{l}\text { Wet } \\
\text { Density }\end{array}$ & $\begin{array}{l}\text { Moisture } \\
\text { Content }\end{array}$ & Modulus \\
\hline Troxler Nuclear Density Gauge & $\mathrm{X}$ & $\mathrm{X}$ & \\
\hline Electrical Devices & & & \\
\hline Geo-Durham Moisture Density Indicator & $\mathrm{X}$ & $\mathrm{X}$ & \\
\hline Humboldt Electronic Density Gauge & $\mathrm{X}$ & $\mathrm{X}$ & \\
\hline TransTech Soil Density Gauge & $\mathrm{X}$ & $\mathrm{X}$ & \\
\hline Volume Replacement Devices & & & \\
\hline Sand Cone Density & $\mathrm{X}$ & & \\
\hline Steel Shot Replacement & $\mathrm{X}$ & & \\
\hline Water Balloon & $\mathrm{X}$ & & \\
\hline Stiffness/Strength Devices & & & \\
\hline Dynatest Lightweight Falling Deflectometer & & & $\mathrm{X}$ \\
\hline Zorn Lightweight Falling Deflectometer & & & $\mathrm{X}$ \\
\hline Humboldt GeoGauge & & & $\mathrm{X}$ \\
\hline Dynamic Cone Penetrometer* & & & $\mathrm{X}$ \\
\hline Clegg Impact Soil Tester * & & & $\mathrm{X}$ \\
\hline
\end{tabular}

*Dynamic Cone Penetrometer returns blows per length.

**Clegg Impact Soil Tester, returns a calibrated impact value, not a standard modulus

This report does not discuss in detail the concern of rapidly measuring soil moisture in the field. A companion study was undertaken to evaluate techniques to obtain expedient and accurate soil moisture content in the field; the results of which are published in Berney et al., 2011. That study 
included the electrical devices in the present study along with devices designed specifically for soil drying.

The following sections provide functional overviews of the moisturedensity devices and brief descriptions of the theories behind their operation. Specifics concerning the devices' operational theories can be found in their associated ASTM or commercial documentation as listed in the references found in each section.

\section{Nuclear Moisture-Density Device (NDG)}

The Troxler Roadreader ${ }^{\mathrm{TM}}$ nuclear moisture density gauge, Model 3430 (NDG, Figure 1), used emissions from radioactive materials to determine wet density and moisture content of a material. To determine wet density, gamma radiation from a cesium source, $\mathrm{Cs}^{137}$, is emitted into the material of interest. The gamma radiation is then either scattered or reflected by the test material. A detector on the gauge determines the amount of radiation reflected, which is then related to the wet density of the soil. The gauge also uses a neutron source, $\mathrm{Am}^{241}$, to determine the moisture content of the test material. Since the emitted neutrons react with the hydrogen in water, the detector senses neutrons reflected to the gauge. The percentage of neutrons reflected is then related to the water content of the soil (Mooney et al. 2008).

The NDG was used according to ASTM D6938 (2010) with a rod driven six inches into the ground to obtain moisture content and wet density. Wet density is a very reliable measurement from the NDG with more variability associated with the measured moisture content. A soil sample was therefore taken at each test location to obtain oven dry moisture contents per ASTM D2216 (2010) to calculate the field dry density. Sand was used as a leveling material on roughened surfaces such as crushed limestone and cracked clay.

\section{Electrical moisture-density devices}

\section{Moisture-Density Indicator (M+DI)}

The Durham-Geo Moisture-Density Indicator (M + DI), Model MDI-2000, uses Time Domain Reflectometry (TDR), to determine the wet density and moisture content of a material. The TDR works by generating an electromagnetic step pulse through four metal spikes driven into the test material. 


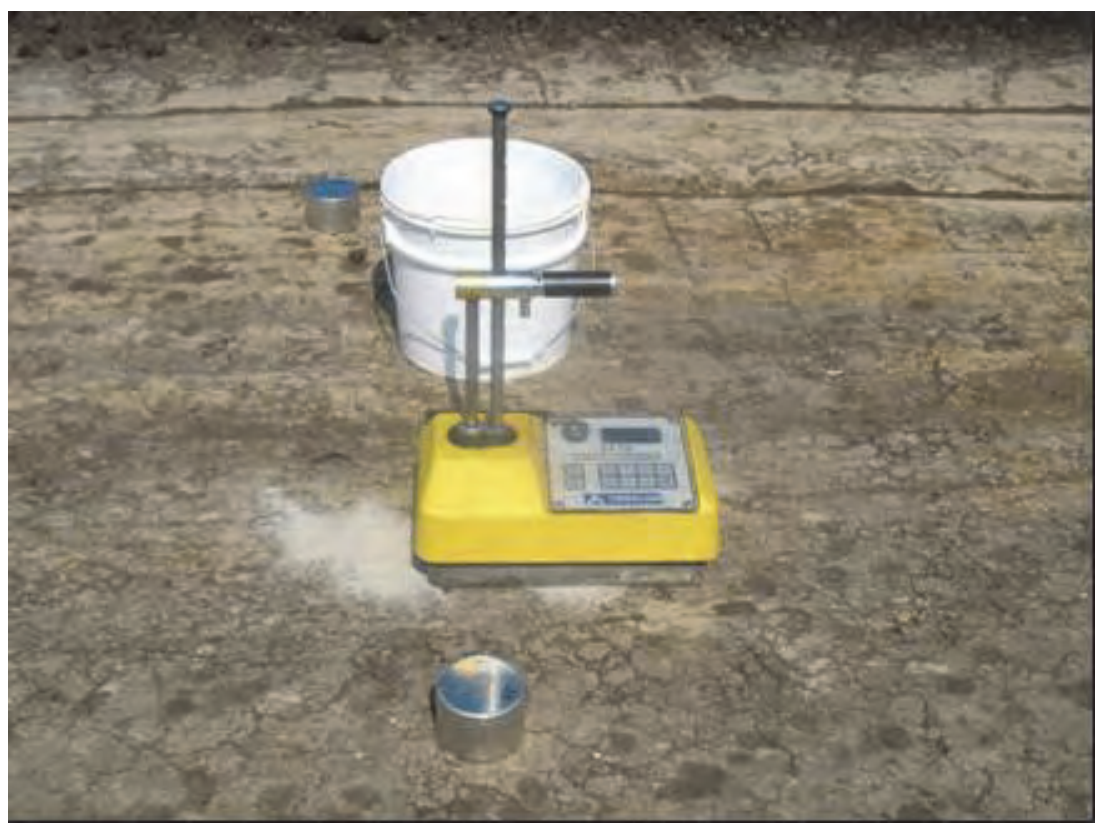

Figure 1. Nuclear density gauge (Model 3430) with sand used for seating.

The spikes are arranged in a specific geometry set by the use of a template. The voltage signal returned through the spikes is analyzed by a personal digital assistant (PDA), using proprietary algorithms to determine the dielectric constant and bulk electrical conductivity of the test material. The analysis software uses these two values to estimate the wet density and moisture content of the soil (Brown 2007).

The M + DI were used according to ASTM D6780 (2010). In the design of a supplied template, four metal spikes were driven with a hammer into the ground. The template was removed after all spikes were emplaced at the appropriate depth. An external temperature probe was then inserted into the nearby soil outside the four-spike configuration. The coaxial head unit was placed on the four spikes, and the readings commenced. The electrical readings were correlated to calibration data selected based on soil type from an internal database. The soil temperature was input, data was collected, and soil density and moisture content values were generated. If during the course of data collection an over-limit error occurred, all spikes were removed and reinserted into an alternate test location. The $\mathrm{M}+\mathrm{DI}$, is shown in operation in Figure 2.

\section{Electrical Density Gauge (EDG)}

The Humboldt Electrical Density Gauge (EDG), Model H-4114C.3F, uses high radio frequency energy transmitted into the material to measure the 


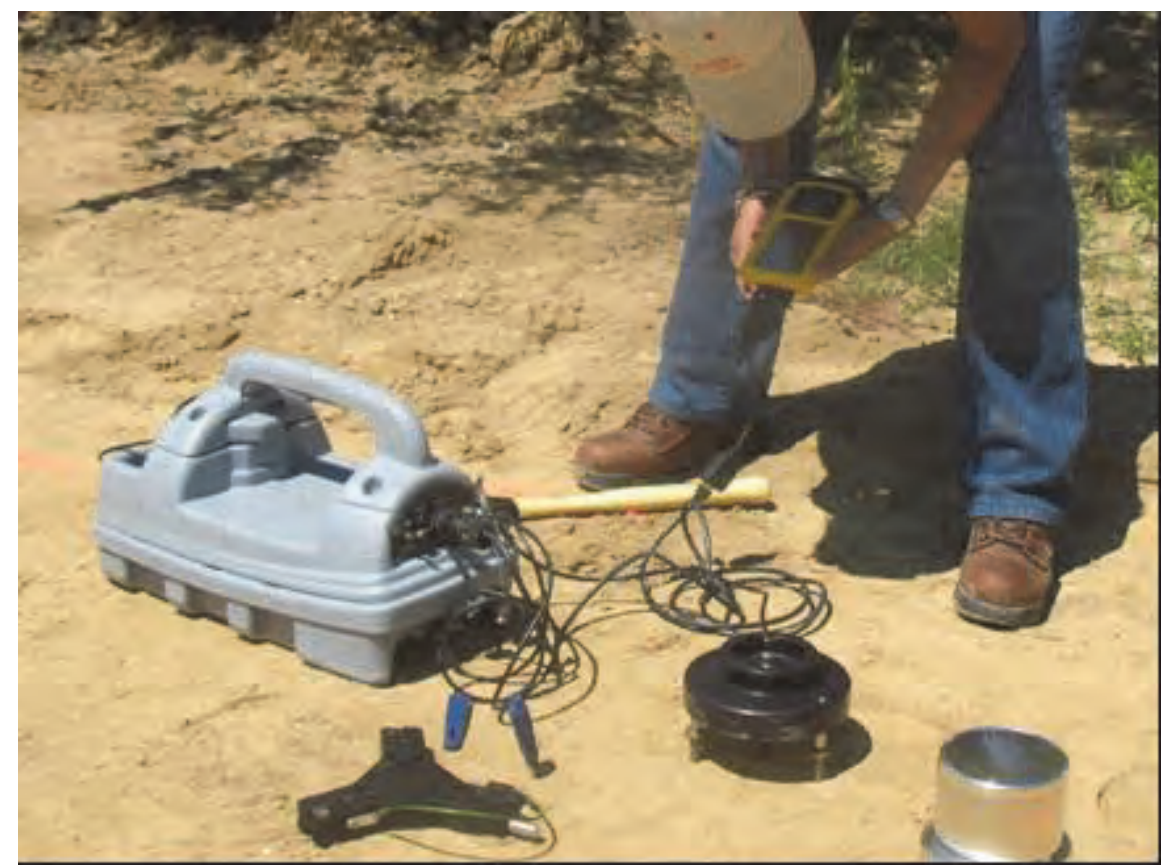

Figure 2. Moisture-density Indicator (M + DI) MDI-2000. Handheld PDA used for data collection.

density and moisture content. The device transmits the radio frequency energy through tapered darts driven into the soil in a specific geometry. After the device analyzes the radio frequency transmitted through the soil to produce a soil dielectric constant, the software calculates resistance (Rs) and capacitance (Cs), the quotient Cs/ Rs, and real impedance (Zs). The EDG then converts these values into density (using Zs) and moisture content (using Cs/ Rs) by using calibration from a known soil model. The soil model is built by taking readings of the given soil at different moisture and density combinations to determine dielectric constants for each combination. The model effectively bounds the analysis of the field data (Brown 2007).

The EDG was used according to ASTM D7698 (2010) by driving the four $150 \mathrm{~mm}$ metal darts into the ground, using the supplied template.

Alligator clips connected to the data acquisition unit were then attached to opposing darts, and a reading was taken. Then the clips were reversed, and another reading was taken. These steps were repeated for the other pair of opposing darts. The EDG is shown in Figure 3.

\section{Soil Density Gauge (SDG)}

The TransTech Soil Density Gauge (SDG) measures density and moisture content of a material by using advanced electrical impedance spectroscopy 


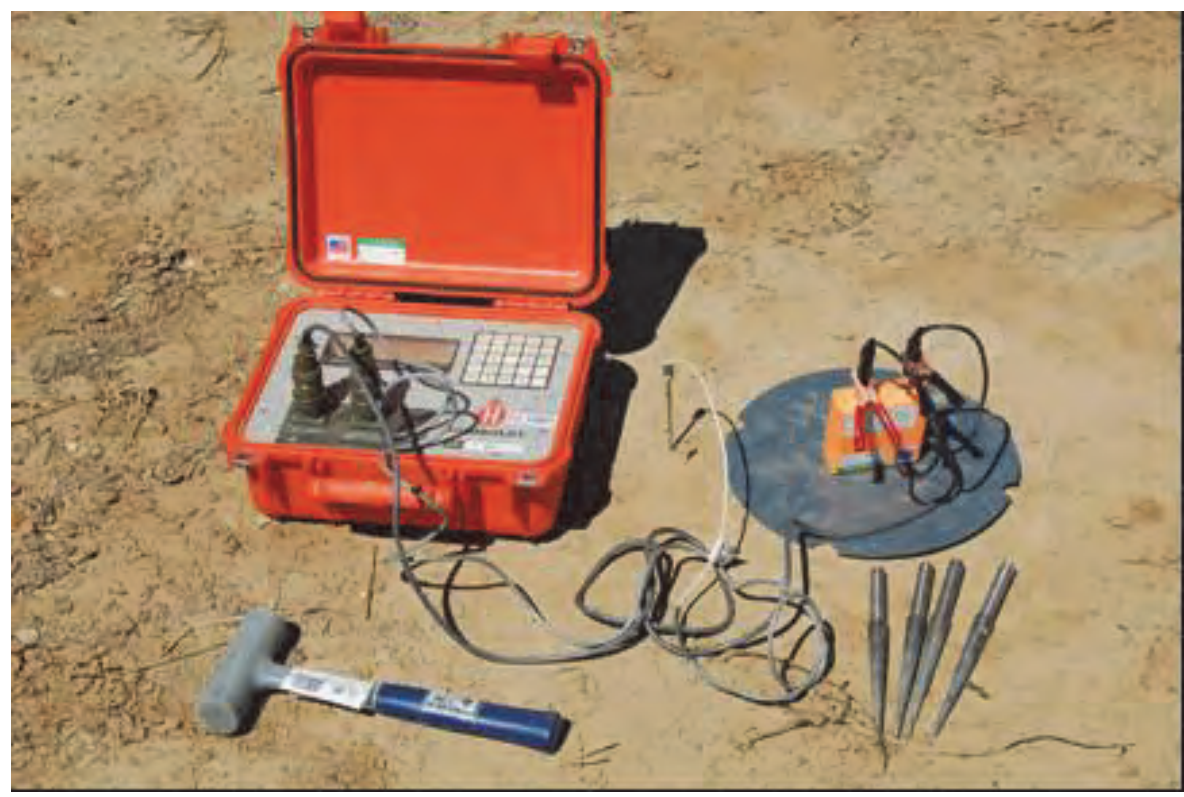

Figure 3. Electrical Density Gauge (EDG), Model H-4114C.3F.

(EIS), which allows for non-contact measurements of soil density and moisture content. As shown in the diagram in Figure 4, the non-contacting sensor in the SDG 200 consists of two rings: a central ring and an outer ring. The central transmit ring injects an electric field into the soil, and the response is received on the outer sensing ring. The density, or compaction level, is measured by the response of the SDG's electrical sensing field to changes in electrical impedance of the material matrix. Since the dielectric constant of air is much lower than that of the other soil constituents, as density/ compaction increases, the combined dielectric constant increases because the percentage of air in the soil matrix decreases. The SDG performs a calculation on the measurement data that enables the device to report the soil's density and moisture content (TransTech Systems, Inc.). A known moisture and density reading on the soil of interest is required as an initial condition from which to calibrate the measured soil density and moisture content values (Gamache et al. 2009).

The SDG was used per the manufacturer's instructions, as an ASTM standard for this device does not exist. The device was placed on the soil, and testing began using the onscreen menu. The device was then moved diagonally about $12 \mathrm{in}$., based on the diagram shown on the device screen. Testing was conducted for each location shown on the screen following this same method, as illustrated in Figure 5. 

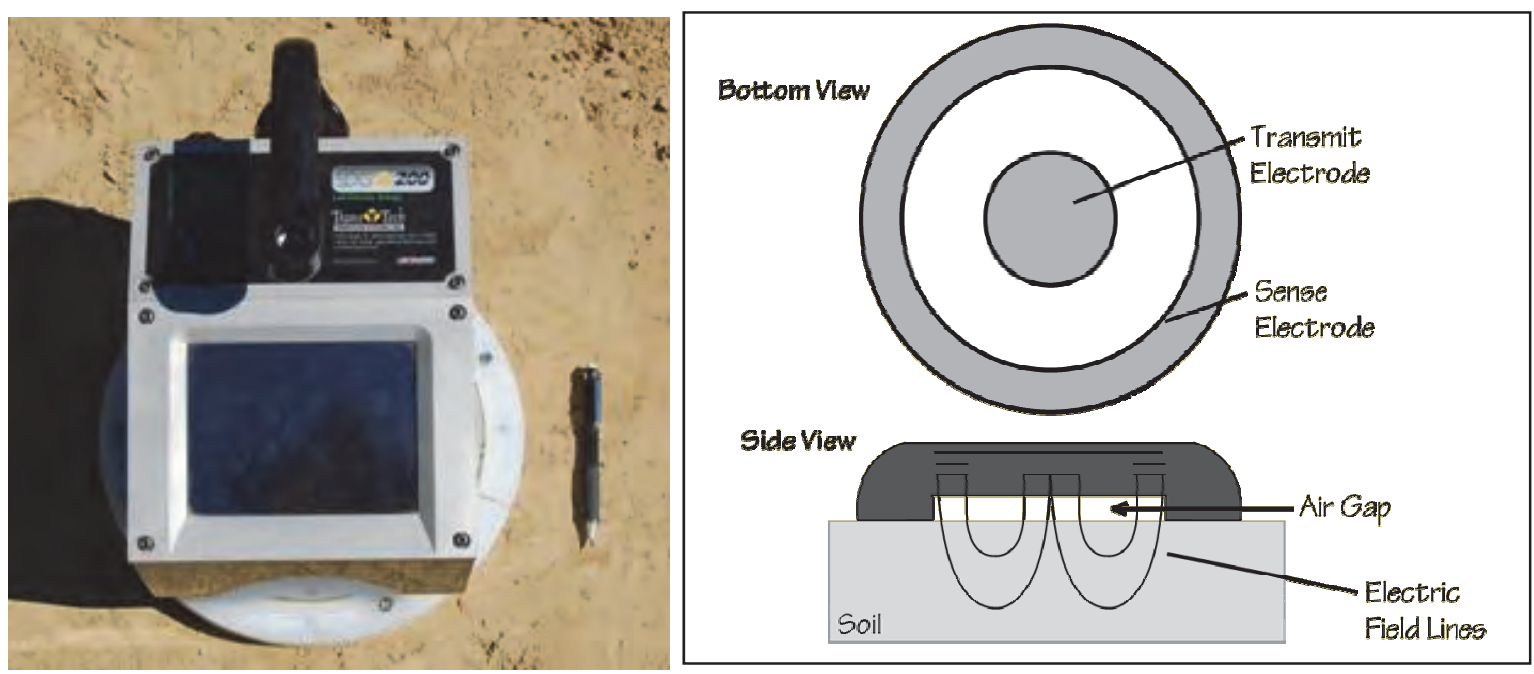

Figure 4. TransTech soil density gauge (SDG 200) and cross-sectional view of operation.

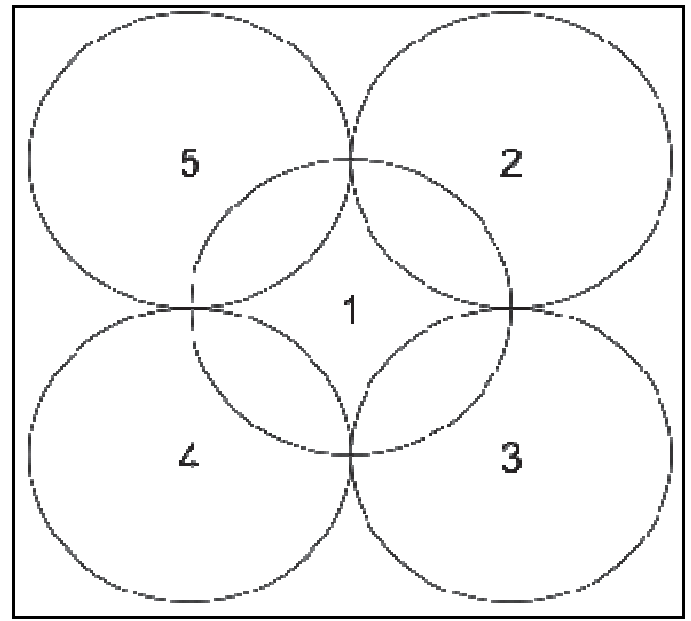

Figure 5. Soil Density Gauge clover pattern for surface placement.

\section{Stiffness/strength devices}

\section{GeoGauge}

The Humboldt GeoGauge is a portable instrument that measures the surface stiffness of a material. The gauge works by applying oscillating torsional displacement on the top of the soil through an annular ring. The device measures the force required and the displacement of the soil at 25 frequencies over a spectrum of 100-196 Hz. The static stiffness of the material is related to the elastic modulus and Poisson's ratio of the soil averaged for each frequency tested. The calculations for soil stiffness assume homogeneous isotropic soils with consistent elasticity (Lenke, McKeen, and Grush 2003). 
The GeoGauge was used according to ASTM D 6758 (2010), and three separate readings were performed. The device was placed on the soil, and the unit was turned $1 / 4$ turn to "seat" the annular ring. If the first reading returned a non-valid reading, sand was used to fill any voids in the surface of the soil. The GeoGauge is shown in Figure 6.

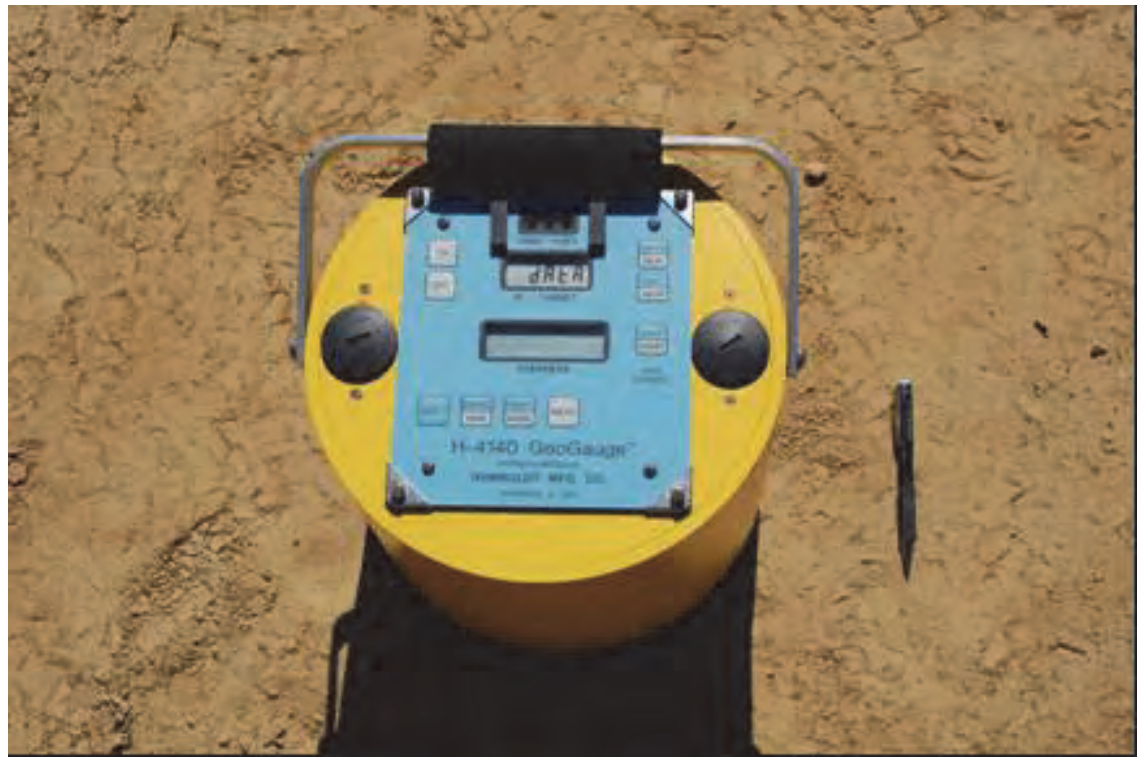

Figure 6. Humboldt GeoGauge H-4140.

\section{Dynatest Lightweight Deflectometer (D-LWD)}

The Dynatest Lightweight Deflectometer (D-LWD), records the in situ elastic modulus of soils by dropping a weight onto a load plate resting on the surface of the soil. The falling weight imparts a load of $9.8 \mathrm{kN}$ for duration of $20 \mathrm{~ms}$ onto the load plate. The load plate acts as a geophone, recording ground movement with sensors located at the bottom of the plate as changes in voltage occur. The D-LWD determines the maximum applied force and maximum displacement, which are then related to soil modulus. Output for the D-LWD is sent through a wireless Bluetooth signal to the supplied PDA or through a wired connection to a laptop computer (Mooney et al. 2008).

The D-LWD was used according to ASTM E2583-07 (2010) with three seating drops followed by three measured drops. The weight was allowed to rebound and come to rest before the next drop began. The device used the supplied 300-mm-diameter plate dropped from varying heights to keep the reading within range of the sensors. Modulus was recorded as the output result, as deflection varied with drop height. The D-LFD is shown in Figure 7. 


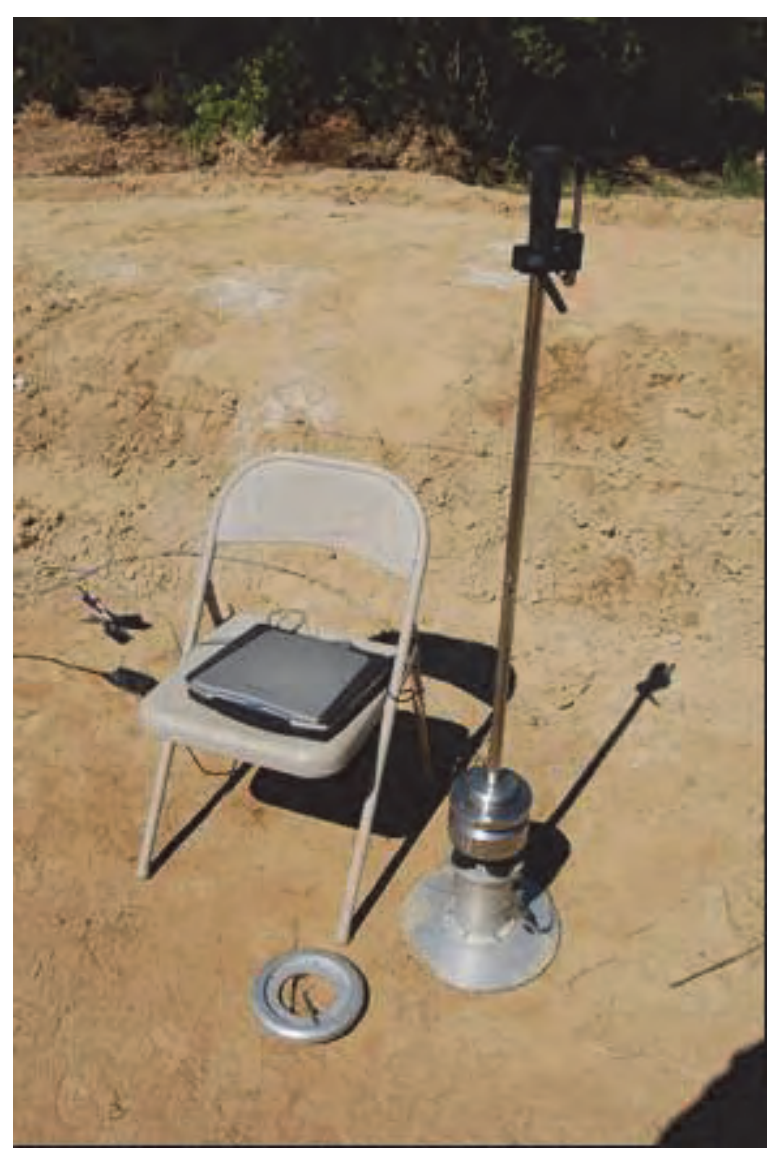

Figure 7. Dynatest Lightweight Deflectometer (D-LWD) requiring laptop and hardwire connection.

\section{Zorn Lightweight Deflectometer (Z-LWD)}

The Zorn Lightweight Deflectometer (Z-LWD) records the in situ elastic modulus of soils by dropping a weight onto a load plate resting on the surface of the soil. The falling weight imparts a load of $7.07 \mathrm{kN}$ for duration of $18+/-2$ ms onto the load plate. The load plate acts as an accelerometer, recording the change in acceleration with sensors located at the top of the plate. The Z-LWD determines the maximum applied force and maximum displacement, which are then related to soil modulus. Output for the Z-LWD is recorded by an external printer (Mooney et al. 2008).

The Z-LWD was used according to ASTM E2583-07 (2010) with three seating drops followed by three measured drops. The falling weight was caught on the rebound after each drop such that the sensors recorded the impact from only one height. The device used the supplied 200-mmdiameter plate dropped from a constant height. The modulus was recorded as the output result, as deflection varied with drop height. The D-LWD is shown in Figure 8. 


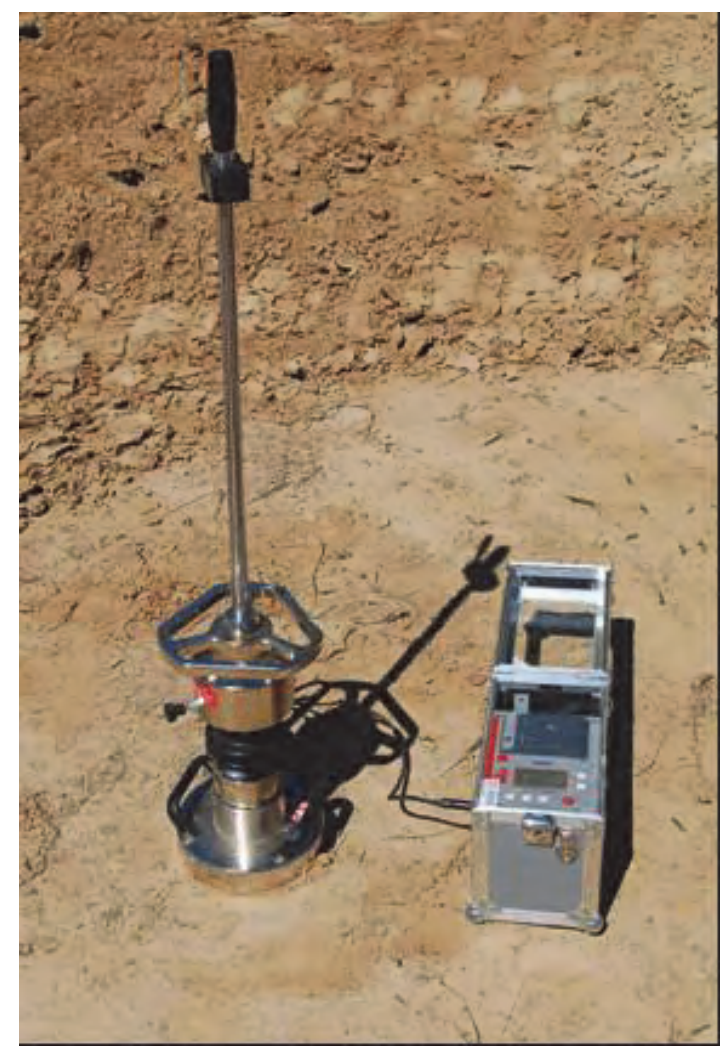

Figure 8. Zorn Lightweight Deflectometer with attached data logger.

\section{Clegg Impact Soil Tester/Hammer}

The Clegg Impact Soil Tester also known as the Clegg Hammer (Clegg) was used according to ASTM D5874-02 (2010) to measure the Clegg Index Value (CIV) of the soil. The CIV is a measure of the soil's stiffness relative to the moisture content and compaction level of the soil. The device works by measuring the deceleration of the weight as it impacts the soil. The CIV is the deceleration measured in micro gravities, with a well-defined proctor curve for a given soil. The impact value can be graphically correlated to a location on a moisture-density curve, given that the moisture content has been measured (Mooney et al. 2008).

The Clegg Hammer in this investigation used a $4.5 \mathrm{~kg}$ hammer with a $45 \mathrm{~cm}$ drop height. Each test consisted of raising the hammer to the specified height and dropping it through the tube. The CIV was recorded, and this process was repeated for a total of four tests. The highest CIV observed was recorded as the impact value for that soil. A version of the Clegg was used early in the exercise with a handheld data recorder; however, the battery in the data reconder failed, and a second Clegg Hammer that had a mounted data recorder was used. The Clegg Hammer is shown in Figure 9. 


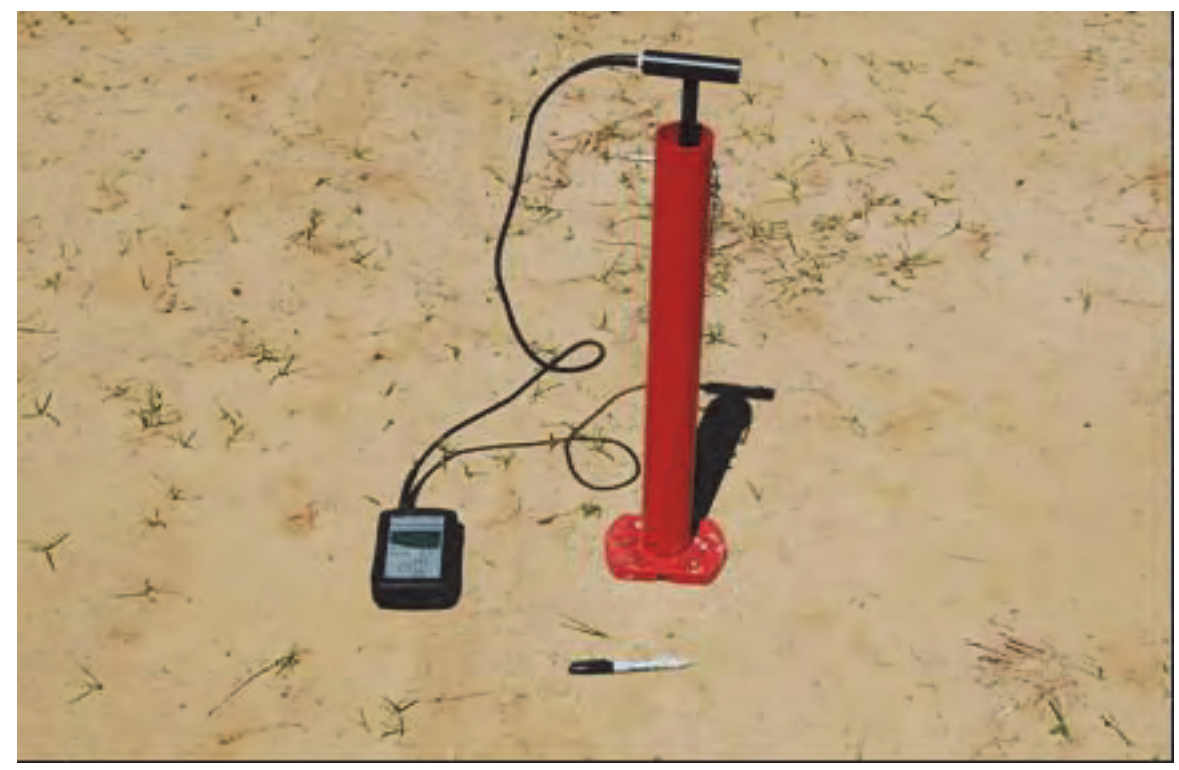

Figure 9. Clegg Hammer with attached data logger.

\section{Dynamic Cone Penetrometer (DCP)}

The Dynamic Cone Penetrometer (DCP) is a common device used to estimate the California Bearing Ratio (CBR), a combined measure of stiffness and soil strength. The device consists of a drive rod with a sliding circular hammer attached, an anvil secured to the drive rod, and a $60^{\circ}-$ $20 \mathrm{~mm}$ cone attached to the end of the drive rod. The hammer is raised to a predetermined height and allowed to drop, impacting the anvil and driving the tip into the ground. The penetrated depth-per-blow is recorded until the rod is driven a specified measure into the soil. Correlations have been developed relating the penetration results from the DCP to CBR, resilient modulus, and friction angle. All these correlations require additional input for the soil in question in addition to the DCP data (J ayawickrama, Amarasiri, and Regino 2000).

The test was conducted according to ATSM D6951-09 (2010). For most of the soil types, a single mass $4.54 \mathrm{~kg}$ ( $10 \mathrm{lb}$ ) hammer was used due to the soft nature of the soil when subjected to only a few roller passes. Except for the densely compacted soil, the dual mass $7.8 \mathrm{~kg}(17.1 \mathrm{lb})$ hammer was used to penetrate stiff compacted surfaces. Blows were measured for every $20 \mathrm{~mm}$ of penetration, and the DCP was inserted into the ground through the entire thickness of the test section and into the subgrade to ensure that all layers were tested. Only blows recorded in the top 6 in. were recorded as an indication of stiffness. Moisture content was taken at the location of each test to normalize stiffness with moisture content variability. The DCP is shown in Figure 10. 


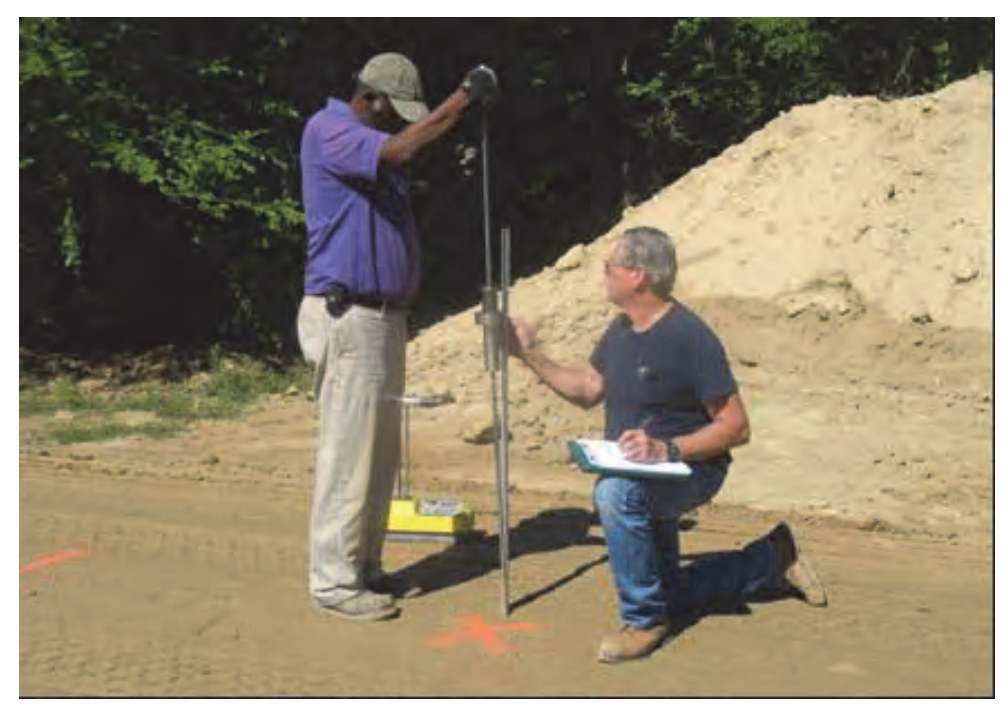

Figure 10. Dynamic Cone Penetrometer (single and dual mass used).

\section{Volume replacement devices}

\section{Sand Cone Density Device}

The sand cone density test (SC) is a volume replacement test that determines the wet density of a soil. Density is determined by the quotient of soil mass removed from a hole divided by the volume of the hole. The volume of the hole created is indirectly measured by the mass of sand used to fill the hole, with the assumption that the sand fills the hole with a known, uniform density (Sebesta et al. 2006).

The sand cone replacement test was conducted according to ASTM D1556 (2010). Clay was used to seal the inner ring of the sand cone plate to minimize sand's being trapped beneath the plate. The uniform sand used was 20-30 Ottawa sand. Four sand cone devices were used during testing to expedite the process, with only two engineers performing sand cone testing throughout the exercise. Each sand cone bottle was water and sand calibrated prior to the start of the exercise, but no further calibration checks were conducted after the testing began. A field scale accurate to $0.5 \mathrm{~g}$ determined the mass of soil and sand. A surface calibration was performed on every hole dug to account for surface variability at each test location. Holes were dug with a diameter slightly smaller than the ring, and a depth of at least 3 - 4 in. for all fine-grained soils and up to $5 \mathrm{in}$. or more for granular materials to produce a representative sample volume. The sand cone density device is shown in Figure 11. The cardboard box pictured, acted as a wind buffer to minimize scale drift during weighing. 


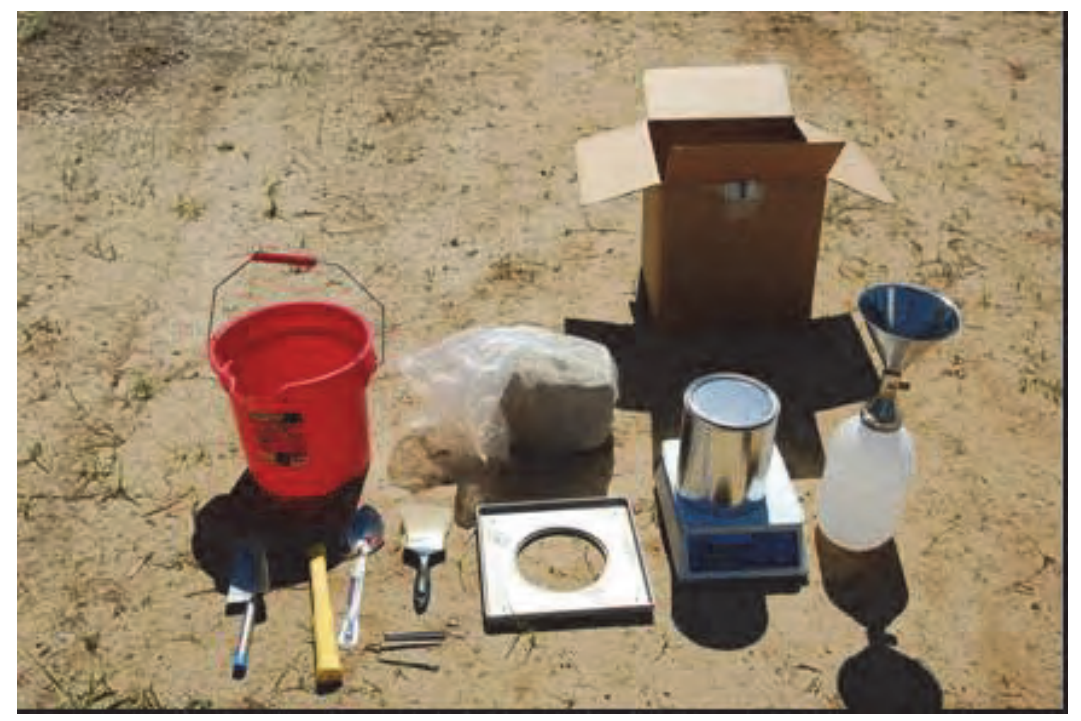

Figure 11. Sand Cone Density apparatus and accessories.

\section{Steel shot replacement}

The steel shot replacement device (SS) was developed by the U.S. Army Corps of Engineers as a volume replacement test for use as an expedient alternative to the SC to measure wet density. Freeman et al. (2010) describes this test in detail. Density is determined by the soil mass removed from a hole divided by the volume of the hole. The procedure is that a hole either four or six inches in diameter is dug and filled with steel shot. A field scale accurate to $0.5 \mathrm{~g}$ determines the soil mass. The steel shot by its nature compacts to the same density independent of drop height or handling. A graduated cylinder, therefore, is filled with steel shot to a known volume, and then the shot is poured into the hole. The volume difference noted in the graduated cylinder is the volume of the hole. For this investigation, no clay was used in sealing the test plate, so it was possible for steel shot to undercut the plate in certain soils. Holes were dug a minimum of 3 - 4 in. deep with a 4-in.-diameter hole opening in fine-grained soils and a 6-in.diameter hole opening for coarse-grained soils. The SS density kit is shown in Figure 12.

\section{Water balloon}

The water balloon density test (WB) is a volume replacement test that determines the wet density of a soil. A Humboldt Voluvessel was selected as the water balloon test device, and the test was conducted per ASTM D2167 (2010). A surface calibration was performed at each test location to account for any surface variability. After the surface calibration, a cylindrical hole was dug 4 - 6 in. into the soil using the metal ring as a guide for the 
diameter. Density was determined by dividing the soil mass removed from the hole by the volume of the hole. The volume of water to fill the hole, bounded by a thin rubber membrane, directly measured the volume of the hole. A portable field scale accurate to $0.5 \mathrm{~g}$ determined the mass of the removed soil. When a membrane ruptured, it was replaced; and a new test hole was dug away from the wet hole location to remove any bias in density caused by the leakage of water into the soil. Hanging weights were added to the apparatus to help prevent uplift of the Voluvessel, and alleviate some of the reaction force required by the operator. The water balloon density device is shown in Figure 13.

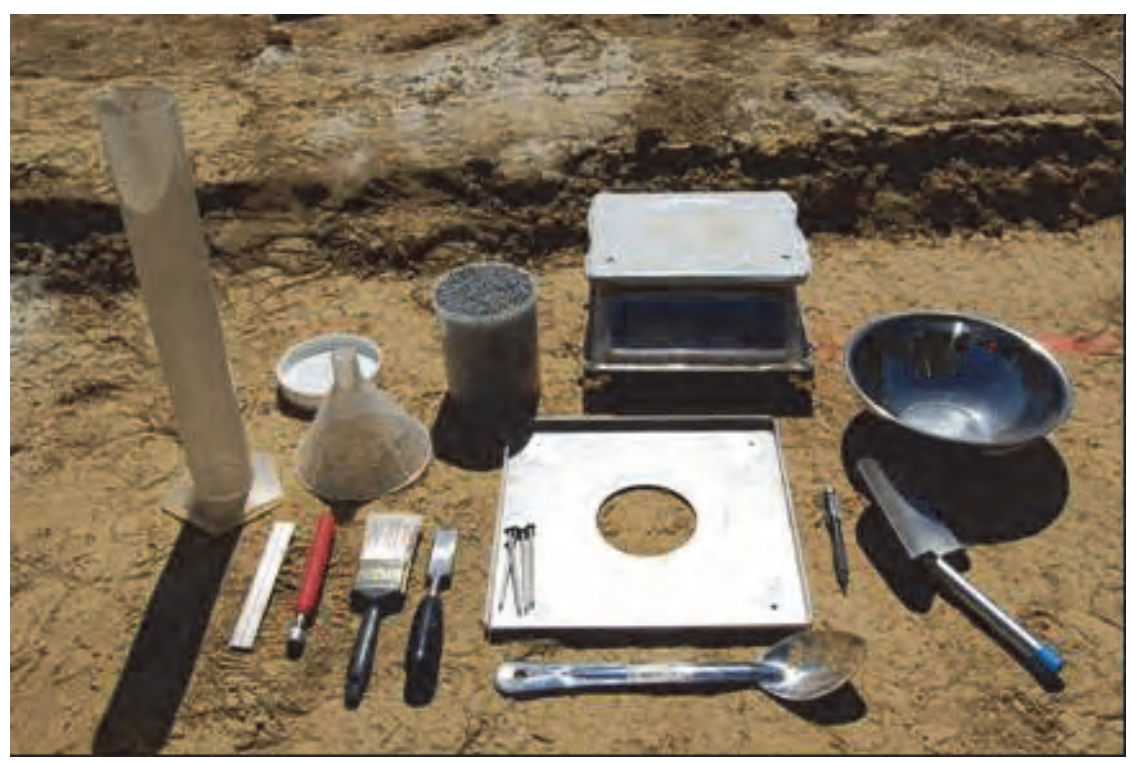

Figure 12. Steel shot replacement kit.

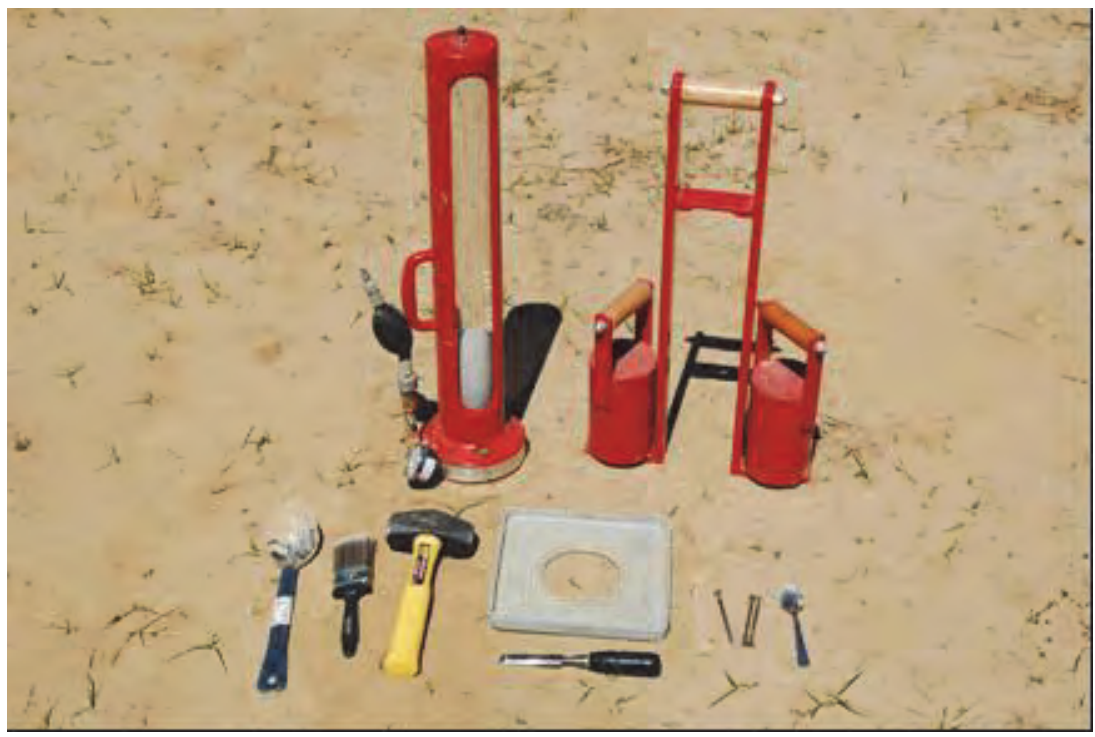

Figure 13. Humboldt Voluvessel (water balloon) and hanging weights. 


\section{Properties measured}

\section{Electrical moisture-density devices}

The EDG and the M+DI, measure electrical resistance between a series of probes embedded in the soil. The resultant resistance is compared to a set of calibrated readings covering the range of field moisture content and wet density expected in the field. The EDG is calibrated from moisture and density field results measured with the nuclear density gauge. The M+DI does not provide for an expedient field calibration; therefore, is calibrated with preset curves based on similar soil types used in the field. The devices return to the user the wet density, dry density, and moisture content of the soil, resulting in a comparative data set to the NDG.

The TransTech SDG computes statistical factors from the frequency sweep generated during its testing to determine the impedance of the soil. This is used to estimate the wet density, gravimetric moisture content, and calculated dry density for each soil.

\section{Stiffness/strength devices}

Each of these instruments provides varying responses in terms of stiffness or strength. The DCP provides a number of hammer drops per depth of penetration. For its analysis a summary total of hammer drops over a nominal 6-in.-depth of penetration is used as the comparative value to the density.

The Clegg Hammer provides a Clegg Index Value (CIV) that corresponds to the acceleration response at the point of impact of the hammer. This CIV value is used as the comparison to density.

The LWD devices provide a deflection measurement of the plate and a back-calculated soil modulus based on an assumed Poisson's ratio. Only the deflection, however, was used as comparative measure to density in this research, as the back-calculated modulus is secondary data output from the devices and dependent on knowledge of the Poisson's ratio.

The GeoGauge provides a modulus (force/ area) and stiffness (force/length), of which the modulus was chosen as the representative output for the device. 


\section{Volume replacement devices}

The SC, SS replacement, and WB all measure the same physical properties of the soil. Each technique measures a weight of wet soil excavated from a hole and uses sand, steel shot, or a water-filled balloon to measure the volume of the excavated hole. Dividing the weight of wet soil by the excavated volume provides a wet density for the soil. A sample of the wet soil is taken to a laboratory where it is dried in an oven to calculate the moisture content. The wet density and the water content are used to obtain the dry density of the soil, resulting in a comparative data set to the NDG.

\section{Moisture content samples}

For all devices tested, a moisture content sample was taken from the top 2-4 in. of the ground surface at the point of each measurement to normalize any changes of behavior with moisture content. The results of the laboratory oven moisture content represent the ASTM reference standard for moisture measurement, and the results were used for a different purpose for each device type:

1. For the electrical devices, the field moisture content allowed an evaluation of the devices' moisture content measurements to the reference standard to be made.

2. For the NDG, the wet density is assumed to be the most accurate measurement. The oven moisture content represents a check against the device's measured moisture and is used to calculate a more accurate dry density at each test location.

3. Because the moisture content can greatly influence soil stiffness/ strength for soil compacted at a constant density, the moisture content was used to normalize device response within the subset of tested instruments to account for this variable.

4. The moisture content was used to assess the dry density of all the volume replacement techniques, as this is a required part of the testing procedure. 


\section{Test Section Design}

\section{Soils tested}

This exercise used seven soil types to approximate typical soils encountered during horizontal construction efforts for which the NDG serves an important role in quality control (QC). Table 2 presents a summary of the soils selected for testing and their associated engineering properties. Tests conducted on each soil include ASTM standard grain size distribution (ASTM C136, 2010) with hydrometer analysis (ASTM D422, 2010) for dissemination of silt and clay fractions, Atterberg limits (ASTM D4318, 2010) including liquid limit (LL) and plastic limit (PL), engineering classification according to the Unified Soil Classification System (USCS), and standard proctor compaction (ASTM D698, 2010) to determine optimum moisture content (OMC) and maximum dry density (MDD). Details of these test results can be found in Appendix A.

Table 2. Summary of soil properties selected for testing.

\begin{tabular}{|c|c|c|c|c|c|c|c|c|c|c|}
\hline & & USCS & \multicolumn{2}{|c|}{ Grain size percent by weight } & \multicolumn{2}{|c|}{ Atterberg Limits } & \multicolumn{2}{|c|}{ Standard Proctor } \\
\cline { 5 - 13 } Item & Descriptor & Class. & Gravel & Sand & Silt & Clay & LL & PL & OMC (\%) & MDD (pcf) \\
\hline 1 & Loess - ML-1 & ML & 1.2 & 11 & 78.4 & 9.4 & NP & NP & 15.8 & 109.5 \\
\hline 2 & ASTM Concrete Sand & SP & 4.9 & 92 & 2.3 & 0.8 & NP & NP & 9.5 & 109 \\
\hline 3 & Sandy Silt - ML-3 & ML & 2.7 & 47 & 43.9 & 6.4 & NP & NP & 10 & 121.8 \\
\hline 4 & Silty Sand w/ Gravel & SM & 29.2 & 45.9 & 21.1 & 3.8 & NP & NP & 7.8 & 129.7 \\
\hline 5 & Sand w/Clay and Gravel & SP-SC & 41.3 & 50.7 & 3.1 & 4.9 & 23 & 13 & 8 & 128.8 \\
\cline { 2 - 12 } & Sand w/Silt and Gravel & SP-SM & 33.8 & 57 & 3.7 & 5.5 & NP & NP & 10.2 & 125.7 \\
\hline 6 & Buckshot Clay & CH & 0 & 4.9 & 18.6 & 76.5 & 73 & 24 & 24.6 & 85.7 \\
\hline 7 & Crushed Limestone & GP-GM & 52.8 & 40.9 & 3.9 & 2.4 & 15 & 12 & 6.8 & 136.3 \\
\hline
\end{tabular}

Of note is that the sandy-silt and silty-sand w/ gravel were manufactured blends of the loess and concrete sand with some washed rounded gravel introduced for the gravel gradation. These manufactured blends were mixed on-site with appropriate proportions of each soil type mixed with a front end loader and a bulldozer on a hardened concrete surface. The desired USCS classifications were those of an SM and a GM, respectively. Because these were not naturally occurring materials segregation occurred during the mixing process. In addition, the crushed limestone ordered from a local aggregate supplier classified as a GP-GM when ideally, a GW or an SW classification was desired. Test Item 5 contained two soils, as a reorder of 
materials occurred during construction and the soil lot properties had changed.

The intent of the selected soils was to provide a spectrum of behaviors necessary to validate instrument response.

1. A series of fine-grained soils that included clay, silt, and sandy-clay/ silt blends, was required to provide soils with high moisture retention to test the ability of devices to distinguish higher moisture contents in determining dry density. These soils tended to have a lower stiffness and tested the sensitivity of the stiffness/ strength devices to capture large deformations.

2. A series of coarse-grained soils that included crushed limestone, silty-sand with gravel, and sand w/ clay and gravel provided large aggregates that could adversely influence probe-based measurement devices. The large aggregate soils also provided stiffer responses to loading the test sensitivity of the stiffness/strength-based measurements over a small deflection range.

3. Mixtures of soils, such as sand w/ clay and gravel and limestone, evaluated calibration techniques used in some electronic devices where both gradation input and Atterberg limit data were necessary to obtain moisture-density relationships.

4. Large aggregate materials provided a challenge to volume replacement methods in which refilling the hole could be compromised by the lack of a smooth carved wall surface in the excavated hole.

5. Soft soils such as loess and concrete sand provided construction platforms where little density change occurred and were sufficiently soft to cause error or over-limit readings in the water balloon and stiffness/ strengthbased devices.

6. Lastly, the soils that were tested comprised a wide range of fines and aggregate content and were soils typical of those used in various horizontal construction activities.

\section{Test section layout}

The seven soil test items were constructed side by side, as shown in Figure 14, according to the dimensions given. The seven test items were constructed individually to facilitate testing of these methods under uniform weather conditions rather than constructed concurrently, allowing some soils to undergo weathering due to rain, heat, etc. The longitudinal dimensions provided enough run that the compactor could achieve a steady 


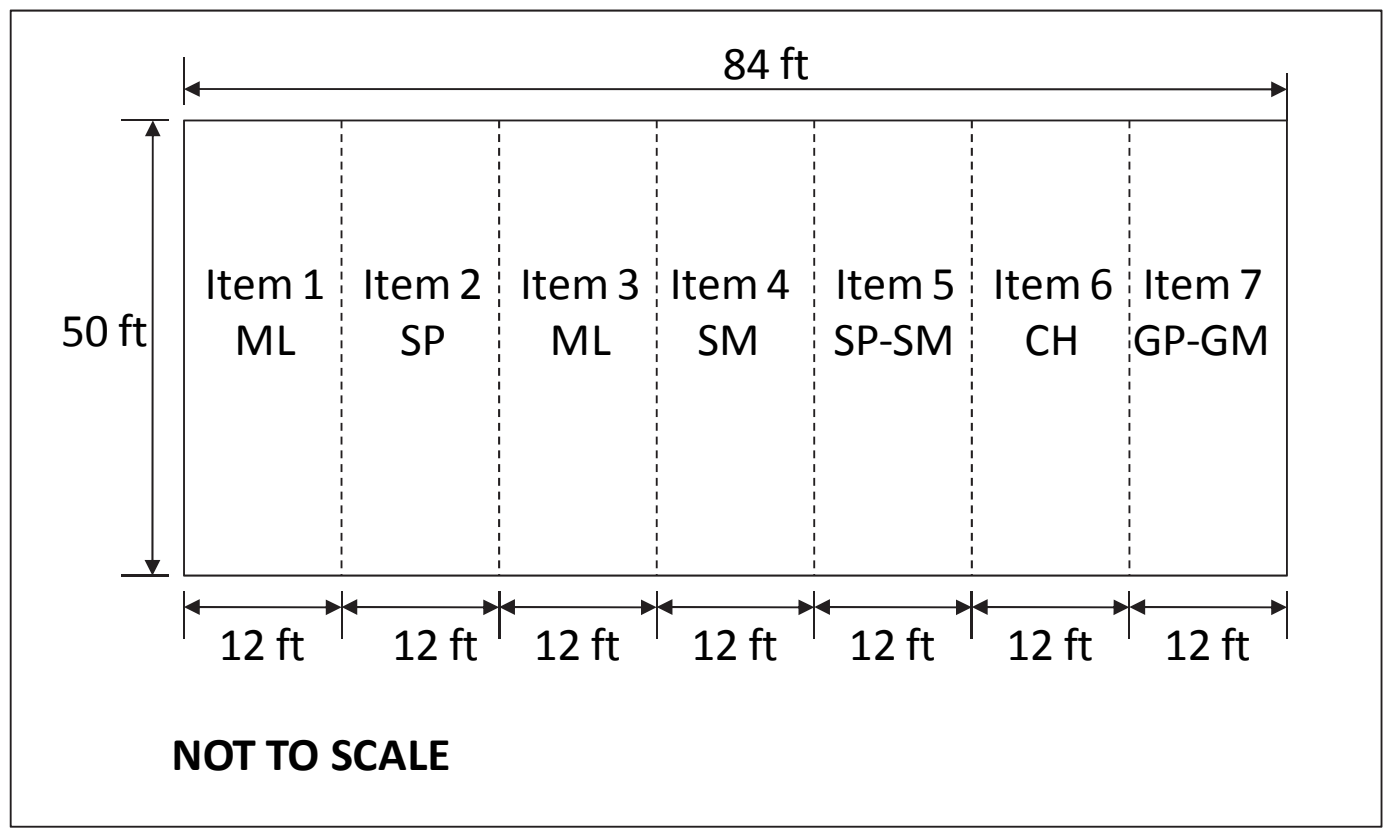

Figure 14. Overall site layout of soil test items.

velocity across the central portion of the test section, providing as much uniform compaction as possible. The first lift placed was approximately two roller widths ( $12 \mathrm{ft}$ ) across to provide a wide enough base to create a top layer at least $6 \mathrm{ft}$ across. The test items were constructed in three 6-in.-thick compacted lifts such that the final test section was 18-in.-thick. This provided a suitable thickness of uniform soil above the natural subgrade to ensure that each instrument's response was not influenced by the subgrade layer's properties.

Test items were built in a staggered format to (1) provide lateral resistance for construction of the softer soils, improving compaction, and (2) to allow construction of subsequent test items simultaneously to testing of previous ones, as shown in Figure 15. Test items were constructed in the following order: 1, 3, 2, 5, 4, 7 and 6.

\section{Test section construction}

Each soil was mixed and prepared on a large concrete surface near the test site. Soil was moisture conditioned using a front-end loader for mixing and a hydroseeder for providing water, as shown in Figure 16. Soils that were a mixture of soil types were blended with a front-end loader. 


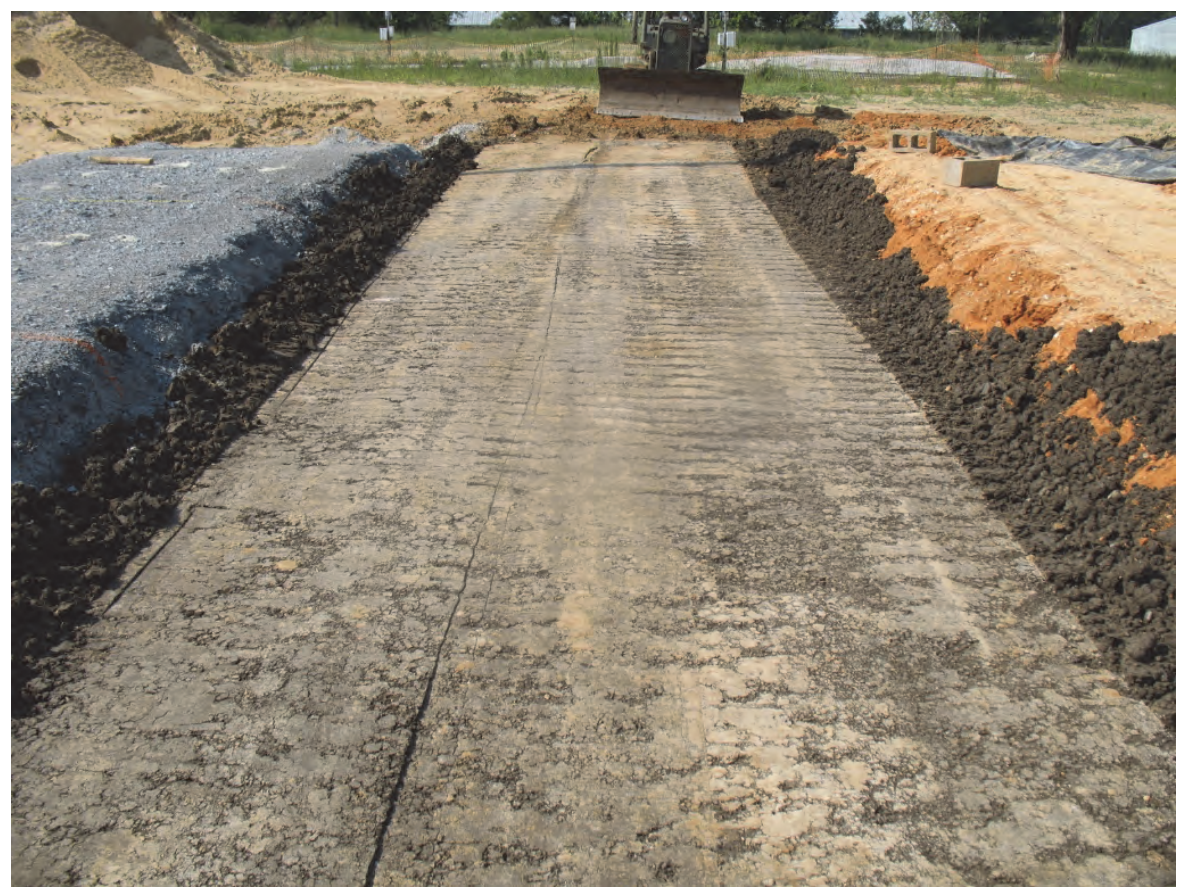

Figure 15. Placement of test item 6 between 7 and 5.
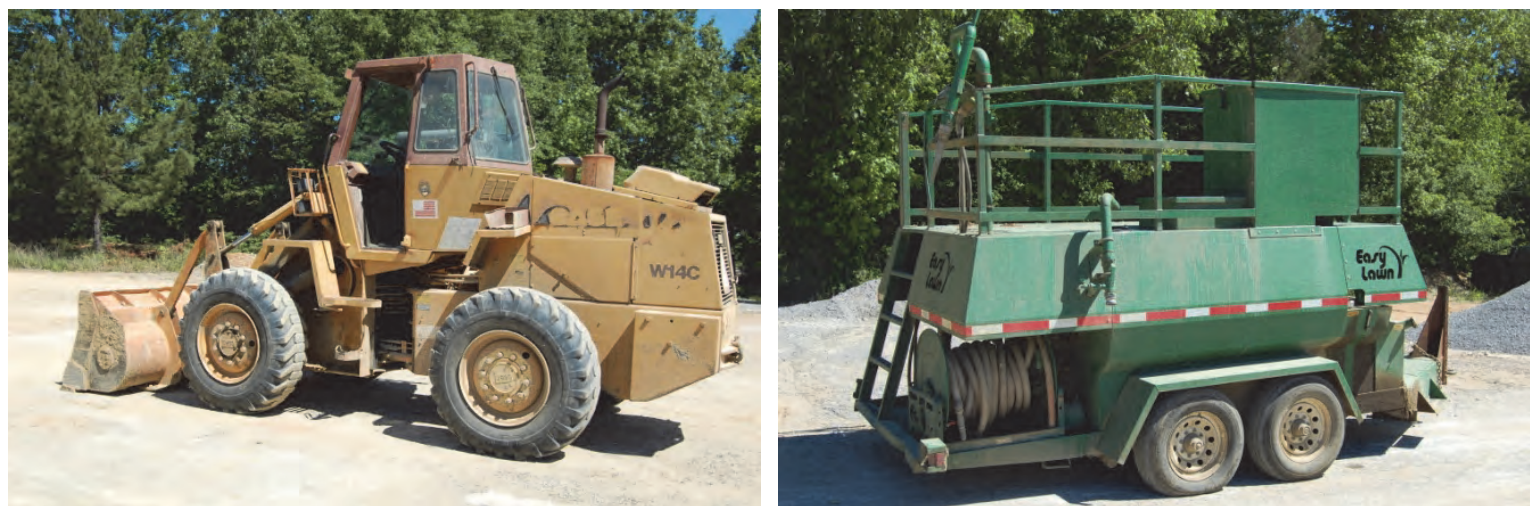

Figure 16. Front-end loader and hydroseeder used in preparing soils for compaction.

The subgrade was graded level prior to placement of the first lift. Each lift was then placed with a front-end loader (Figure 17), and the loose soil was leveled with a bulldozer (Figure 18) to approximately 8-in.-thick prior to being rolled with a compactor. Cinder blocks and string lines were used to ensure a uniform thickness of each lift to achieve a more uniform density across the section, as shown in Figure 19. A Caterpillar CS-443E vibratory roller (gross weight $\sim 15,000 \mathrm{lbs}$ ) was used for all the soils except the Buckshot clay (CH) (test item 7). For the $\mathrm{CH}$, a 7-tire Ingram Rubber Tire Roller (gross weight $\sim 70,000 \mathrm{lbs}$ ), as seen in Figure 20, was used to achieve density and was selected based on performance from extensive field experience at ERDC in preparing this soil. 


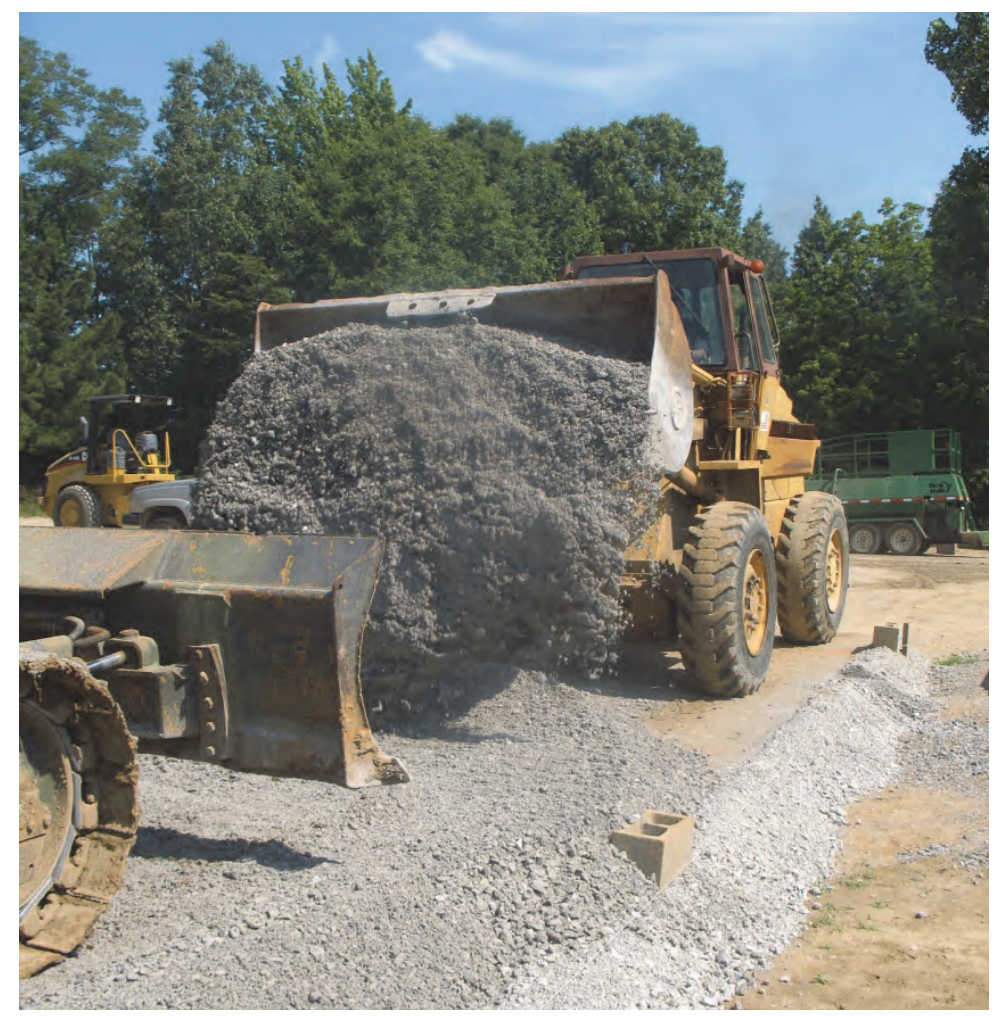

Figure 17. Placement of loose GP-GM soil prior to compaction with front-end loader.

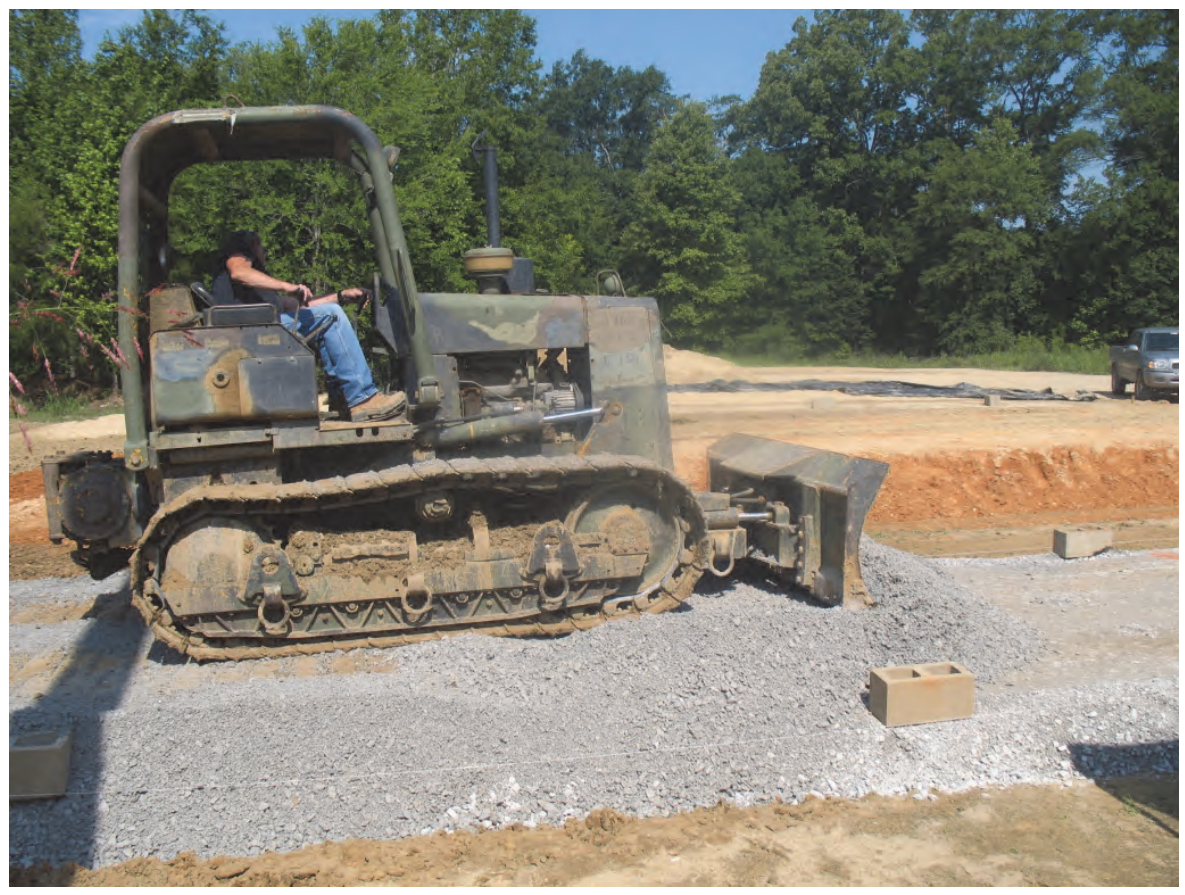

Figure 18. Leveling of loose GP-GM material prior to compaction with bulldozer. 


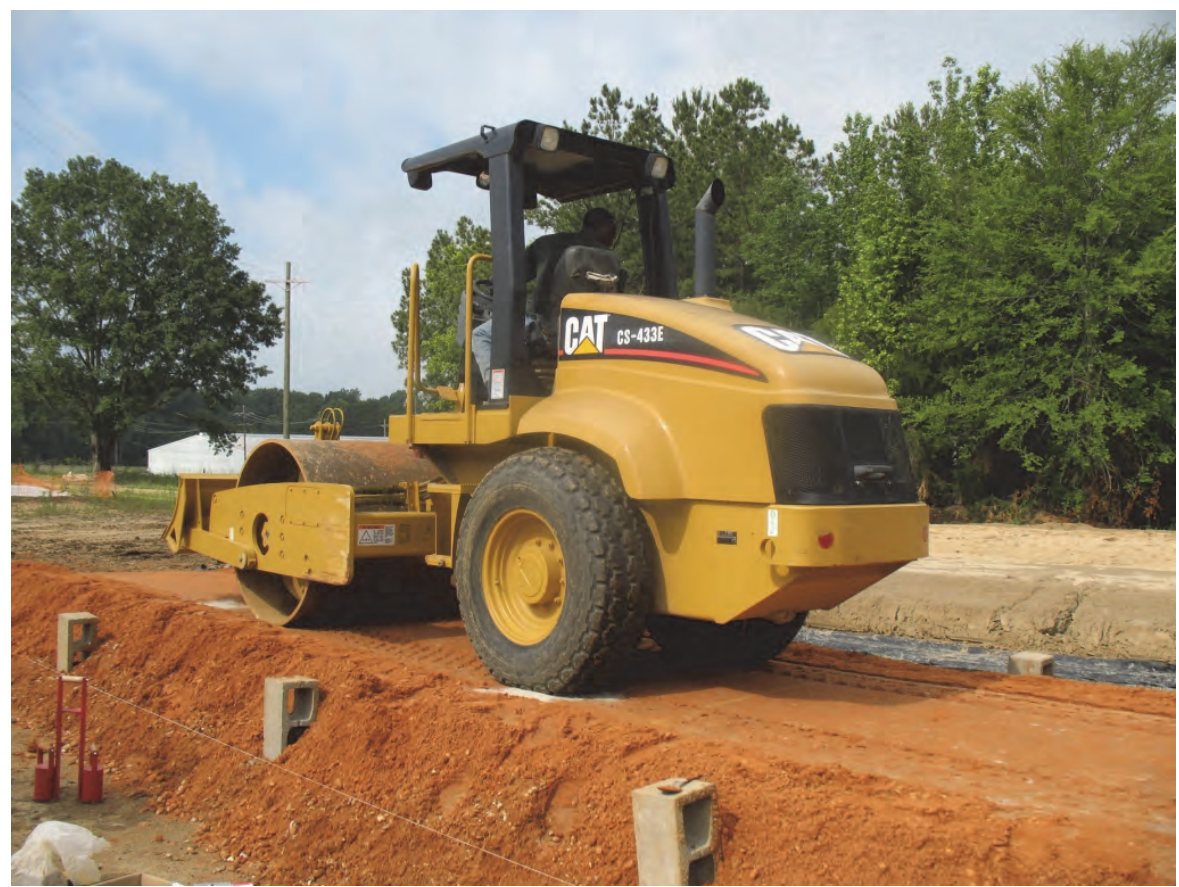

Figure 19. Caterpillar CS-443E vibratory roller used in soil compaction on SP-SM soil. Note string line and cinder blocks to provide thickness control.

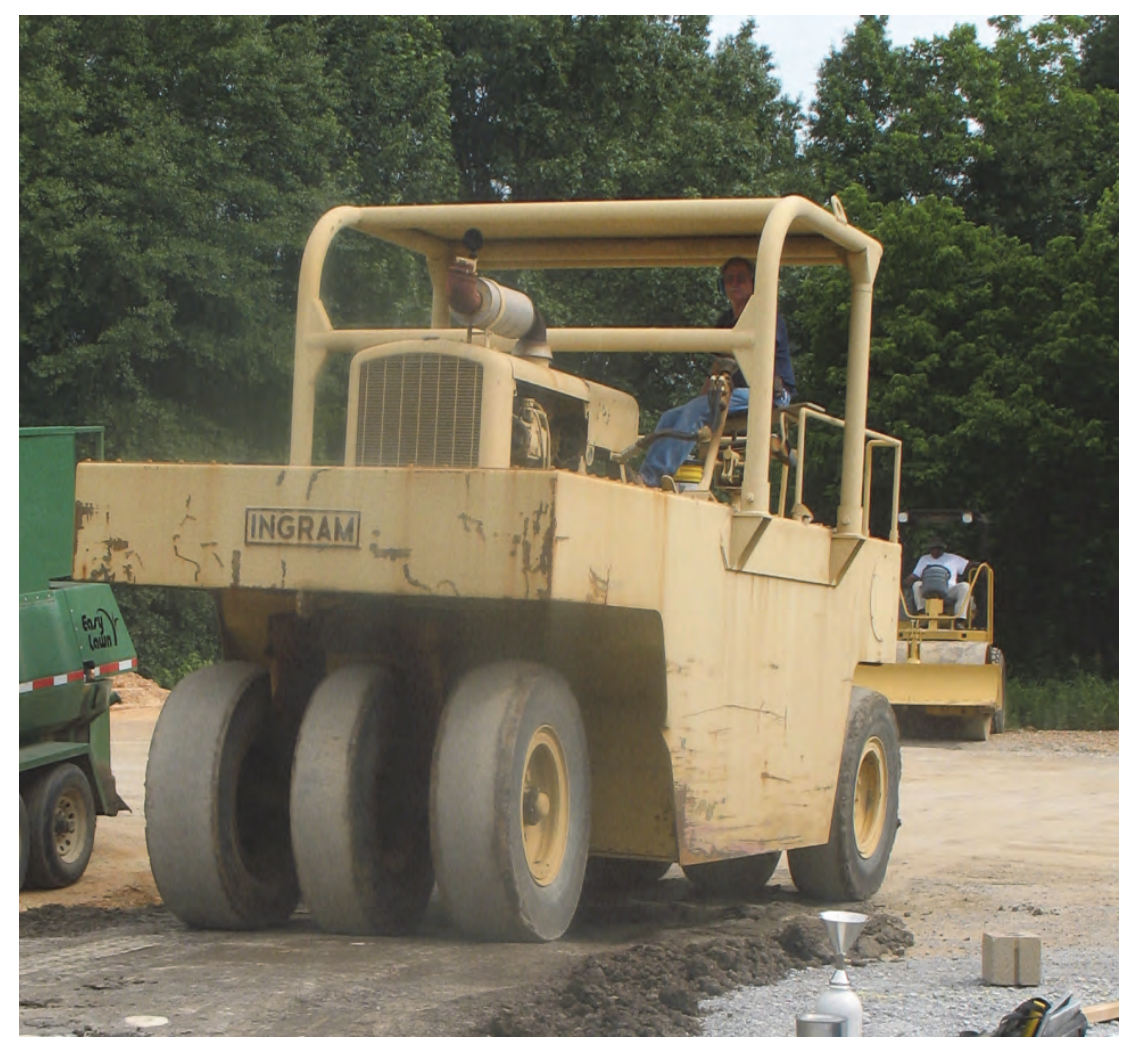

Figure 20. 7-Tire Ingram Rubber Tire Roller used in $\mathrm{CH}$ compaction. 
Each soil test item was constructed in three 6-in.-lifts denoted as lifts 1 (bottom), 2 (middle), and 3 (top). For all soils except the Buckshot clay (CH) material, lifts 1 and 2 were each compacted with eight coverages of the vibratory roller. Coverage is defined as the passing of the roller over the lift to one end and rolling backwards to the other end. The second lift was placed using smaller overall widths to achieve stable side-slopes, again using eight compactor coverages on each lift. On the third (top) lift, a single coverage was performed across the entire width of the section and tested as coverage number 1 . The $\mathrm{CH}$ material was compacted with the rubber-tired roller with an additional coverage from the vibratory compactor to provide a smooth surface prior to each test sequence. Vibration was used on all test sections except test item 4 , where excessive moisture was being returned to the surface under vibration. The SDG and NDG devices were tested after the final coverage on lifts 1 and 2 to determine the characteristics of the base material beneath lift 3. The DCP and NDG were performed on the underlying subgrade. A large plastic tarp was placed over the top of each section to retain compaction moisture when the section was to be left until a subsequent day to test.

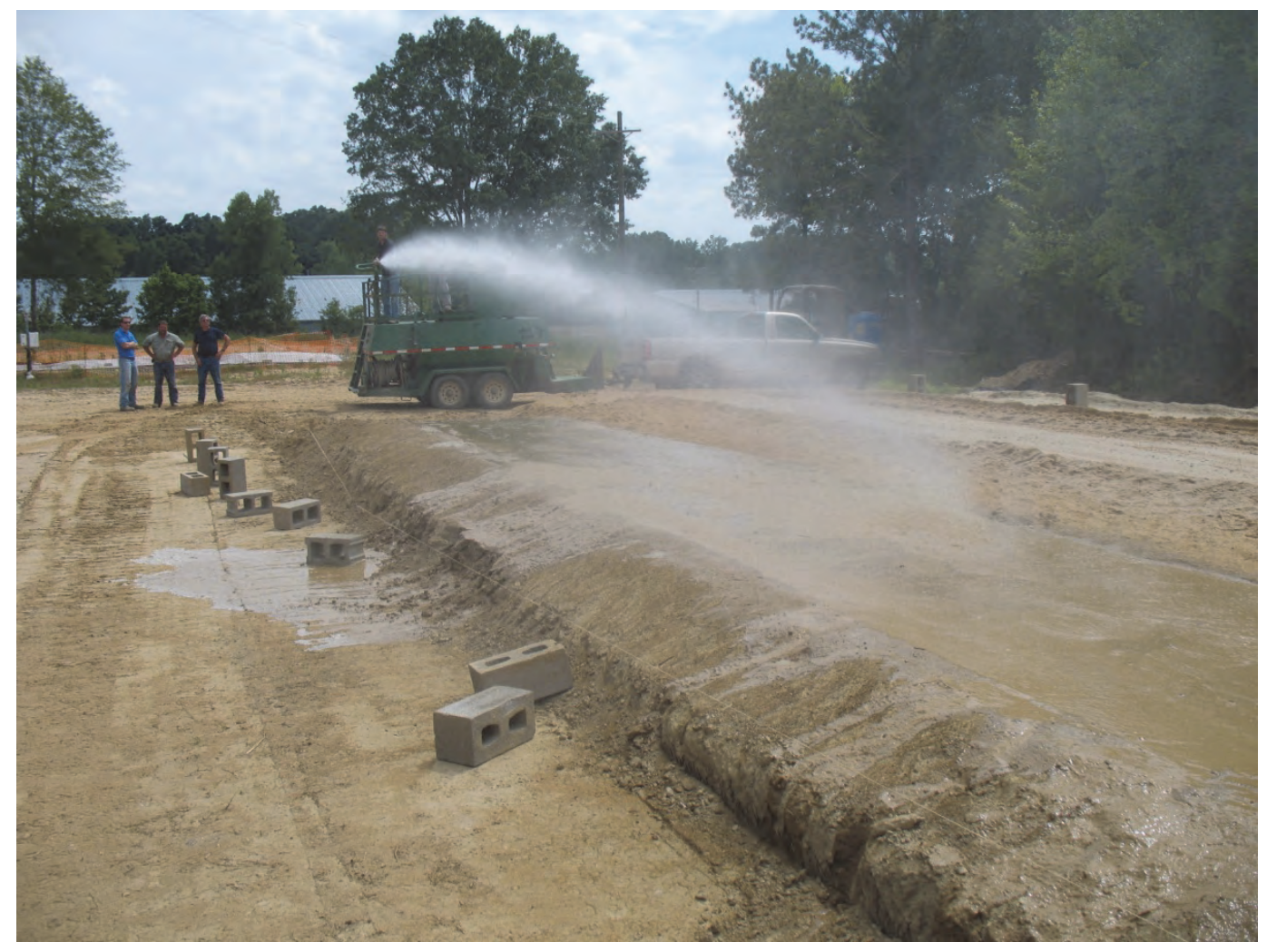

Figure 21. Wetting surface of lift 3 of test item 3 (ML-3) using hydroseeder. 
After all instrument testing was completed on the top lift (lift 3) for each soil test item, a hydroseeder was used to add additional moisture to the surface. An amount of water sufficient to raise the moisture content by several percent based on soil type was sprayed onto the surface and allowed to soak in overnight. The following day, testing continued on the wetted soil to evaluate the response of the stiffness/ strength and electronic devices.

\section{Construction timeline}

In general, test section construction followed this pattern:

- Day 1. Construct and perform tests on lifts 1 and 2 in the morning. Place soils required for lift 3, compact and test coverages 1 and 2 in the afternoon. Cover section with plastic tarp overnight.

- Day 2. Compact and test lift 3, coverages 4 and 8, and moisten soil at end of coverage 8 testing. Construct lifts 1 and 2 for the next soil in the afternoon. Cover both sections with plastic overnight.

- Day 3. Test moistened surface on lift 3. Place and compact soils required for lift 3, compact and test coverages 1 and 2 .

Construction and testing of the seven test items was intended to take approximately six weeks, allowing the three days' testing for each soil and delays for weather. An exceptionally dry and hot May and J une 2010 occurred, allowing construction and testing to occur rapidly. Table 3 provides a general overview of the daily soil and testing operations that occurred.

Of the three rain events during the construction effort, two occurred in consecutive days during the testing of test item 4 . This section was covered in plastic sheeting to protect against vertical infiltration of the moisture, water pooled on either side of the test section. This pooling caused lateral infiltration of moisture into the soil section and resulted in significant strength loss between testing days; eventually requiring removal of a portion of the test section, as shown in Figure 22.

\section{Instrument calibrations}

Each of the electrical devices tested, required some form of device calibration in order to properly correlate the soil's dielectric properties with moisture content and density. Readings obtained from each device are soil specific, and some knowledge of the soil's engineering properties must be 
Table 3. Construction timeline for 7 soil test items

\begin{tabular}{|c|c|}
\hline Date & (TI = test item ) \\
\hline \multirow[t]{3}{*}{$5 / 4 / 2010$} & Collected NDG and DCP data on TI-1 subgrade \\
\hline & Compacted lifts 1 and 2 of TI-1 and tested with SDG and NDG \\
\hline & Calibrated the EDG device on TI-1 soil \\
\hline $5 / 5 / 2010$ & Compacted lift 3 pass 1,2 and 4 on TI-1 and perfomed test series \\
\hline \multirow[t]{5}{*}{$5 / 6 / 2010$} & Compacted lift 3 pass 8 on TI-1 and performed test series \\
\hline & Collected NDG and DCP data on TI-3 subgrade \\
\hline & Compacted lifts 1 and 2 of TI-3 and tested with SDG and NDG \\
\hline & Prepared loose lift 3 of TI-3 and covered with plastic sheet overnight \\
\hline & Sprayed TI-1 with 250 gal of water to soak overnight \\
\hline $5 / 7 / 2010$ & Wetted section of $\mathrm{TI}-1$ was tested \\
\hline \multirow[t]{2}{*}{$5 / 10 / 2010$} & Calibrated the EDG device on TI-3 soil \\
\hline & Compacted lift 3 pass 1, 2 and 4 on TI- 3 and perfomed test series \\
\hline \multirow[t]{4}{*}{$5 / 11 / 2010$} & Compacted lift 3 pass 8 on TI-3 and performed test series \\
\hline & CollectedNDG and DCP data on TI-2 subgrade \\
\hline & Compacted lifts 1 and 2 of TI- 2 and tested with SDG and NDG \\
\hline & Calibrated the EDG device onTI-2 soil \\
\hline \multirow[t]{3}{*}{$5 / 12 / 2010$} & Compacted lift 3 pass 1, 2, 4 and 8 on TI-2 and perfomed test series \\
\hline & Sprayed TI-3 with 250 gal of water to soak overnight \\
\hline & Sprayed TI-2 with 275 gal of water to soak overnight \\
\hline \multirow[t]{2}{*}{$5 / 13 / 2010$} & Wetted section of $\mathrm{TI}-3$ was tested \\
\hline & Wetted section of TI-2 was tested \\
\hline \multirow[t]{4}{*}{$5 / 19 / 2010$} & Collected NDG and DCP data on TI-5 subgrade \\
\hline & Compacted lifts 1 and 2 of TI-5 and tested with SDG and NDG \\
\hline & Brought in additional TI-5 material from supplier for lift 3 \\
\hline & Calibrated the EDG device on TI-5 soil \\
\hline \multirow[t]{2}{*}{$5 / 20 / 2010$} & Compacted lift 3 pass 1,2 and 4 on TI-5 and perfomed test series \\
\hline & TI-5 covered with plastic sheet overnight due to rain \\
\hline \multirow[t]{2}{*}{$5 / 21 / 2010$} & Compacted lift 3 pass 8 on TI-5 and performed test series \\
\hline & Sprayed TI-5 with 250 gal of water to soak over the weekend \\
\hline \multirow[t]{5}{*}{$5 / 24 / 2010$} & Collected NDg and DCP data on TI-4 subgrade \\
\hline & Compacted lifts 1 and 2 of TI-4 and tested ONLY lift 2 with SDG and NDG \\
\hline & Calibrated the EDG device on TI-4 soil \\
\hline & Wetted section of TI-5 was tested \\
\hline & Prepared loose lift 3 of $\mathrm{TI}-4$ and covered with plastic sheet overnight \\
\hline \multirow[t]{2}{*}{$5 / 25 / 2010$} & Compacted lift 3 pass 1, 2, 4 and 8 on TI-4 and perfomed test series \\
\hline & Overnight rain caused damage to TI-4 lots 3 and 4 (high moisture) \\
\hline \multirow[t]{4}{*}{$5 / 26 / 2020$} & Wetted section of TI-4 was tested ONLY on lots 1 and 2 \\
\hline & Collected NDG and DCP data on TI-7 subgrade \\
\hline & Compacted lifts 1 and 2 of TI-7 and tested with SDG and NDG \\
\hline & Calibrated the EDG device on TI-7 soil \\
\hline $5 / 27 / 2010$ & Compacted lift 3 pass 1, 2, 4 and 8 on TI-7 and perfomed test series \\
\hline $5 / 28 / 2010$ & Conducted Water Balloon on Lift 3 pass 8 TI-7 \\
\hline \multirow[t]{3}{*}{$6 / 2 / 2010$} & Conducted MDI on Lift 3 pass 8 of TI-7 \\
\hline & Sprayed TI-7 with 250 gal of water allowed to soak for 4 hours \\
\hline & Wetted section of TI-7 was tested \\
\hline \multirow[t]{3}{*}{$6 / 7 / 2010$} & Collected NDG and DCP data on TI-6 subgrade \\
\hline & Compacted lifts 1 and 2 of TI-6 and tested with SDG and NDG \\
\hline & Calibrated the EDG device on TI-6 soil \\
\hline \multirow[t]{2}{*}{$6 / 8 / 2010$} & Compacted lift 3 pass 1 and 2 on TI- 6 and perfomed test series \\
\hline & Wetted the surface and covered with Visqueen overnight \\
\hline $6 / 9 / 2010$ & Compacted lift 3 pass 4 and 8 on Tl-6 and performed test series \\
\hline
\end{tabular}




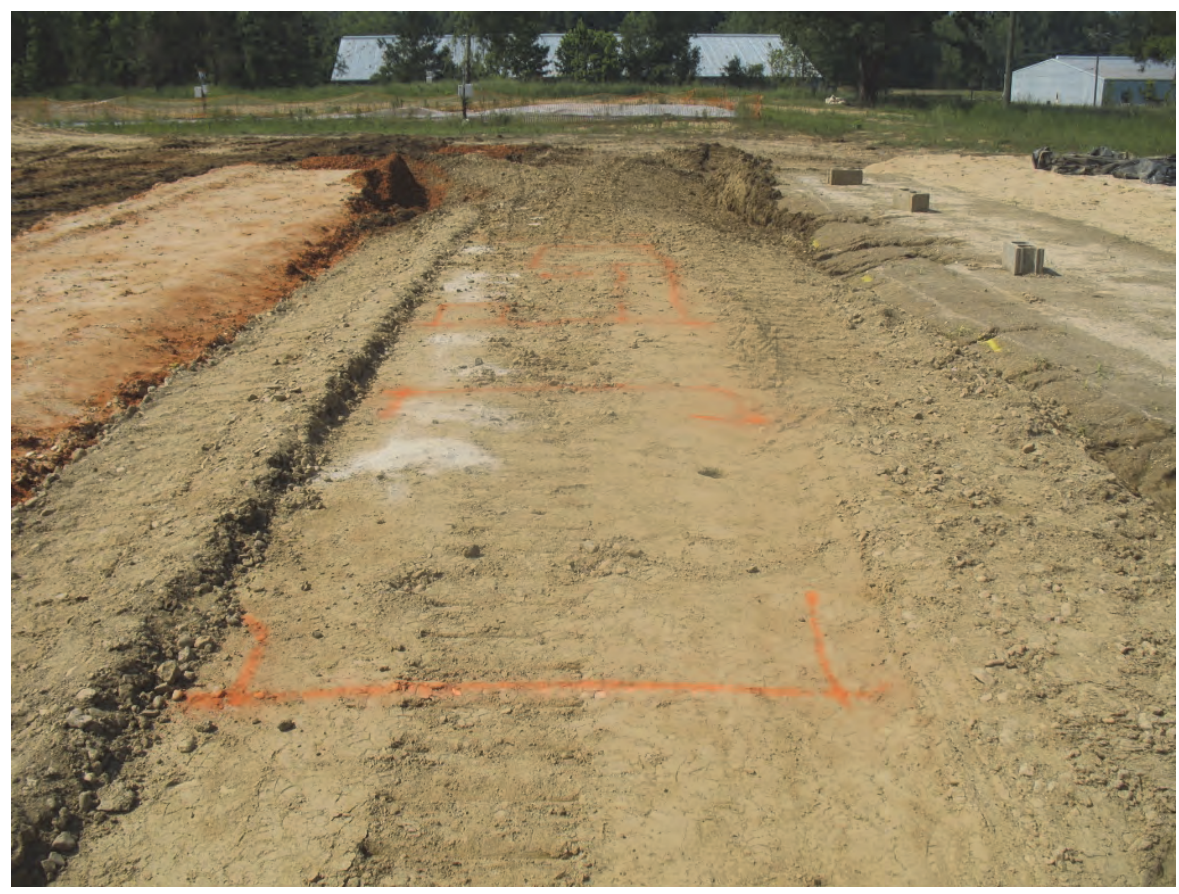

Figure 22. Damage on test item 4, lots 3 and 4.

known prior to interpreting the device output. Determining a suitable replacement to the NDG requires consideration of the time and effort involved in device calibration. Since the NDG requires no soil-specific calibration, any time spent on this effort reflects negatively on the overall device performance. Calibration on any of these devices can be done pretest or posttest, as they all provide a means to correct the raw field data readings.

\section{Moisture Density Indicator (M+DI)}

The manufacturer of the M+DI provided a built-in set of dielectric constants for a variety of soil gradations. As a first run calibration of the device, this was the chosen method. For each soil tested, a moisture-density curve of similar USCS soil classification was selected as representative dielectric data. The ML silt was pre-calibrated by the M+DI manufacturer prior to its delivery to ERDC, and no estimation was required. Figure 23 shows the fit of the best available curves to the gradations obtained from the laboratory. A planned posttest laboratory calibration was to be performed to correct the field measurements. The posttest calibration for the M+DI involved performing the standard ASTM D698 Proctor test with ASTM's proprietary proctor density molds (10-cm-diameter stainless steel casing with a plastic base). Ideally, five data points of varying moisture and density would be tested in the 10-cm-diameter molds to obtain the necessary model 

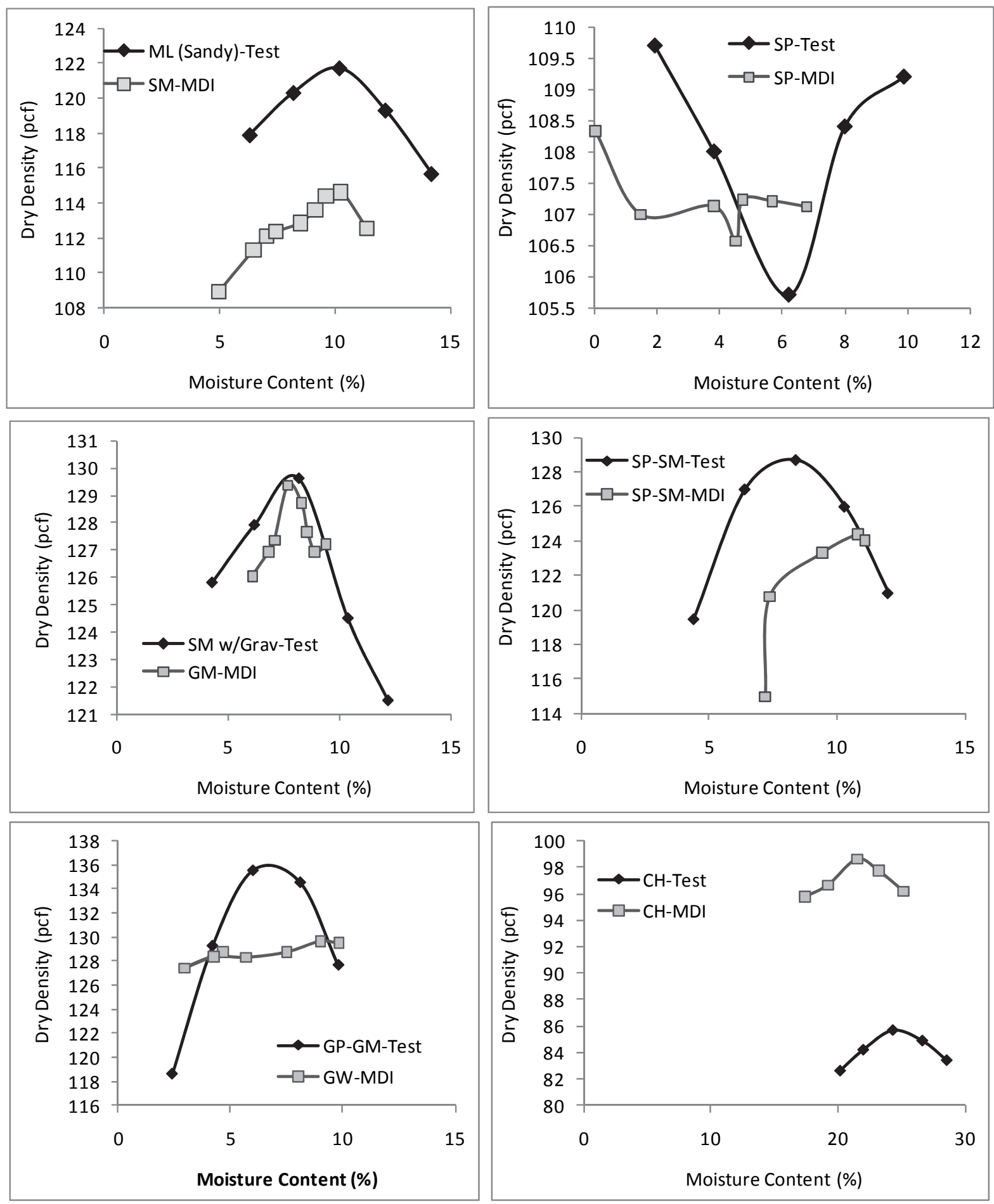

Figure 23. Moisture-Density approximations for calibrating the M+DI device.

coefficients. The poor device functionality in the field as detailed in Chapter 4 eliminated the M+DI from consideration as an acceptable replacement to the NDG; therefore, no posttest calibration was performed. As well, the manufacturer explains: 
"The M+DI has been used successfully for testing base and sub-base materials. However, the M+DI may not be appropriate for aggregates or earth-rock mixtures that either interfere with penetration of the probes or have numerous and large void spaces."

This meant that three of the seven soils would not have been able to be properly tested or calibrated using the M+DI, an unacceptable restriction to the device's operation.

\section{Electrical Density Gauge (EDG)}

According to the manufacturer, the ideal calibration scenario for the EDG is to obtain data in the laboratory at nine distinct points bounding a moisture-density Proctor curve. A 3x3 matrix of points consisting of each combination of three moisture contents (optimum moisture content, dry of optimum, and wet of optimum) and three densities (low, medium, and maximum), as shown on the right side of Figure 24, would be taken. A reduced set of calibration data with a $2 \times 2$ matrix of points was a secondary option. However, for deployment of this device in a military scenario, a field-capable calibration scheme was desired. A compromise provided a three-point calibration scheme making use of the various pass levels of the compactors and the stockpiled material for each soil type shown on the left side of Figure 24. Microwave drying was employed to expedite obtaining the moisture content, thereby simulating a more realistic field scenario for calibration. Calibration occurred as follows:

1. During the first pass of the second lift of each soil, a data point representing a low density-optimum moisture content was obtained and correlated to an NDG wet density and a microwave moisture content.

2. A second data point representing maximum density-optimum moisture content, correlated to an NDG wet density and a microwave moisture content was obtained during the last pass of the second lift of each soil.

3. A small pad of soil 6 to 8 in. deep was placed to the side of the soil stockpile, left to dry during the day with frequent remixing to allow moisture removal, and compacted with one pass of the roller, providing low density-low moisture content correlated to an NDG wet density and microwave moisture content (Figure 25).

Table 4 presents a summary of the field data collected for each soil type for calibration of the EDG. Only one calibration was performed for the sand $\mathrm{w} /$ clay and gravel (SP-SC) material even though there were some minor 
differences in classification between lifts 1 and 2 versus lift 3. The CH, SPSC, and SM soils deviated from the above procedure by using portions of data from lifts 1 and 3 instead of only lift 2.

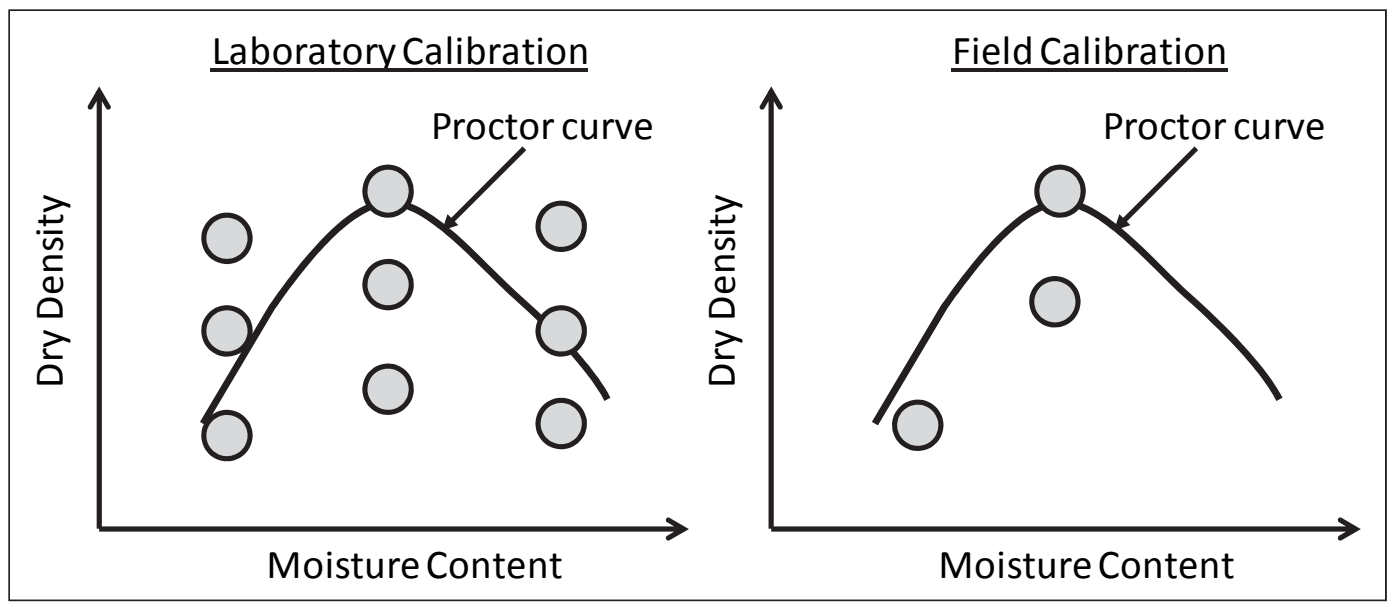

Figure 24. Illustration of laboratory versus ERDC field calibration for EDG.
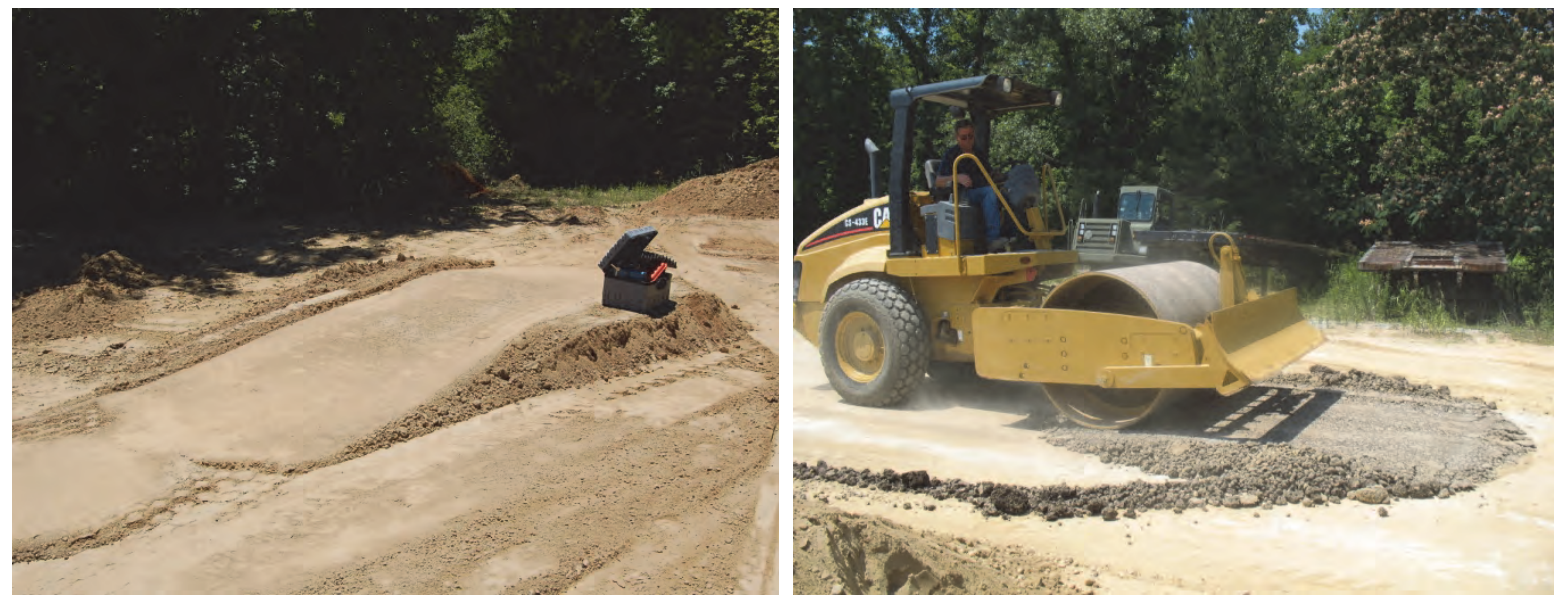

Figure 25. Low moisture-low density calibration pad for EDG on ML-1 (left) and $\mathrm{CH}$ (right)

\section{Soil Density Gauge (SDG)}

The SDG requires two forms of calibration to operate properly. The impedance spectra obtained from the device is correlated to the grain size distribution and Atterberg limits (the soil classification) to obtain a moisture content and dry density value for the reading based on an internal database of studied soils. The following soil classification properties are required:

- Percent larger than 3-in.-(76.2 mm) diameter,

- Percent larger than $3 / 4$-in.-(19 mm) diameter, 
Table 4. Electrical density gauge calibration points.

\begin{tabular}{|c|c|c|c|c|}
\hline & & Microwave & NDG & Calculated \\
\hline Test Item/ & Lift & Water Content & Wet Density & Dry Density \\
\hline Soil Class. & Location & (\%) & (pcf) & (pcf) \\
\hline \multirow[t]{3}{*}{1 - ML-1 } & Stockpile & 15.6 & 113.4 & 98.1 \\
\hline & Lift 2-Pass 1 & 20.0 & 122.4 & 102.0 \\
\hline & Lift 2-Pass 8 & 20.1 & 123.7 & 103.0 \\
\hline \multirow[t]{3}{*}{$2-M L-3$} & Stockpile & 11.94 & 118.2 & 105.5 \\
\hline & Lift 3-Pass 1 & 12.29 & 120.8 & 107.6 \\
\hline & Lift 2-Pass 8 & 13.05 & 131.6 & 116.4 \\
\hline \multirow[t]{3}{*}{3 - SP } & Stockpile & 0.93 & 102.7 & 101.8 \\
\hline & Lift 2-Pass 1 & 5.45 & 109.3 & 103.7 \\
\hline & Lift 2-Pass 8 & 5.06 & 109.9 & 104.6 \\
\hline \multirow[t]{3}{*}{4 - SM } & Stockpile & 6.34 & 130.1 & 122.3 \\
\hline & Lift 2-Pass 1 & 9.03 & 134.4 & 123.3 \\
\hline & Lift 2-Pass 8 & 8.24 & 136.9 & 126.5 \\
\hline \multirow[t]{3}{*}{5 - SP-SC } & Stockpile & 9.80 & 125.6 & 114.4 \\
\hline & Lift 2-Pass 1 & 7.17 & 130.9 & 122.1 \\
\hline & Lift 1-Pass 8 & 5.99 & 139.1 & 131.2 \\
\hline \multirow[t]{3}{*}{$6-\mathrm{CH}$} & Stockpile & 21.77 & 106.7 & 87.6 \\
\hline & Lift 2-Pass 1 & 27.41 & 110.8 & 87.0 \\
\hline & Lift 1-Pass 8 & 27.43 & 117.5 & 92.2 \\
\hline \multirow[t]{3}{*}{ 7-GP-GM } & Stockpile & 2.00 & 123.5 & 121.1 \\
\hline & Lift 2-Pass 1 & 3.30 & 136.3 & 131.9 \\
\hline & Lift 2-Pass 8 & 3.21 & 142.1 & 137.7 \\
\hline
\end{tabular}

- Percent gravel larger than $4.75 \mathrm{~mm}$,

- Percent sand $(4.75 \mathrm{~mm}>$ sand $>0.075 \mathrm{~mm})$,

- Plastic Limit (PL),

- Liquid Limit (LL),

- Uniformity Coefficient $(\mathrm{Cu})$, and

- Coefficient of Gradation (CC).

These input data determine the appropriate calibration curve to be selected for the soil of interest. Appendix B shows the grain size and Atterberg values from which the input properties were obtained.

The second calibration required is a comparison of the device output for dry density to that of a field measured dry density by a secondary 
technique (NDG, SC, etc.). The manufacturer recommends at least three independent data points be taken in the field and averaged to provide the required dry density offset value. For this experiment, an average of the four dry density NDG readings taken on the final lift (lift 3) from the first roller pass was compared to the average dry density SDG readings for the same pass level. The average difference in measured dry density was entered as offsets in the SDG device, as shown in Table 5. This provided an internal linear offset to the density values produced by the SDG and was applied to all subsequent data readings. As can be seen from the table, the SDG offset can be quite variable depending on whether the data taken at the beginning (1 $1^{\text {st }}$ pass) or the end ( $8^{\text {th }}$ pass) of compaction are based on the final compacted conditions of the underlying soil lifts (1 or 2 ).

Table 5. Dry density offsets for SDG calibration.

\begin{tabular}{|c|c|c|c|c|c|c|c|c|c|c|c|c|c|}
\hline Test & Soil & 1st pass & Average & & & 8th pass & Averag & & & 2nd lift & ata pol & & \\
\hline Item & Type & NDG & SDG & Offset & $\mathrm{MC}$ & NDG & SDG & Offset & $\mathrm{MC}$ & NDG & SDG & Offset & $\mathrm{MC}$ \\
\hline 1 & ML- 1 & 91.1 & 102.5 & -11.4 & 17.4 & 99.7 & 93.2 & 6.5 & 15.5 & 98.7 & 107.7 & -9.0 & 19.3 \\
\hline 2 & SP & 104.2 & 98.5 & 5.7 & 4.8 & 102.6 & 95.5 & 7.1 & 6.5 & 105.5 & 104.2 & 1.3 & 4.9 \\
\hline 3 & $M L-3$ & 106.7 & 99.3 & 7.4 & 12.7 & 115.7 & 86.8 & 29.0 & 10.2 & 116.5 & 111.6 & 4.9 & 12.1 \\
\hline 4 & SM & 124.0 & 114.7 & 9.3 & 7.9 & 124.7 & 109.0 & 15.7 & 7.9 & & & & \\
\hline 5 & SP-SM & 117.3 & 101.9 & 15.4 & 6.8 & 117.7 & 98.5 & 19.2 & 6.1 & 126.1 & 100.2 & 25.9 & 7.3 \\
\hline 6 & $\mathrm{CH}$ & 81.3 & 91.0 & -9.7 & 26.9 & 82.5 & 86.6 & -4.1 & 28.0 & 82.2 & 86.4 & -4.2 & 31.1 \\
\hline 7 & GP-GM & 123.5 & 100.9 & 22.6 & 6.2 & 132.4 & 101.9 & 30.5 & 2.8 & 138.8 & 102.2 & 36.6 & 3.6 \\
\hline
\end{tabular}

Because the SDG uses a stepwise series of algorithms from which it determines the appropriate calibration equation, a small change in grain size typically does not affect the end result; as the magnitudes of the input values are not part of the calculation scheme. Only when grain size and Atterberg limit changes cause a change in USCS soil classification can the returned density and moisture results vary. In the course of this experiment, small changes in grain size occurred between tested lots, but none were sufficient to require recalibration of the SDG for a given soil type. 


\section{Field Data Collection}

\section{Sampling protocol}

Each of the 12 devices was tested on each soil test section, as prescribed in Table 6. For the first two lifts, only the SDG, NDG, and DCP were conducted. Tests were run on all 12 devices on coverages $1,2,4$, and 8 of the $3^{\text {rd }}$ lift. After wetting of the final lift, only those devices whose values change with respect to moisture (electrical and stiffness/ strength) were tested.

Table 6. Density and modulus device test matrix.

\begin{tabular}{|l|l|l|l|l|l|l|l|}
\hline Device & $\begin{array}{l}\text { Lift 1 } \\
\text { Final } \\
\text { Cov. }\end{array}$ & $\begin{array}{l}\text { Lift 2 } \\
\text { Final } \\
\text { Cov. }\end{array}$ & $\begin{array}{l}\text { Lift 3 } \\
\text { Cov. 1 }\end{array}$ & $\begin{array}{l}\text { Lift 3 } \\
\text { Cov. 2 }\end{array}$ & $\begin{array}{l}\text { Lift 3 } \\
\text { Cov. 4 }\end{array}$ & $\begin{array}{l}\text { Lift 3 } \\
\text { Cov. 8 }\end{array}$ & $\begin{array}{l}\text { Lift 3 } \\
\text { Cov. 8 } \\
\text { Wetted }\end{array}$ \\
\hline EDG & & & $X$ & $X$ & $X$ & $X$ & $X$ \\
\hline SDG & $X$ & $X$ & $X$ & $X$ & $X$ & $X$ & $X$ \\
\hline M+DI & & & $X$ & $X$ & $X$ & $X$ & $X$ \\
\hline Z-LWD & & & $X$ & $X$ & $X$ & $X$ & $X$ \\
\hline D-LWD & & & $X$ & $X$ & $X$ & $X$ & $X$ \\
\hline DCP & $X$ & $X$ & $X$ & $X$ & $X$ & $X$ & $X$ \\
\hline Clegg & & & $X$ & $X$ & $X$ & $X$ & $X$ \\
\hline SDG & & & $X$ & $X$ & $X$ & $X$ & $X$ \\
\hline WB & & & $X$ & $X$ & $X$ & $X$ & \\
\hline SS & & & $X$ & $X$ & $X$ & $X$ & \\
\hline NDG & $X$ & $X$ & $X$ & $X$ & $X$ & $X$ & $X$ \\
\hline SC & & & $X$ & $X$ & $X$ & $X$ & \\
\hline
\end{tabular}

To provide replicates of device response for each soil under each compacttion/moisture level, each test item was broken down into four test regions, as shown in Figure 26. These regions were contained within the central $40 \mathrm{ft}$ of the test item. This was to ensure that no end effects due to an accelerating or braking compactor adversely affected the density. Each test region was 10-ft-long and 4-ft-wide. The narrower width ensured that edge effects due to low compaction on the sides of the embankment did not influence device response. Each device and its respective data type, as outlined in Table 1, were performed in each of the four test regions. Each device was randomly placed in each test region with care being taken not to overlap any area 
where a volumetric (i.e., destructive) test had been run. Following the testing of each device, a soil sample of approximately 200-300 grams was taken at the center of each test location from the top 5-10 cm of the ground surface to be tested for oven-dried moisture content.

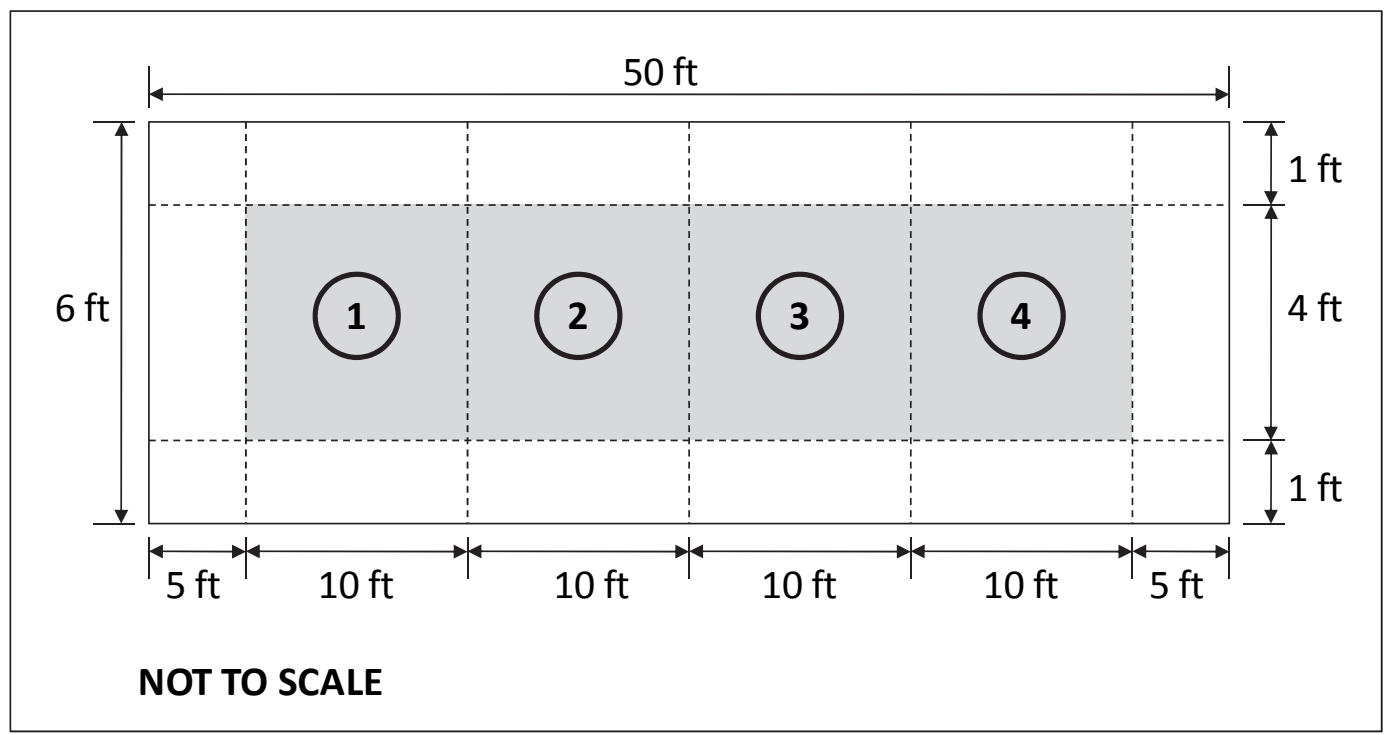

Figure 26. Layout of sampling locations for each soil test item.

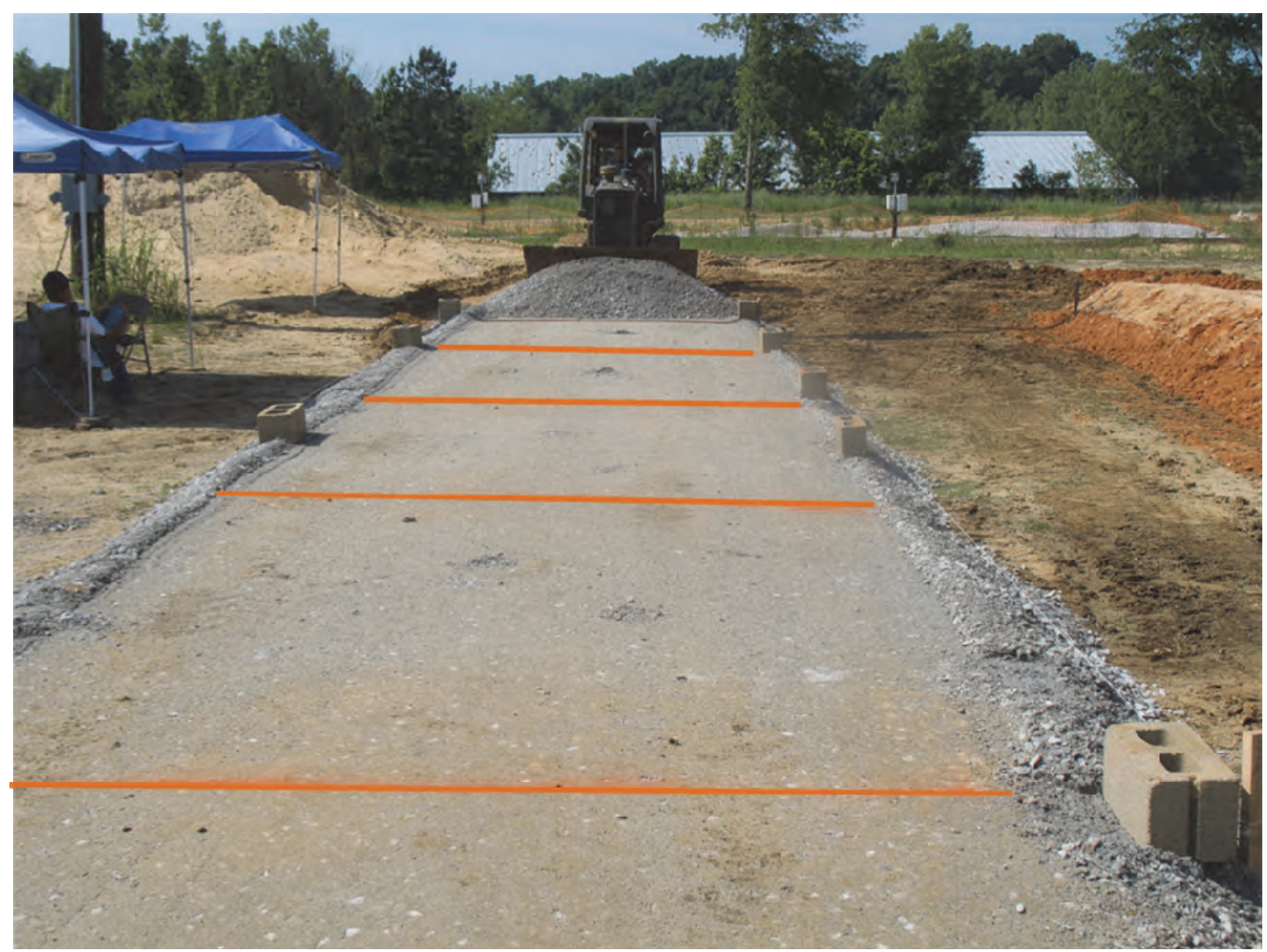

Figure 27. Locations of sampling areas on GP-GM test section. 


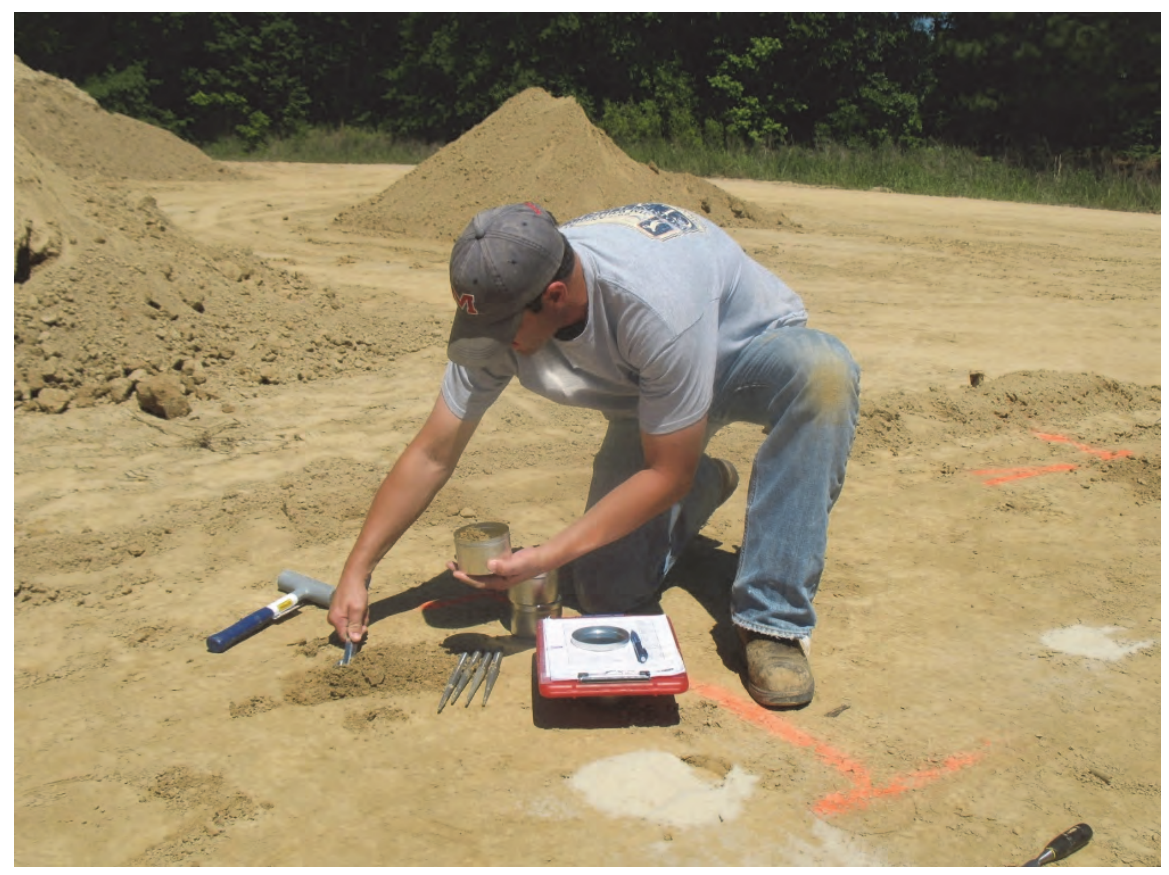

Figure 28. Collecting soil sample for moisture content determination.

Multiple personnel were used in the data collection effort, although effort was taken to ensure that each device primarily had only a single or at most two operators throughout the entire experiment. Table 7 shows an approximate breakdown of the time required to conduct each of the 12 tests and the number of technicians in operation at any one time for a given test item and coverage level. Devices were tested concurrently by multiple personnel, as shown in Figure 29. A second set of personnel was present to collect and label moisture content samples for all devices tested.

Table 7. Approximate time and personnel breakdown for each tested device.

\begin{tabular}{|c|c|c|c|c|c|c|c|c|c|c|c|c|c|c|c|c|c|c|c|c|c|c|}
\hline \multirow{2}{*}{$\begin{array}{l}\text { Tech } \\
\text { No. }\end{array}$} & \multirow[b]{2}{*}{ Device } & \multicolumn{19}{|c|}{ Approximate time in minutes to perform 4 replicate tests } & \multirow{2}{*}{\multicolumn{2}{|c|}{100105110115}} \\
\hline & & 5 & 10 & 15 & 20 & 25 & 30 & 35 & 40 & 45 & 50 & 55 & 60 & 65 & 70 & 75 & 80 & 85 & 90 & & & \\
\hline 1 & Sand Cone & & & & & & & & & & & & & & & & & & & & & \\
\hline 2 & D-LWD & & & & & & & & & & & & & & & & & & & & & \\
\hline 2 & Z-LWD & & & & & & & & & & & & & & & & & & & & & \\
\hline 2 & EDG & & & & & & & & & & & & & & & & & & & & & \\
\hline 3 & MDI & & & & & & & & & & & & & & & & & & & & & \\
\hline 3 & Steel Shot & & & & & & & & & & & & & & & & & & & & & \\
\hline 4 & SDG & & & & & & & & & & & & & & & & & & & & & \\
\hline 4 & GeoGauge & & & & & & & & & & & & & & & & & & & & & \\
\hline 5 & Water Balloon & & & & & & & & & & & & & & & & & & & & & \\
\hline 5 & Clegg & & & & & & & & & & & & & & & & & & & & & \\
\hline 6 & NDG & & & & & & & & & & & & & & & & & & & & & \\
\hline 6 & DCP & & & & & & & & & & & & & & & & & & & & & \\
\hline
\end{tabular}




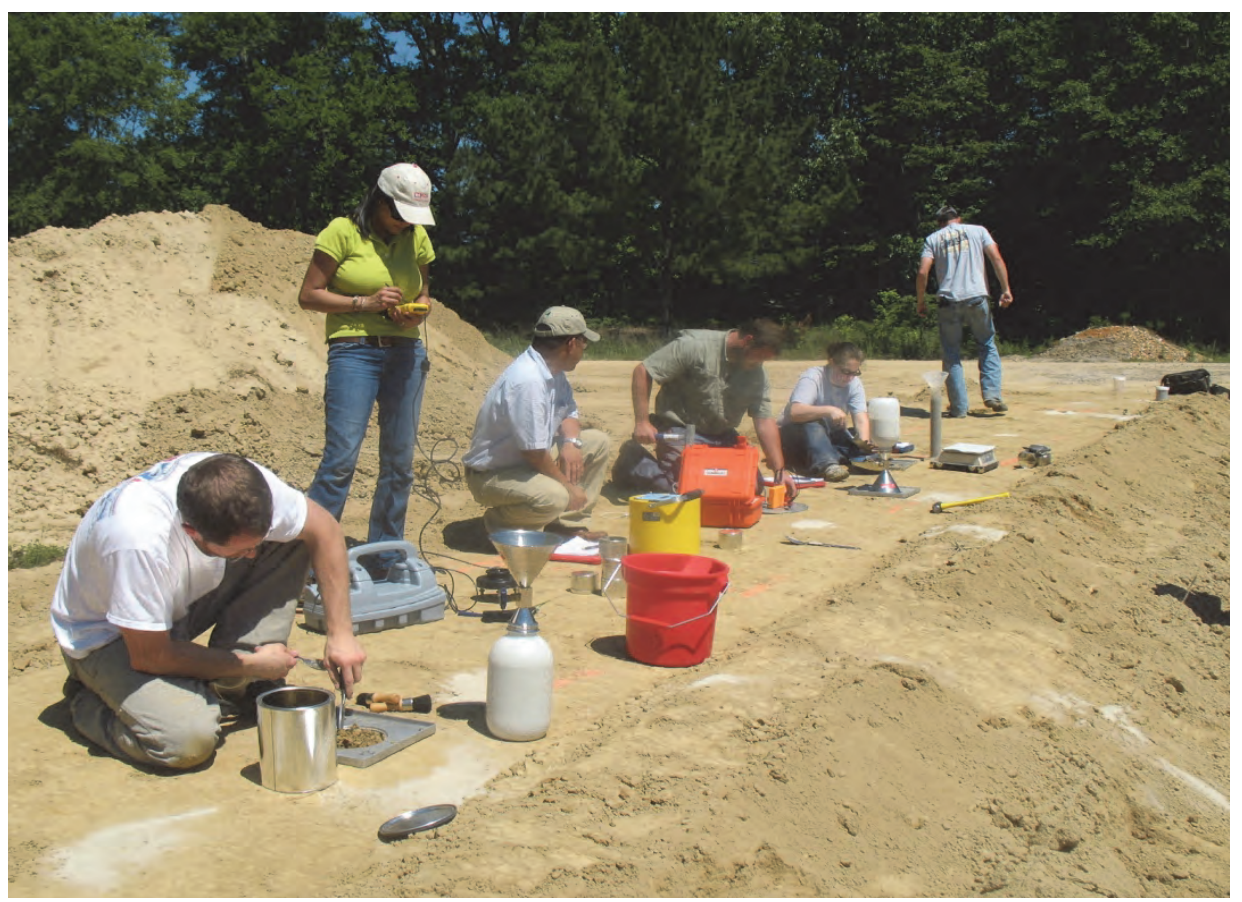

Figure 29. Multiple personnel concurrently testing devices.

\section{Data collected}

Table 8 lists the notations and associated units used during the data collection efforts for each of the 12 devices tested. The reported values for each device are organized by soil type, device, coverage, and section number shown in Table 9. This data served as the basis for the analysis presented in Chapter 5. A complete listing of all collected data is given in Appendix D for each lift (1, 2 and 3), section (1 - 4), coverage/ pass (1, 2, 4 and 8) and at a higher moisture level (8W). Measured moisture contents at each location are shown, along with each data reading.

\section{Device complications}

For military implementation of new technology, it is important that it be easy to use, reliable, and robust to ensure that it will perform in harsh field conditions and by personnel with limited training. The following describes common issues experienced with each density device during testing.

Soil Density Gauge: Knowledge of the soil properties is essential to the effectiveness of this device. Use of the ERDC's Rapid Soils Analysis Kit (RSAK) or similar technique to achieve an estimate of field gradation, Atterberg limits, and classification must be performed on each soil or change in soil during testing. As well, moisture-density data points from the field must be obtained for the device to provide meaningful results. 
Table 8. Notations for field data collection values.

\begin{tabular}{|c|c|c|c|c|}
\hline Device & $\begin{array}{l}\text { Device } \\
\text { Symbol }\end{array}$ & Reported Value & Method & Units \\
\hline Nuclear Density Gauge & NDG & Dry density & $\begin{array}{l}\text { From device wet } \\
\text { density and oven } \\
\text { moisture }\end{array}$ & pcf \\
\hline Sand Cone & SC & Dry density & $\begin{array}{l}\text { From device wet } \\
\text { density and oven } \\
\text { moisture }\end{array}$ & pcf \\
\hline Water Balloon & WB & Dry density & $\begin{array}{l}\text { From device wet } \\
\text { density and oven } \\
\text { moisture }\end{array}$ & pcf \\
\hline Steel Shot & SS & Dry density & $\begin{array}{l}\text { From device wet } \\
\text { density and oven } \\
\text { moisture }\end{array}$ & pcf \\
\hline $\begin{array}{l}\text { Electrical Density } \\
\text { Gauge }\end{array}$ & EDG & Dry density & $\begin{array}{l}\text { From device wet } \\
\text { density and oven } \\
\text { moisture }\end{array}$ & pcf \\
\hline Soil Density Gauge & SDG & Dry density & $\begin{array}{l}\text { From device wet } \\
\text { density and oven } \\
\text { moisture }\end{array}$ & pcf \\
\hline $\begin{array}{l}\text { Moisture Density } \\
\text { Indicator }\end{array}$ & MDI & Dry density & $\begin{array}{l}\text { From device wet } \\
\text { density and oven } \\
\text { moisture }\end{array}$ & pcf \\
\hline Dynatest Falling Weight & DFW & Deflection & Device reading & $\mu \mathrm{m}$ \\
\hline Zorn Falling Weight & ZFW & Deflection & Device reading & $\mathrm{mm}$ \\
\hline GeoGauge & GG & Modulus & Device reading & $\begin{array}{l}\text { kip/in. (3 reading } \\
\text { average) }\end{array}$ \\
\hline $\begin{array}{l}\text { Dynamic Cone } \\
\text { Penetrometer }\end{array}$ & DCP & Blows/150 mm & Device reading & total blow count \\
\hline Clegg Hammer & Clegg & $\begin{array}{l}\text { Clegg Impact } \\
\text { Value }\end{array}$ & Device reading & CIV \\
\hline
\end{tabular}

Dynatest Lightweight Deflectometer: The DFW measures the strains of the soil at the point of contact with the ground surface. Large strains in the soil surface can occur when the soil is very wet or poorly compacted, overranging the strain gauge and resulting in no reading. This occurred in the silt material. This device also requires a third party Bluetooth data acquisition unit. Dependence on this mode of communication can lead to hardware and operating system compatibility issues as well as ineffectiveness in areas where Bluetooth jamming is ongoing. 
Table 9. Summary of field data by soil, device, coverage level, and section.

\begin{tabular}{|c|c|c|c|c|c|c|c|c|c|c|c|c|c|c|c|c|c|}
\hline & \multirow{2}{*}{\begin{tabular}{|c|} 
Section \\
Pass \\
\end{tabular}} & \multicolumn{4}{|c|}{1} & \multicolumn{4}{|c|}{2} & & \\
\hline & & 1 & 2 & 4 & 8 & 1 & 2 & 4 & 8 & $\overline{1}$ & 2 & 4 & 8 & 1 & 2 & 4 & 8 \\
\hline Soil & Device & & & & & & & & & & & & & & & & \\
\hline $\mathrm{CH}$ & Clegg & & \begin{tabular}{|l|}
13.3 \\
\end{tabular} & \begin{tabular}{|l|}
13.3 \\
\end{tabular} & 9.9 & & \begin{tabular}{|l|}
13.8 \\
\end{tabular} & 0 & .5 & & 9.9 & 9.3 & 4.9 & & 9.9 & 9.3 & 4.9 \\
\hline SM & & 11.0 & 11.5 & 14.6 & 8.8 & 9.1 & 9.7 & 12.3 & 11.0 & 9.1 & 5.3 & 7.2 & 8.3 & 9.1 & 5.3 & 7.2 & 8.3 \\
\hline GP-GM & & \begin{tabular}{|l|}
12.9 \\
\end{tabular} & \begin{tabular}{|l|}
17.2 \\
\end{tabular} & \begin{tabular}{|l|}
20.8 \\
\end{tabular} & 26.2 & 14.6 & 26.0 & \begin{tabular}{|l|}
19.0 \\
\end{tabular} & \begin{tabular}{|l|}
29.7 \\
\end{tabular} & \begin{tabular}{|l|}
17.0 \\
\end{tabular} & 16.0 & 18.7 & 23.8 & \begin{tabular}{|l|}
17.0 \\
\end{tabular} & 16.0 & 18.7 & 23.8 \\
\hline \begin{tabular}{ll|}
$M L-1$ \\
\end{tabular} & & 4.0 & 3.9 & 5.1 & & 3.7 & 5.3 & 4.2 & & 3.2 & 3.9 & 4.2 & & 3.2 & 3.9 & 4.2 & \\
\hline SP-SM & & 6.0 & 1.2 & 7.9 & 12.0 & 0.0 & 7.7 & 6. & 10.9 & 7.6 & 8.8 & 6.2 & 0.5 & 7.6 & 8.8 & 6.2 & 10.5 \\
\hline ML-3 & & 5.7 & 7.3 & 6.2 & 10.1 & 5.8 & 8.9 & 8.5 & 8.4 & 9.8 & \begin{tabular}{l|l|}
10.8 \\
\end{tabular} & 8.5 & 9.3 & 9.8 & 10.8 & 8.5 & 9.3 \\
\hline SP & & 2.8 & 2.0 & 2.4 & 2. & 2.6 & 2.0 & 1.7 & 2.8 & 3.1 & 1.8 & 1.7 & 2.6 & 3.1 & 1.8 & 1.7 & 2.6 \\
\hline $\mathrm{CH}$ & CP & 8 & 10 & 12 & 10 & 10 & 8 & 10 & 6 & 8 & 8 & 8 & 9 & 9 & 10 & 12 & 12 \\
\hline SM & & 9 & 8 & 9 & 11 & 12 & 9 & & 11 & 15 & & & & & & & 7 \\
\hline GP-GM & & 7 & 7 & 9 & & $\sigma_{0}$ & 10 & 11 & & 2 & & & & & & 12 & \\
\hline ML-1 & & 4 & 5 & 5 & 7 & 3 & & 5 & & & 4 & 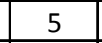 & & & & & 6 \\
\hline SP-SM & & 5 & 5 & 8 & 10 & 4 & 5 & 7 & 8 & 4 & 6 & 6 & & 4 & 6 & 10 & 7 \\
\hline ML-3 & & 8 & 9 & 10 & 1. & 6 & 11 & 8 & & & 6 & & 1 & 5 & & & 12 \\
\hline SP & & 2 & 3 & & 3 & 3 & & 3 & & & & & & & & & 4 \\
\hline $\mathrm{CH}$ & DG & 85.3 & 81.8 & 85.6 & 85.2 & 86.3 & 83.3 & 84.3 & 86.6 & 7.1 & 79.8 & 85.9 & 83.8 & 85.4 & 2.2 & 82.6 & 83.4 \\
\hline SM & & 6 & \begin{tabular}{|l|}
120.9 \\
\end{tabular} & \begin{tabular}{|l|l|}
124.3 \\
\end{tabular} & 17.9 & \begin{tabular}{|l|}
119.3 \\
\end{tabular} & 8 & 121.8 & 12 & 1.7 & \begin{tabular}{|l|l|}
117.5 \\
\end{tabular} & \begin{tabular}{|l|}
121.3 \\
\end{tabular} & 118.6 & 22.0 & 9 & 7 & 119.4 \\
\hline GP-GM & & \begin{tabular}{|l|}
127.7 \\
\end{tabular} & 133.4 & $\mid 130.7$ & 129.1 & 27.9 & 130.9 & 130.5 & 126.1 & \begin{tabular}{|l|}
126.9 \\
\end{tabular} & \begin{tabular}{|l|}
131.2 \\
\end{tabular} & 127.6 & 132.2 & 24.3 & 3 & 99.3 & 1.4 \\
\hline ML-1 & & 3.7 & \begin{tabular}{|l|}
96.3 \\
\end{tabular} & 92.6 & 19.6 & \begin{tabular}{|l|}
113.7 \\
\end{tabular} & 108.4 & 87.5 & \begin{tabular}{|l|}
109.7 \\
\end{tabular} & 5.1 & 74.0 & 75.9 & 121.7 & 20.3 & 7 & & 13.8 \\
\hline SP-SM & & 115.8 & \begin{tabular}{|l|}
121.1 \\
\end{tabular} & \begin{tabular}{|l|}
113.8 \\
\end{tabular} & 120.5 & 116.2 & 120.2 & 1115.2 & 119.1 & 121.0 & \begin{tabular}{|l|l|}
119.4 \\
\end{tabular} & 119.2 & 118.4 & 122.5 & \begin{tabular}{|l|}
119.5 \\
\end{tabular} & .3 & 1 \\
\hline $\mathrm{ML}-3$ & & 100.5 & \begin{tabular}{|l|}
111.1 \\
\end{tabular} & 109.5 & 113.3 & \begin{tabular}{|l|}
85.2 \\
\end{tabular} & 111.2 & 109.0 & 111.6 & 3.1 & \begin{tabular}{|l|}
111.2 \\
\end{tabular} & 109.5 & 110.7 & 97.9 & 110.3 & .0 & 112.4 \\
\hline SP & & 105.4 & \begin{tabular}{|l|}
104.6 \\
\end{tabular} & \begin{tabular}{|l|}
102.4 \\
\end{tabular} & \begin{tabular}{|l|}
97.6 \\
\end{tabular} & \begin{tabular}{|l|}
106.0 \\
\end{tabular} & 104.3 & 1.3 & & 3.8 & 3.9 & 2.4 & 1.5 & .4 & 3 & -9 & 97.5 \\
\hline $\mathrm{CH}$ & $\mathbf{G}$ & 54.48 & 61.36 & 66.89 & 53.86 & \begin{tabular}{|l|l|}
48.72 \\
\end{tabular} & 55.99 & \begin{tabular}{|l|}
46.69 \\
\end{tabular} & \begin{tabular}{|l|l|}
78.42 \\
\end{tabular} & \begin{tabular}{|l|}
55.47 \\
\end{tabular} & 51.73 & 48.15 & \begin{tabular}{|l|}
49.57 \\
\end{tabular} & 68.72 & \begin{tabular}{|l|l|}
53.33 \\
\end{tabular} & 54 & 59.99 \\
\hline SM & & & \begin{tabular}{|l|}
12.92 \\
\end{tabular} & 86 & .58 & & 34 & 10.13 & 10 & 44 & 2.93 & 2.42 & 2. & 11 & & & \\
\hline GP-GM & & .19 & \begin{tabular}{|l|}
14.96 \\
\end{tabular} & \begin{tabular}{|l|l|}
13.30 \\
\end{tabular} & 14.29 & \begin{tabular}{|l|}
12.93 \\
\end{tabular} & 16.45 & 15.21 & 15.71 & \begin{tabular}{|l|}
14.01 \\
\end{tabular} & 15.05 & \begin{tabular}{|l|}
13.87 \\
\end{tabular} & 12.75 & \begin{tabular}{|l|}
13.44 \\
\end{tabular} & \begin{tabular}{|l|}
14.61 \\
\end{tabular} & \begin{tabular}{|l|}
13.07 \\
\end{tabular} & 14.42 \\
\hline ML-1 & & 57 & 9.53 & 8.82 & 9.23 & 7.96 & 9.32 & 7.43 & 8 & 7.95 & 8.59 & 8.64 & \begin{tabular}{|l|}
8.21 \\
\end{tabular} & 7.91 & 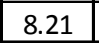 & 10 & 7.31 \\
\hline SP-SM & & .00 & 14.38 & & 12.53 & 15.75 & 13.94 & & 13.29 & 12.50 & 13.26 & & 12.98 & 2.90 & & & 12.16 \\
\hline ML-3 & & 12.27 & 10.55 & \begin{tabular}{|l|l}
5.89 \\
\end{tabular} & 7.81 & \begin{tabular}{|l|}
12.65 \\
\end{tabular} & 9.81 & 6.58 & 9.51 & 13.12 & 9.56 & 8.44 & 11.17 & \begin{tabular}{|l|}
12.49 \\
\end{tabular} & 21 & 3.15 & 10.64 \\
\hline SP & & 26 & 4.30 & 4.46 & 4.16 & 4.17 & 4.15 & 3.80 & 4. & 3.95 & 3.97 & 4.71 & 4.08 & 4.18 & 04 & & 4.31 \\
\hline $\mathrm{CH}$ & NDG & \begin{tabular}{|l|}
81.9 \\
\end{tabular} & 78.1 & 85.1 & \begin{tabular}{|l|}
80.7 \\
\end{tabular} & 81.3 & 78.8 & 85.9 & \begin{tabular}{|l|}
82.9 \\
\end{tabular} & 80.0 & 74.5 & 85.6 & 78.2 & 1.9 & 3.5 & 6.0 & 38.1 \\
\hline SM & & \begin{tabular}{|l|}
122.8 \\
\end{tabular} & \begin{tabular}{|l|}
122.7 \\
\end{tabular} & \begin{tabular}{|l|l|}
127.0 \\
\end{tabular} & 128.1 & 1.0 & 120.1 & \begin{tabular}{|l|}
125.2 \\
\end{tabular} & & \begin{tabular}{|l|}
127.3 \\
\end{tabular} & 3.8 & 6.9 & 5.9 & 5.0 & 7.0 & 3.4 & .5 \\
\hline GP-GM & & 127.0 & \begin{tabular}{|l|}
129.0 \\
\end{tabular} & 132.6 & 136.9 & \begin{tabular}{|l|l|}
111.5 \\
\end{tabular} & 120.1 & \begin{tabular}{|l|}
125.2 \\
\end{tabular} & 123.1 & \begin{tabular}{|l|}
128.8 \\
\end{tabular} & 128.1 & 135.0 & \begin{tabular}{|l|}
135.7 \\
\end{tabular} & \begin{tabular}{|l|}
126.9 \\
\end{tabular} & \begin{tabular}{|l|}
126.9 \\
\end{tabular} & 134.7 & 134 \\
\hline ML-1 & & & & & & & & & & & & & & & & & \\
\hline SP-SM & & 9.4 & 1116.4 & $\mid$\begin{tabular}{|l|}
121.1 \\
\end{tabular} & 120.8 & 116.6 & 116.7 & \begin{tabular}{|l|}
121.5 \\
\end{tabular} & 118 & 116.1 & \begin{tabular}{|l|}
117.1 \\
\end{tabular} & 118.5 & 117 & 2 & & 4 & \\
\hline ML-3 & & 113.1 & 116.9 & 1115.9 & 114.3 & \begin{tabular}{|l|}
99.7 \\
\end{tabular} & 112.6 & 112.8 & 115.0 & 108.7 & \begin{tabular}{|l|}
109.9 \\
\end{tabular} & 112.7 & 116.5 & 105.3 & \begin{tabular}{|l|}
112.9 \\
\end{tabular} & 110.3 & 117.0 \\
\hline SP & & \begin{tabular}{|l|}
104.6 \\
\end{tabular} & \begin{tabular}{|l|}
105.8 \\
\end{tabular} & 104.1 & 104.5 & \begin{tabular}{|l|}
103.5 \\
\end{tabular} & \begin{tabular}{|l|}
104.7 \\
\end{tabular} & 103.1 & 103.6 & \begin{tabular}{|l|}
104.6 \\
\end{tabular} & \begin{tabular}{|l|l|}
104.0 \\
\end{tabular} & \begin{tabular}{|l|}
104.0 \\
\end{tabular} & \begin{tabular}{|l|}
104.2 \\
\end{tabular} & 03.9 & 4.4 & 109.0 & .0 \\
\hline $\mathrm{CH}$ & SC & 88.1 & \begin{tabular}{|l|}
78.4 \\
\end{tabular} & \begin{tabular}{|l|}
89.3 \\
\end{tabular} & 86.0 & \begin{tabular}{|l|}
87.6 \\
\end{tabular} & 87.9 & 79.8 & 91.7 & \begin{tabular}{|l|}
109.4 \\
\end{tabular} & \begin{tabular}{|l|}
91.1 \\
\end{tabular} & \begin{tabular}{|l|}
91.5 \\
\end{tabular} & 89.8 & 82.7 & 3.5 & .6 & 5.3 \\
\hline SM & & 0 & \begin{tabular}{|l|}
127.4 \\
\end{tabular} & 2.7 & \begin{tabular}{|l|}
131.3 \\
\end{tabular} & 3 & 133.0 & 4.5 & \begin{tabular}{|l|l|}
130.4 \\
\end{tabular} & 0.3 & 32.8 & 9.0 & 5.4 & 137.5 & 4.1 & 3.7 & 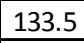 \\
\hline GP-GM & & 134.2 & 132.2 & 135.0 & 140.7 & \begin{tabular}{|l|l|}
125.7 \\
\end{tabular} & 133.8 & 132.5 & 134.8 & 133.0 & \begin{tabular}{|l|}
132.2 \\
\end{tabular} & 139.2 & 138.6 & & 132.5 & \begin{tabular}{|l|}
130.9 \\
\end{tabular} & 138.2 \\
\hline ML-1 & & 92.5 & 99.8 & 92.9 & \begin{tabular}{|l|}
95.8 \\
\end{tabular} & 93.4 & 102.9 & 96.3 & 96.8 & 89.9 & \begin{tabular}{|l|l|}
100.9 \\
\end{tabular} & 98.9 & 95.9 & & 1.6 & 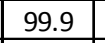 & 97.1 \\
\hline SP-SM & & \begin{tabular}{|l|}
127.9 \\
\end{tabular} & \begin{tabular}{|l|}
127.3 \\
\end{tabular} & 124.5 & 128.4 & 131.5 & 128.0 & 131.6 & 130.0 & 130.2 & 128.5 & 129.2 & 131.0 & 25.7 & 134.2 & 27.2 & 126.3 \\
\hline ML-3 & & 116.8 & \begin{tabular}{|l|}
118.2 \\
\end{tabular} & 122.9 & 118.4 & \begin{tabular}{|l|}
115.9 \\
\end{tabular} & 120.5 & 122.1 & 120.8 & 119.4 & \begin{tabular}{|l|l|}
117.6 \\
\end{tabular} & 113.0 & \begin{tabular}{|l|}
117.9 \\
\end{tabular} & 6.1 & 2.9 & 113.6 & the \\
\hline 4. & & 107.4 & 108.0 & 104.4 & 106.7 & | 106.0 & 107.1 & 103.9 & 108.8 & 105.8 & \begin{tabular}{|l|}
105.2 \\
\end{tabular} & 102.8 & | 110.7 & 106.6 & 109.2 & 105.0 & 10 \\
\hline
\end{tabular}




\begin{tabular}{|c|c|c|c|c|c|c|c|c|c|c|c|c|c|c|c|c|c|}
\hline & \multirow{2}{*}{\begin{tabular}{|c|} 
Section \\
Pass \\
\end{tabular}} & \multicolumn{4}{|c|}{1} & \multicolumn{4}{|c|}{2} & \multicolumn{4}{|c|}{3} & \multicolumn{4}{|c|}{4} \\
\hline & & 1 & 2 & 4 & 8 & 1 & 2 & 4 & 8 & 1 & 2 & 4 & 8 & 1 & 2 & 4 & 8 \\
\hline Soil & \begin{tabular}{|l|} 
Device \\
\end{tabular} & & & & & & & & & & & & & & & & \\
\hline $\mathrm{CH}$ & SS & 109.3 & 98.5 & 81.6 & 97.7 & 97.3 & 97.7 & 103.1 & 99.0 & 96.4 & 109.6 & 100.4 & 103.4 & 103.2 & 96.7 & 103.5 & 90.9 \\
\hline $\mathrm{SM}$ & & 7.3 & \begin{tabular}{|l|}
135.4 \\
\end{tabular} & 131.6 & 129.3 & 132.7 & 133.6 & 134.1 & 125.0 & 129.4 & 135.5 & 127.6 & 132.8 & 37.6 & 126.7 & 141.2 & 123.7 \\
\hline GP-GM & & 118.0 & 141.6 & 136.6 & 129.5 & 139.8 & 143.9 & 125.7 & 147.1 & 133.2 & 144.0 & 134.3 & 114.4 & 134.9 & 144.3 & 124.0 & 139.0 \\
\hline ML-1 & & 88.1 & 94.3 & 97.6 & 97.4 & 88.2 & 98.0 & 93.4 & 94.3 & 83.3 & 96.0 & 95.9 & 96.5 & 85.4 & 94.0 & 96.3 & 99.3 \\
\hline SP-SM & & 33.9 & 133.1 & 99.9 & 127.2 & 132.9 & 129.7 & 128.7 & 123.7 & 127.4 & 133.7 & 126.7 & 124.6 & 120.0 & 152.7 & 126.6 & 133.2 \\
\hline ML-3 & & 4.8 & 113.8 & 111.8 & 118.1 & 101.8 & 101.8 & 112.4 & 111.1 & 100.0 & 107.3 & 118.0 & 125.6 & 115.9 & 121.4 & 126.2 & 125.4 \\
\hline $\mathrm{SP}$ & & 105.5 & 96.4 & 104.3 & 97.0 & 105.0 & 104.3 & 104.7 & 110.5 & \begin{tabular}{|l|}
111.1 \\
\end{tabular} & 100.3 & \begin{tabular}{|l|}
100.2 \\
\end{tabular} & 100.2 & 111.5 & 112.4 & 103.1 & 105.9 \\
\hline$\overline{\mathrm{CH}}$ & $\overline{\mathbf{G G}}$ & 91.2 & 86.6 & 96.2 & 86.7 & 91.4 & 87.3 & 92.2 & 77.3 & 89.6 & 93.1 & 86.0 & \begin{tabular}{|l|}
88.2 \\
\end{tabular} & 91.6 & 92.2 & 9.6 & 94.2 \\
\hline SM & & 116.0 & 109.3 & 108.5 & 108.3 & 113.3 & 111.0 & 109.5 & 108.5 & 115.6 & 109.7 & 110.9 & \begin{tabular}{|l|}
110.0 \\
\end{tabular} & 13.9 & 108.9 & 111.1 & 109.0 \\
\hline GP-GM & & 99.9 & 100.2 & 101.0 & 101.5 & 99.7 & 101.7 & 101.2 & 102.8 & 102.1 & 101.1 & 100.5 & 101.6 & 99.9 & 100.9 & 100.9 & 101.6 \\
\hline ML-1 & & 105.7 & 97.9 & 93.6 & 92.0 & 102.2 & 101.9 & 91.5 & 94.0 & 103.0 & 98.6 & 92.3 & 95.0 & 99.0 & 100.5 & 86.9 & 91.9 \\
\hline SP-SM & & 101.4 & 99.4 & 97.6 & 98.5 & 101.1 & 100.1 & 98.8 & 98.3 & 101.9 & 99.0 & 96.9 & \begin{tabular}{|l|}
98.1 \\
\end{tabular} & 103.3 & 98.8 & 96.8 & 99.3 \\
\hline ML-3 & & 103.0 & 103.7 & 107.4 & 86.8 & 94.1 & 102.7 & 88.9 & 90.0 & 96.5 & 103.0 & 87.7 & \begin{tabular}{|l|}
84.6 \\
\end{tabular} & 103.6 & 92.2 & 86.7 & 85.6 \\
\hline $\mathrm{SP}$ & & 92.4 & 98.4 & 93.5 & 92.9 & \begin{tabular}{|l|}
101.5 \\
\end{tabular} & \begin{tabular}{|l|}
100.3 \\
\end{tabular} & 97.2 & 93.6 & 102.3 & \begin{tabular}{|l|}
105.6 \\
\end{tabular} & 99.5 & 98.7 & 97.8 & 104.5 & 101.2 & 96.8 \\
\hline $\mathrm{CH}$ & $w$ & 1.67 & 1.35 & 0.64 & 1.63 & 0.75 & 1.62 & 0.97 & 0.61 & 1.28 & 1.13 & 0.68 & 0.58 & 0.87 & 1.16 & 0.87 & 0.67 \\
\hline SM & & 3.16 & 4.68 & 4.95 & 5.02 & 3.60 & 3.71 & 4.30 & 5.01 & 5.24 & 64 & 5.91 & .11 & .71 & 6.24 & 6.01 & 5.83 \\
\hline GP-GM & & 1.03 & 1.03 & 0.78 & 0.65 & 0.85 & 0.55 & 0.66 & 0.66 & 0.94 & 1.12 & 0.85 & \begin{tabular}{|l|}
1.10 \\
\end{tabular} & 0.92 & 1.14 & 1.07 & 1.45 \\
\hline ML-1 & & 5.41 & 6.17 & 6.18 & 5.78 & 7.43 & \begin{tabular}{|l|}
6.86 \\
\end{tabular} & 5.88 & 6.26 & 8.05 & \begin{tabular}{|l|}
7.98 \\
\end{tabular} & 6.13 & 7.23 & 6.07 & 5.79 & 4.81 & 5.42 \\
\hline SP-SM & & 2.31 & 1.74 & 1.95 & 1.54 & 2.04 & 2.49 & 2.48 & 1.63 & 2.37 & 2.45 & 3.01 & 2.22 & 2.88 & 2.89 & 3.17 & 2.17 \\
\hline ML-3 & & 3.19 & 4.41 & 4.41 & 4.04 & 3.02 & 2.51 & 3.10 & 3.49 & 3.45 & 2.97 & 3.29 & 2.64 & 3.16 & 3.58 & 3.33 & 2.74 \\
\hline $\mathrm{SP}$ & & 2.45 & 2.84 & 4.16 & 4.37 & 2.22 & 2.43 & 4.61 & 1.85 & 1.44 & 23 & 2.40 & 2.12 & 2.86 & 2.18 & 1.76 & 1.37 \\
\hline $\mathrm{CH}$ & $\mathrm{FW}$ & 506 & 536 & 341 & 513 & 848 & 811 & 431 & 652 & 536 & 890 & 335 & 374 & 745 & 574 & 460 & 472 \\
\hline SM & & 2212 & 2096 & 2098 & 2134 & 2102 & 2219 & 2038 & 2051 & 1982 & 2217 & 2116 & 2258 & 108 & 2127 & 2107 & 2247 \\
\hline GP-GM & & 616 & 421 & 7 & 577 & 828 & 0 & 863 & 47 & 1163 & 73 & 1010 & 821 & 1181 & 1011 & 1180 & 817 \\
\hline ML-1 & & & & & & & & & & & & & & & & & \\
\hline SP-SM & & 990 & 747 & 2180 & 2195 & 2270 & 2107 & 2148 & 2303 & 2305 & 975 & 2238 & 2348 & 2284 & 2032 & 2286 & 2208 \\
\hline ML-3 & & 1859 & 1606 & 1928 & 1914 & 1816 & 1464 & 1379 & 1473 & 1643 & 1676 & 2026 & \begin{tabular}{|l|}
1475 \\
\end{tabular} & 2115 & 1630 & 2023 & 2042 \\
\hline $\mathrm{SP}$ & & 2089 & 2114 & 2035 & 1537 & 1948 & 1877 & 2095 & 2217 & 1733 & 1674 & 2203 & 2256 & 2019 & 2053 & 2085 & 1710 \\
\hline $\mathrm{CH}$ & DI & 85.6 & \begin{tabular}{|l|}
83.4 \\
\end{tabular} & 88.6 & 86.7 & 88.4 & 89.0 & 76.5 & 84.5 & & 84.9 & 87.4 & \begin{tabular}{|l|}
84.6 \\
\end{tabular} & & 86.9 & 85.9 & 119.5 \\
\hline SM & & 108.7 & \begin{tabular}{|l|}
111.7 \\
\end{tabular} & 105.8 & 113.6 & & 120.1 & 109.7 & 111.1 & 105.3 & 08.4 & & \begin{tabular}{|l|}
111.2 \\
\end{tabular} & 09.0 & & 105.8 & \\
\hline GP-GM & & & & & & & & & 126.0 & & & & 124.9 & & & & 126.5 \\
\hline ML-1 & & 94.4 & 95.5 & 97.9 & 97.0 & 95.9 & 96.2 & 99.0 & 98.2 & 95.6 & 97.5 & 97.2 & 97.2 & 96.3 & 8.6 & 98.2 & 96.7 \\
\hline SP-SM & & 110.3 & & & & & 100.9 & 100.8 & & & 98.9 & & 100.6 & 108.3 & & & \\
\hline ML-3 & & 87.2 & 83.4 & 74.4 & 81.3 & 75.5 & 83.2 & 82.5 & 86.6 & 77.6 & 81.6 & 83.2 & 75.4 & 81.6 & 82.6 & 87.0 & 89.5 \\
\hline $\mathrm{SP}$ & & & & & 106.1 & \begin{tabular}{|l|}
106.7 \\
\end{tabular} & \begin{tabular}{|l|}
105.7 \\
\end{tabular} & 105.9 & 106.2 & \begin{tabular}{|l|}
106.4 \\
\end{tabular} & \begin{tabular}{|l|}
106.4 \\
\end{tabular} & \begin{tabular}{|l|}
106.8 \\
\end{tabular} & \begin{tabular}{|l|}
105.1 \\
\end{tabular} & 105.9 & 105.9 & 105.9 & 106.0 \\
\hline $\mathrm{CH}$ & VB & 82.8 & 82.3 & 83.3 & 81.9 & 82.0 & 83.0 & & 85.9 & 77.4 & 80.7 & & 79.4 & 80.7 & 78.2 & 83.9 & 85.5 \\
\hline $\mathrm{SM}$ & & \begin{tabular}{|l|}
117.9 \\
\end{tabular} & \begin{tabular}{|l|}
116.1 \\
\end{tabular} & 123.6 & 117.9 & 132.9 & 130.2 & 126.8 & 119.1 & 18.2 & \begin{tabular}{|l|}
115.7 \\
\end{tabular} & 120.8 & \begin{tabular}{|l|}
110.5 \\
\end{tabular} & 23.5 & 12.6 & 17.0 & 116.9 \\
\hline GP-GM & & 123.4 & 129.7 & 123.6 & & 125.0 & 126.9 & 135.7 & 118.8 & & 130.7 & 133.3 & 117.6 & 124.7 & 127.7 & 119.1 & 113.2 \\
\hline ML-1 & & & & & 90.1 & & & & 86.8 & & & & 88.0 & & & & 130.4 \\
\hline SP-SM & & 122.1 & 124.2 & 125.1 & 122.2 & 122.1 & 124.1 & 121.6 & 122.9 & 111.6 & 115.3 & 119.9 & 112.4 & 125.8 & 132.7 & 119.9 & 126.9 \\
\hline ML-3 & & 77.6 & 94.1 & 179.8 & 185.2 & 99.4 & 91.7 & 168.5 & 179.3 & 98.8 & 98.0 & 150.1 & \begin{tabular}{|l|}
102.7 \\
\end{tabular} & 129.4 & 143.3 & 202.0 & 249.9 \\
\hline $\mathrm{SP}$ & & & & & & & & & & & & & & & & & \\
\hline
\end{tabular}

GeoGauge: This device measures the modulus of the soil at the surface of the ground. Because it requires firm contact with the ground surface, it is recommended that the device be seated in sand or other fine material prior to usage. In the medium (SP-SM) and coarse (SM) silty-sand-gravel mixtures, the GeoGauge was inconsistent in its reading and at times did not allow a recordable result. The batteries are difficult to replace in the 
unit, and the time for taking a reading can be extensive if the ground surface is not firm.

Water Balloon: This method suffered three issues that limited its field effectiveness. First, in order to properly fill the voids approximating the volume of the hole, a water pressure of approximately $3 \mathrm{psi}(20.7 \mathrm{kPa})$ is required of the inflated balloon. To maintain this pressure adequately, the user must exert constant downward force on the device. Any change in position or relaxation by the user causes the entire gauge to move, resulting in an error in the final volume measurement. Second, this pressure also exceeds the shear strength of the loose sand (SP) and silt (ML-1), causing the balloon to push the sidewalls of the hole outward and resulting in a hole volume greater than that excavated. Third, the nature of a thin-walled balloon is subject to rupture in soils containing angular particles. In several instances the balloon ruptured in the GP-GM soil. When this occurred, the water in the balloon saturated the hole, and no further testing could be conducted at that location even if the balloon had been replaced.

Moisture Density Indicator: This device suffered two issues that limited its field effectiveness. First, the manufacturer requires that a third party data acquisition unit be used to collect data from the M+DI. This led to frequent communication problems between third party hardware and vendor software, including reliability of third party hardware and incompatibility with certain operating systems. This makes use of this device frustrating to the user. Second, installation of the four rods in the seating mold causes the seating plate to become wedged into the soil surface. This wedging makes removal of the mold difficult without disturbing the rods, resulting in a loss of contact with the soil along the entire rod length, leading to a very low moisture content reading. This effect is exacerbated in soils with coarser grain sizes. The manufacturer cautions against its use in these soils, but this limitation prevents its use for broad military field scenarios. 


\section{Analysis of Field Data}

The following sections describe the qualitative and quantitative measures employed to down select the 11 studied devices to identify the best military option to replace the NDG. Factors considered were the reliability of each device to function as described by the manufacturer, precision and accuracy of each device, and the means to calibrate the device in a field setting.

\section{Device reliability}

Foremost among the requirements of any device for determining the desired compaction of soil is the assurance that the device will return meaningful values. During the field tests, notes were taken on the ease-ofuse for each device and notations were made for discarded data points. Several of the devices consistently returned an error message instead of actual data, as seen by the black cells in Table 9. Upon compiling the data from all soils, this qualitative observation was quantified by determining (1) the percentage of each device's rejected data for each soil type and (2) the average data rejection based on the 112 data point readings taken over the seven soil types. These averages were then ranked in descending order. From this ranking, a clear break point occurred at $>25$ percent, where the DFW, M+DI, and WB devices were considered highly prone to error. In contrast, the next highest average error was 10 percent for the GG device. For the purposes of QA/ QC, it is difficult to rely on an instrument that gives an average of one data error out of every four readings. Table 10 provides the percent data rejection for all the instruments in all the soil types studied.

\section{Details of device rejection based on errors}

The problem inherent with the M+DI was the insertion of the probes into the soil. Insertion of four probes into a small area within a rigid guide plate resulted in the jamming of the guide plate as it rotated into the soil. As a result, significant force was required to break the guide plate loose from the pins, resulting in a loosening of the pins in the soil. Any disruptions in continuous soil contact resulted in a moisture content reading of nearly zero percent along with dry densities that were inconsistent with the field conditions. Each of these readings was considered an outlier; as a result, the M+DI was removed from further consideration based on the large number of outliers it experienced that would limit field use. Further, the device 
Table 10. Percent data rejection for all instruments and all soil types.

\begin{tabular}{|l|l|l|l|l|l|l|l|l|}
\hline \multirow{2}{*}{ Instrument } & \multicolumn{7}{|c|}{ Data Rejection (out of 16 tests/soil) } \\
\cline { 2 - 9 } & CH & ML-1 & ML-3 & SP & SP-SC & SM & GP-GM & Average \\
\hline D-LWD & $25.0 \%$ & $100.0 \%$ & $25.0 \%$ & $25.0 \%$ & $25.0 \%$ & $25.0 \%$ & $25.0 \%$ & $35.7 \%$ \\
\hline MDI & $25.0 \%$ & $0.0 \%$ & $0.0 \%$ & $18.8 \%$ & $62.5 \%$ & $25.0 \%$ & $81.3 \%$ & $30.4 \%$ \\
\hline WB & $0.0 \%$ & $75.0 \%$ & $0.0 \%$ & $100.0 \%$ & $0.0 \%$ & $0.0 \%$ & $12.5 \%$ & $26.8 \%$ \\
\hline GG & $18.8 \%$ & $0.0 \%$ & $0.0 \%$ & $0.0 \%$ & $31.3 \%$ & $18.8 \%$ & $0.0 \%$ & $9.8 \%$ \\
\hline EDG & $0.0 \%$ & $0.0 \%$ & $0.0 \%$ & $43.8 \%$ & $0.0 \%$ & $0.0 \%$ & $0.0 \%$ & $6.3 \%$ \\
\hline Clegg & $0.0 \%$ & $25.0 \%$ & $0.0 \%$ & $0.0 \%$ & $0.0 \%$ & $0.0 \%$ & $0.0 \%$ & $3.6 \%$ \\
\hline DCP & $0.0 \%$ & $0.0 \%$ & $0.0 \%$ & $0.0 \%$ & $0.0 \%$ & $0.0 \%$ & $25.0 \%$ & $3.6 \%$ \\
\hline NDG & $0.0 \%$ & $0.0 \%$ & $0.0 \%$ & $0.0 \%$ & $6.3 \%$ & $0.0 \%$ & $0.0 \%$ & $0.9 \%$ \\
\hline SC & $0.0 \%$ & $0.0 \%$ & $0.0 \%$ & $0.0 \%$ & $0.0 \%$ & $0.0 \%$ & $6.3 \%$ & $0.9 \%$ \\
\hline Z-LWD & $0.0 \%$ & $0.0 \%$ & $0.0 \%$ & $0.0 \%$ & $0.0 \%$ & $0.0 \%$ & $0.0 \%$ & $0.0 \%$ \\
\hline SS & $0.0 \%$ & $0.0 \%$ & $0.0 \%$ & $0.0 \%$ & $0.0 \%$ & $0.0 \%$ & $0.0 \%$ & $0.0 \%$ \\
\hline SDG & $0.0 \%$ & $0.0 \%$ & $0.0 \%$ & $0.0 \%$ & $0.0 \%$ & $0.0 \%$ & $0.0 \%$ & $0.0 \%$ \\
\hline Soil Average & $5.7 \%$ & $16.7 \%$ & $2.1 \%$ & $15.6 \%$ & $10.4 \%$ & $5.7 \%$ & $12.5 \%$ & - \\
\hline
\end{tabular}

required an external, third party data acquisition system, specifically a hand-held computer that, due to the connecting wire, proved to be an unreliable system prone to failures at multiple points in the data process. These findings were consistent with past military studies on the M+DI conducted at Ft. Leonard Wood and resulted in this device's being removed from further research consideration.

The problem with the GeoGauge was that the surface modulus had very little bearing on the overall soil mass at intermediate roller passes. Past USACE research (Phillips 2005) showed that the device had an inability to adequately assess modulus in stiff soils. The current research illustrated the inability of the device to capture modulus in softer soils (i.e., those that were not subjected to compaction to a maximum density). Operationally, the GeoGauge has a flaw in the battery housing which makes replacement of the batteries a complex task. Several calls to the manufacturer were required to correct problems with simply inserting a fresh set of D-cell batteries to make the device work. Further, the front face-plate must be removed to complete the battery replacement process. These two physical limitations of the device make the GeoGauge inappropriate for military use from a reliability standpoint. 
The Dynatest lightweight falling weight deflectometer was unable to record a reading in several instances of soft soils. Any combination of base plate or drop height caused an over-ranging of the deflection gauge, resulting in a null reading. This means that its usefulness in softer soils is limited. Null readings are not an acceptable field value because interpretation of the results or the proper steps to conduct afterwards is too complex to detail. The earlier version of the device required a wired connection to a laptop computer for data acquisition, which proved to be a cumbersome task. The newer version of the device used a Bluetooth transmission to a portable hand-held computer, which made usage much easier. A wired connection, however, is necessary for most military field work in contingency environments where Bluetooth connections are disabled for security purposes. Therefore, from a functional standpoint, the DFW was considered a marginal device from a functional and outlier standpoint.

\section{Accuracy of stiffness/strength devices}

After down selecting the devices that consistently return usable data, the next step was determining how well the device would perform in a QA/QC capacity. During field testing, seven different soils were tested, at varying levels of compaction. After considerable analytical effort, it was found that no clear correlations existed between stiffness/ strength values of soil and the proctor density-moisture relationship. This is an issue that is well documented in the literature, Khoury and Zaman 2004 and Rathje et al. 2006. Typical examples of observed behavior are presented in Figures 30 and 31 for data collected with the zone falling weight (ZFW) and DCP.

The data analysis was performed by taking the raw readings from the ZFW and the DCP and performing a multiple linear regression against the dry density returned by the NDG. Regression variables considered the ZFW deflection or DCP blows per six inches; the moisture content at the point of measurement; the percent passing the \#10, \#40, and \#200 sieves; the Plastic Limit; the hammer weight; the specific gravity of the soil; and the optimum moisture content and maximum dry density of the soil. What is readily observed is that these factors allow the device of interest to distinguish easily among soil types, based on density magnitude (note the high correlation coefficient). But for a given soil, banding of the data does not allow differentiation of increasing density with passes for a given soil. The primary need for any of these devices is a sensitivity over a small range of density; but it is absent for the current external data provided the regression analysis. It is more likely that engineering performance variables such as 


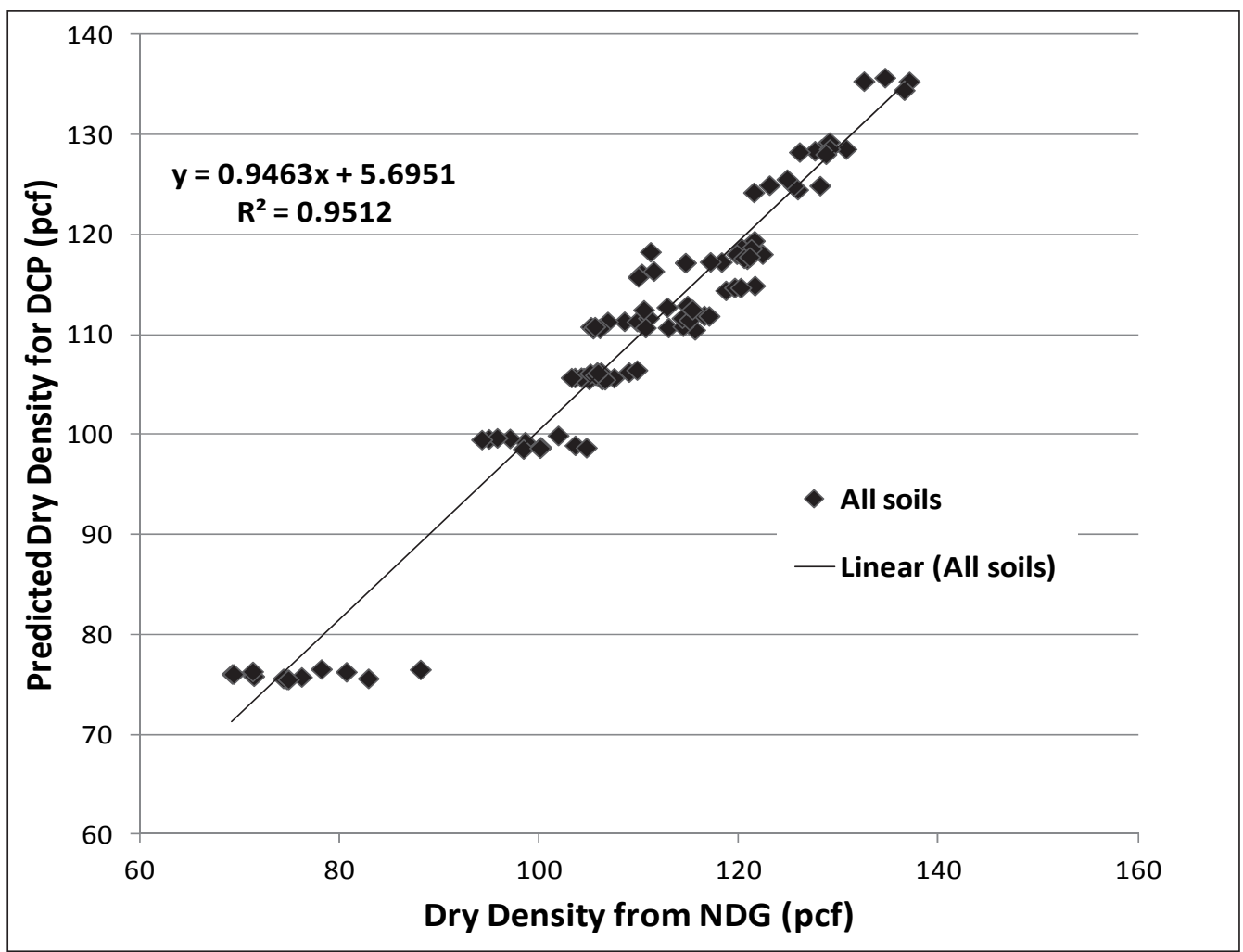

Figure 30. Dry density correlation between DCP and NDG.

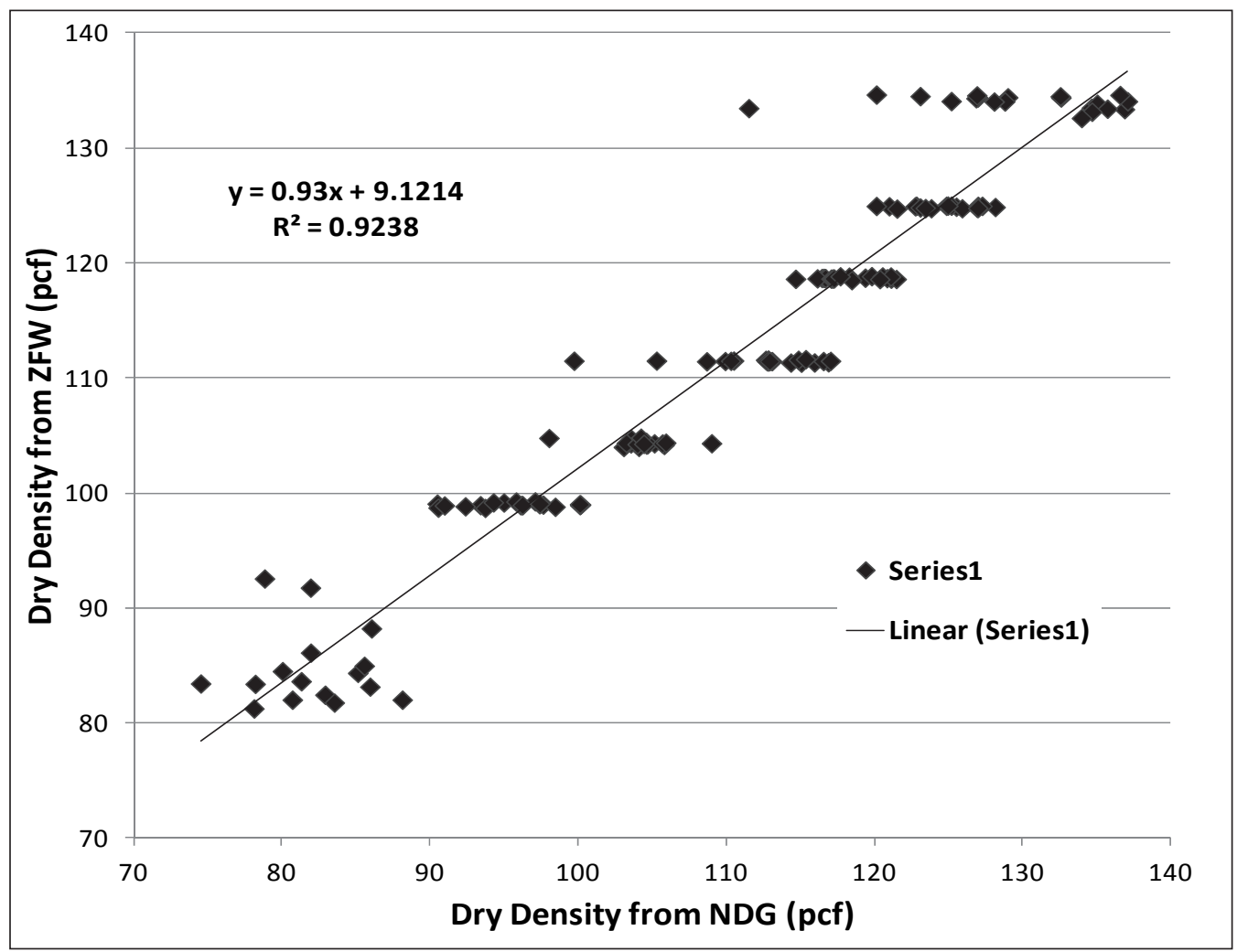

Figure 31. Dry Density comparison between ZFW and NDG. 
friction, soil suction, degree of saturation, cohesion, etc. play a significant role in the soil's response. These are values not readily available to the operator. A much deeper study of these responses is required before recommending such devices for proctor density quality control. As such, only the devices measuring the wet density of the soil are offered for sideby-side comparison to the nuclear density gauge. The raw data results for the modulus devices are shown in Appendix D.

\section{Accuracy of electrical/volume replacement devices}

Volume replacement and electrical devices provided a side-by-side comparison of moisture content, wet density, and dry density to the NDG. Device readings were not taken at the same location as the NDG results; so variance of device readings, along with the variance of the soil properties from point to point across the test section, had to be considered. Precision was based on the average deviation of the values from the nuclear gauge, and accuracy was based on the extreme spread of variation. The general flow chart for comparison and ranking of the devices is shown in Figure 32. The first step for comparing density readings was to convert all reported wet densities as dry density, shown in Equation 1 using the laboratory moisture content, not the device measured moisture content, as the reference standard.

\begin{tabular}{|c|c|c|}
\hline $\begin{array}{l}\text { Performance (percent } \\
\text { deviation from NDG) } \\
\% D E v=\frac{\gamma_{D, N D G}-\gamma_{D, D \text { wice }}}{\gamma_{D, N D G}}\end{array}$ & $\begin{array}{l}\text { Compute average } \\
\text { positive and } \\
\text { negative deviations, } \\
\text { per device and soil } \\
\text { type }(>0 \%,<0 \%)\end{array}$ & $\begin{array}{l}\text { Determine } \\
\text { maximum and } \\
\text { minimum \% } \\
\text { deviation, per } \\
\text { soil and device }\end{array}$ \\
\hline $\begin{array}{l}\text { Sum device } \\
\text { rankings for all } \\
\text { soils for } \\
\text { composite score } \\
\text { (accuracy) }\end{array}$ & $\begin{array}{c}\text { Rank density } \\
\text { devices (1 to 5) } \\
\text { for each soil type } \\
\text { by average } \\
\text { spread }\end{array}$ & $\begin{array}{l}\text { Compute spread } \\
\text { of average (high- }\end{array}$ \\
\hline $\begin{array}{l}\text { Sum device } \\
\text { rankings for all } \\
\text { soils for } \\
\text { composite score } \\
\text { (precision) }\end{array}$ & $\begin{array}{c}\text { Rank density } \\
\text { devices ( } 1 \text { to } 5 \text { ) } \\
\text { for each soil type } \\
\text { by extreme } \\
\text { spread }\end{array}$ & $\begin{array}{c}\text { of extremes } \\
\text { (max-min) }\end{array}$ \\
\hline
\end{tabular}

Figure 32. Flowchart for density device rankings. 


$$
\gamma_{\mathrm{D}}=\frac{\gamma_{\mathrm{W}}}{1-\mathrm{MC}_{\mathrm{lab}} / 100}
$$

where:

$$
\begin{aligned}
\gamma_{\mathrm{d}} & =\text { calculated dry density, pcf } \\
\gamma & =\text { reported wet density, pcf } \\
\text { MClab } & =\text { the laboratory determined moisture content (\%) }
\end{aligned}
$$

The next step in the comparison process is to determine the average positive and negative device dry density deviations from the nuclear gauge. The percent deviation was used because it would return a dimensionless performance indicator of precision. The percent deviation was calculated as follows for a given soil:

1. The percentage dry density offset of all devices from the NDG (some values were positive and some negative) was determined.

$$
\text { \% deviation }=\left(\mathrm{DD}_{\mathrm{NDG}}-\mathrm{DD}_{\text {device }}\right) /\left(\mathrm{DD}_{\mathrm{NDG}}\right)
$$

2. The average of the percent deviation of only measurements greater than the NDG reading was taken.

$$
\mathrm{AVG}_{\mathrm{HI}}=\sum(\% \text { deviation }>0 \%) / \# \text { of samples }
$$

3. The average of the percent deviation of only measurements less than the NDG reading was taken.

$$
\mathrm{AVG}_{\mathrm{LO}}=\sum(\% \text { deviation }<0 \%) / \# \text { of samples }
$$

4. An absolute difference between the average high and average lowvalues to indicate the spread in variability was taken.

$$
\text { AVGSpread }=\left|\mathrm{AVG}_{\mathrm{HI}}-\mathrm{AVG}_{\mathrm{LO}}\right|
$$

Once this range was calculated, extreme values were determined to obtain a measure of accuracy. This was accomplished by taking the largest percent deviations on the positive side and on the negative side and looking at the magnitude of the difference. 


$$
\begin{aligned}
& \% \mathrm{MAX}=\text { largest } \% \text { deviation }>0 \% \\
& \% \mathrm{MIN}=\text { largest } \% \text { deviation }<0 \% \\
& \text { Max }- \text { Min Spread }=\% \mathrm{MAX}-\% \mathrm{MIN}
\end{aligned}
$$

Based on test data presented in Table 9, Table 11, and 13, summarize the percent deviations as described above. Four unique devices -- the EDG, SC, SDG, and SS - are presented, along with a calibrated value of SDG based on the first four points taken on lift 3 after the first roller pass. This illustrates the contrast between the SDG calibrated with only grain size information versus that tuned to the dry density magnitude of the soil of interest.

Table 11. Average spread (AVGSpread) values for each device type.

\begin{tabular}{|c|c|c|c|c|c|c|}
\hline & & Device & & & & \\
\hline Test Item & Soil Type & EDG & $\mathrm{SC}$ & SDG & SS & SDG-Corr \\
\hline 1 & ML- 1 & $64.1 \%$ & $12.5 \%$ & $27.6 \%$ & $10.4 \%$ & $26.7 \%$ \\
\hline 2 & SP & $9.0 \%$ & $12.1 \%$ & $13.2 \%$ & $16.9 \%$ & $13.3 \%$ \\
\hline 3 & ML- 3 & $15.7 \%$ & $18.4 \%$ & $25.8 \%$ & $24.0 \%$ & $26.4 \%$ \\
\hline 4 & SM & $7.7 \%$ & $11.1 \%$ & $9.9 \%$ & $14.6 \%$ & $10.3 \%$ \\
\hline 5 & SP-SC & $10.5 \%$ & $10.0 \%$ & $7.7 \%$ & $33.7 \%$ & $8.0 \%$ \\
\hline 6 & $\mathrm{CH}$ & $14.1 \%$ & $43.7 \%$ & $31.7 \%$ & $51.2 \%$ & $30.4 \%$ \\
\hline 7 & GP-GM & $20.4 \%$ & $15.6 \%$ & $15.2 \%$ & $41.1 \%$ & $20.0 \%$ \\
\hline \multicolumn{2}{|c|}{ Composite Score } & $142 \%$ & $123 \%$ & $131 \%$ & $192 \%$ & $135 \%$ \\
\hline
\end{tabular}

\begin{tabular}{|c|l|c|c|c|c|c|}
\hline & & Device & & & & \\
\hline Test Item & Soil Type & EDG & SC & SDG & SS & SDG-Corr \\
\hline 1 & ML- 1 & $34.6 \%$ & $7.6 \%$ & $15.2 \%$ & $4.9 \%$ & $15.3 \%$ \\
\hline 2 & SP & $3.5 \%$ & $5.4 \%$ & $7.0 \%$ & $9.1 \%$ & $6.4 \%$ \\
\hline 3 & ML- 3 & $6.3 \%$ & $7.7 \%$ & $13.7 \%$ & $11.8 \%$ & $13.8 \%$ \\
\hline 4 & SM & $8.0 \%$ & $6.5 \%$ & $5.3 \%$ & $6.3 \%$ & $5.6 \%$ \\
\hline 5 & SP-SC & $5.4 \%$ & $8.8 \%$ & $4.0 \%$ & $26.7 \%$ & $0.8 \%$ \\
\hline 6 & CH & $8.1 \%$ & $13.8 \%$ & $18.0 \%$ & $27.2 \%$ & $7.9 \%$ \\
\hline 7 & GP-GM & $8.3 \%$ & $7.9 \%$ & $10.5 \%$ & $18.0 \%$ & $4.5 \%$ \\
\hline \multicolumn{2}{|l}{ Composite Score } & $74 \%$ & $58 \%$ & $74 \%$ & $104 \%$ & $54 \%$ \\
\hline
\end{tabular}

Table 12. Max-Min spread values for each device type.

\begin{tabular}{|c|c|c|c|c|c|c|}
\hline & & Device & & & & \\
\hline Test Item & Soil Type & EDG & $\mathrm{SC}$ & SDG & SS & SDG-Corr \\
\hline 1 & ML- 1 & 5 & 2 & 3 & 1 & 4 \\
\hline 2 & SP & 1 & 2 & 4 & 5 & 3 \\
\hline 3 & ML-3 & 1 & 2 & 4 & 3 & 5 \\
\hline 4 & SM & 5 & 4 & 1 & 3 & 2 \\
\hline 5 & SP-SC & 3 & 4 & 2 & 5 & 1 \\
\hline 6 & $\mathrm{CH}$ & 2 & 3 & 4 & 5 & 1 \\
\hline 7 & GP-GM & 3 & 2 & 4 & 5 & 1 \\
\hline \multicolumn{2}{|c|}{ Composite Score } & 20 & 19 & 22 & 27 & 17 \\
\hline
\end{tabular}

Table 13. Ranking of devices based on average spread value. 
Due to the variable nature of QA/ QC in soils, spreads in readings are more indicative of the ability of a device to present reliable data than are the absolute readings themselves. The spread for the density devices for a particular soil (average and max-min) was ranked in increasing order from 1 (best) 5 (worst). The rankings for each device for all soil types were then added to yield a composite rank for comparative analysis, as shown in Tables 13 and 14, and graphically in Figures 33 and 34 for the average spread and the max-min values, respectively. The devices with the lowest composite scores performed better for all soil types than devices with higher composite scores. Device-specific average spread data are shown in Appendix C.

Table 14. Ranking of devices based on max-min spread value.

\begin{tabular}{|c|l|c|c|c|c|c|}
\hline & & Device & & & & \\
\hline Test Item & Soil Type & EDG & SC & SDG & SS & SDG-Corr \\
\hline 1 & ML- 1 & 5 & 2 & 4 & 1 & 3 \\
\hline 2 & SP & 1 & 2 & 3 & 5 & 4 \\
\hline 3 & ML-3 & 1 & 2 & 4 & 3 & 5 \\
\hline 4 & SM & 1 & 4 & 2 & 5 & 3 \\
\hline 5 & SP-SC & 4 & 3 & 1 & 5 & 2 \\
\hline 6 & CH & 1 & 4 & 3 & 5 & 2 \\
\hline 7 & GP-GM & 4 & 2 & 1 & 5 & 3 \\
\hline \multicolumn{2}{l}{ Composite Score } & 17 & 19 & 18 & 29 & 22 \\
\hline
\end{tabular}

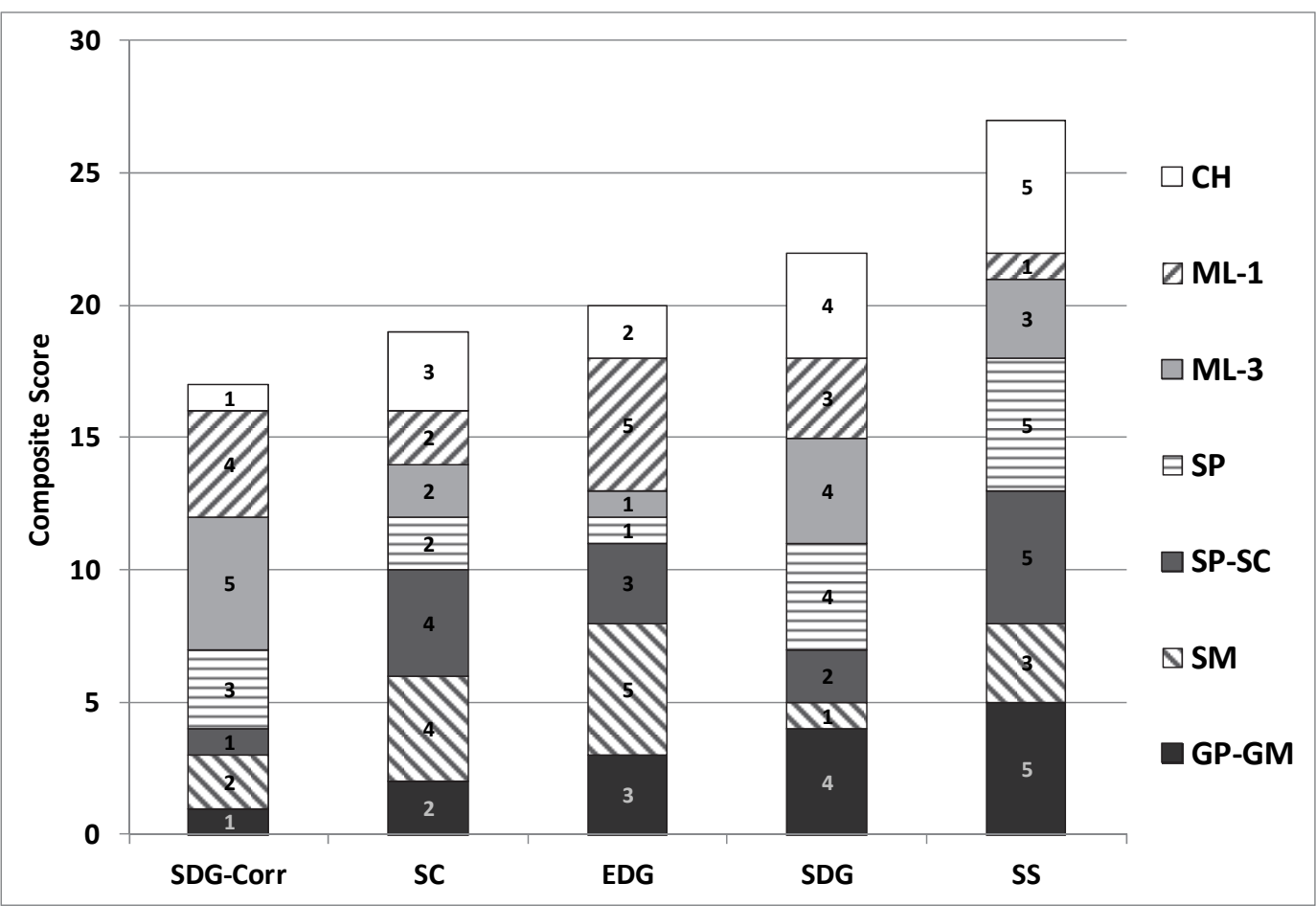

Figure 33. Average spread value overall ranking. 


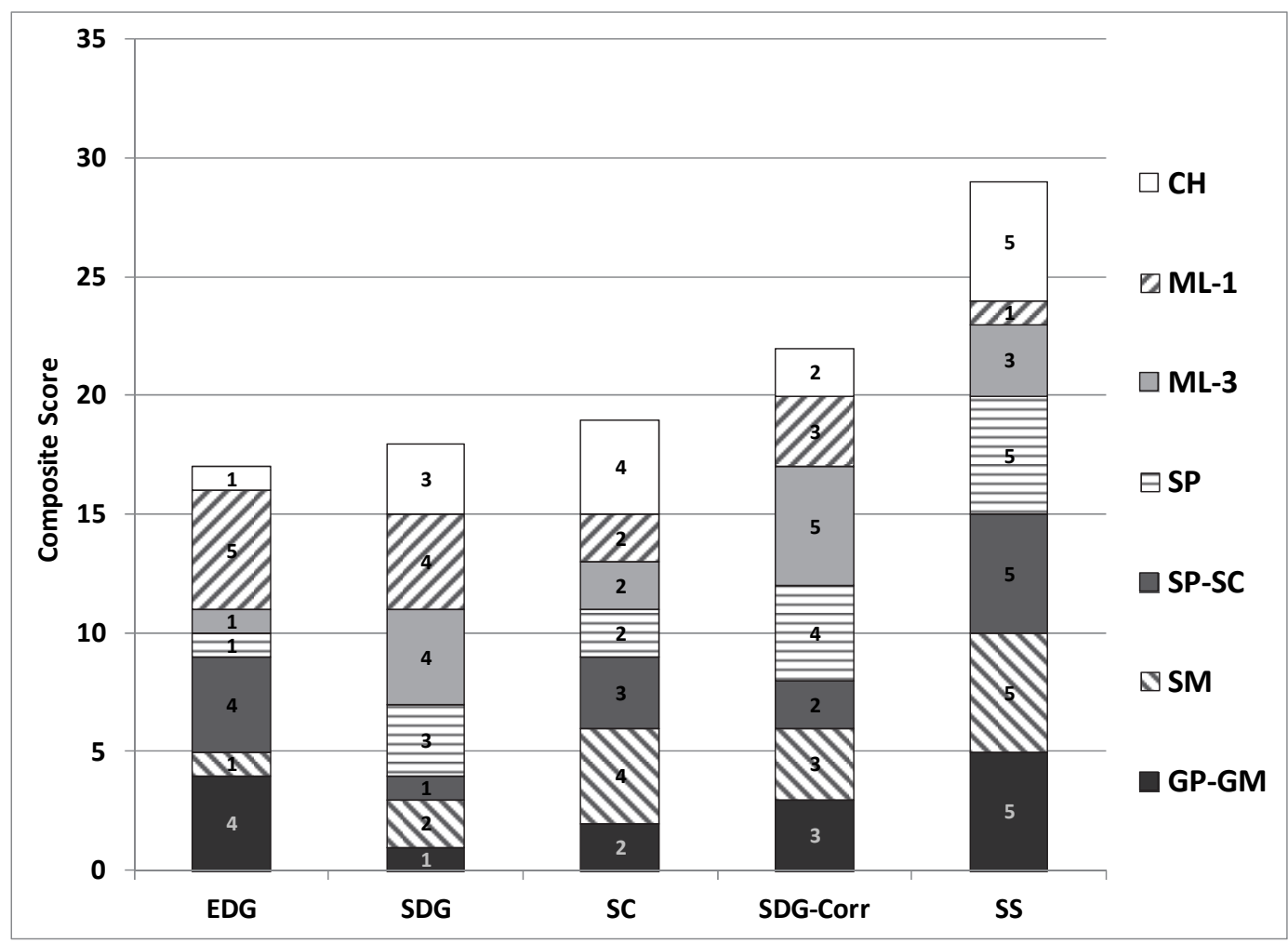

Figure 34. Maximum-minimum spread value overall ranking.

\section{Summary of device performance}

\section{Soil Density Gauge versus Electrical Density Gauge}

As can be seen, each device performed better or worse depending on the soil type tested. The SDG performed best in granular soils without plasticity, whereas the EDG performed better in the more fine-grained soils. The manufacturer of the SDG developed its platform using more granular soil types; therefore, the internal analysis routines are tuned to this type of soil response. The SDG lacks the tuning necessary to capture the density variance in wetter, more fine-grained soils. The corrected SDG device (SDGCorr) had the least variability in the average spread but had more scatter in the max-min spread. On the other hand, the EDG had the best performance in the max-min spread but was poorer in the average spread. This suggests that of the two electronic devices, (1) the SDG-Corr is closer on average to the NDG value, but can be subject to wide swings in the magnitude of the data reading and (2) the EDG maintains a more consistent level of error from one soil to the next. As noted earlier, the means by which the SDG is calibrated can affect the measured values considerably. In the max-min spread, the SDG-Corr value actually performed worse than the uncorrected value, a phenomenon attributed to the low density values selected for 
calibration. The EDG performed well and, with the exception of the ML-1 material, was quite effective. The only disadvantage of the EDG is the more complex calibration routine required to establish its accuracy, using soil prepared at varying moisture-density conditions, whereas the SDG requires only the soil prepared in the as-built condition.

\section{Sand Cone versus Steel Shot}

The sand cone (SC) was the second best overall device and deemed the best volumetric replacement device compared to the NDG. The SC worked well in most soils but had the most variability in coarser, gravelly soils.

The SS volume replacement device performed the poorest of all those tested, exhibiting the greatest overall variability in accuracy and precision. This is primarily because it is a simplification of the sand cone process, sacrificing accuracy and precision for time. In only 10-15 min, a test can be completed, whereas the sand cone requires 30-45 min and requires constant calibration and access to fresh sand. While this test is not recommended for QC/ QA events in which contractual criteria specify minimum densities, the SS test can be used when rough measures of density for contingency construction are required. The data show that this device is able to capture the density adequately for more silty-soil types (ML- 1 and ML-3), which include nearly 50 percent of the earth's landmass (Robinson et al. 1993). 


\section{Conclusions and Recommendations}

\section{Conclusions}

The following conclusions were derived from the evaluation of nonnuclear alternatives to monitoring moisture-density response in soils:

- The SDG-Corr was the best electrical device and overall had the best combination of accuracy and precision when compared to the Troxler 3440 NDG.

- The SC was the second best overall device and the best volume replacement device compared to the Troxler 3440 NDG.

- The EDG was the next best electrical device for measuring soil density, having the best precision but only average accuracy, when compared to the Troxler 3440 nuclear density gauge.

- The SS volume replacement device performed the poorest of all the devices, exhibiting the greatest overall variability in accuracy and precision.

- None of the tested strength/modulus based devices are currently able to return a value of density or moisture content, nor do they correlate with moisture and density values returned by the Troxler 3440 NDG.

\section{Recommendations}

Based on the composite rankings for both the average spread and the average spread of the maximum-minimum values, the following devices are recommended for field measurement of density:

\section{- Electrical devices}

o The SDG-Corr demonstrated the best combination of accuracy and precision when compared to the Troxler 3440 NDG. The SDG provides the best measure of accuracy but lacks precision, as evidenced by the rankings for both average spread and the average spread of the maximum-minimum values. However, the accuracy of the device is highly dependent upon proper calibration with grain size distribution and Atterberg limit properties. The SDG-Corr must be tuned to an average of two to three independent density measurements, using a device such as the sand cone. These 
calibration parameters can be quickly obtained using rapid field classification techniques, allowing a non-laboratory calibration process. This device does not work without soil property information and currently device calibration without a field sample results in poor accuracy of the device. Continued research into this device should produce better results.

o The EDG is the second best electrical device for measuring soil density. The EDG has the best precision but only average accuracy, based on comparison to the Troxler 3440 NDG. Like the SDG, the accuracy and precision of the EDG are highly dependent on proper calibration points obtained from field or laboratory data and stored in its memory. The calibration process is much more involved than that of the SDG device, and its resulting overall measurement variability is still greater than the SDG's. Field calibration of the EDG is still under study, but this process is more time intensive and complex than the SDG calibration, making it slightly less desirable than the SDG.

\section{- Volume replacement device}

- The only recommended volume replacement device for routine use in QC/ QA is the Sand Cone Density Test. The SC test is currently the reference standard for validation of the NDG (ASTM D6938-10, 2010) and requires periodic verification of wet density measurements against another standard test. The major obstacles for using the SC test are the time to conduct the testing and the variability of results depending on the operator. The SC test also consumes specialty sand during each test; hence, an adequate supply must be available for extended testing regimens. This device requires no soilspecific calibration and is able to provide accepted density values in all soil types. Unlike the NDG, the SC provides only wet density, which requires a secondary device to obtain the moisture content to produce the necessary dry density value used in soil construction QC specifications.

- The SS is not recommended at this time for routine QC/ QA testing. It is an alternative in contingency construction scenarios and should be considered an option in these low logistic efforts. 


\section{- Strength/Modulus devices}

o None of the tested strength/modulus-based devices are recommended as none of them are able to return a value of density or moisture content, nor do they correlate with moisture and density values returned by the Troxler 3440 nuclear density gauge. These devices are more ideally suited for modulus-based specifications for soil performance.

\section{Future research}

While this study was able to determine a separation in behavior for the density-based devices, future studies should focus on not only soil variability but a greater spread in prepared densities and moisture contents. The field exercises attempted to achieve such a spread, but the inherent difficulties in compacting large volumes of soil resulted in poorer density control between passes than was initially envisioned. A smaller scale laboratory effort will suffice to allow rapid preparation of a series of soils at more controlled density and moisture content levels and provide a more representative range of device responses. As well, data for each device should ideally be collected in the same location to eliminate spatial variances in soil density. This specification was absent from this exercise and resulted in analysis techniques that relied upon averaging rather than direct one-to-one comparison.

A significant amount of data collection time and analysis in this study was directed at the strength/ modulus-based devices; however, no correlations could be readily found relating device readings to the measured density. This is primarily due to the complex physical interaction of soil properties, including porosity, moisture content, mineralogy, and fabric that contribute to the modulus response. Because of the ease of use and quick data return, modulus-based devices should be considered further as alternative evaluation tools for field QC. It is recommended that future research continue to seek correlations between measurable soil physical properties and the device stiffness, perhaps even developing criteria based solely on soil stiffness and moisture content and eliminating density altogether. 


\section{References}

American Society for Testing and Materials .2010 Standard test method for in-place density and water content of soil and soil- aggregate by nuclear methods (shallow depth). Designation: D6938-10. West Conshohocken, PA: American Society for Testing and Materials.

. 2010. Standard test methods for laboratory determination of water (moisture) content of soil and rock by mass. Designation: D2216-10. West Conshohocken, PA: American Society for Testing and Materials.

. 2010. Standard test method for water content and density of soil in place by time domain reflectometry (TDR). Designation: D6780-05. West Conshohocken, PA: American Society for Testing and Materials.

2010. Standard test method for measuring stiffness and apparent modulus of soil and soil-aggregate in-place by electro-mechanical method. Designation: D6758-08. West Conshohocken, PA: American Society for Testing and Materials.

2010. Standard test method for in-place estimation of density and water content of soil and aggregate by correlation with complex impedance method. Designation: 7698. West Conshohocken, PA: American Society for Testing and Materials.

2010. Standard test method for determination of the impact value (IV) of a soil. Designation: D5874-02. West Conshohocken, PA: American Society for Testing and Materials.

2010. Standard test method for measuring deflections with a lightweight deflectometer (LWD). Designation: E-2583-07. West Conshohocken, PA: American Society for Testing and Materials.

2010. Standard test method for use of the dynamic cone penetrometer in shallow pavement applications. Designation: D6951-09. West Conshohocken, PA: American Society for Testing and Materials.

2010. Standard test method for density and unit weight of soil in place by sandcone method. Designation: D1556. West Conshohocken, PA: American Society for Testing and Materials.

2010. Standard test method for density and unit weight of soil in place by the rubber balloon method. Designation: D 2167-08. West Conshohocken, PA: American Society for Testing and Materials.

2010. Standard test method for in-place density and water content of soil and soil-aggregate by nuclear methods (shallow depth). Designation: 6938-10. West Conshohocken, PA: American Society for Testing and Materials.

. 2006. Standard test method for sieve analysis of fine and coarse aggregates. Designation: C136-06. West Conshohocken, PA: American Society for Testing and Materials. 
. 2007. Standard test method for particle-size analysis of soils. Designation:

D422-63. West Conshohocken, PA: American Society for Testing and Materials.

. 2010. Standard test methods for liquid limit, plastic limit, and plasticity index of soils. Designation: D4318-10. West Conshohocken, PA: American Society for Testing and Materials.

2012. Standard test methods for laboratory compaction characteristics of soil using standard effort. Designation: D698-12. West Conshohocken, PA: American Society for Testing and Materials.

Berney IV, E. S., J . D. Kyzar, and L. O. Oyelami. 2011. Device comparison for determining field moisture content. ERDC/ GSL TR-11-42. Vicksburg, MS: U.S. Army Engineer Research and Development Center.

Berney IV, E. S., and R.E. Wahl. 2008. A rapid soils analysis kit. ERDC/ GSL TR-08-3. Vicksburg, MS: U.S. Army Engineer Research and Development Center.

Brown, J . 2007. Non-nuclear compaction gauge comparison study. VTrans 2007-19. Montpelier, VT: Vermont Agency of Transportation.

Crovetti, J .A. 2002. Deflection-based analysis techniques for jointed concrete pavement systems. Transportation Research Record No. 1809, Washington, DC: Transportation Research Board, National Research Council.

Phillips, L. D. 2005. Field evaluation of rapid airfield assessment technologies. ERDC/ GSL TR-05-11, Vicksburg, MS: U.S. Army Engineer Research and Development Center.

Freeman, R. B., C.A. Gartrell, L. D. Wakeley, E.S. Berney, and J . R. Kelley. 2010. Steelshot method for measuring the density of soils. Canadian Geotechnical J ournal 47(11): 1299-1304. doi: 10.1139/ T10-034.

Gamache, R. W., E. Kianirad, S.Pluta, S. R. J ersey, and A.N. Alshawabkeh, 2009. A rapid field soil characterization system for construction control. Transportation Research Record: J ournal of the Transportation Research Board 617: 1-12.

J ayawickrama, P., A. Amarasiri, and P. Regino. 2000. Use of dynamic cone penetrometer to control compaction of granular fill. Transportation Research Record 1736(1): 71-80. doi: 10.3141/1736-10.

Khoury, N., and M. Zaman. 2004. Correlation between resilient modulus, moisture variation, and soil suction for subgrade soils. Transportation Research Record 1874(1): 99-107. doi: 10.3141/ 1874-11.

Lenke, L. R., R.G. McKeen, and M.P. Grush. 2003. Laboratory evaluation of GeoGauge for compaction control. Transportation Research Record: J ournal of the Transportation Research Board 1849: 20-30. doi: 10.3141/ 1849-03.

Mooney, M.A., C.S. Nocks, K.L. Selden, G.T. Bee, and C.T. Senseney. 2008. Improving quality assurance of MSE wall and bridge approach earthwork compaction. CDOT-2008-11. Denver, CO: Colorado Department of Transportation. 
Rathje, E.M., S.G. Wright, K. H. Stokoe II, A. Adams, R. Tobin and M. Salem, 2006. Evaluation of non-nuclear methods for compaction control. FHWA/TX-06/ 04835-1. College Station, TX: Texas Department of Transportation.

Robinson, J.H., and C.P. Rabalais. 1993. Performance of the combat engineer vehicle with mineplow operating worldwide and in theaters of operation. Technical Report GL-93-23. Vicksburg, MS: Waterways Experiment Station.

Sebesta, S., C. Estakhri, T. Scullion, and W. Liu. 2006. New technologies for evaluating flexible pavement construction: Year 1 report. FHWA/TX-06/ 0-4774-1. College Station, TX: Texas Department of Transportation.

Tehrani, F.S., and C. L. Meehan. 2010. "The effect of water content on lightweight deflectometer 301 measurements". Paper presented at GeoFlorida 2010: Advances in Analysis, Modeling, and Design. West Palm Beach, FL. 


\section{Appendix A: Soil Data}

\section{Silty-gravel (SM)}

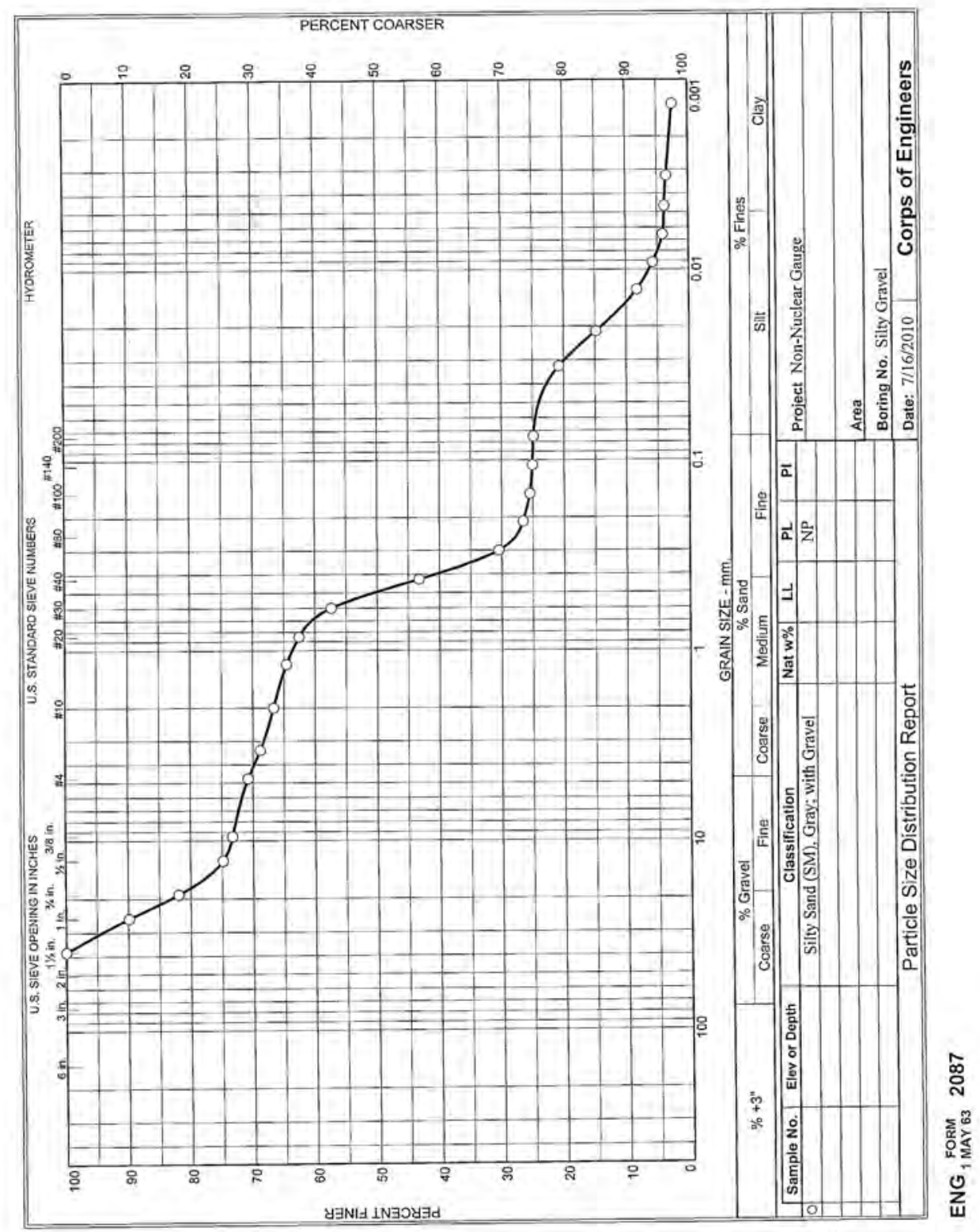




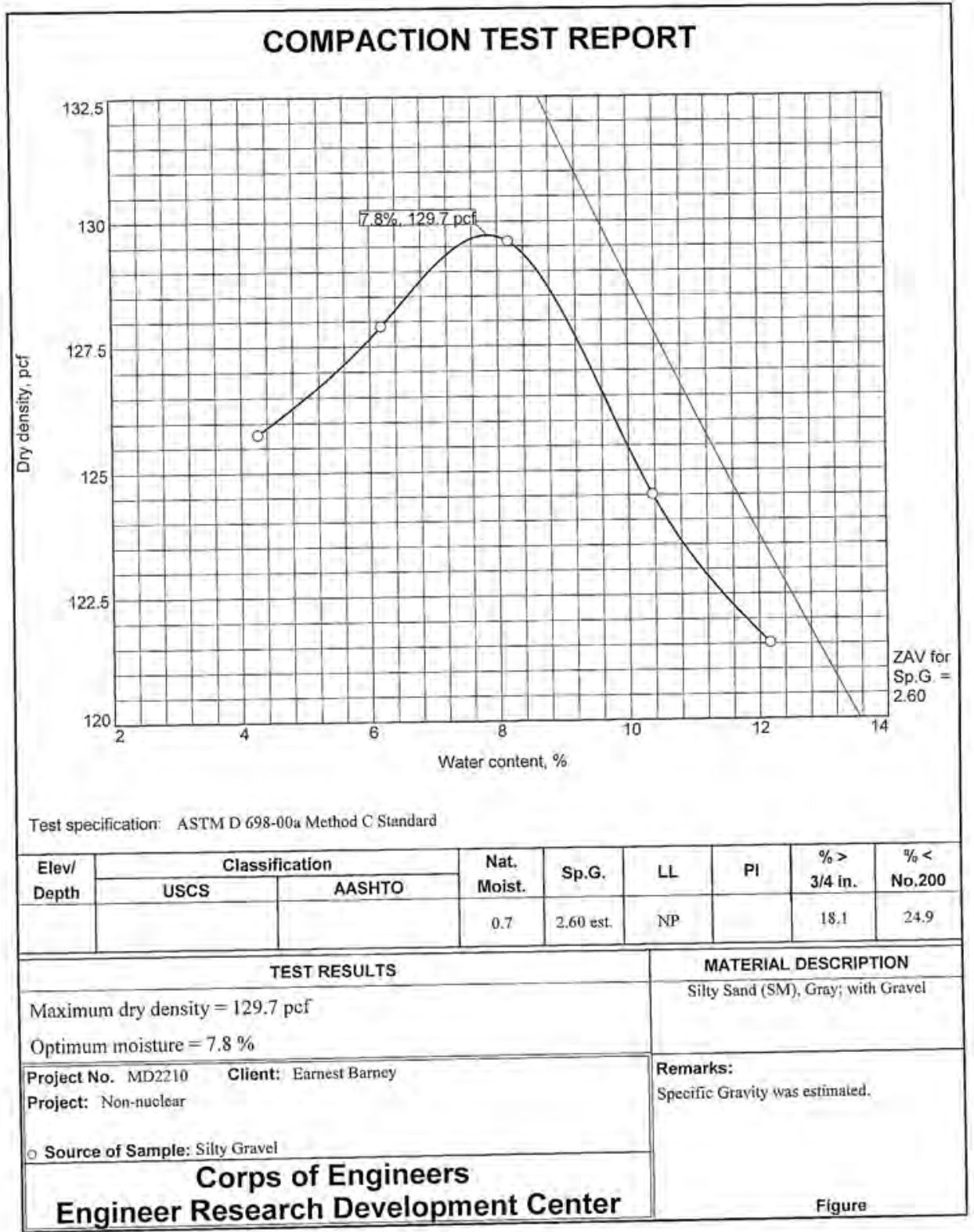

Tested By: CEC 


\section{Clay-gravel (SP-SC)}

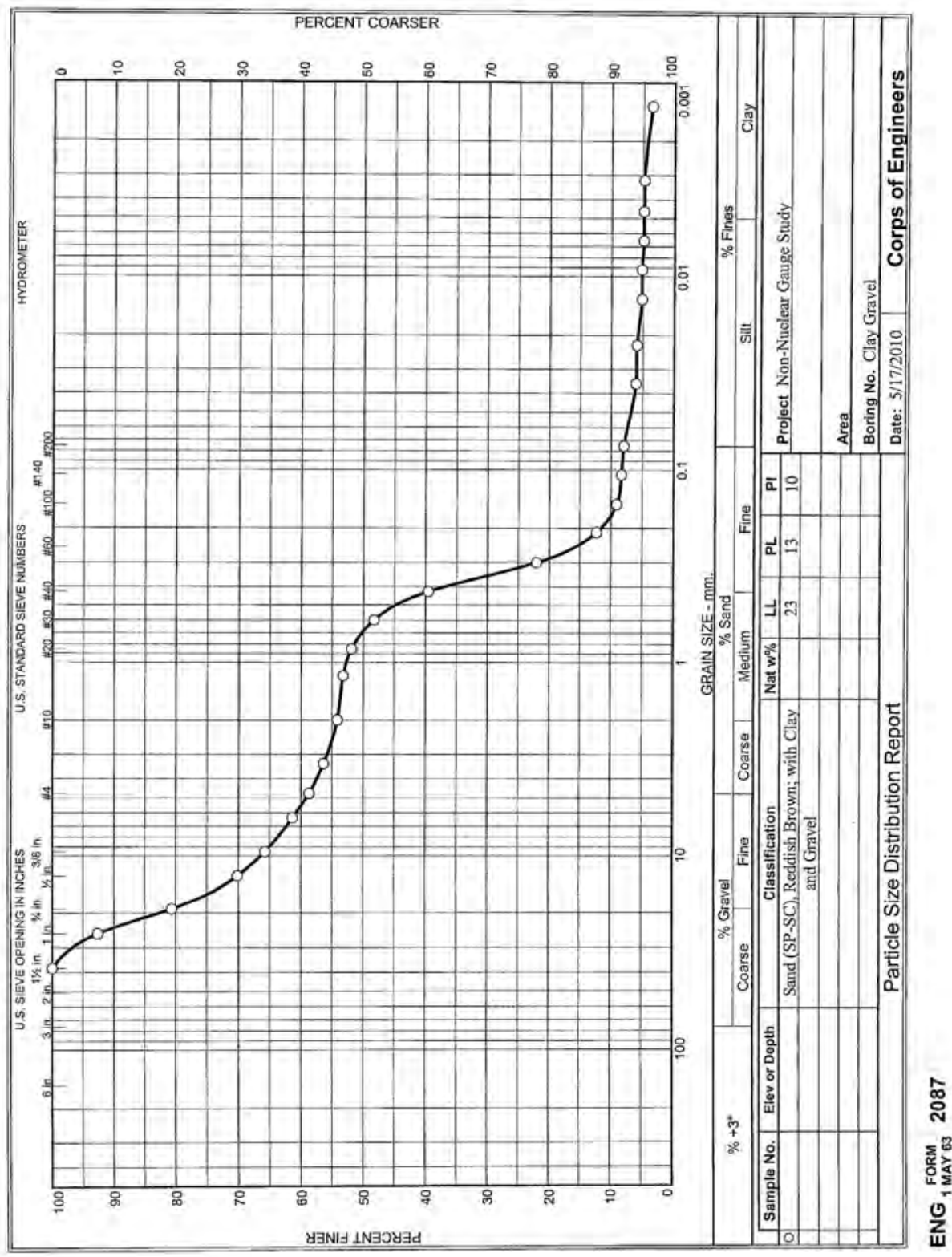




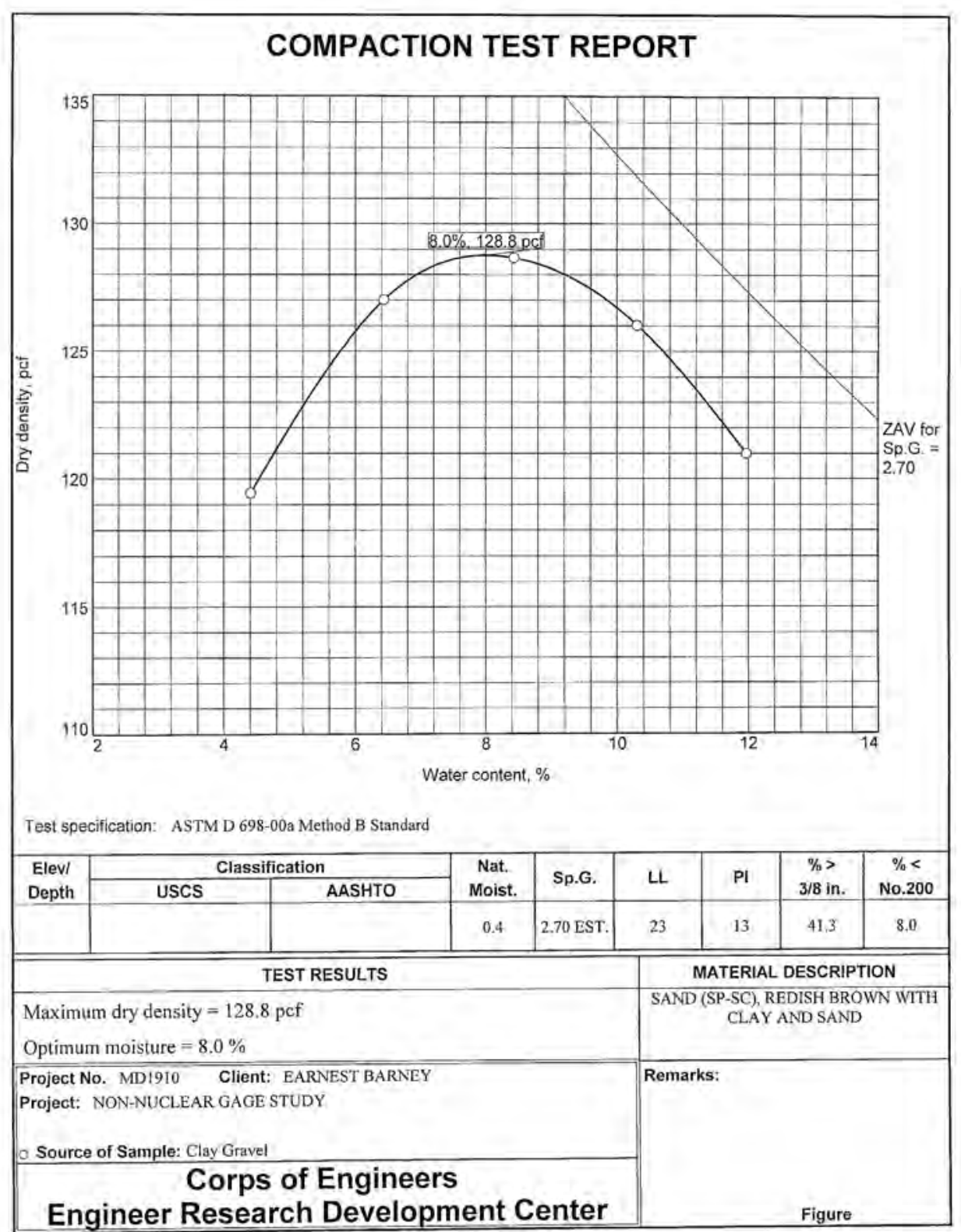

Tested By: CEC 


\section{Buckshot clay (CH)}

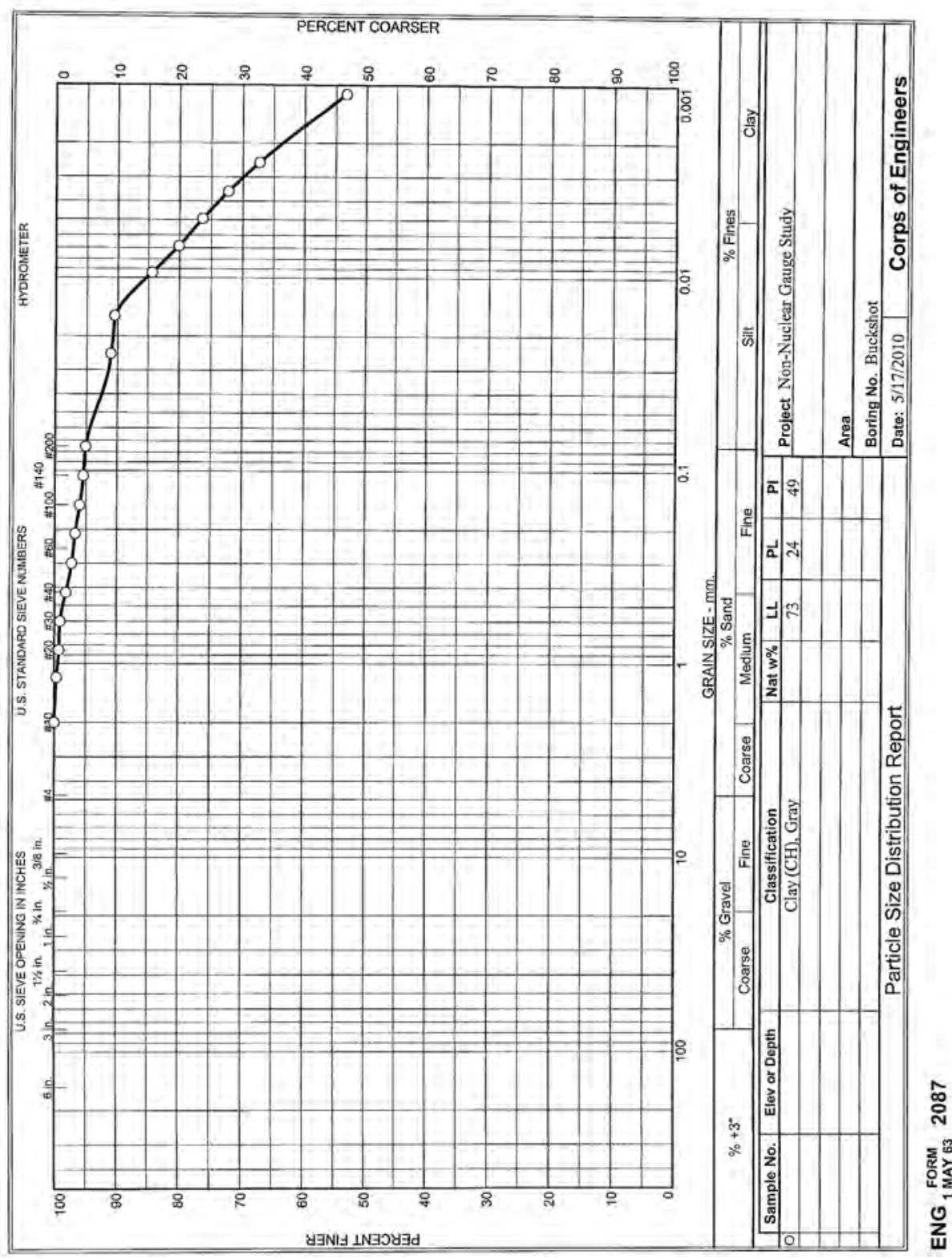




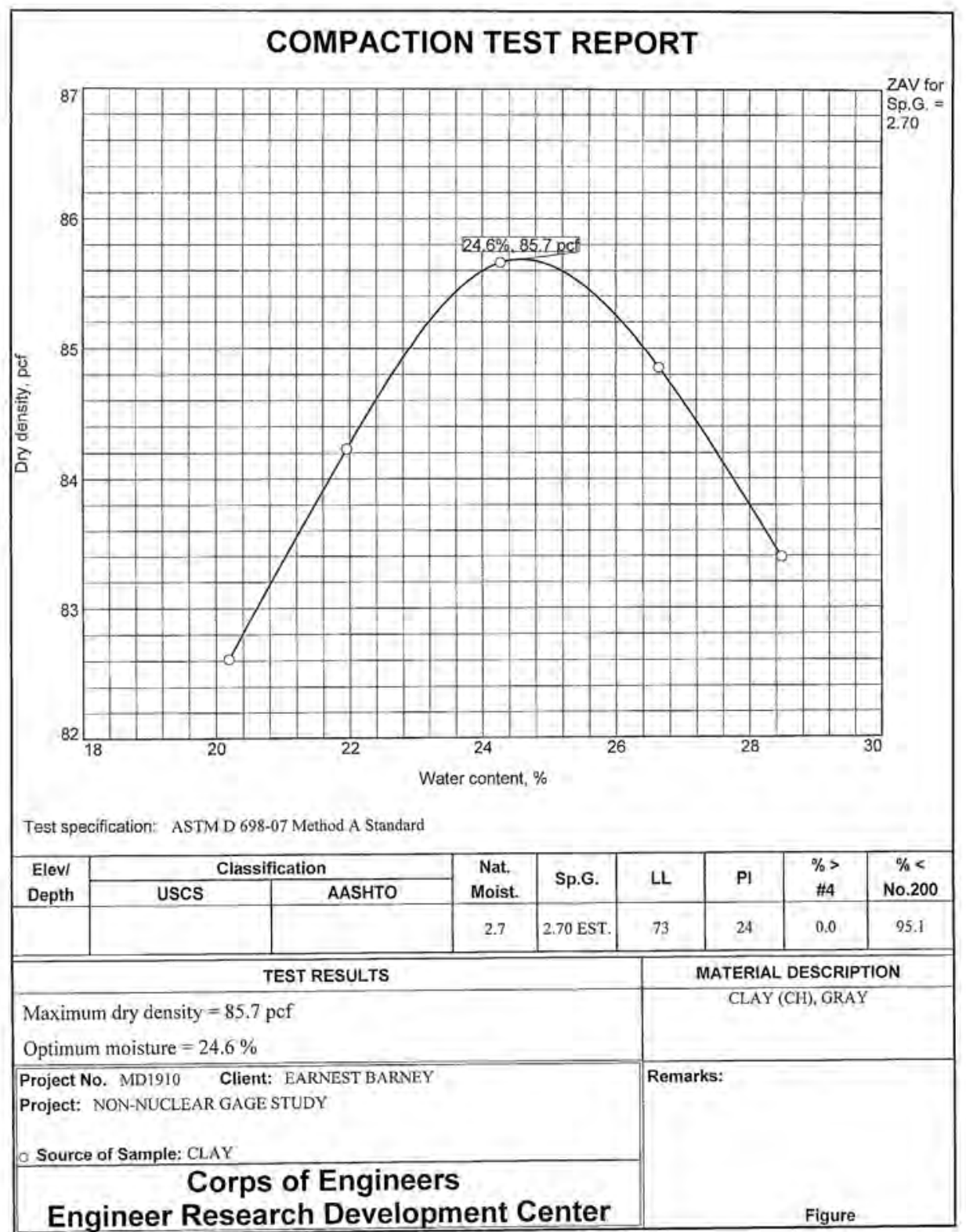

Tested By: CEC 


\section{Concrete sand (SP)}

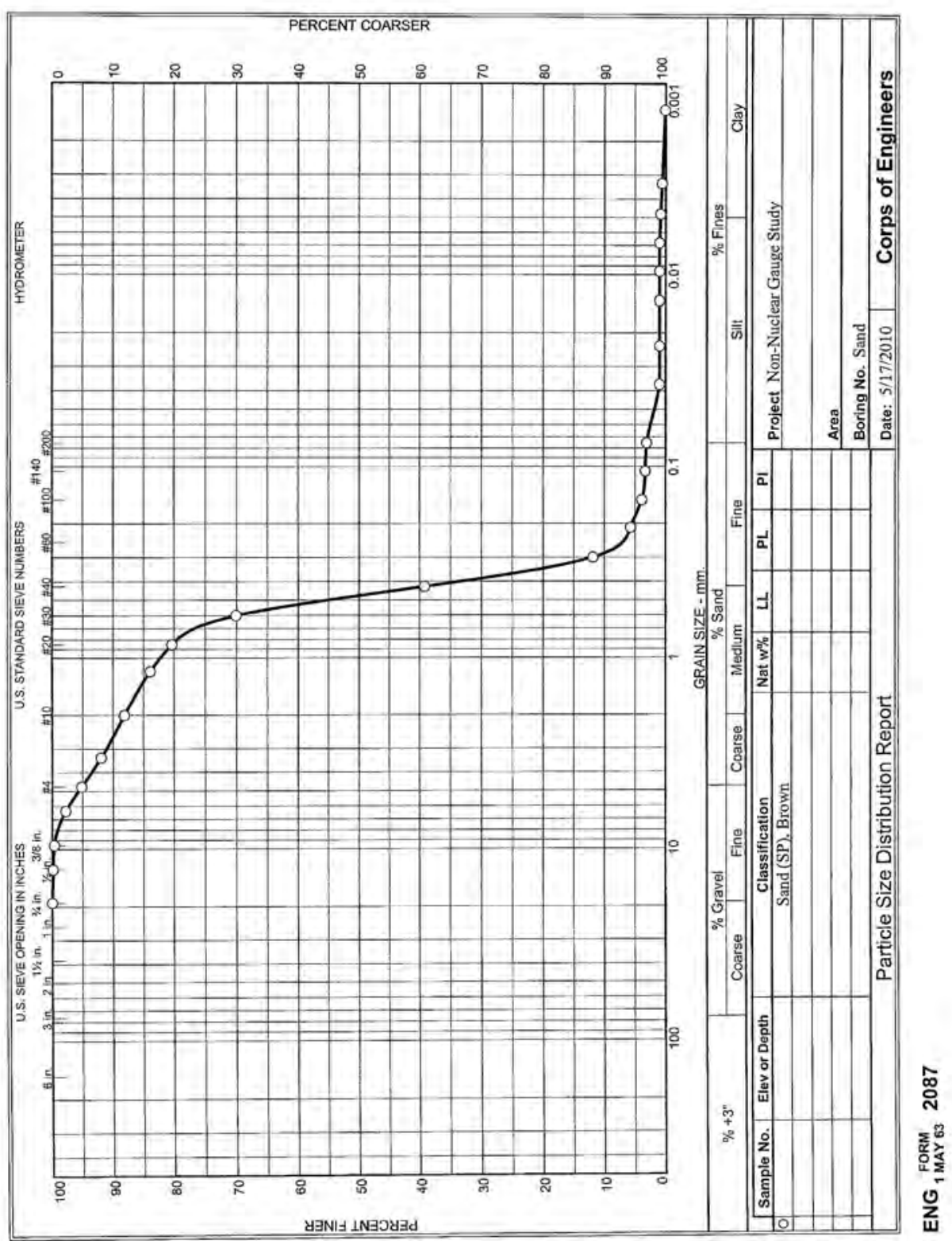




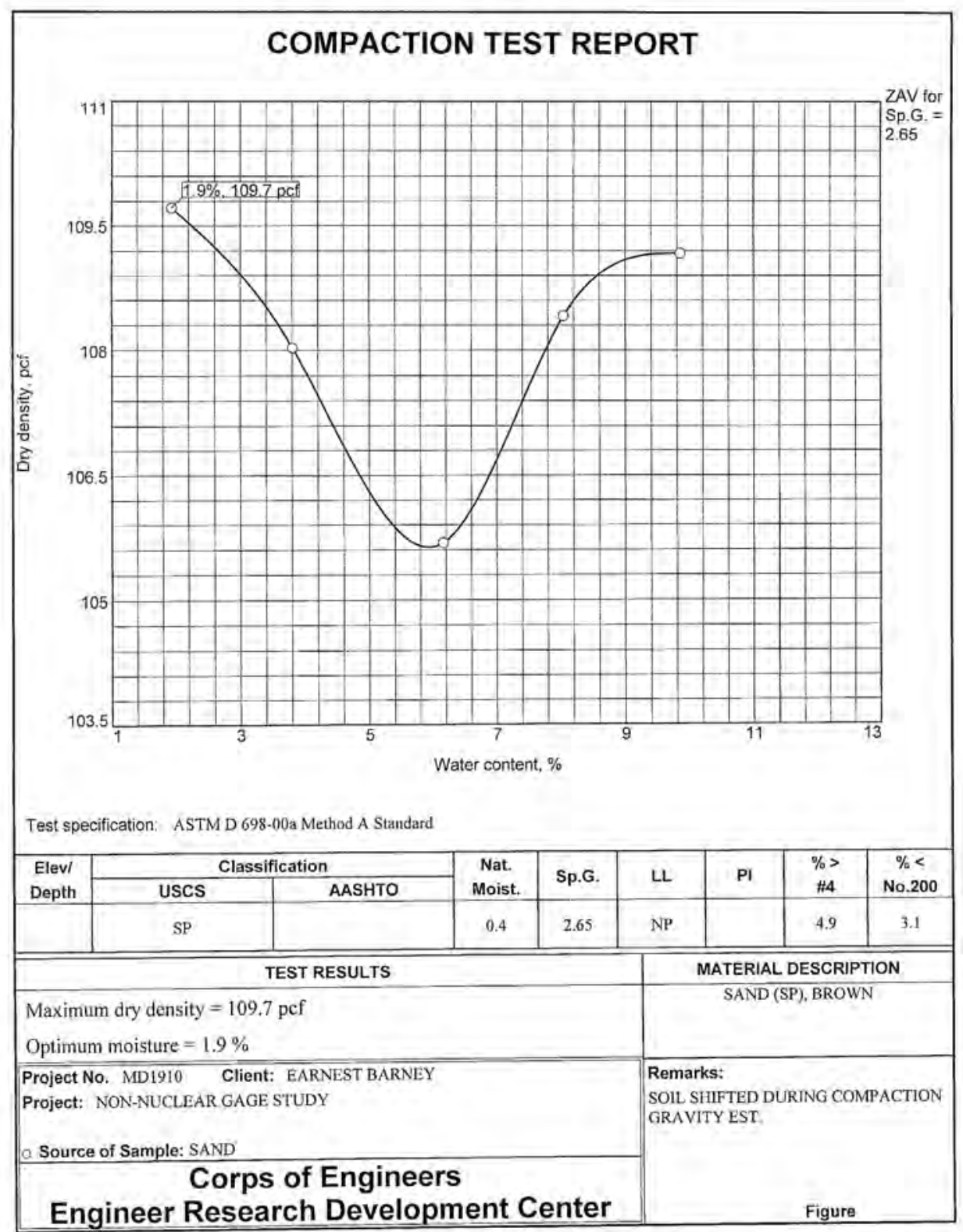

Tested By: CEC 
Crushed limestone (GP-GM)

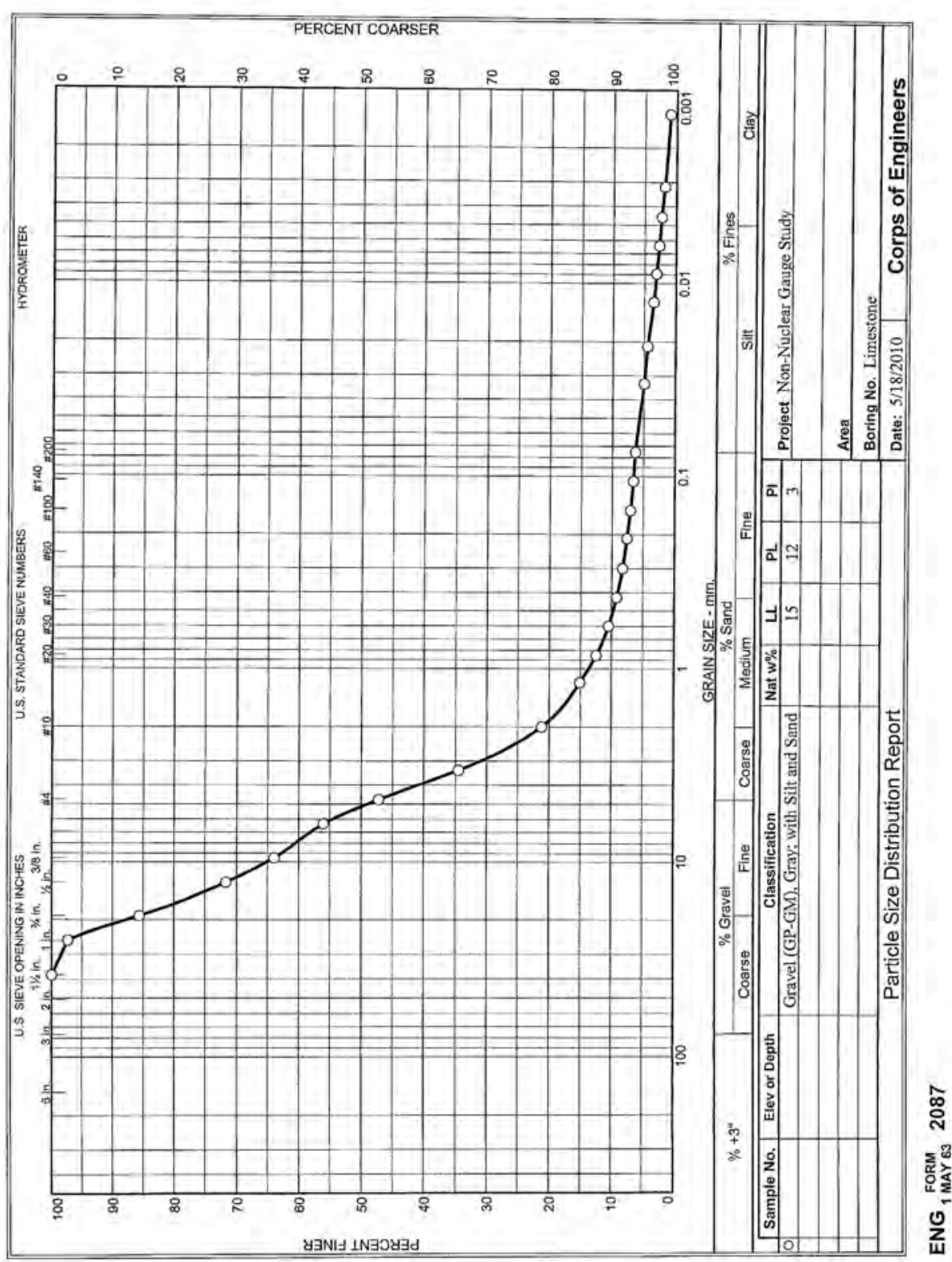




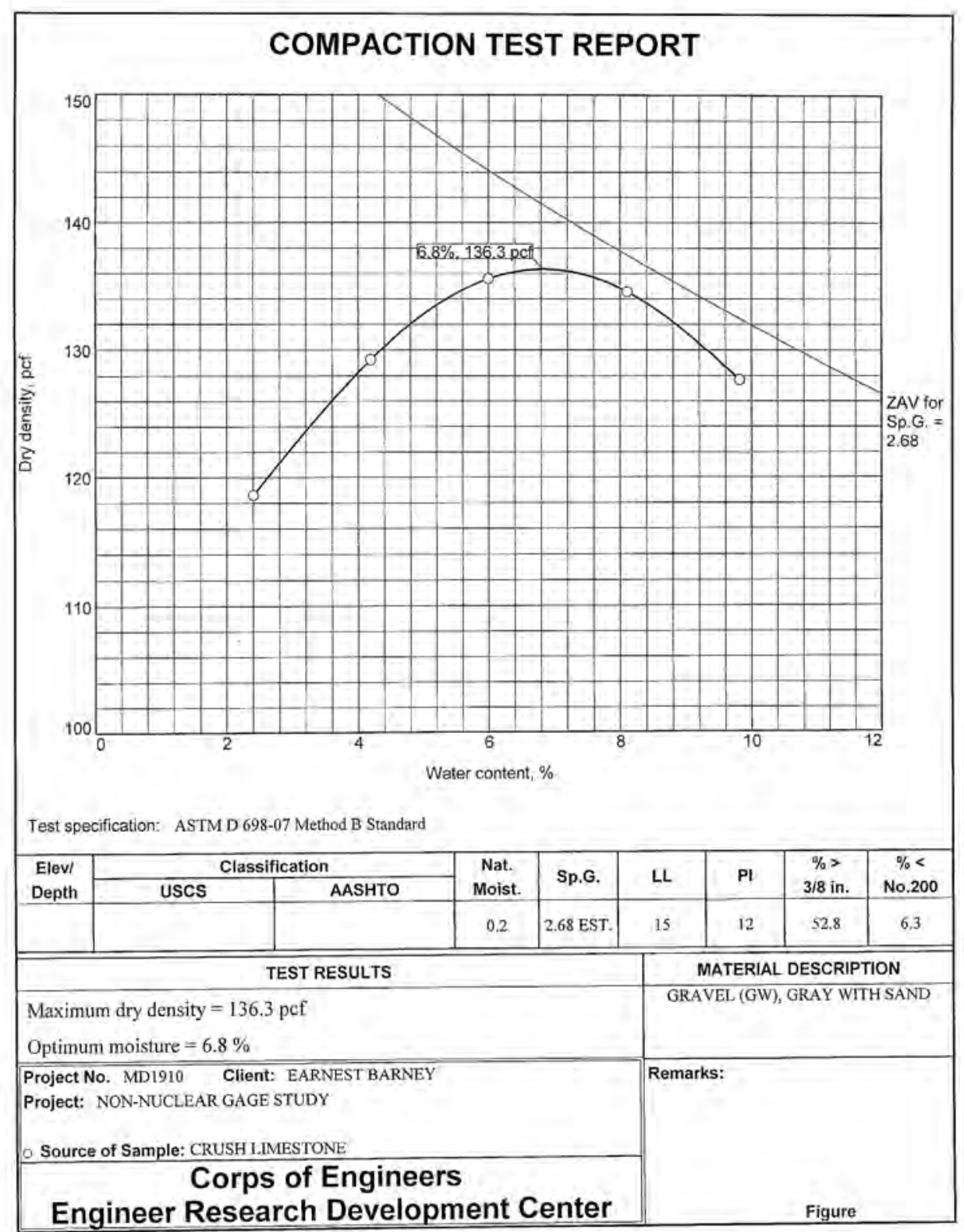

Tested By: CEC 


\section{Vicksburg loess (ML-1)}

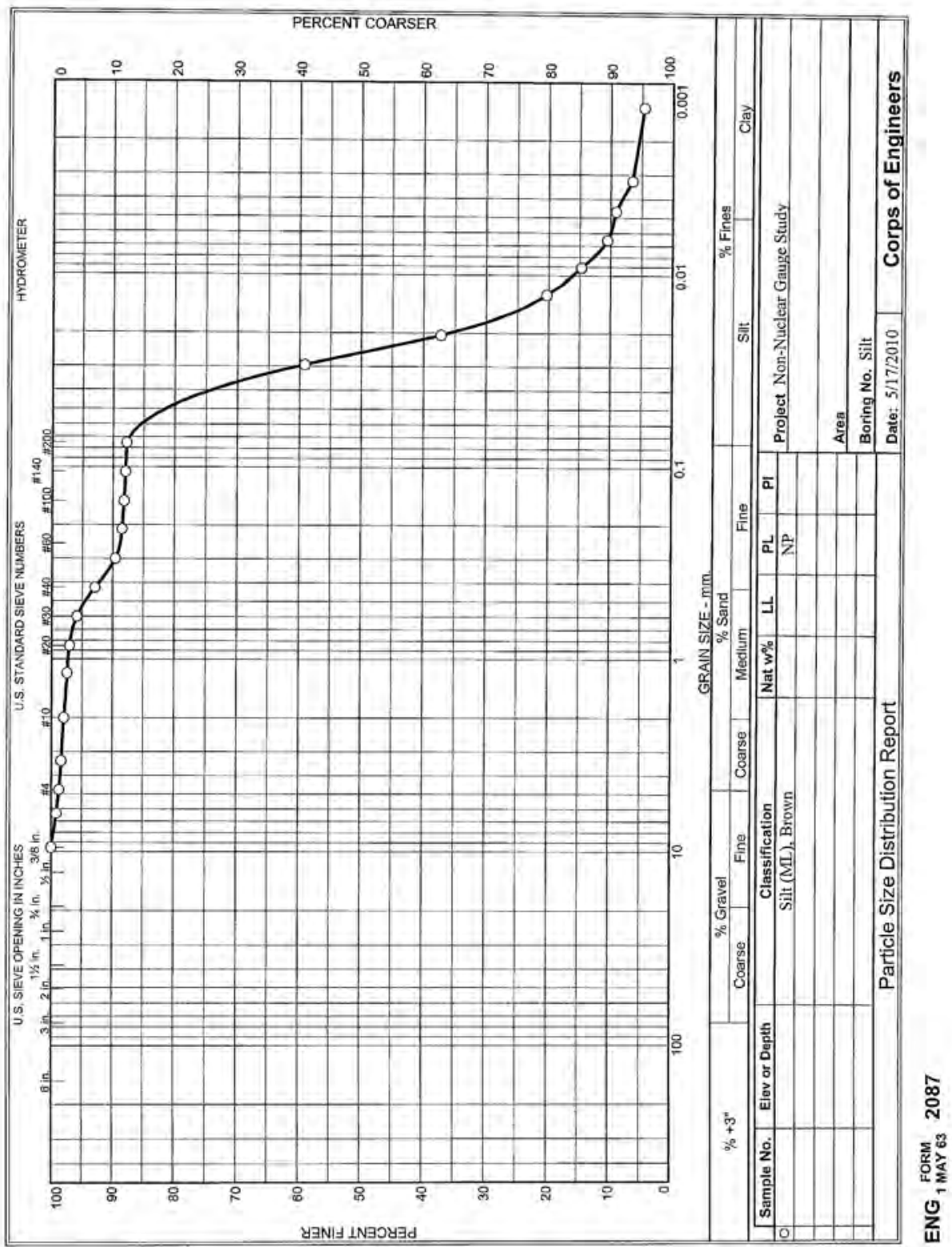




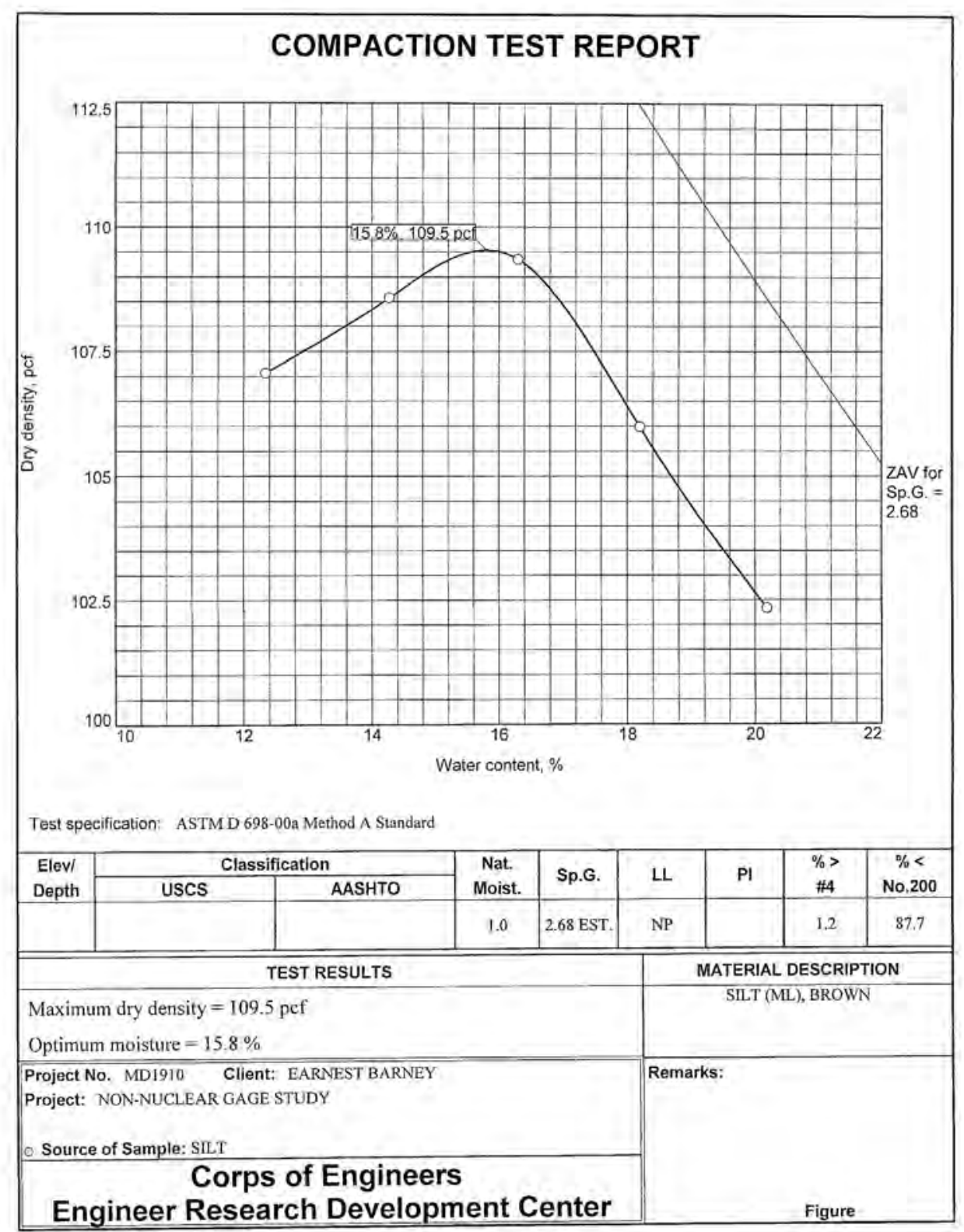

Tested By: CEC 


\section{Silty-sand (ML-3)}

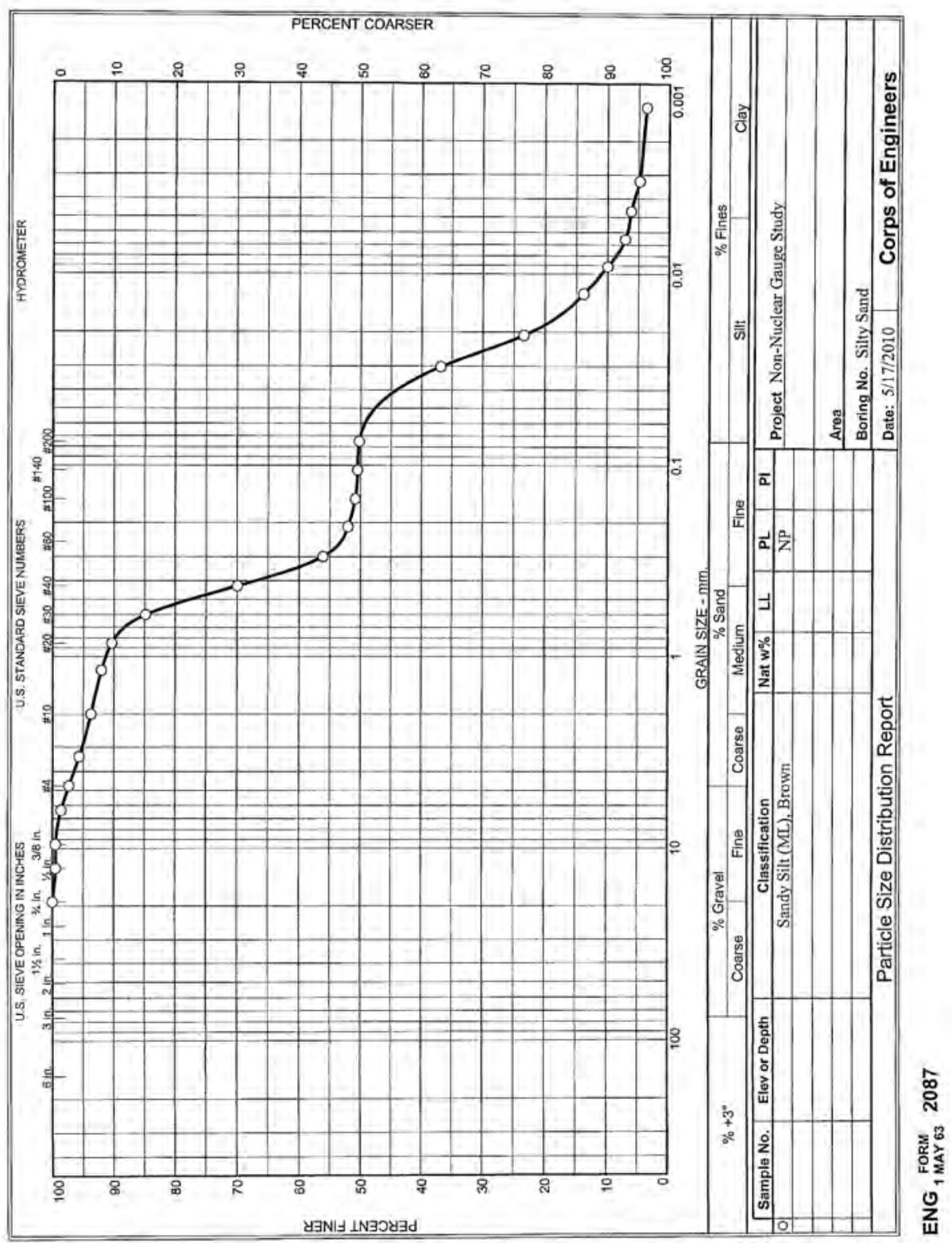




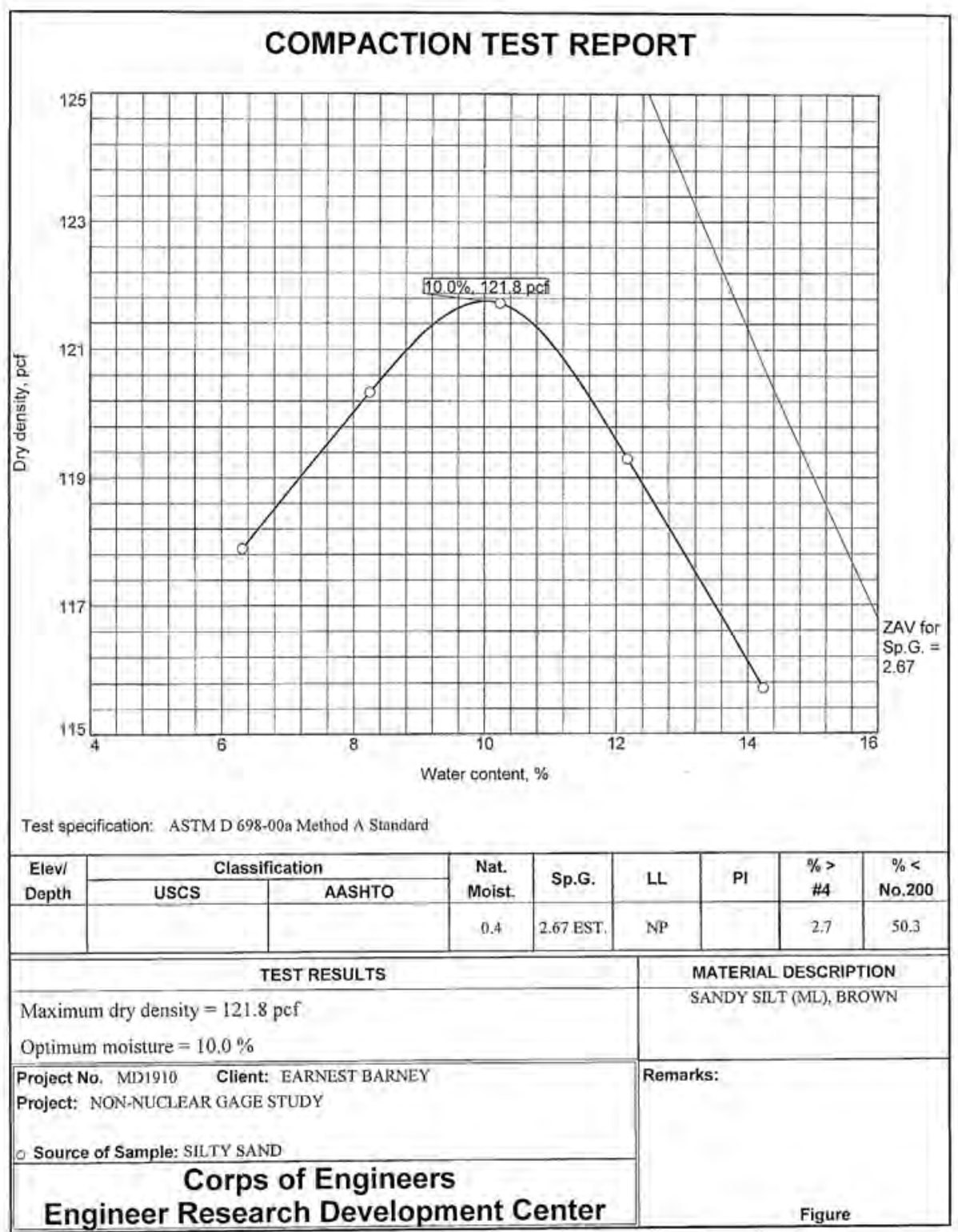

Tested By: CEC 


\section{Appendix B: Modulus Based Data}

\begin{tabular}{|l|l|l|l|}
\hline Device & Reported Value & Method & Units \\
\hline Clegg & impact value & device reading & CIV \\
\hline NDG & dry density & $\begin{array}{l}\text { from device wet density } \\
\text { and lab moisture }\end{array}$ & pcf \\
\hline DCP & blows $/ 150 \mathrm{~mm}$ & device reading & total blow count \\
\hline GG & modulus & device reading & $\begin{array}{l}\mathrm{kip} / \text { in (3 reading } \\
\text { avg) }\end{array}$ \\
\hline ZFW & deflection & device reading & $\mathrm{mm}$ \\
\hline
\end{tabular}




\begin{tabular}{|c|c|c|c|c|c|c|c|c|c|}
\hline & Section & & & 1 & & & & 2 & \\
\hline & Pass & 1 & 2 & 4 & 8 & 1 & 2 & 4 & 8 \\
\hline Soil & Device & & & & & & & & \\
\hline $\mathrm{CH}$ & NDG & 81.93 & 78.11 & 85.12 & 80.70 & 81.30 & 78.83 & 85.94 & 82.91 \\
\hline $\mathrm{CH}$ & Clegg & & 13.30 & 13.30 & 9.90 & & 13.80 & 4.00 & 8.50 \\
\hline $\mathrm{CH}$ & DCP & 8.00 & 10.00 & 12.00 & 10.00 & 10.00 & 8.00 & 10.00 & 6.00 \\
\hline $\mathrm{CH}$ & GG & 54.48 & 61.36 & 66.89 & 53.86 & 48.72 & 55.99 & 46.69 & 78.42 \\
\hline $\mathrm{CH}$ & ZFW & 1.67 & 1.35 & 0.64 & 1.63 & 0.75 & 1.62 & 0.97 & 0.61 \\
\hline ML-1 & NDG & 90.48 & 93.39 & 97.62 & 100.16 & 92.37 & 96.10 & 97.38 & 100.11 \\
\hline ML-1 & Clegg & 4.00 & 3.90 & 5.10 & & 3.70 & 5.30 & 4.20 & \\
\hline ML-1 & DCP & 4.00 & 5.00 & 5.00 & 7.00 & 3.00 & 4.00 & 5.00 & 6.00 \\
\hline ML-1 & GG & 8.67 & 9.53 & 8.82 & 9.23 & 7.96 & 9.32 & 7.43 & 8.16 \\
\hline ML-1 & ZFW & 5.41 & 6.17 & 6.18 & 5.78 & 7.43 & 6.86 & 5.88 & 6.26 \\
\hline ML-3 & NDG & 113.07 & 116.88 & 115.94 & 114.34 & 99.71 & 112.65 & 112.82 & 115.05 \\
\hline ML-3 & Clegg & 5.70 & 7.30 & 6.20 & 10.10 & 5.80 & 8.90 & 8.50 & 8.40 \\
\hline ML-3 & DCP & 8.00 & 9.00 & 10.00 & 11.00 & 6.00 & 11.00 & 8.00 & 10.00 \\
\hline ML-3 & GG & 12.27 & 10.55 & 5.89 & 7.81 & 12.65 & 9.81 & 6.58 & 9.51 \\
\hline ML-3 & ZFW & 3.19 & 4.41 & 4.41 & 4.04 & 3.02 & 2.51 & 3.10 & 3.49 \\
\hline SP & NDG & 104.60 & 105.79 & 104.08 & 104.47 & 103.54 & 104.67 & 103.06 & 103.58 \\
\hline SP & Clegg & 2.80 & 2.00 & 2.40 & 2.10 & 2.60 & 2.00 & 1.70 & 2.80 \\
\hline SP & DCP & 2.00 & 3.00 & 4.00 & 3.00 & 3.00 & 3.00 & 3.00 & 3.00 \\
\hline SP & GG & 4.26 & 4.30 & 4.46 & 4.16 & 4.17 & 4.15 & 3.80 & 4.10 \\
\hline SP & ZFW & 2.45 & 2.84 & 4.16 & 4.37 & 2.22 & 2.43 & 4.61 & 1.85 \\
\hline SP-SC & NDG & 119.36 & 116.44 & 121.11 & 120.84 & 116.57 & 116.67 & 121.46 & 118.28 \\
\hline SP-SC & Clegg & 6.00 & 7.20 & 7.90 & 12.00 & 6.00 & 7.70 & 6.80 & 10.90 \\
\hline SP-SC & DCP & 5.00 & 5.00 & 8.00 & 10.00 & 4.00 & 5.00 & 7.00 & 8.00 \\
\hline SP-SC & GG & 16.00 & 14.38 & & 12.53 & 15.75 & 13.94 & & 13.29 \\
\hline SP-SC & ZFW & 2.31 & \begin{tabular}{|l|l}
1.74 \\
\end{tabular} & 1.95 & 1.54 & 2.04 & 2.49 & 2.48 & 1.63 \\
\hline SM & NDG & 122.82 & 122.75 & 126.98 & 128.14 & 120.98 & 120.12 & 125.18 & 123.08 \\
\hline SM & Clegg & 11.00 & 11.50 & 14.60 & 8.80 & 9.10 & 9.70 & 12.30 & 11.00 \\
\hline SM & DCP & 9.00 & 8.00 & 9.00 & 11.00 & 12.00 & 9.00 & 9.00 & 11.00 \\
\hline SM & GG & & 12.92 & 1.86 & 5.58 & & 4.84 & 10.13 & 10.25 \\
\hline SM & ZFW & 3.16 & 4.68 & 4.95 & 5.02 & 3.60 & 3.71 & 4.30 & 5.01 \\
\hline GP-GM & NDG & 126.96 & 128.99 & 132.58 & 136.87 & 111.51 & 120.12 & 125.18 & 123.08 \\
\hline GP-GM & Clegg & 12.90 & 17.20 & 20.80 & 26.20 & 14.60 & 26.00 & 19.00 & 29.70 \\
\hline GP-GM & DCP & 7.00 & 7.00 & 9.00 & & 6.00 & 10.00 & 11.00 & \\
\hline GP-GM & GG & 12.19 & 14.96 & 13.30 & 14.29 & 12.93 & 16.45 & 15.21 & 15.71 \\
\hline GP-GM & ZFW & 1.03 & 1.03 & 0.78 & 0.65 & 0.85 & 0.55 & 0.66 & 0.66 \\
\hline
\end{tabular}




\begin{tabular}{|c|c|c|c|c|c|c|c|c|c|}
\hline & \multirow{2}{*}{$\begin{array}{c}\text { Section } \\
\text { Pass }\end{array}$} & \multicolumn{4}{|c|}{3} & \multicolumn{4}{|c|}{4} \\
\hline & & 1 & 2 & 4 & 8 & 1 & 2 & 4 & 8 \\
\hline Soil & Device & & & & & & & & \\
\hline $\mathrm{CH}$ & NDG & 80.03 & 74.51 & 85.56 & 78.20 & 81.94 & 83.53 & 86.04 & 88.12 \\
\hline $\mathrm{CH}$ & Clegg & & 9.90 & 9.30 & 4.90 & & 9.90 & 9.30 & 4.90 \\
\hline $\mathrm{CH}$ & DCP & 8.00 & 8.00 & 8.00 & 9.00 & 9.00 & 10.00 & 12.00 & 12.00 \\
\hline $\mathrm{CH}$ & GG & 55.47 & 51.73 & 48.15 & 49.57 & 68.72 & 53.33 & 68.54 & 59.99 \\
\hline $\mathrm{CH}$ & ZFW & 1.28 & 1.13 & 0.68 & 0.58 & 0.87 & 1.16 & 0.87 & 0.67 \\
\hline ML-1 & NDG & 90.54 & 93.71 & 96.19 & 98.44 & 90.97 & 96.23 & 97.40 & 100.10 \\
\hline ML-1 & Clegg & 3.20 & 3.90 & 4.20 & & 3.20 & 3.90 & 4.20 & \\
\hline ML-1 & $\mathrm{DCP}$ & 3.00 & 4.00 & 5.00 & 6.00 & 3.00 & 7.00 & 6.00 & 6.00 \\
\hline ML-1 & GG & 7.95 & 8.59 & 8.64 & 8.21 & 7.91 & 8.21 & 7.40 & 7.31 \\
\hline ML-1 & ZFW & 8.05 & 7.98 & 6.13 & 7.23 & 6.07 & 5.79 & 4.81 & 5.42 \\
\hline ML-3 & NDG & 108.67 & 109.91 & 112.74 & 116.54 & 105.28 & 112.92 & 110.30 & 117.03 \\
\hline ML-3 & Clegg & 9.80 & 10.80 & 8.50 & 9.30 & 9.80 & 10.80 & 8.50 & 9.30 \\
\hline ML-3 & DCP & 8.00 & 6.00 & 8.00 & 12.00 & 5.00 & 7.00 & 7.00 & 12.00 \\
\hline ML-3 & GG & 13.12 & 9.56 & 8.44 & 11.17 & 12.49 & 9.21 & 8.15 & 10.64 \\
\hline ML-3 & ZFW & 3.45 & 2.97 & 3.29 & 2.64 & 3.16 & 3.58 & 3.33 & 2.74 \\
\hline $\mathrm{SP}$ & NDG & 104.58 & 104.02 & 103.98 & 104.23 & 103.92 & 104.42 & 109.00 & 98.02 \\
\hline SP & Clegg & 3.10 & 1.80 & 1.70 & 2.60 & 3.10 & 1.80 & 1.70 & 2.60 \\
\hline SP & $\mathrm{DCP}$ & 2.00 & 2.00 & 2.00 & 3.00 & 2.00 & 3.00 & 3.00 & 4.00 \\
\hline SP & GG & 3.95 & 3.97 & 4.71 & 4.08 & 4.18 & 4.04 & 4.29 & 4.31 \\
\hline SP & ZFW & 1.44 & 2.23 & 2.40 & 2.12 & 2.86 & 2.18 & 1.76 & 1.37 \\
\hline SP-SC & NDG & 116.13 & 117.06 & 118.45 & 117.16 & 117.25 & & 120.35 & 114.67 \\
\hline SP-SC & Clegg & 7.60 & 8.80 & 6.20 & 10.50 & 7.60 & 8.80 & 6.20 & 10.50 \\
\hline SP-SC & DCP & 4.00 & 6.00 & 6.00 & 8.00 & 4.00 & 6.00 & 10.00 & 7.00 \\
\hline SP-SC & GG & 12.50 & 13.26 & & 12.98 & 12.90 & & & 12.16 \\
\hline SP-SC & ZFW & 2.37 & 2.45 & 3.01 & 2.22 & 2.88 & 2.89 & 3.17 & 2.17 \\
\hline SM & NDG & 127.26 & 123.82 & 126.91 & 125.90 & 124.95 & 126.97 & 123.43 & 121.51 \\
\hline SM & Clegg & 9.10 & 5.30 & 7.20 & 8.30 & 9.10 & 5.30 & 7.20 & 8.30 \\
\hline SM & DCP & 15.00 & 8.00 & 6.00 & 8.00 & 7.00 & 7.00 & 6.00 & 7.00 \\
\hline SM & GG & 24.44 & 2.93 & 2.42 & 2.95 & 24.11 & & 3.72 & 2.15 \\
\hline SM & ZFW & 5.24 & 6.64 & 5.91 & 6.11 & 4.71 & \begin{tabular}{|l|}
6.24 \\
\end{tabular} & 6.01 & 5.83 \\
\hline GP-GM & NDG & 128.79 & 128.08 & 135.03 & 135.71 & 126.85 & 126.91 & 134.67 & 133.97 \\
\hline GP-GM & Clegg & 17.00 & 16.00 & 18.70 & 23.80 & 17.00 & 16.00 & 18.70 & 23.80 \\
\hline GP-GM & DCP & 4.00 & 7.00 & 8.00 & & 6.00 & 6.00 & 12.00 & \\
\hline GP-GM & $\mathrm{GG}$ & 14.01 & 15.05 & 13.87 & 12.75 & 13.44 & 14.61 & 13.07 & 14.42 \\
\hline GP-GM & ZFW & 0.94 & 1.12 & 0.85 & 1.10 & 0.92 & 1.14 & 1.07 & 1.45 \\
\hline
\end{tabular}




\section{Appendix C: Data Spread for Each Device}

Spread values for each device by soil type in order of increasing grain size (CH, ML-1, ML-3, SP, SP-SC, SM, GP-GM)

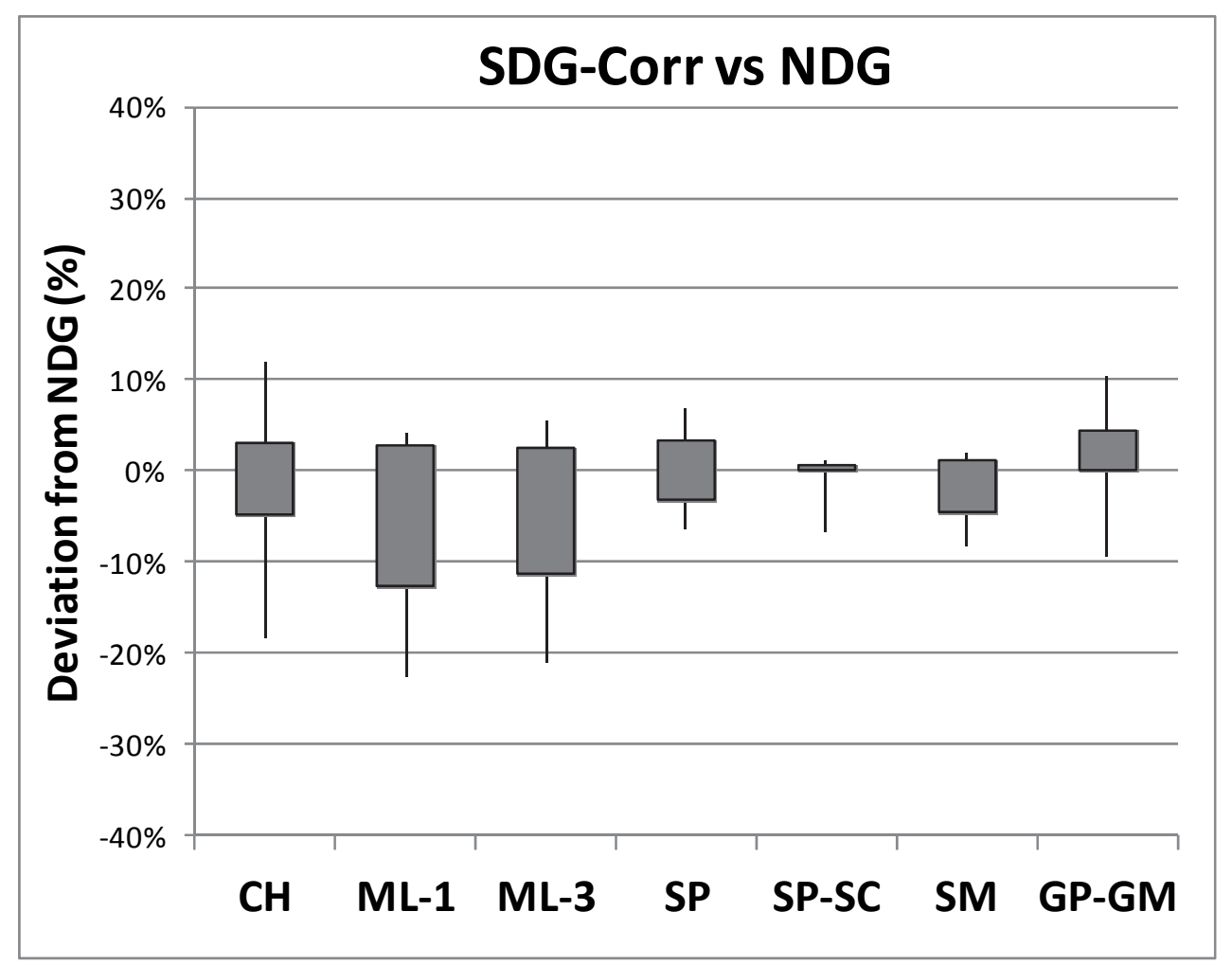



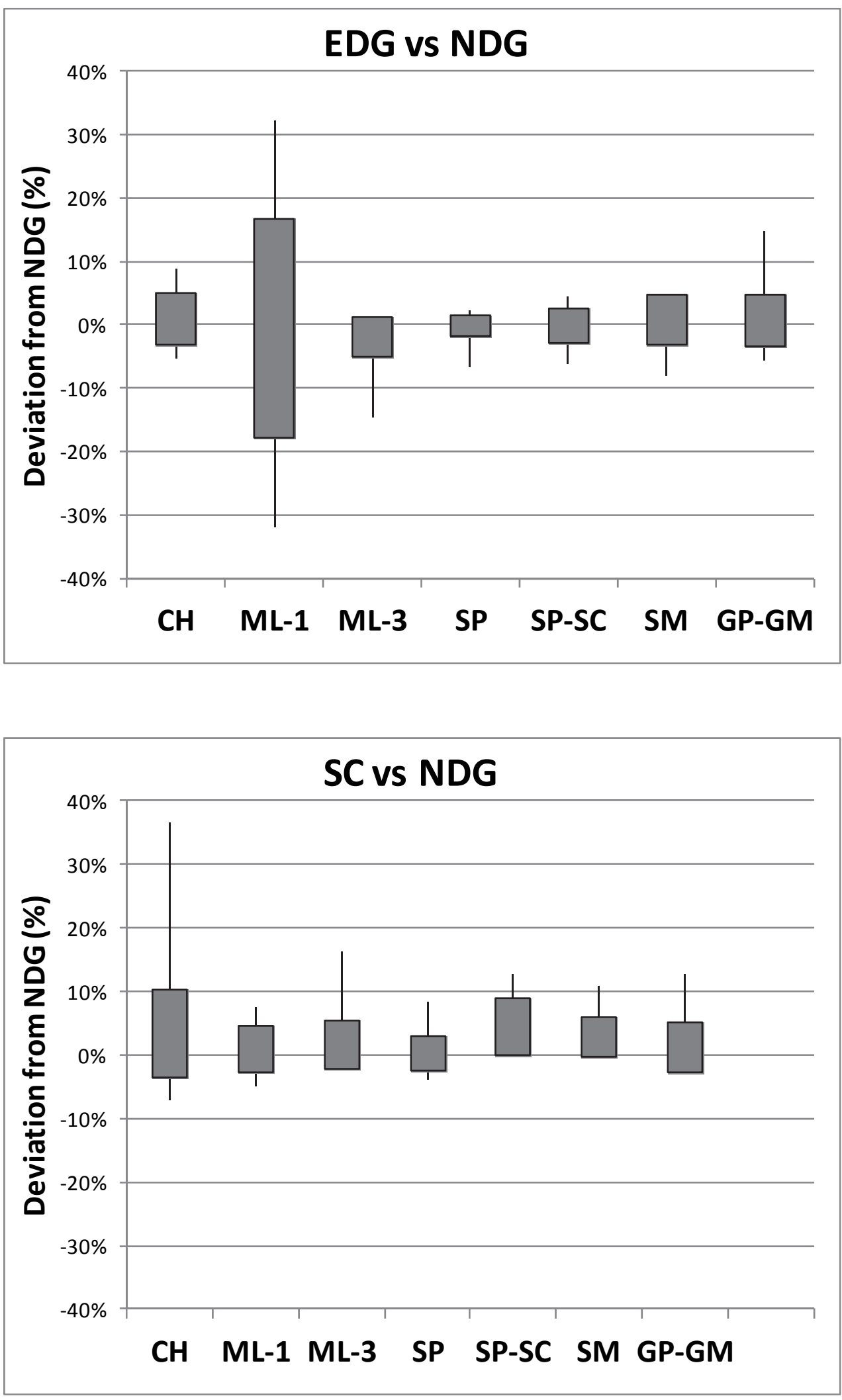

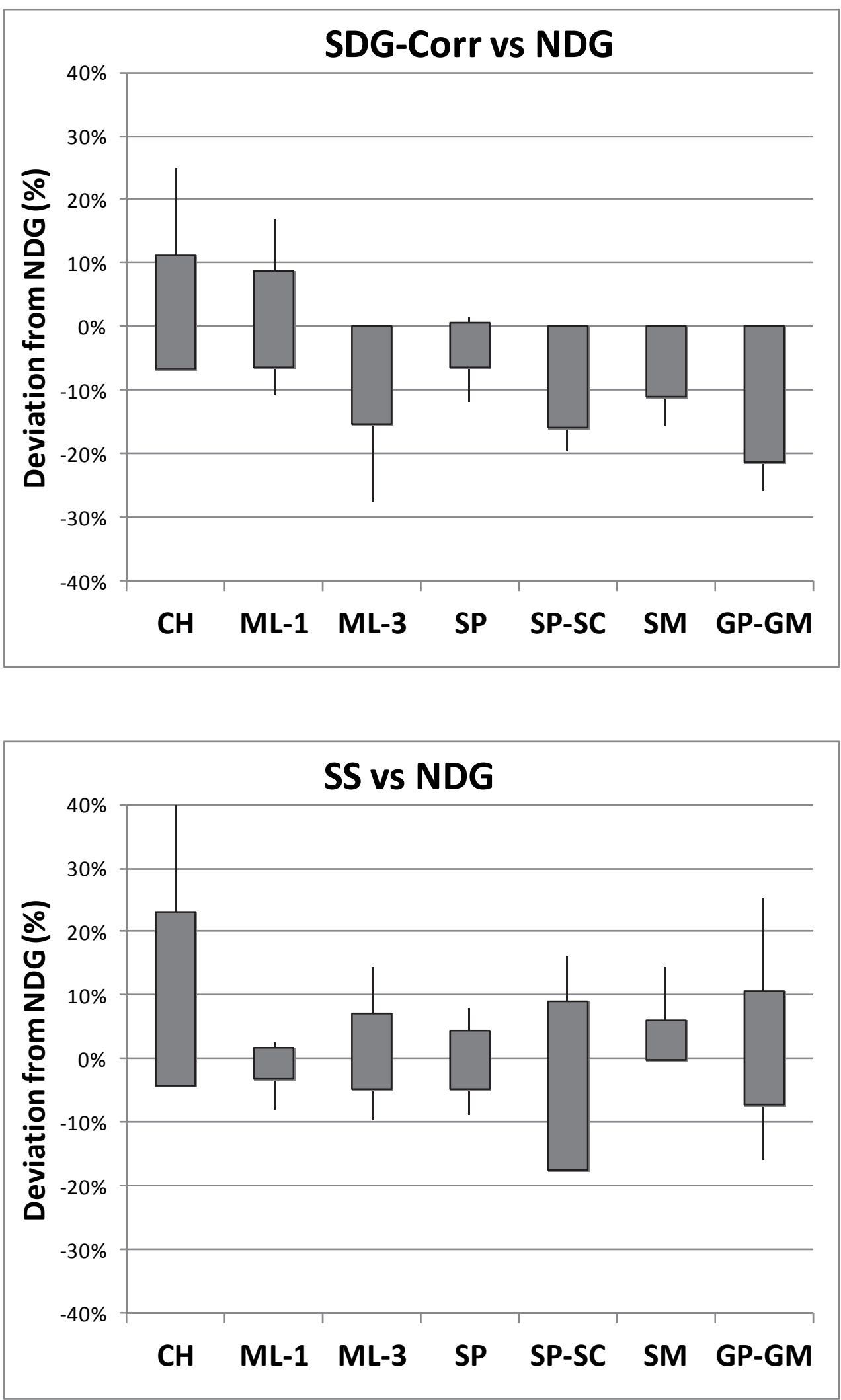


\section{Appendix D: Complete Field Data Collection}


ML-1 Soil - Test Item 1

\begin{tabular}{|c|c|c|c|c|c|c|c|c|c|}
\hline $\begin{array}{c}\text { Section } \\
1\end{array}$ & & Base & $\begin{array}{c}\text { Lift } 1 \\
\text { Pass } 8\end{array}$ & $\begin{array}{c}\text { Lift } 2 \\
\text { Pass } 8\end{array}$ & $\begin{array}{c}\text { Lift } 3 \\
\text { Pass } 1\end{array}$ & $\begin{array}{c}\text { Lift } 3 \\
\text { Pass } 2\end{array}$ & $\begin{array}{c}\text { Lift } 3 \\
\text { Pass } 4\end{array}$ & $\begin{array}{c}\text { Lift } 3 \\
\text { Pass } 8\end{array}$ & \begin{tabular}{|c|} 
Lift 3 \\
Pass $8 \mathrm{~W}$ \\
\end{tabular} \\
\hline \multirow{3}{*}{ NDG } & Calculated $\gamma_{\mathrm{d}}\left(\mathrm{lb} / \mathrm{ft}^{3}\right)$ & 97.69 & 100.38 & 98.32 & 90.48 & 93.39 & 97.62 & 100.16 & 97.08 \\
\hline & $\begin{array}{c}\text { Device moisture } \\
\text { content (wt\%) }\end{array}$ & 12.85 & 18.35 & 18.25 & 15.45 & 15.30 & 14.90 & 13.60 & 16.90 \\
\hline & \begin{tabular}{|c|}
$\begin{array}{c}\text { Lab moisture content } \\
\text { (wt } \%)\end{array}$ \\
\end{tabular} & 19.60 & 19.44 & 20.52 & 18.49 & 18.15 & 16.31 & 15.19 & 19.93 \\
\hline \multirow[b]{2}{*}{ DCP } & Blows/150mm & 16 & 5 & 5 & 4.00 & 5.00 & 5.00 & 7.00 & 10 \\
\hline & \begin{tabular}{|c|}
$\begin{array}{c}\text { Lab moisture content } \\
\text { (wt } \%)\end{array}$ \\
\end{tabular} & 19.60 & 19.44 & 20.52 & 18.49 & 18.15 & 16.31 & 15.19 & 19.93 \\
\hline \multirow{2}{*}{ SS } & Calculated $\gamma_{\mathrm{d}}\left(\mathrm{lb} / \mathrm{ft}^{3}\right)$ & & & & 88.11 & 94.28 & 97.55 & 97.43 & \\
\hline & \begin{tabular}{|c|}
$\begin{array}{c}\text { Lab moisture content } \\
\text { (wt } \%)\end{array}$ \\
\end{tabular} & & & & 17.27 & 17.44 & 16.55 & 16.73 & \\
\hline \multirow{2}{*}{ Clegg } & Impact Value & & & & 4.00 & 3.90 & 5.10 & 0.00 & 5.7 \\
\hline & \begin{tabular}{|c|}
$\begin{array}{c}\text { Lab moisture content } \\
\text { (wt } \%)\end{array}$ \\
\end{tabular} & & & & 18.77 & 16.43 & 16.43 & 0.00 & 19.75 \\
\hline \multirow[b]{2}{*}{ WB } & Calculated $\gamma_{\mathrm{d}}\left(\mathrm{lb} / \mathrm{ft}^{3}\right)$ & & & & 0.00 & 0.00 & 0.00 & 90.11 & \\
\hline & $\begin{array}{c}\begin{array}{c}\text { Lab moisture content } \\
\text { (wt } \%)\end{array} \\
\end{array}$ & & & & 18.52 & 16.85 & 16.65 & 16.64 & \\
\hline \multirow[b]{2}{*}{ SC } & Calculated $\gamma_{\mathrm{d}}\left(\mathrm{lb} / \mathrm{ft}^{3}\right)$ & & & & 92.50 & 99.80 & 92.92 & 95.75 & \\
\hline & \begin{tabular}{|c|}
$\begin{array}{c}\text { Lab moisture content } \\
\text { (wt } \%)\end{array}$ \\
\end{tabular} & & & & 14.35 & 16.85 & 15.64 & 16.33 & \\
\hline \multirow{3}{*}{ GG } & Modulus (ksi) -Avg & & & & 8.67 & 9.53 & 8.82 & 9.23 & 8.63 \\
\hline & $\begin{array}{c}\text { Stiffness (kip/in.) - } \\
\text { Avg }\end{array}$ & & & & 39.34 & 43.24 & 40.00 & 41.85 & 39.15 \\
\hline & \begin{tabular}{|c|}
$\begin{array}{c}\text { Lab moisture content } \\
\text { (wt } \%)\end{array}$ \\
\end{tabular} & & & & 17.27 & 17.50 & 12.95 & 14.98 & 18.97 \\
\hline \multirow{3}{*}{ SDG } & Calculated $\gamma_{\mathrm{d}}\left(\mathrm{lb} / \mathrm{ft}^{3}\right)$ & & 117.06 & 112.16 & 105.71 & 97.92 & 93.62 & 91.96 & 101.50 \\
\hline & $\begin{array}{c}\text { Device moisture } \\
\text { content (wt } \%)\end{array}$ & & 11.8 & 11.00 & 10.00 & 8.00 & 6.90 & 6.00 & 9.80 \\
\hline & \begin{tabular}{|c|}
$\begin{array}{c}\text { Lab moisture content } \\
\text { (wt } \%)\end{array}$ \\
\end{tabular} & & 19.16 & 18.19 & 17.99 & 16.31 & 15.43 & 13.98 & 18.80 \\
\hline \multirow{3}{*}{ MDI } & Calculated $\gamma_{\mathrm{d}}\left(\mathrm{lb} / \mathrm{ft}^{3}\right)$ & & & & 94.37 & 95.53 & 97.93 & 96.97 & 98.13 \\
\hline & $\begin{array}{c}\text { Device moisture } \\
\text { content (wt } \%)\end{array}$ & & & & 6.10 & 4.80 & 8.70 & 6.80 & 19.60 \\
\hline & \begin{tabular}{|c|}
$\begin{array}{c}\text { Lab moisture content } \\
(\mathrm{wt} \%)\end{array}$ \\
\end{tabular} & & & & 18.15 & 16.71 & 16.08 & 16.19 & 19.70 \\
\hline \multirow{3}{*}{ EDG } & Calculated $\gamma_{\mathrm{d}}\left(\mathrm{lb} / \mathrm{ft}^{3}\right)$ & & & & 103.71 & 96.31 & 92.59 & 119.58 & 118.18 \\
\hline & $\begin{array}{c}\text { Device moisture } \\
\text { content (wt \%) }\end{array}$ & & & & 13.40 & 14.70 & 17.00 & 13.10 & 15.00 \\
\hline & \begin{tabular}{|c|}
$\begin{array}{c}\text { Lab moisture content } \\
\text { (wt } \%)\end{array}$ \\
\end{tabular} & & & & 17.95 & 18.24 & 17.18 & 17.70 & 18.78 \\
\hline \multirow{3}{*}{ ZFW } & $\mathrm{s}(\mathrm{mm})$ & & & & 5.41 & 6.17 & 6.18 & 5.78 & 4.88 \\
\hline & $\mathrm{E}\left(\mathrm{MN} / \mathrm{m}^{2}\right)$ & & & & 5.50 & 4.90 & 4.90 & 5.20 & 6.20 \\
\hline & \begin{tabular}{|c|}
$\begin{array}{c}\text { Lab moisture content } \\
\text { (wt } \%)\end{array}$ \\
\end{tabular} & & & & 17.48 & 16.70 & 17.63 & 17.00 & 19.81 \\
\hline \multirow{3}{*}{ DFW } & Defl (um) -Avg & & & & & & & & \\
\hline & Emod (Mpa)- Avg & & & & & & & & \\
\hline & \begin{tabular}{|c|}
$\begin{array}{c}\text { Lab moisture content } \\
(\mathrm{wt} \%)\end{array}$ \\
\end{tabular} & & & & & & & & \\
\hline
\end{tabular}


ML-1 Soil - Test Item 1

\begin{tabular}{|c|c|c|c|c|c|c|c|c|c|}
\hline $\begin{array}{c}\text { Section } \\
2\end{array}$ & & Base & $\begin{array}{c}\text { Lift } 1 \\
\text { Pass } 8\end{array}$ & $\begin{array}{c}\text { Lift } 2 \\
\text { Pass } 8\end{array}$ & $\begin{array}{c}\text { Lift } 3 \\
\text { Pass } 1\end{array}$ & $\begin{array}{c}\text { Lift } 3 \\
\text { Pass } 2\end{array}$ & $\begin{array}{c}\text { Lift } 3 \\
\text { Pass } 4\end{array}$ & $\begin{array}{c}\text { Lift } 3 \\
\text { Pass } 8\end{array}$ & \begin{tabular}{|c|} 
Lift 3 \\
Pass $8 \mathrm{~W}$ \\
\end{tabular} \\
\hline \multirow{3}{*}{ NDG } & Calculated $\gamma_{\mathrm{d}}\left(\mathrm{lb} / \mathrm{ft}^{3}\right)$ & 110.97 & 100.95 & 101.96 & 92.37 & 96.10 & 97.38 & 100.11 & 94.97 \\
\hline & $\begin{array}{c}\text { Device moisture } \\
\text { content (wt } \%)\end{array}$ & 13.25 & 17.55 & 17.65 & 15.35 & 13.95 & 13.40 & 13.45 & 19.05 \\
\hline & \begin{tabular}{|c|}
$\begin{array}{c}\text { Lab moisture content } \\
\text { (wt } \%)\end{array}$ \\
\end{tabular} & 15.06 & 19.59 & 18.66 & 17.08 & 15.85 & 16.20 & 15.91 & 21.25 \\
\hline \multirow[b]{2}{*}{ DCP } & Blows/150mm & 23 & 3 & 4 & 3.00 & 4.00 & 5.00 & 6.00 & 9 \\
\hline & \begin{tabular}{|c|}
$\begin{array}{c}\text { Lab moisture content } \\
\text { (wt } \%)\end{array}$ \\
\end{tabular} & 15.06 & 19.59 & 18.66 & 17.08 & 15.85 & 16.20 & 15.91 & 21.25 \\
\hline \multirow{2}{*}{ SS } & Calculated $\gamma_{\mathrm{d}}\left(\mathrm{lb} / \mathrm{ft}^{3}\right)$ & & & & 88.23 & 97.99 & 93.43 & 94.27 & \\
\hline & \begin{tabular}{|c|}
$\begin{array}{c}\text { Lab moisture content } \\
\text { (wt } \%)\end{array}$ \\
\end{tabular} & & & & 16.69 & 17.52 & 16.21 & 16.28 & \\
\hline \multirow{2}{*}{ Clegg } & Impact Value & & & & 3.70 & 5.30 & 4.20 & 0.00 & 5.3 \\
\hline & \begin{tabular}{|c|}
$\begin{array}{c}\text { Lab moisture content } \\
\text { (wt } \%)\end{array}$ \\
\end{tabular} & & & & 16.66 & 15.95 & 15.03 & 0.00 & 21.75 \\
\hline \multirow[b]{2}{*}{ WB } & Calculated $\gamma_{\mathrm{d}}\left(\mathrm{lb} / \mathrm{ft}^{3}\right)$ & & & & 0.00 & 0.00 & 0.00 & 86.75 & \\
\hline & $\begin{array}{c}\begin{array}{c}\text { Lab moisture content } \\
\text { (wt } \%)\end{array} \\
\end{array}$ & & & & 17.67 & 13.66 & 16.89 & 16.48 & \\
\hline \multirow[b]{2}{*}{ SC } & Calculated $\gamma_{\mathrm{d}}\left(\mathrm{lb} / \mathrm{ft}^{3}\right)$ & & & & 93.38 & 102.87 & 96.26 & 96.80 & \\
\hline & \begin{tabular}{|c|}
$\begin{array}{c}\text { Lab moisture content } \\
\text { (wt } \%)\end{array}$ \\
\end{tabular} & & & & 13.84 & 13.66 & 14.47 & 15.72 & \\
\hline \multirow{3}{*}{ GG } & Modulus (ksi) -Avg & & & & 7.96 & 9.32 & 7.43 & 8.16 & 6.68 \\
\hline & $\begin{array}{c}\text { Stiffness (kip/in.) - } \\
\text { Avg }\end{array}$ & & & & 36.08 & 42.28 & 33.71 & 37.00 & 30.33 \\
\hline & \begin{tabular}{|c|}
$\begin{array}{c}\text { Lab moisture content } \\
\text { (wt } \%)\end{array}$ \\
\end{tabular} & & & & 17.71 & 16.30 & 14.55 & 16.11 & 22.41 \\
\hline \multirow{3}{*}{ SDG } & Calculated $\gamma_{\mathrm{d}}\left(\mathrm{lb} / \mathrm{ft}^{3}\right)$ & & 120.33 & 113.48 & 102.20 & 101.90 & 91.48 & 94.01 & 113.88 \\
\hline & $\begin{array}{c}\text { Device moisture } \\
\text { content (wt } \%)\end{array}$ & & 11.4 & 10.60 & 9.10 & 8.60 & 6.20 & 6.80 & 12.00 \\
\hline & \begin{tabular}{|c|}
$\begin{array}{c}\text { Lab moisture content } \\
\text { (wt } \%)\end{array}$ \\
\end{tabular} & & 19.62 & 18.71 & 17.25 & 16.34 & 15.30 & 14.85 & 21.30 \\
\hline \multirow{3}{*}{ MDI } & Calculated $\gamma_{\mathrm{d}}\left(\mathrm{lb} / \mathrm{ft}^{3}\right)$ & & & & 95.94 & 96.21 & 98.97 & 98.22 & 94.89 \\
\hline & $\begin{array}{c}\text { Device moisture } \\
\text { content (wt } \%)\end{array}$ & & & & 5.40 & 6.00 & 8.10 & 6.00 & 14.00 \\
\hline & \begin{tabular}{|c|}
$\begin{array}{c}\text { Lab moisture content } \\
(\mathrm{wt} \%)\end{array}$ \\
\end{tabular} & & & & 16.57 & 16.56 & 14.97 & 14.81 & 20.59 \\
\hline \multirow{3}{*}{ EDG } & Calculated $\gamma_{\mathrm{d}}\left(\mathrm{lb} / \mathrm{ft}^{3}\right)$ & & & & 113.70 & 108.40 & 87.51 & 109.66 & 117.27 \\
\hline & $\begin{array}{c}\text { Device moisture } \\
\text { content (wt } \% \text { ) }\end{array}$ & & & & 11.20 & 15.10 & 18.30 & 12.20 & 14.80 \\
\hline & \begin{tabular}{|c|}
$\begin{array}{c}\text { Lab moisture content } \\
\text { (wt } \%)\end{array}$ \\
\end{tabular} & & & & 17.25 & 15.77 & 16.82 & 16.80 & 19.73 \\
\hline \multirow{3}{*}{ ZFW } & $\mathrm{s}(\mathrm{mm})$ & & & & 7.43 & 6.86 & 5.88 & 6.26 & 6.21 \\
\hline & $\mathrm{E}\left(\mathrm{MN} / \mathrm{m}^{2}\right)$ & & & & 4.00 & 4.40 & 5.10 & 4.80 & 4.80 \\
\hline & \begin{tabular}{|c|}
$\begin{array}{c}\text { Lab moisture content } \\
\text { (wt } \%)\end{array}$ \\
\end{tabular} & & & & 17.62 & 18.21 & 17.56 & 16.99 & 20.96 \\
\hline \multirow{3}{*}{ DFW } & Defl (um) -Avg & & & & & & & & \\
\hline & Emod (Mpa)- Avg & & & & & & & & \\
\hline & \begin{tabular}{|c|}
$\begin{array}{c}\text { Lab moisture content } \\
(\mathrm{wt} \%)\end{array}$ \\
\end{tabular} & & & & & & & & \\
\hline
\end{tabular}


ML-1 Soil - Test Item 1

\begin{tabular}{|c|c|c|c|c|c|c|c|c|c|}
\hline $\begin{array}{c}\text { Section } \\
3 \\
\end{array}$ & & Base & $\begin{array}{c}\text { Lift } 1 \\
\text { Pass } 8 \\
\end{array}$ & $\begin{array}{c}\text { Lift } 2 \\
\text { Pass } 8 \\
\end{array}$ & $\begin{array}{c}\text { Lift } 3 \\
\text { Pass } 1 \\
\end{array}$ & $\begin{array}{c}\text { Lift } 3 \\
\text { Pass } 2 \\
\end{array}$ & $\begin{array}{c}\text { Lift } 3 \\
\text { Pass } 4 \\
\end{array}$ & $\begin{array}{c}\text { Lift } 3 \\
\text { Pass } 8 \\
\end{array}$ & \begin{tabular}{|c|} 
Lift 3 \\
Pass $8 \mathrm{~W}$ \\
\end{tabular} \\
\hline \multirow{3}{*}{ NDG } & Calculated $\gamma_{\mathrm{d}}\left(\mathrm{lb} / \mathrm{ft}^{3}\right)$ & 107.82 & 99.72 & 100.71 & 90.54 & 93.71 & 96.19 & 98.44 & 95.80 \\
\hline & $\begin{array}{c}\text { Device moisture } \\
\text { content (wt\%) }\end{array}$ & 15.00 & 19.05 & 17.95 & 14.30 & 14.40 & 13.00 & 13.45 & 17.75 \\
\hline & \begin{tabular}{|c|}
$\begin{array}{c}\text { Lab moisture content } \\
(\mathrm{wt} \%)\end{array}$ \\
\end{tabular} & 17.00 & 19.68 & 18.98 & 17.05 & 16.33 & 16.25 & 14.81 & 19.60 \\
\hline \multirow[b]{2}{*}{ DCP } & "Blows/150mm & 26 & 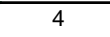 & 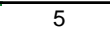 & 3.00 & 4.00 & 5.00 & 6.00 & 96 \\
\hline & \begin{tabular}{|c|}
$\begin{array}{c}\text { Lab moisture content } \\
(\mathrm{wt} \%)\end{array}$ \\
\end{tabular} & 17.00 & 19.68 & 18.98 & 17.05 & 16.33 & 16.25 & 14.81 & 19.60 \\
\hline \multirow{2}{*}{ SS } & Calculated $\gamma_{\mathrm{d}}\left(\mathrm{lb} / \mathrm{ft}^{3}\right)$ & & & & 83.35 & 96.02 & 95.89 & 96.54 & \\
\hline & \begin{tabular}{|c|}
$\begin{array}{c}\text { Lab moisture content } \\
(\mathrm{wt} \%)\end{array}$ \\
\end{tabular} & & & & 16.82 & 16.21 & 15.81 & 16.78 & \\
\hline \multirow{2}{*}{ Clegg } & Impact Value & & & & 3.20 & 3.90 & 4.20 & 0.00 & 4.9 \\
\hline & \begin{tabular}{|c|}
$\begin{array}{c}\text { Lab moisture content } \\
(\mathrm{wt} \%)\end{array}$ \\
\end{tabular} & & & & 15.94 & 16.76 & 15.35 & 0.00 & 21.05 \\
\hline \multirow[b]{2}{*}{ WB } & Calculated $\gamma_{\mathrm{d}}\left(\mathrm{lb} / \mathrm{ft}^{3}\right)$ & & & & 0.00 & 0.00 & 0.00 & 87.96 & \\
\hline & \begin{tabular}{|c|}
$\begin{array}{c}\text { Lab moisture content } \\
(\mathrm{wt} \%)\end{array}$ \\
\end{tabular} & & & & 17.87 & 12.68 & 16.72 & 16.20 & \\
\hline \multirow[b]{2}{*}{ SC } & Calculated $\gamma_{\mathrm{d}}\left(\mathrm{lb} / \mathrm{ft}^{3}\right)$ & & & & 89.94 & 100.88 & 98.90 & 95.87 & \\
\hline & \begin{tabular}{|c|}
$\begin{array}{c}\text { Lab moisture content } \\
(\mathrm{wt} \%)\end{array}$ \\
\end{tabular} & & & & 16.19 & 12.68 & 14.95 & 15.31 & \\
\hline \multirow{3}{*}{ GG } & Modulus (ksi) - Avg & & & & 7.95 & 8.59 & 8.64 & 8.21 & 7.44 \\
\hline & $\begin{array}{c}\text { Stiffness (kip/in.) - } \\
\text { Avg }\end{array}$ & & & & 36.05 & 38.97 & 39.20 & 37.21 & 33.76 \\
\hline & \begin{tabular}{|c|}
$\begin{array}{c}\text { Lab moisture content } \\
(\mathrm{wt} \%)\end{array}$ \\
\end{tabular} & & & & 17.16 & 16.00 & 15.12 & 15.54 & 21.49 \\
\hline \multirow{3}{*}{ SDG } & Calculated $\gamma_{\mathrm{d}}\left(\mathrm{lb} / \mathrm{ft}^{3}\right)$ & & 120.31 & 103.30 & 103.01 & 98.56 & 92.35 & 94.98 & 103.65 \\
\hline & $\begin{array}{l}\text { Device moisture } \\
\text { content (wt\%) }\end{array}$ & & 12.2 & 10.00 & 9.40 & 7.80 & 6.00 & 6.70 & 10.40 \\
\hline & \begin{tabular}{|c|}
$\begin{array}{c}\text { Lab moisture content } \\
(\mathrm{wt} \%)\end{array}$ \\
\end{tabular} & & 20.06 & 18.34 & 17.26 & 16.97 & 13.29 & 14.66 & 20.02 \\
\hline \multirow{3}{*}{ MDI } & Calculated $\gamma_{\mathrm{d}}\left(\mathrm{lb} / \mathrm{ft}^{3}\right)$ & & & & 95.62 & 97.47 & 97.25 & 97.20 & 94.56 \\
\hline & $\begin{array}{c}\text { Device moisture } \\
\text { content (wt\%) }\end{array}$ & & & & 5.90 & 5.10 & 7.80 & 6.60 & 17.60 \\
\hline & \begin{tabular}{|c|}
$\begin{array}{c}\text { Lab moisture content } \\
(\mathrm{wt} \%)\end{array}$ \\
\end{tabular} & & & & 17.07 & 15.10 & 16.31 & 15.92 & 21.98 \\
\hline \multirow{3}{*}{ EDG } & Calculated $\gamma_{\mathrm{d}}\left(\mathrm{lb} / \mathrm{ft}^{3}\right)$ & & & & 115.09 & 74.05 & 75.93 & 121.68 & 119.38 \\
\hline & $\begin{array}{c}\text { Device moisture } \\
\text { content (wt\%) }\end{array}$ & & & & 12.00 & 19.70 & 19.80 & 13.20 & 14.20 \\
\hline & \begin{tabular}{|c|}
$\begin{array}{c}\text { Lab moisture content } \\
\text { (wt } \%)\end{array}$ \\
\end{tabular} & & & & 17.79 & 17.08 & 17.74 & 16.37 & 18.79 \\
\hline \multirow{3}{*}{ ZFW } & $\mathrm{s}(\mathrm{mm})$ & & & & 8.05 & 7.98 & 6.13 & 7.23 & 4.77 \\
\hline & $\mathrm{E}\left(\mathrm{MN} / \mathrm{m}^{2}\right)$ & & & & 3.70 & 3.80 & 4.90 & 4.20 & 6.30 \\
\hline & \begin{tabular}{|c|}
$\begin{array}{c}\text { Lab moisture content } \\
(\mathrm{wt} \%)\end{array}$ \\
\end{tabular} & & & & 16.98 & 16.30 & 16.80 & 16.57 & 19.34 \\
\hline \multirow{3}{*}{ DFW } & Defl (um) -Avg & & & & & & & & \\
\hline & Emod (Mpa)- Avg & & & & & & & & \\
\hline & \begin{tabular}{|c|}
$\begin{array}{c}\text { Lab moisture content } \\
(\mathrm{wt} \%)\end{array}$ \\
\end{tabular} & & & & & & & & \\
\hline
\end{tabular}


ML-1 Soil - Test Item 1

\begin{tabular}{|c|c|c|c|c|c|c|c|c|c|}
\hline $\begin{array}{c}\text { Section } \\
4 \\
\end{array}$ & & Base & $\begin{array}{c}\text { Lift } 1 \\
\text { Pass } 8 \\
\end{array}$ & $\begin{array}{c}\text { Lift } 2 \\
\text { Pass } 8 \\
\end{array}$ & $\begin{array}{c}\text { Lift } 3 \\
\text { Pass } 1 \\
\end{array}$ & $\begin{array}{c}\text { Lift } 3 \\
\text { Pass } 2 \\
\end{array}$ & $\begin{array}{c}\text { Lift } 3 \\
\text { Pass } 4 \\
\end{array}$ & $\begin{array}{c}\text { Lift } 3 \\
\text { Pass } 8 \\
\end{array}$ & $\begin{array}{c}\text { Lift } 3 \\
\text { Pass 8W } \\
\end{array}$ \\
\hline \multirow{3}{*}{ NDG } & Calculated $\gamma_{\mathrm{d}}\left(\mathrm{lb} / \mathrm{ft}^{3}\right)$ & 99.79 & 96.64 & 100.81 & 90.97 & 96.23 & 97.40 & 100.10 & 94.27 \\
\hline & $\begin{array}{c}\text { Device moisture } \\
\text { content (wt\%) }\end{array}$ & 14.80 & 19.15 & 18.30 & 14.80 & 14.20 & 13.15 & 13.65 & 18.15 \\
\hline & $\begin{array}{c}\text { Lab moisture content } \\
(\mathrm{wt} \%)\end{array}$ & 18.34 & 21.11 & 18.37 & 17.04 & 15.33 & 16.29 & 15.99 & 21.15 \\
\hline \multirow[b]{2}{*}{ DCP } & Blows/150mm & 22 & 3 & 5 & 3.00 & 7.00 & 6.00 & 6.00 & 9 \\
\hline & \begin{tabular}{|c|}
$\begin{array}{c}\text { Lab moisture content } \\
(\mathrm{wt} \%)\end{array}$ \\
\end{tabular} & 18.34 & 21.11 & 18.37 & 17.04 & 15.33 & 16.29 & 15.99 & 21.15 \\
\hline \multirow[b]{2}{*}{ SS } & Calculated $\gamma_{\mathrm{d}}\left(\mathrm{lb} / \mathrm{ft}^{3}\right)$ & & & & 85.40 & 93.98 & 96.28 & 99.34 & \\
\hline & $\begin{array}{c}\begin{array}{c}\text { Lab moisture content } \\
(\mathrm{wt} \%)\end{array} \\
\end{array}$ & & & & 17.65 & 16.54 & 16.64 & 15.24 & \\
\hline \multirow[b]{2}{*}{ Clegg } & Impact Value & & & & 3.20 & 4.40 & 4.90 & 0.00 & 5.5 \\
\hline & \begin{tabular}{|c|} 
Lab moisture content \\
$(\mathrm{wt} \%)$
\end{tabular} & & & & 17.68 & 16.00 & 14.42 & 0.00 & 20.8 \\
\hline \multirow[b]{2}{*}{ WB } & Calculated $\gamma_{\mathrm{d}}\left(\mathrm{lb} / \mathrm{ft}^{3}\right)$ & & & & 0.00 & 0.00 & 0.00 & 130.42 & \\
\hline & \begin{tabular}{|c|}
$\begin{array}{c}\text { Lab moisture content } \\
(\mathrm{wt} \%)\end{array}$ \\
\end{tabular} & & & & 16.87 & 12.12 & 16.21 & 16.60 & \\
\hline \multirow[b]{2}{*}{ SC } & Calculated $\gamma_{\mathrm{d}}\left(\mathrm{lb} / \mathrm{ft}^{3}\right)$ & & & & 96.83 & 101.58 & 99.93 & 97.09 & \\
\hline & $\begin{array}{c}\begin{array}{c}\text { Lab moisture content } \\
(\mathrm{wt} \%)\end{array} \\
\end{array}$ & & & & 13.99 & 12.12 & 15.58 & 15.84 & \\
\hline \multirow{3}{*}{ GG } & Modulus (ksi) -Avg & & & & 7.91 & 8.21 & 7.40 & 7.31 & 8.12 \\
\hline & $\begin{array}{c}\text { Stiffness (kip/in.) - } \\
\text { Avg }\end{array}$ & & & & 35.85 & 37.23 & 33.25 & 33.22 & 36.82 \\
\hline & \begin{tabular}{|c|}
$\begin{array}{c}\text { Lab moisture content } \\
(\mathrm{wt} \%)\end{array}$ \\
\end{tabular} & & & & 16.63 & 15.51 & 15.04 & 15.64 & 19.41 \\
\hline \multirow{3}{*}{ SDG } & Calculated $\gamma_{\mathrm{d}}\left(\mathrm{lb} / \mathrm{ft}^{3}\right)$ & & 112.38 & 103.11 & 99.02 & 100.51 & 86.88 & 91.93 & 109.40 \\
\hline & $\begin{array}{c}\text { Device moisture } \\
\text { content (wt\%) }\end{array}$ & & 11.4 & 9.60 & 8.20 & 8.20 & 5.20 & 5.70 & 11.60 \\
\hline & \begin{tabular}{|c|}
$\begin{array}{c}\text { Lab moisture content } \\
\text { (wt } \%)\end{array}$ \\
\end{tabular} & & 20.13 & 17.64 & 17.89 & 16.8 & 16.22 & 13.36 & 22.08 \\
\hline \multirow{3}{*}{ MDI } & Calculated $\gamma_{\mathrm{d}}\left(\mathrm{lb} / \mathrm{ft}^{3}\right)$ & & & & 96.25 & 98.55 & 98.21 & 96.73 & 95.00 \\
\hline & $\begin{array}{c}\text { Device moisture } \\
\text { content (wt } \%)\end{array}$ & & & & 4.80 & 6.20 & 8.00 & 7.20 & 15.60 \\
\hline & \begin{tabular}{|c|}
$\begin{array}{c}\text { Lab moisture content } \\
\text { (wt } \%)\end{array}$ \\
\end{tabular} & & & & 16.01 & 14.60 & 15.63 & 16.54 & 21.03 \\
\hline \multirow{3}{*}{ EDG } & Calculated $\gamma_{\mathrm{d}}\left(\mathrm{lb} / \mathrm{ft}^{3}\right)$ & & & & 120.35 & 100.74 & 66.38 & 113.79 & 120.36 \\
\hline & $\begin{array}{c}\text { Device moisture } \\
\text { content (wt\%) }\end{array}$ & & & & 11.60 & 16.80 & 23.60 & 12.50 & 15.90 \\
\hline & \begin{tabular}{|c|}
$\begin{array}{c}\text { Lab moisture content } \\
(\mathrm{wt} \%)\end{array}$ \\
\end{tabular} & & & & 17.85 & 16.61 & 17.23 & 16.02 & 22.45 \\
\hline \multirow{3}{*}{ ZFW } & $\mathrm{s}(\mathrm{mm})$ & & & & 6.07 & 5.79 & 4.81 & 5.42 & 6.45 \\
\hline & $\mathrm{E}\left(\mathrm{MN} / \mathrm{m}^{2}\right)$ & & & & 4.90 & 5.20 & 6.20 & 5.50 & 4.70 \\
\hline & \begin{tabular}{|c|}
$\begin{array}{c}\text { Lab moisture content } \\
(\mathrm{wt} \%)\end{array}$ \\
\end{tabular} & & & & 16.16 & 16.05 & 16.17 & 16.74 & 21.60 \\
\hline \multirow{3}{*}{ DFW } & Defl (um) -Avg & & & & & & & & \\
\hline & Emod (Mpa)- Avg & & & & & & & & \\
\hline & \begin{tabular}{|c|}
$\begin{array}{c}\text { Lab moisture content } \\
(\mathrm{wt} \%)\end{array}$ \\
\end{tabular} & & & & & & & & \\
\hline
\end{tabular}


SP Soil - Test Item 2

\begin{tabular}{|c|c|c|c|c|c|c|c|c|c|}
\hline $\begin{array}{c}\text { Section } \\
1 \\
\end{array}$ & & Base & $\begin{array}{l}\text { Lift 1- } \\
\text { Pass } 8 \\
\end{array}$ & $\begin{array}{c}\text { Lift } 2 \\
\text { Pass } 8 \\
\end{array}$ & $\begin{array}{c}\text { Lift } 3 \\
\text { Pass } 1 \\
\end{array}$ & $\begin{array}{c}\text { Lift } 3 \\
\text { Pass } 2 \\
\end{array}$ & $\begin{array}{c}\text { Lift } 3 \\
\text { Pass } 4 \\
\end{array}$ & $\begin{array}{c}\text { Lift } 3 \\
\text { Pass } 8 \\
\end{array}$ & \begin{tabular}{|c|} 
Lift 3 \\
Pass 8W \\
\end{tabular} \\
\hline \multirow{3}{*}{ NDG } & Calculated $\gamma_{\mathrm{d}}\left(\mathrm{lb} / \mathrm{ft}^{3}\right)$ & 108.95 & 104.40 & 103.94 & 104.60 & 105.79 & 104.08 & 104.47 & 105.13 \\
\hline & $\begin{array}{c}\text { Device moisture } \\
\text { content (wt\%) }\end{array}$ & 13.50 & 4.05 & 4.05 & 3.80 & 3.80 & 3.55 & 3.60 & 5.05 \\
\hline & \begin{tabular}{|c|}
$\begin{array}{c}\text { Lab moisture content } \\
\text { (wt\%) }\end{array}$ \\
\end{tabular} & 14.08 & 5.13 & 5.38 & 4.26 & 3.78 & 5.25 & 4.68 & 5.50 \\
\hline \multirow[b]{2}{*}{ DCP } & Blows/150mm & 0 & 2 & 3 & 2.00 & 3.00 & 4.00 & 3.00 & $\overline{5}$ \\
\hline & \begin{tabular}{|c|} 
Lab moisture content \\
(wt $\%)$
\end{tabular} & 14.08 & 5.13 & 5.38 & 4.26 & 3.78 & 5.25 & 4.68 & 5.50 \\
\hline \multirow{2}{*}{ ss } & Calculated $\gamma_{\mathrm{d}}\left(\mathrm{lb} / \mathrm{ft}^{3}\right)$ & & & & 105.45 & 96.38 & 104.29 & 96.99 & \\
\hline & \begin{tabular}{|c|}
$\begin{array}{c}\text { Lab moisture content } \\
\text { (wt\%) }\end{array}$ \\
\end{tabular} & & & & 4.22 & 4.00 & 4.76 & 5.19 & \\
\hline \multirow{2}{*}{ Clegg } & Impact Value & & & & 2.80 & 2.00 & 2.40 & 2.10 & 2.1 \\
\hline & \begin{tabular}{|c|}
$\begin{array}{c}\text { Lab moisture content } \\
\text { (wt } \%)\end{array}$ \\
\end{tabular} & & & & 4.04 & 4.16 & 4.02 & 4.60 & 4.6 \\
\hline \multirow[b]{2}{*}{ WB } & Calculated $\gamma_{\mathrm{d}}\left(\mathrm{lb} / \mathrm{ft}^{3}\right)$ & & & & & & & & \\
\hline & \begin{tabular}{|c|}
$\begin{array}{c}\text { Lab moisture content } \\
\text { (wt } \%)\end{array}$ \\
\end{tabular} & & & & & & & & \\
\hline \multirow[b]{2}{*}{ SC } & Calculated $\gamma_{\mathrm{d}}\left(\mathrm{lb} / \mathrm{ft}^{3}\right)$ & & & & 107.37 & 108.03 & 104.41 & 106.67 & \\
\hline & \begin{tabular}{|c|}
$\begin{array}{c}\text { Lab moisture content } \\
\text { (wt } \%)\end{array}$ \\
\end{tabular} & & & & 4.90 & 3.63 & 4.47 & 3.90 & \\
\hline \multirow{3}{*}{ GG } & Modulus (ksi) -Avg & & & & 4.26 & 4.30 & 4.46 & 4.16 & 3.42 \\
\hline & $\begin{array}{c}\text { Stiffness (kip/in.) - } \\
\text { Avg }\end{array}$ & & & & 19.34 & 19.50 & 20.21 & 18.88 & 15.51 \\
\hline & \begin{tabular}{|c|}
$\begin{array}{c}\text { Lab moisture content } \\
\text { (wt } \%)\end{array}$ \\
\end{tabular} & & & & 4.59 & 4.59 & 4.85 & 3.80 & 5.04 \\
\hline \multirow{3}{*}{ SDG } & Calculated $\gamma_{\mathrm{d}}\left(\mathrm{lb} / \mathrm{ft}^{3}\right)$ & & 99.71 & 106.49 & 92.37 & 98.36 & 93.46 & 92.92 & 105.83 \\
\hline & $\begin{array}{l}\text { Device moisture } \\
\text { content (wt \%) }\end{array}$ & & 2.1 & 3.40 & 0.20 & 1.50 & 0.10 & 1.10 & 3.20 \\
\hline & \begin{tabular}{|c|}
$\begin{array}{c}\text { Lab moisture content } \\
\text { (wt\%) }\end{array}$ \\
\end{tabular} & & 5.49 & 4.75 & 3.58 & 4.87 & 3.85 & 8.63 & 4.57 \\
\hline \multirow{3}{*}{ MDI } & Calculated $\gamma_{\mathrm{d}}\left(\mathrm{lb} / \mathrm{ft}^{3}\right)$ & & & & 106.95 & 106.66 & 107.10 & 106.14 & 106.89 \\
\hline & $\begin{array}{l}\text { Device moisture } \\
\text { content (wt\%) }\end{array}$ & & & & 0.10 & 0.10 & 0.10 & 0.60 & 1.00 \\
\hline & \begin{tabular}{|c|} 
Lab moisture content \\
(wt $\%)$
\end{tabular} & & & & 4.34 & 4.34 & 3.95 & 5.15 & 4.90 \\
\hline \multirow{3}{*}{ EDG } & Calculated $\gamma_{\mathrm{d}}\left(\mathrm{lb} / \mathrm{ft}^{3}\right)$ & & & & 105.44 & 104.62 & 102.39 & 97.56 & 105.10 \\
\hline & $\begin{array}{c}\text { Device moisture } \\
\text { content (wt } \%)\end{array}$ & & & & 4.30 & 4.40 & 4.40 & 1.30 & 10.40 \\
\hline & \begin{tabular}{|c|} 
Lab moisture content \\
(wt $\%)$
\end{tabular} & & & & 3.62 & 4.11 & 3.95 & 4.54 & 5.74 \\
\hline \multirow{3}{*}{ ZFW } & $\mathrm{s}(\mathrm{mm})$ & & & & 2.45 & 2.84 & 4.16 & 4.37 & 1.90 \\
\hline & $\mathrm{E}\left(\mathrm{MN} / \mathrm{m}^{2}\right)$ & & & & 12.20 & 10.60 & 7.20 & 6.90 & 15.80 \\
\hline & \begin{tabular}{|c|} 
Lab moisture content \\
(wt $\%)$
\end{tabular} & & & & 4.33 & 4.61 & 4.24 & 12.15 & 5.10 \\
\hline \multirow{3}{*}{ DFW } & Defl (um) -Avg & & & & 2089.33 & 2114.00 & 2035.33 & 1537.33 & 2073.00 \\
\hline & Emod (Mpa)- Avg & & & & 11.67 & 11.67 & 13.00 & 17.67 & 11.67 \\
\hline & \begin{tabular}{|c|} 
Lab moisture content \\
(wt $\%)$
\end{tabular} & & & & 4.93 & 4.91 & 5.13 & 12.80 & 4.74 \\
\hline
\end{tabular}


SP Soil - Test Item 2

\begin{tabular}{|c|c|c|c|c|c|c|c|c|c|}
\hline $\begin{array}{c}\text { Section } \\
2 \\
\end{array}$ & & Base & $\begin{array}{l}\text { Lift 1- } \\
\text { Pass } 8 \\
\end{array}$ & $\begin{array}{c}\text { Lift } 2 \\
\text { Pass } 8 \\
\end{array}$ & $\begin{array}{c}\text { Lift } 3 \\
\text { Pass } 1 \\
\end{array}$ & $\begin{array}{c}\text { Lift } 3 \\
\text { Pass } 2 \\
\end{array}$ & $\begin{array}{c}\text { Lift } 3 \\
\text { Pass } 4 \\
\end{array}$ & $\begin{array}{c}\text { Lift } 3 \\
\text { Pass } 8 \\
\end{array}$ & \begin{tabular}{|c|} 
Lift 3 \\
Pass 8W \\
\end{tabular} \\
\hline \multirow{3}{*}{ NDG } & Calculated $\gamma_{\mathrm{d}}\left(\mathrm{lb} / \mathrm{ft}^{3}\right)$ & 105.19 & 105.77 & 104.31 & 103.54 & 104.67 & 103.06 & 103.58 & 103.24 \\
\hline & $\begin{array}{l}\text { Device moisture } \\
\text { content (wt\%) }\end{array}$ & 13.00 & 3.40 & 3.40 & 3.40 & 3.55 & 3.95 & 3.45 & 4.95 \\
\hline & \begin{tabular}{|c|} 
Lab moisture content \\
(wt $\%)$
\end{tabular} & 17.53 & 4.54 & 5.86 & 4.83 & 4.32 & 4.71 & 4.84 & 4.72 \\
\hline \multirow[b]{2}{*}{ DCP } & Blows $/ 150 \mathrm{~mm}$ & 0 & 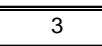 & 3 & 3.00 & 3.00 & 3.00 & 3.00 & 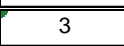 \\
\hline & \begin{tabular}{|c|}
$\begin{array}{c}\text { Lab moisture content } \\
\text { (wt\%) }\end{array}$ \\
\end{tabular} & 17.53 & 4.54 & 5.86 & 4.83 & 4.32 & 4.71 & 4.84 & 4.72 \\
\hline \multirow{2}{*}{ ss } & Calculated $\gamma_{\mathrm{d}}\left(\mathrm{lb} / \mathrm{ft}^{3}\right)$ & & & & 105.04 & 104.32 & 104.66 & 110.55 & \\
\hline & \begin{tabular}{|c|} 
Lab moisture content \\
$(\mathrm{w} \%)$
\end{tabular} & & & & 5.20 & 4.82 & 3.89 & 4.37 & \\
\hline \multirow{2}{*}{ Clegg } & Impact Value & & & & 2.60 & 2.00 & 1.70 & 2.80 & 2.8 \\
\hline & \begin{tabular}{|c|}
$\begin{array}{c}\text { Lab moisture content } \\
(\mathrm{w} \%)\end{array}$ \\
\end{tabular} & & & & 4.52 & 4.31 & 4.79 & 4.43 & 4.43 \\
\hline \multirow[b]{2}{*}{ WB } & Calculated $\gamma_{\mathrm{d}}\left(\mathrm{lb} / \mathrm{ft}^{3}\right)$ & & & & & & & & \\
\hline & \begin{tabular}{|c|}
$\begin{array}{c}\text { Lab moisture content } \\
(\mathrm{wt} \%)\end{array}$ \\
\end{tabular} & & & & & 4.52 & & & \\
\hline \multirow[b]{2}{*}{ SC } & Calculated $\gamma_{\mathrm{d}}\left(\mathrm{lb} / \mathrm{ft}^{3}\right)$ & & & & 106.01 & 107.13 & 103.88 & 108.78 & \\
\hline & \begin{tabular}{|c|} 
Lab moisture content \\
$(\mathrm{wt} \%)$
\end{tabular} & & & & 4.92 & 4.52 & 4.35 & 4.58 & \\
\hline \multirow{3}{*}{ GG } & Modulus (ksi) -Avg & & & & 4.17 & 4.15 & 3.80 & 4.10 & 3.25 \\
\hline & $\begin{array}{c}\text { Stiffness (kip/in.) - } \\
\text { Avg }\end{array}$ & & & & 18.88 & 18.84 & 17.25 & 18.63 & 14.74 \\
\hline & \begin{tabular}{|c|}
$\begin{array}{c}\text { Lab moisture content } \\
(\mathrm{wt} \%)\end{array}$ \\
\end{tabular} & & & & 4.78 & 4.20 & 5.06 & 4.80 & 5.26 \\
\hline \multirow{3}{*}{ SDG } & Calculated $\gamma_{\mathrm{d}}\left(\mathrm{b} / \mathrm{ft}^{3}\right)$ & & 100.37 & 102.87 & 101.52 & 100.31 & 97.18 & 93.58 & 102.08 \\
\hline & $\begin{array}{l}\text { Device moisture } \\
\text { content (wt \%) }\end{array}$ & & 2.1 & 2.80 & 2.40 & 1.90 & 1.10 & -0.10 & 2.60 \\
\hline & \begin{tabular}{|c|}
$\begin{array}{c}\text { Lab moisture content } \\
\text { (wt\%) }\end{array}$ \\
\end{tabular} & & 5.22 & 5.28 & 4.68 & 4.56 & 4.44 & 3.53 & 5.04 \\
\hline \multirow{3}{*}{ MDI } & Calculated $\gamma_{\mathrm{d}}\left(\mathrm{lb} / \mathrm{ft}^{3}\right)$ & & & & 106.74 & 105.70 & 105.89 & 106.19 & 107.21 \\
\hline & $\begin{array}{c}\text { Device moisture } \\
\text { content (wt\%) }\end{array}$ & & & & 0.60 & 0.40 & 0.40 & 0.10 & 0.70 \\
\hline & \begin{tabular}{|c|}
$\begin{array}{c}\text { Lab moisture content } \\
(\mathrm{wt} \%)\end{array}$ \\
\end{tabular} & & & & 4.61 & 5.20 & 5.20 & 4.76 & 4.36 \\
\hline \multirow{3}{*}{ EDG } & Calculated $\gamma_{\mathrm{d}}\left(\mathrm{b} / \mathrm{ft}^{3}\right)$ & & & & 106.02 & 104.32 & 101.29 & 100.14 & 104.81 \\
\hline & $\begin{array}{c}\text { Device moisture } \\
\text { content (wt } \%)\end{array}$ & & & & 9.10 & 5.10 & 3.60 & 5.30 & 8.90 \\
\hline & \begin{tabular}{|c|}
$\begin{array}{c}\text { Lab moisture content } \\
(\mathrm{wt} \%)\end{array}$ \\
\end{tabular} & & & & 5.17 & 4.90 & 4.89 & 4.81 & 5.75 \\
\hline \multirow{3}{*}{ ZFW } & $\mathrm{s}(\mathrm{mm})$ & & & & 2.22 & 2.43 & 4.61 & 1.85 & 1.68 \\
\hline & $\mathrm{E}\left(\mathrm{MN} / \mathrm{m}^{2}\right)$ & & & & 13.50 & 12.40 & 6.50 & 16.20 & 17.80 \\
\hline & \begin{tabular}{|c|}
$\begin{array}{c}\text { Lab moisture content } \\
(\mathrm{wt} \%)\end{array}$ \\
\end{tabular} & & & & 5.64 & 4.91 & 5.18 & 11.58 & 5.11 \\
\hline \multirow{3}{*}{ DFW } & Defl (um) -Avg & & & & 1947.67 & 1877.33 & 2095.33 & 2216.67 & 2218.33 \\
\hline & Emod (Mpa)- Avg & & & & 12.67 & 13.67 & 13.00 & 7.33 & 11.67 \\
\hline & $\begin{array}{c}\text { Lab moisture content } \\
(\mathrm{wt} \%)\end{array}$ & & & & 4.46 & 5.57 & 4.46 & 11.66 & 5.58 \\
\hline
\end{tabular}


SP Soil - Test Item 2

\begin{tabular}{|c|c|c|c|c|c|c|c|c|c|}
\hline $\begin{array}{c}\text { Section } \\
3 \\
\end{array}$ & & Base & $\begin{array}{l}\text { Lift 1- } \\
\text { Pass } 8 \\
\end{array}$ & $\begin{array}{c}\text { Lift } 2 \\
\text { Pass } 8 \\
\end{array}$ & $\begin{array}{c}\text { Lift } 3 \\
\text { Pass } 1 \\
\end{array}$ & $\begin{array}{c}\text { Lift } 3 \\
\text { Pass } 2 \\
\end{array}$ & $\begin{array}{c}\text { Lift } 3 \\
\text { Pass } 4 \\
\end{array}$ & $\begin{array}{c}\text { Lift } 3 \\
\text { Pass } 8 \\
\end{array}$ & \begin{tabular}{|c|} 
Lift 3 \\
Pass 8W \\
\end{tabular} \\
\hline \multirow{3}{*}{ NDG } & Calculated $\gamma_{\mathrm{d}}\left(\mathrm{lb} / \mathrm{ft}^{3}\right)$ & 115.94 & 105.43 & 105.42 & 104.58 & 104.02 & 103.98 & 104.23 & 105.68 \\
\hline & $\begin{array}{l}\text { Device moisture } \\
\text { content (wt\%) }\end{array}$ & 10.60 & 3.55 & 3.55 & 4.05 & 3.65 & 3.95 & 3.90 & 5.10 \\
\hline & \begin{tabular}{|c|}
$\begin{array}{c}\text { Lab moisture content } \\
\text { (wt\%) }\end{array}$ \\
\end{tabular} & 11.33 & 4.67 & 4.68 & 5.23 & 4.70 & 5.17 & 5.25 & 5.43 \\
\hline \multirow[b]{2}{*}{ DCP } & Blows/150mm & 0 & 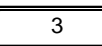 & 4 & 2.00 & 2.00 & 2.00 & 3.00 & 4 \\
\hline & \begin{tabular}{|c|} 
Lab moisture content \\
(wt $\%)$
\end{tabular} & 11.33 & 4.67 & 4.68 & 5.23 & 4.70 & 5.17 & 5.25 & 5.43 \\
\hline \multirow{2}{*}{ ss } & Calculated $\gamma_{\mathrm{d}}\left(\mathrm{lb} / \mathrm{ft}^{3}\right)$ & & & & 111.14 & 100.30 & 100.23 & 100.20 & \\
\hline & \begin{tabular}{|c|}
$\begin{array}{c}\text { Lab moisture content } \\
\text { (wt\%) }\end{array}$ \\
\end{tabular} & & & & 4.93 & 5.02 & 5.35 & 4.93 & \\
\hline \multirow{2}{*}{ Clegg } & Impact Value & & & & 3.10 & 1.80 & 1.70 & 2.60 & 2.6 \\
\hline & \begin{tabular}{|c|}
$\begin{array}{c}\text { Lab moisture content } \\
\text { (wt } \%)\end{array}$ \\
\end{tabular} & & & & 4.87 & 4.86 & 5.51 & 6.33 & 6.33 \\
\hline \multirow[b]{2}{*}{ WB } & Calculated $\gamma_{\mathrm{d}}\left(\mathrm{lb} / \mathrm{ft}^{3}\right)$ & & & & 0.00 & 0.00 & 0.00 & 0.00 & \\
\hline & \begin{tabular}{|c|}
$\begin{array}{c}\text { Lab moisture content } \\
\text { (wt } \%)\end{array}$ \\
\end{tabular} & & & & 0.00 & 5.42 & 0.00 & 0.00 & \\
\hline \multirow[b]{2}{*}{ SC } & Calculated $\gamma_{\mathrm{d}}\left(\mathrm{lb} / \mathrm{ft}^{3}\right)$ & & & & 105.83 & 105.17 & 102.76 & 110.73 & \\
\hline & \begin{tabular}{|c|} 
Lab moisture content \\
(wt $\%)$
\end{tabular} & & & & 4.74 & 5.42 & 4.50 & 5.28 & \\
\hline \multirow{3}{*}{ GG } & Modulus (ksi) -Avg & & & & 3.95 & 3.97 & 4.71 & 4.08 & 3.03 \\
\hline & $\begin{array}{c}\text { Stiffness (kip/in.) - } \\
\text { Avg }\end{array}$ & & & & 17.89 & 18.03 & 21.35 & 18.49 & 13.76 \\
\hline & \begin{tabular}{|c|}
$\begin{array}{c}\text { Lab moisture content } \\
\text { (wt } \%)\end{array}$ \\
\end{tabular} & & & & 5.28 & 3.61 & 3.62 & 4.58 & 5.52 \\
\hline \multirow{3}{*}{ SDG } & Calculated $\gamma_{\mathrm{d}}\left(\mathrm{lb} / \mathrm{ft}^{3}\right)$ & & 97.58 & 102.26 & 102.27 & 105.62 & 99.55 & 98.71 & 102.67 \\
\hline & $\begin{array}{l}\text { Device moisture } \\
\text { content (wt \%) }\end{array}$ & & 0.9 & 2.60 & 2.60 & 3.10 & 1.70 & 1.40 & 3.50 \\
\hline & \begin{tabular}{|c|}
$\begin{array}{c}\text { Lab moisture content } \\
\text { (wt\%) }\end{array}$ \\
\end{tabular} & & 2.91 & 4.96 & 5.22 & 5.02 & 4.74 & 4.72 & 5.20 \\
\hline \multirow{3}{*}{ MDI } & Calculated $\gamma_{\mathrm{d}}\left(\mathrm{lb} / \mathrm{ft}^{3}\right)$ & & & & 106.42 & 106.42 & 106.83 & 105.05 & 106.46 \\
\hline & $\begin{array}{l}\text { Device moisture } \\
\text { content (wt\%) }\end{array}$ & & & & 0.10 & 0.10 & 0.10 & 0.10 & 1.30 \\
\hline & \begin{tabular}{|c|} 
Lab moisture content \\
(wt $\%)$
\end{tabular} & & & & 4.47 & 4.47 & 4.19 & 5.70 & 5.54 \\
\hline \multirow{3}{*}{ EDG } & Calculated $\gamma_{\mathrm{d}}\left(\mathrm{lb} / \mathrm{ft}^{3}\right)$ & & & & 103.77 & 103.92 & 102.38 & 101.49 & 106.06 \\
\hline & $\begin{array}{c}\text { Device moisture } \\
\text { content (wt } \%)\end{array}$ & & & & 3.60 & 5.10 & 5.70 & 6.70 & 14.10 \\
\hline & \begin{tabular}{|c|}
$\begin{array}{c}\text { Lab moisture content } \\
\text { (wt } \%)\end{array}$ \\
\end{tabular} & & & & 5.06 & 5.44 & 4.85 & 5.15 & 6.06 \\
\hline \multirow{3}{*}{ ZFW } & $\mathrm{s}(\mathrm{mm})$ & & & & 1.44 & 2.23 & 2.40 & 2.12 & 1.87 \\
\hline & $\mathrm{E}\left(\mathrm{MN} / \mathrm{m}^{2}\right)$ & & & & 20.80 & 13.50 & 12.50 & 14.10 & 16.00 \\
\hline & \begin{tabular}{|c|} 
Lab moisture content \\
(wt $\%)$
\end{tabular} & & & & 6.18 & 5.23 & 4.81 & 14.15 & 4.82 \\
\hline \multirow{3}{*}{ DFW } & Defl (um) -Avg & & & & 1732.67 & 1674.00 & 2203.00 & 2256.00 & 1778.00 \\
\hline & Emod (Mpa)- Avg & & & & 14.67 & 15.67 & 11.67 & 12.67 & 14.67 \\
\hline & \begin{tabular}{|c|} 
Lab moisture content \\
(wt $\%)$
\end{tabular} & & & & 5.22 & 6.12 & 4.95 & 14.11 & 6.42 \\
\hline
\end{tabular}


SP Soil - Test Item 2

\begin{tabular}{|c|c|c|c|c|c|c|c|c|c|}
\hline $\begin{array}{c}\text { Section } \\
4\end{array}$ & & Base & $\begin{array}{l}\text { Lift 1- } \\
\text { Pass } 8\end{array}$ & $\begin{array}{c}\text { Lift } 2 \\
\text { Pass } 8\end{array}$ & $\begin{array}{c}\text { Lift } 3 \\
\text { Pass } 1\end{array}$ & $\begin{array}{c}\text { Lift } 3 \\
\text { Pass } 2\end{array}$ & $\begin{array}{c}\text { Lift } 3 \\
\text { Pass } 4\end{array}$ & $\begin{array}{c}\text { Lift } 3 \\
\text { Pass } 8\end{array}$ & \begin{tabular}{|c|} 
Lift 3 \\
Pass $8 W$ \\
\end{tabular} \\
\hline \multirow{3}{*}{ NDG } & Calculated $\gamma_{\mathrm{d}}\left(\mathrm{lb} / \mathrm{ft}^{3}\right)$ & 110.83 & 105.61 & 105.36 & 103.92 & 104.42 & 109.00 & 98.02 & 105.91 \\
\hline & $\begin{array}{l}\text { Device moisture } \\
\text { content (wt\%) }\end{array}$ & 10.45 & 3.65 & 3.75 & 3.95 & 3.75 & 3.70 & 3.75 & 5.40 \\
\hline & $\begin{array}{c}\text { Lab moisture content } \\
(\mathrm{wt} \%)\end{array}$ & 12.04 & 4.68 & 4.91 & 4.92 & 4.94 & 0.00 & 11.33 & 6.19 \\
\hline \multirow[b]{2}{*}{ DCP } & Blows/150mm & 0 & 4 & 3 & 2.00 & 3.00 & 3.00 & 4.00 & 5 \\
\hline & $\begin{array}{c}\text { Lab moisture content } \\
(\mathrm{wt} \%)\end{array}$ & 12.04 & 4.68 & 4.91 & 4.92 & 4.94 & 0.00 & 11.33 & 6.19 \\
\hline \multirow[b]{2}{*}{ SS } & Calculated $\gamma_{\mathrm{d}}\left(\mathrm{lb} / \mathrm{ft}^{3}\right)$ & & & & 111.45 & 112.40 & 103.12 & 105.86 & \\
\hline & \begin{tabular}{|c|}
$\begin{array}{c}\text { Lab moisture content } \\
(\mathrm{wt} \%)\end{array}$ \\
\end{tabular} & & & & 5.63 & 4.42 & 5.05 & 4.11 & \\
\hline \multirow[b]{2}{*}{ Clegg } & Impact Vahue & & & & 2.50 & 3.30 & 3.00 & 4.20 & 4.2 \\
\hline & \begin{tabular}{|c}
$\begin{array}{c}\text { Lab moisture content } \\
(\mathrm{wt} \%)\end{array}$ \\
\end{tabular} & & & & 4.95 & 4.92 & 4.17 & 6.01 & 6.01 \\
\hline \multirow[b]{2}{*}{ WB } & Calculated $\gamma_{\mathrm{d}}\left(\mathrm{lb} / \mathrm{ft}^{3}\right)$ & & & & 0.00 & 0.00 & 0.00 & 0.00 & \\
\hline & \begin{tabular}{|c|}
$\begin{array}{c}\text { Lab moisture content } \\
(\mathrm{wt} \%)\end{array}$ \\
\end{tabular} & & & & 0.00 & 5.47 & 0.00 & 0.00 & \\
\hline \multirow[b]{2}{*}{ SC } & Calculated $\gamma_{\mathrm{d}}\left(\mathrm{lb} / \mathrm{ft}^{3}\right)$ & & & & 106.58 & 109.18 & 104.98 & 106.29 & \\
\hline & \begin{tabular}{|c}
$\begin{array}{c}\text { Lab moisture content } \\
(\mathrm{wt} \%)\end{array}$ \\
\end{tabular} & & & & 5.51 & 5.47 & 4.65 & 3.90 & \\
\hline \multirow{3}{*}{ GG } & Modulus (ksi) -Avg & & & & 4.18 & 4.04 & 4.29 & 4.31 & 3.45 \\
\hline & $\begin{array}{c}\text { Stiffness (kip/in.) - } \\
\text { Avg }\end{array}$ & & & & 18.96 & 18.33 & 19.42 & 19.54 & 16.54 \\
\hline & \begin{tabular}{|c} 
Lab moisture content \\
$(\mathrm{wt} \%)$
\end{tabular} & & & & 4.83 & 4.55 & 4.58 & 5.59 & 5.66 \\
\hline \multirow{3}{*}{ SDG } & Calculated $\gamma_{\mathrm{d}}\left(\mathrm{lb} / \mathrm{ft}^{3}\right)$ & & 102.79 & 105.66 & 97.85 & 104.47 & 101.23 & 96.85 & 95.78 \\
\hline & $\begin{array}{c}\text { Device moisture } \\
\text { content (wt } \%)\end{array}$ & & 2.7 & 3.30 & 1.60 & 2.10 & 2.10 & 1.00 & 1.00 \\
\hline & \begin{tabular}{|c}
$\begin{array}{c}\text { Lab moisture content } \\
(\mathrm{wt} \%)\end{array}$ \\
\end{tabular} & & 5.09 & 5.07 & 5.37 & 4.68 & 5.22 & 4.77 & 5.82 \\
\hline \multirow{3}{*}{ MDI } & Calculated $\gamma_{\mathrm{d}}\left(\mathrm{lb} / \mathrm{ft}^{3}\right)$ & & & & 105.89 & 105.88 & 105.91 & 106.00 & 105.40 \\
\hline & $\begin{array}{c}\text { Device moisture } \\
\text { content (wt } \%)\end{array}$ & & & & 0.40 & 0.40 & 0.10 & 0.00 & 0.30 \\
\hline & \begin{tabular}{|c}
$\begin{array}{c}\text { Lab moisture content } \\
(\mathrm{wt} \%)\end{array}$ \\
\end{tabular} & & & & 5.20 & 5.21 & 5.01 & 4.85 & 5.30 \\
\hline \multirow{3}{*}{ EDG } & Calculated $\gamma_{\mathrm{d}}\left(\mathrm{lb} / \mathrm{ft}^{3}\right)$ & & & & 103.39 & 103.32 & 102.85 & 97.52 & 106.99 \\
\hline & $\begin{array}{c}\text { Device moisture } \\
\text { content (wt } \%)\end{array}$ & & & & 4.30 & 3.80 & 6.10 & 0.40 & 10.50 \\
\hline & \begin{tabular}{|c} 
Lab moisture content \\
$(\mathrm{wt} \%)$
\end{tabular} & & & & 5.23 & 5.21 & 5.03 & 4.77 & 4.64 \\
\hline \multirow{3}{*}{ ZFW } & $\mathrm{s}(\mathrm{mm})$ & & & & 2.86 & 2.18 & 1.76 & 1.37 & 1.56 \\
\hline & $\mathrm{E}\left(\mathrm{MN} / \mathrm{m}^{2}\right)$ & & & & 10.50 & 13.70 & 17.10 & 21.90 & 19.20 \\
\hline & \begin{tabular}{|c|}
$\begin{array}{c}\text { Lab moisture content } \\
(\mathrm{wt} \%)\end{array}$ \\
\end{tabular} & & & & Inc. Values & 4.98 & 4.86 & 12.08 & 5.37 \\
\hline \multirow{3}{*}{ DFW } & Defl (um) -Avg & & & & 2019.00 & 2052.67 & 2084.67 & 1710.00 & 1914.33 \\
\hline & Emod (Mpa)- Avg & & & & 12.33 & 12.67 & 13.00 & 15.33 & 14.33 \\
\hline & \begin{tabular}{|c}
$\begin{array}{c}\text { Lab moisture content } \\
(\mathrm{wt} \%)\end{array}$ \\
\end{tabular} & & & & 5.44 & 6.92 & 5.32 & 17.49 & 6.23 \\
\hline
\end{tabular}


ML-3 Soil - Test Item 3

\begin{tabular}{|c|c|c|c|c|c|c|c|c|c|}
\hline $\begin{array}{c}\text { Section } \\
1\end{array}$ & & Base & $\begin{array}{c}\text { Lift 1- } \\
\text { Pass } 8\end{array}$ & $\begin{array}{c}\text { Lift } 2 \\
\text { Pass } 8\end{array}$ & $\begin{array}{c}\text { Lift } 3 \\
\text { Pass } 1\end{array}$ & $\begin{array}{c}\text { Lift } 3 \\
\text { Pass } 2\end{array}$ & $\begin{array}{c}\text { Lift } 3 \\
\text { Pass } 4\end{array}$ & $\begin{array}{c}\text { Lift } 3 \\
\text { Pass } 8\end{array}$ & \begin{tabular}{|c|} 
Lift 3 \\
Pass $8 \mathrm{~W}$ \\
\end{tabular} \\
\hline \multirow{3}{*}{ NDG } & Calculated $\gamma_{\mathrm{d}}\left(\mathrm{lb} / \mathrm{ft}^{3}\right)$ & 110.66 & 116.98 & 115.98 & 113.07 & 116.88 & 115.94 & 114.34 & 112.82 \\
\hline & $\begin{array}{c}\text { Device moisture } \\
\text { content (wt\%) }\end{array}$ & 10.70 & 11.35 & 12.25 & 10.20 & 11.05 & 9.65 & 8.50 & 10.50 \\
\hline & \begin{tabular}{|c|}
$\begin{array}{c}\text { Lab moisture content } \\
(\mathrm{wt} \%)\end{array}$ \\
\end{tabular} & 9.41 & 11.81 & 12.17 & 11.56 & 10.88 & 10.23 & 9.79 & 12.24 \\
\hline \multirow[b]{2}{*}{ DCP } & Blows/150mm & 23 & 6 & 5 & 8.00 & 9.00 & 10.00 & 11.00 & 16 \\
\hline & \begin{tabular}{|c|}
$\begin{array}{c}\text { Lab moisture content } \\
(\mathrm{wt} \%)\end{array}$ \\
\end{tabular} & 9.41 & 11.81 & 12.17 & 11.56 & 10.88 & 10.23 & 9.79 & 12.24 \\
\hline \multirow{2}{*}{ sS } & Calculated $\gamma_{\mathrm{d}}\left(\mathrm{lb} / \mathrm{ft}^{3}\right)$ & & & & 104.80 & 113.79 & 111.79 & 118.15 & \\
\hline & \begin{tabular}{|c|}
$\begin{array}{c}\text { Lab moisture content } \\
(\mathrm{wt} \%)\end{array}$ \\
\end{tabular} & & & & 10.27 & 10.82 & 10.57 & 10.90 & \\
\hline \multirow{2}{*}{ Clegg } & Impact Value & & & & 5.70 & 7.30 & 6.20 & 10.10 & 7.7 \\
\hline & \begin{tabular}{|c|}
$\begin{array}{c}\text { Lab moisture content } \\
\text { (wt } \%)\end{array}$ \\
\end{tabular} & & & & 12.28 & 10.82 & 9.99 & 8.86 & 14.01 \\
\hline \multirow[b]{2}{*}{ WB } & Calculated $\gamma_{\mathrm{d}}\left(\mathrm{lb} / \mathrm{ft}^{3}\right)$ & & & & 77.65 & 94.08 & 179.82 & 185.18 & \\
\hline & \begin{tabular}{|c|}
$\begin{array}{c}\text { Lab moisture content } \\
\text { (wt } \%)\end{array}$ \\
\end{tabular} & & & & 11.49 & 12.12 & 11.22 & 10.39 & \\
\hline \multirow[b]{2}{*}{ SC } & Calculated $\gamma_{\mathrm{d}}\left(\mathrm{lb} / \mathrm{ft}^{3}\right)$ & & & & 116.78 & 118.20 & 122.95 & 118.44 & \\
\hline & \begin{tabular}{|c|}
$\begin{array}{c}\text { Lab moisture content } \\
\text { (wt } \%)\end{array}$ \\
\end{tabular} & & & & 12.93 & 12.12 & 11.41 & 9.88 & \\
\hline \multirow{3}{*}{ GG } & Modulus (ksi) -Avg & & & & 12.27 & 10.55 & 5.89 & 7.81 & 10.38 \\
\hline & $\begin{array}{c}\text { Stiffness (kip/in.) - } \\
\text { Avg }\end{array}$ & & & & 55.63 & 47.85 & 26.72 & 35.42 & 47.07 \\
\hline & $\begin{array}{c}\text { Lab moisture content } \\
(\mathrm{wt} \%)\end{array}$ & & & & 14.12 & 10.80 & 11.20 & 9.52 & 13.59 \\
\hline \multirow{3}{*}{ SDG } & Calculated $\gamma_{\mathrm{d}}\left(\mathrm{lb} / \mathrm{ft}^{3}\right)$ & & 112.20 & 111.04 & 103.05 & 103.71 & 107.36 & 86.80 & 101.59 \\
\hline & $\begin{array}{c}\text { Device moisture } \\
\text { content (wt } \%)\end{array}$ & & 5.2 & 5.20 & 3.70 & 3.70 & 2.90 & -1.10 & 3.50 \\
\hline & \begin{tabular}{|c|}
$\begin{array}{c}\text { Lab moisture content } \\
\text { (wt } \%)\end{array}$ \\
\end{tabular} & & 11.79 & 12.43 & 12.15 & 12.63 & 5.58 & 9.49 & 12.42 \\
\hline \multirow{3}{*}{ MDI } & Calculated $\gamma_{\mathrm{d}}\left(\mathrm{lb} / \mathrm{ft}^{3}\right)$ & & & & 87.25 & 83.37 & 74.42 & 81.34 & 85.38 \\
\hline & $\begin{array}{c}\text { Device moisture } \\
\text { content (wt\%) }\end{array}$ & & & & 9.60 & 10.10 & 11.30 & 10.60 & 9.90 \\
\hline & \begin{tabular}{|c|}
$\begin{array}{c}\text { Lab moisture content } \\
(\mathrm{wt} \%)\end{array}$ \\
\end{tabular} & & & & 14.63 & 13.07 & 11.19 & 9.82 & 13.23 \\
\hline \multirow{3}{*}{ EDG } & Calculated $\gamma_{\mathrm{d}}\left(\mathrm{lb} / \mathrm{ft}^{3}\right)$ & & & & 100.54 & 111.13 & 109.48 & 113.33 & 109.23 \\
\hline & $\begin{array}{c}\text { Device moisture } \\
\text { content (wt } \% \text { ) }\end{array}$ & & & & 9.90 & 12.60 & 126.00 & 12.20 & 13.10 \\
\hline & \begin{tabular}{|c|}
$\begin{array}{c}\text { Lab moisture content } \\
\text { (wt } \%)\end{array}$ \\
\end{tabular} & & & & 12.50 & 11.59 & 11.21 & 10.34 & 13.10 \\
\hline \multirow{3}{*}{ ZFW } & $\mathrm{s}(\mathrm{mm})$ & & & & 3.19 & 4.41 & 4.41 & 4.04 & 3.75 \\
\hline & $\mathrm{E}\left(\mathrm{MN} / \mathrm{m}^{2}\right)$ & & & & 9.40 & 6.80 & 6.80 & 7.40 & 8.00 \\
\hline & \begin{tabular}{|c|}
$\begin{array}{c}\text { Lab moisture content } \\
\text { (wt } \%)\end{array}$ \\
\end{tabular} & & & & 11.30 & 12.14 & 11.82 & 11.01 & 14.98 \\
\hline \multirow{3}{*}{ DFW } & Defl (um) -Avg & & & & 1859.33 & 1606.00 & 1927.67 & 1914.33 & 1994.67 \\
\hline & Emod (Mpa)- Avg & & & & 10.00 & 11.67 & 9.00 & 10.00 & 13.33 \\
\hline & \begin{tabular}{|c|}
$\begin{array}{c}\text { Lab moisture content } \\
(\mathrm{wt} \%)\end{array}$ \\
\end{tabular} & & & & 9.77 & 12.07 & 11.21 & 11.64 & 14.06 \\
\hline
\end{tabular}


ML-3 Soil - Test Item 3

\begin{tabular}{|c|c|c|c|c|c|c|c|c|c|}
\hline $\begin{array}{c}\text { Section } \\
2\end{array}$ & & Base & $\begin{array}{c}\text { Lift 1- } \\
\text { Pass } 8\end{array}$ & $\begin{array}{c}\text { Lift } 2 \\
\text { Pass } 8\end{array}$ & $\begin{array}{c}\text { Lift } 3 \\
\text { Pass } 1\end{array}$ & $\begin{array}{c}\text { Lift } 3 \\
\text { Pass } 2\end{array}$ & $\begin{array}{c}\text { Lift } 3 \\
\text { Pass } 4\end{array}$ & $\begin{array}{c}\text { Lift } 3 \\
\text { Pass } 8\end{array}$ & \begin{tabular}{|c|} 
Lift 3 \\
Pass $8 \mathrm{~W}$ \\
\end{tabular} \\
\hline \multirow{3}{*}{ NDG } & Calculated $\gamma_{\mathrm{d}}\left(\mathrm{lb} / \mathrm{ft}^{3}\right)$ & 113.09 & 116.79 & 115.80 & 99.71 & 112.65 & 112.82 & 115.05 & 110.49 \\
\hline & $\begin{array}{c}\text { Device moisture } \\
\text { content (wt\%) }\end{array}$ & 8.90 & 11.40 & 11.70 & 10.45 & 10.40 & 10.40 & 9.45 & 11.15 \\
\hline & \begin{tabular}{|c|}
$\begin{array}{c}\text { Lab moisture content } \\
(\mathrm{wt} \%)\end{array}$ \\
\end{tabular} & 8.65 & 11.76 & 12.24 & 14.19 & 11.02 & 12.17 & 9.73 & 13.48 \\
\hline \multirow[b]{2}{*}{ DCP } & Blows/150mm & 22 & 6 & 7 & 6.00 & 11.00 & 8.00 & 10.00 & 14 \\
\hline & \begin{tabular}{|c|}
$\begin{array}{c}\text { Lab moisture content } \\
(\mathrm{wt} \%)\end{array}$ \\
\end{tabular} & 8.65 & 11.76 & 12.24 & 14.19 & 11.02 & 12.17 & 9.73 & 13.48 \\
\hline \multirow[b]{2}{*}{ SS } & Calculated $\gamma_{\mathrm{d}}\left(\mathrm{lb} / \mathrm{ft}^{3}\right)$ & & & & 101.85 & 101.84 & 112.39 & 111.08 & \\
\hline & \begin{tabular}{|c|}
$\begin{array}{c}\text { Lab moisture content } \\
(\mathrm{wt} \%)\end{array}$ \\
\end{tabular} & & & & 11.59 & 11.67 & 11.64 & 11.14 & \\
\hline \multirow{2}{*}{ Clegg } & Impact Value & & & & 5.80 & 8.90 & 8.50 & 8.40 & 7 \\
\hline & \begin{tabular}{|c|}
$\begin{array}{c}\text { Lab moisture content } \\
\text { (wt } \%)\end{array}$ \\
\end{tabular} & & & & 11.82 & 10.59 & 10.36 & 7.89 & 14.79 \\
\hline \multirow[b]{2}{*}{ WB } & Calculated $\gamma_{\mathrm{d}}\left(\mathrm{lb} / \mathrm{ft}^{3}\right)$ & & & & 99.36 & 91.70 & 168.54 & 179.31 & \\
\hline & \begin{tabular}{|c|}
$\begin{array}{c}\text { Lab moisture content } \\
\text { (wt\%) }\end{array}$ \\
\end{tabular} & & & & 12.47 & 12.01 & 10.39 & 10.17 & \\
\hline \multirow[b]{2}{*}{ SC } & Calculated $\gamma_{\mathrm{d}}\left(\mathrm{lb} / \mathrm{ft}^{3}\right)$ & & & & 115.87 & 120.50 & 122.12 & 120.79 & \\
\hline & \begin{tabular}{|c|}
$\begin{array}{c}\text { Lab moisture content } \\
\text { (wt } \%)\end{array}$ \\
\end{tabular} & & & & 12.58 & 12.01 & 11.04 & 10.19 & \\
\hline \multirow{3}{*}{ GG } & Modulus (ksi) -Avg & & & & 12.65 & 9.81 & 6.58 & 9.51 & 11.56 \\
\hline & $\begin{array}{c}\text { Stiffness (kip/in.) - } \\
\text { Avg }\end{array}$ & & & & 57.38 & 44.51 & 29.85 & 43.13 & 52.43 \\
\hline & $\begin{array}{c}\text { Lab moisture content } \\
(\mathrm{wt} \%)\end{array}$ & & & & 12.42 & 11.02 & 10.24 & 8.59 & 12.24 \\
\hline \multirow{3}{*}{ SDG } & Calculated $\gamma_{\mathrm{d}}\left(\mathrm{lb} / \mathrm{ft}^{3}\right)$ & & 112.20 & 113.36 & 94.15 & 102.69 & 88.91 & 90.02 & 104.37 \\
\hline & $\begin{array}{c}\text { Device moisture } \\
\text { content (wt } \%)\end{array}$ & & 5.3 & 5.00 & 2.10 & 3.40 & 2.00 & -0.50 & 4.20 \\
\hline & \begin{tabular}{|c|}
$\begin{array}{c}\text { Lab moisture content } \\
\text { (wt } \%)\end{array}$ \\
\end{tabular} & & 11.79 & 11.51 & 11.68 & 11.55 & 12.06 & 9.25 & 11.85 \\
\hline \multirow{3}{*}{ MDI } & Calculated $\gamma_{\mathrm{d}}\left(\mathrm{lb} / \mathrm{ft}^{3}\right)$ & & & & 75.54 & 83.22 & 82.49 & 86.57 & 87.76 \\
\hline & $\begin{array}{c}\text { Device moisture } \\
\text { content (wt\%) }\end{array}$ & & & & 11.10 & 10.20 & 10.90 & 10.10 & 9.80 \\
\hline & \begin{tabular}{|c|}
$\begin{array}{c}\text { Lab moisture content } \\
(\mathrm{wt} \%)\end{array}$ \\
\end{tabular} & & & & 11.65 & 11.66 & 4.86 & 9.35 & 11.80 \\
\hline \multirow{3}{*}{ EDG } & Calculated $\gamma_{\mathrm{d}}\left(\mathrm{lb} / \mathrm{ft}^{3}\right)$ & & & & 85.23 & 111.18 & 109.05 & 111.62 & 107.83 \\
\hline & $\begin{array}{c}\text { Device moisture } \\
\text { content (wt } \%)\end{array}$ & & & & 9.90 & 12.60 & 11.60 & 12.00 & 12.30 \\
\hline & \begin{tabular}{|c|}
$\begin{array}{c}\text { Lab moisture content } \\
\text { (wt } \%)\end{array}$ \\
\end{tabular} & & & & 11.77 & 11.41 & 10.91 & 10.85 & 13.67 \\
\hline \multirow{3}{*}{ ZFW } & $\mathrm{s}(\mathrm{mm})$ & & & & 3.02 & 2.51 & 3.10 & 3.49 & 3.67 \\
\hline & $\mathrm{E}\left(\mathrm{MN} / \mathrm{m}^{2}\right)$ & & & & 9.90 & 12.00 & 9.70 & 8.60 & 8.20 \\
\hline & \begin{tabular}{|c|}
$\begin{array}{c}\text { Lab moisture content } \\
\text { (wt } \%)\end{array}$ \\
\end{tabular} & & & & 11.65 & 12.01 & 10.62 & 9.69 & 13.30 \\
\hline \multirow{3}{*}{ DFW } & Defl (um) -Avg & & & & 1815.67 & 1463.67 & 1378.67 & 1472.67 & 1509.67 \\
\hline & Emod (Mpa)- Avg & & & & 16.33 & 12.67 & 11.33 & 13.00 & 17.33 \\
\hline & \begin{tabular}{|c|}
$\begin{array}{c}\text { Lab moisture content } \\
(\mathrm{wt} \%)\end{array}$ \\
\end{tabular} & & & & 11.47 & 11.69 & 11.16 & 9.23 & 12.19 \\
\hline
\end{tabular}


ML-3 Soil - Test Item 3

\begin{tabular}{|c|c|c|c|c|c|c|c|c|c|}
\hline $\begin{array}{c}\text { Section } \\
3 \\
\end{array}$ & & Base & $\begin{array}{c}\text { Lift 1- } \\
\text { Pass } 8 \\
\end{array}$ & $\begin{array}{c}\text { Lift } 2 \\
\text { Pass } 8 \\
\end{array}$ & $\begin{array}{c}\text { Lift } 3 \\
\text { Pass } 1 \\
\end{array}$ & $\begin{array}{c}\text { Lift } 3 \\
\text { Pass } 2 \\
\end{array}$ & $\begin{array}{c}\text { Lift } 3 \\
\text { Pass } 4 \\
\end{array}$ & $\begin{array}{c}\text { Lift } 3 \\
\text { Pass } 8 \\
\end{array}$ & $\begin{array}{c}\text { Lift } 3 \\
\text { Pass 8W } \\
\end{array}$ \\
\hline \multirow{3}{*}{ NDG } & Calculated $\gamma_{\mathrm{d}}\left(\mathrm{lb} / \mathrm{ft}^{3}\right)$ & 110.48 & 117.85 & 115.23 & 108.67 & 109.91 & 112.74 & 116.54 & 114.85 \\
\hline & $\begin{array}{c}\text { Device moisture } \\
\text { content (wt\%) }\end{array}$ & 9.75 & 11.00 & 11.60 & 10.85 & 10.45 & 10.50 & 9.45 & 11.20 \\
\hline & $\begin{array}{c}\text { Lab moisture content } \\
\text { (wt } \%)\end{array}$ & 11.26 & 11.56 & 12.44 & 12.08 & 10.53 & 10.42 & 10.90 & 12.23 \\
\hline \multirow[b]{2}{*}{ DCP } & Blows/150mm & 20 & 13 & 6 & 8.00 & 6.00 & 8.00 & 12.00 & 17 \\
\hline & \begin{tabular}{|c|}
$\begin{array}{c}\text { Lab moisture content } \\
\text { (wt } \%)\end{array}$ \\
\end{tabular} & 11.26 & 11.56 & 12.44 & 12.08 & 10.53 & 10.42 & 10.90 & 12.23 \\
\hline \multirow{2}{*}{ sS } & Calculated $\gamma_{\mathrm{d}}\left(\mathrm{lb} / \mathrm{ft}^{3}\right)$ & & & & 100.00 & 107.35 & 117.96 & 125.61 & \\
\hline & \begin{tabular}{|c|}
$\begin{array}{c}\text { Lab moisture content } \\
(\mathrm{wt} \%)\end{array}$ \\
\end{tabular} & & & & 11.03 & 11.21 & 10.02 & 10.60 & \\
\hline \multirow{2}{*}{ Clegg } & Impact Value & & & & 9.80 & 10.80 & 8.50 & 9.30 & 13.7 \\
\hline & \begin{tabular}{|c|}
$\begin{array}{c}\text { Lab moisture content } \\
\text { (wt } \%)\end{array}$ \\
\end{tabular} & & & & 10.24 & 10.51 & 11.18 & 8.51 & 11.51 \\
\hline \multirow[b]{2}{*}{ WB } & Calculated $\gamma_{\mathrm{d}}\left(\mathrm{lb} / \mathrm{ft}^{3}\right)$ & & & & 98.83 & 98.05 & 150.11 & 102.69 & \\
\hline & \begin{tabular}{|c|}
$\begin{array}{c}\text { Lab moisture content } \\
\text { (wt } \%)\end{array}$ \\
\end{tabular} & & & & 11.43 & 11.02 & 10.71 & 10.18 & \\
\hline \multirow[b]{2}{*}{ SC } & Calculated $\gamma_{\mathrm{d}}\left(\mathrm{lb} / \mathrm{ft}^{3}\right)$ & & & & 119.41 & 117.63 & 113.05 & 117.91 & \\
\hline & \begin{tabular}{|c|}
$\begin{array}{c}\text { Lab moisture content } \\
\text { (wt } \%)\end{array}$ \\
\end{tabular} & & & & 11.13 & 11.02 & 10.40 & 10.49 & \\
\hline \multirow{3}{*}{ GG } & Modulus (ksi) -Avg & & & & 13.12 & 9.56 & 8.44 & 11.17 & 10.27 \\
\hline & $\begin{array}{c}\text { Stiffness (kip/in.) - } \\
\text { Avg } \\
\end{array}$ & & & & 59.51 & 43.38 & 38.31 & 51.00 & 47.75 \\
\hline & $\begin{array}{c}\text { Lab moisture content } \\
(\mathrm{wt} \%)\end{array}$ & & & & 11.46 & 11.50 & 10.10 & 9.29 & 12.05 \\
\hline \multirow{3}{*}{ SDG } & Calculated $\gamma_{\mathrm{d}}\left(\mathrm{lb} / \mathrm{ft}^{3}\right)$ & & 111.90 & 99.28 & 96.48 & 102.99 & 87.67 & 84.65 & 103.70 \\
\hline & $\begin{array}{c}\text { Device moisture } \\
\text { content (wt } \%)\end{array}$ & & 5.1 & 2.40 & 2.50 & 3.10 & -0.70 & -1.80 & 4.10 \\
\hline & \begin{tabular}{|c|}
$\begin{array}{c}\text { Lab moisture content } \\
\text { (wt } \%)\end{array}$ \\
\end{tabular} & & 11.61 & 10.72 & 11.32 & 10.68 & 10.81 & 9.66 & 12.93 \\
\hline \multirow{3}{*}{ MDI } & Calculated $\gamma_{\mathrm{d}}\left(\mathrm{lb} / \mathrm{ft}^{3}\right)$ & & & & 77.61 & 81.58 & 83.24 & 75.36 & 67.37 \\
\hline & $\begin{array}{c}\text { Device moisture } \\
\text { content (wt } \%)\end{array}$ & & & & 10.80 & 10.30 & 10.40 & 11.20 & 10.90 \\
\hline & \begin{tabular}{|c|}
$\begin{array}{c}\text { Lab moisture content } \\
(\mathrm{wt} \%)\end{array}$ \\
\end{tabular} & & & & 12.01 & 12.37 & 9.72 & 10.50 & 14.40 \\
\hline \multirow{3}{*}{ EDG } & Calculated $\gamma_{\mathrm{d}}\left(\mathrm{lb} / \mathrm{ft}^{3}\right)$ & & & & 98.05 & 111.20 & 109.54 & 110.67 & 109.59 \\
\hline & $\begin{array}{c}\text { Device moisture } \\
\text { content (wt } \% \text { ) }\end{array}$ & & & & 9.50 & 11.90 & 11.80 & 11.30 & 13.00 \\
\hline & \begin{tabular}{|c|}
$\begin{array}{c}\text { Lab moisture content } \\
\text { (wt } \%)\end{array}$ \\
\end{tabular} & & & & 9.63 & 10.68 & 10.65 & 10.68 & 12.47 \\
\hline \multirow{3}{*}{ ZFW } & $\mathrm{s}(\mathrm{mm})$ & & & & 3.45 & 2.97 & 3.29 & 2.64 & 2.09 \\
\hline & $\mathrm{E}\left(\mathrm{MN} / \mathrm{m}^{2}\right)$ & & & & 8.70 & 10.10 & 9.10 & 11.40 & 14.40 \\
\hline & \begin{tabular}{|c|}
$\begin{array}{c}\text { Lab moisture content } \\
(\mathrm{wt} \%)\end{array}$ \\
\end{tabular} & & & & 11.70 & 11.05 & 11.44 & 10.37 & 11.30 \\
\hline \multirow{3}{*}{ DFW } & Defl (um) -Avg & & & & 1643.00 & 1675.67 & 2025.67 & 1475.33 & 1438.00 \\
\hline & Emod (Mpa)- Avg & & & & 18.67 & 11.33 & 8.67 & 13.00 & 21.00 \\
\hline & \begin{tabular}{|c|}
$\begin{array}{c}\text { Lab moisture content } \\
(\mathrm{wt} \%)\end{array}$ \\
\end{tabular} & & & & 12.04 & 11.06 & 10.07 & 10.46 & 14.46 \\
\hline
\end{tabular}


ML-3 Soil - Test Item 3

\begin{tabular}{|c|c|c|c|c|c|c|c|c|c|}
\hline $\begin{array}{c}\text { Section } \\
4 \\
\end{array}$ & & Base & $\begin{array}{c}\text { Lift 1- } \\
\text { Pass } 8 \\
\end{array}$ & $\begin{array}{c}\text { Lift } 2 \\
\text { Pass } 8 \\
\end{array}$ & $\begin{array}{c}\text { Lift } 3 \\
\text { Pass } 1 \\
\end{array}$ & $\begin{array}{c}\text { Lift } 3 \\
\text { Pass } 2 \\
\end{array}$ & $\begin{array}{c}\text { Lift } 3 \\
\text { Pass } 4 \\
\end{array}$ & $\begin{array}{c}\text { Lift } 3 \\
\text { Pass } 8 \\
\end{array}$ & $\begin{array}{c}\text { Lift } 3 \\
\text { Pass 8W } \\
\end{array}$ \\
\hline \multirow{3}{*}{ NDG } & Calculated $\gamma_{\mathrm{d}}\left(\mathrm{lb} / \mathrm{ft}^{3}\right)$ & 103.72 & 116.43 & 117.52 & 105.28 & 112.92 & 110.30 & 117.03 & 115.35 \\
\hline & $\begin{array}{c}\text { Device moisture } \\
\text { content (wt } \%)\end{array}$ & 11.00 & 11.40 & 11.30 & 11.60 & 10.50 & 10.40 & 10.10 & 11.65 \\
\hline & $\begin{array}{c}\text { Lab moisture content } \\
\text { (wt } \%)\end{array}$ & 13.78 & 12.06 & 12.00 & 12.81 & 11.02 & 12.15 & 10.22 & 11.51 \\
\hline \multirow[b]{2}{*}{ DCP } & Blows/150mm & 17 & 8 & 7 & 5.00 & 7.00 & 7.00 & 12.00 & 15 \\
\hline & $\begin{array}{c}\text { Lab moisture content } \\
\text { (wt } \%)\end{array}$ & 13.78 & 12.06 & 12.00 & 12.81 & 11.02 & 12.15 & 10.22 & 11.51 \\
\hline \multirow[b]{2}{*}{ SS } & Calculated $\gamma_{\mathrm{d}}\left(\mathrm{lb} / \mathrm{ft}^{3}\right)$ & & & & 115.94 & 121.44 & 126.18 & 125.43 & \\
\hline & $\begin{array}{c}\begin{array}{c}\text { Lab moisture content } \\
\text { (wt } \%)\end{array} \\
\end{array}$ & & & & 12.17 & 11.81 & 10.45 & 11.48 & \\
\hline \multirow[b]{2}{*}{ Clegg } & Impact Value & & & & 6.20 & 6.40 & 6.90 & 8.60 & 12.8 \\
\hline & \begin{tabular}{|c|}
$\begin{array}{c}\text { Lab moisture content } \\
(\mathrm{wt} \%)\end{array}$ \\
\end{tabular} & & & & 12.09 & 10.36 & 10.68 & 7.23 & 12.15 \\
\hline \multirow[b]{2}{*}{ WB } & Calculated $\gamma_{\mathrm{d}}\left(\mathrm{lb} / \mathrm{ft}^{3}\right)$ & & & & 129.40 & 143.26 & 202.04 & 249.89 & \\
\hline & \begin{tabular}{|c|}
$\begin{array}{c}\text { Lab moisture content } \\
(\mathrm{wt} \%)\end{array}$ \\
\end{tabular} & & & & 11.25 & 12.10 & 11.50 & 10.21 & \\
\hline \multirow[b]{2}{*}{ SC } & Calculated $\gamma_{\mathrm{d}}\left(\mathrm{lb} / \mathrm{ft}^{3}\right)$ & & & & 116.13 & 112.92 & 113.59 & 114.41 & \\
\hline & $\begin{array}{c}\begin{array}{c}\text { Lab moisture content } \\
\text { (wt } \%)\end{array} \\
\end{array}$ & & & & 11.75 & 12.10 & 10.97 & 10.46 & \\
\hline \multirow{3}{*}{ GG } & Modulus (ksi) -Avg & & & & 12.49 & 9.21 & 8.15 & 10.64 & 11.04 \\
\hline & $\begin{array}{c}\text { Stiffness (kip/in.) - } \\
\text { Avg }\end{array}$ & & & & 56.65 & 41.79 & 36.96 & 48.26 & 50.07 \\
\hline & \begin{tabular}{|c|}
$\begin{array}{c}\text { Lab moisture content } \\
(\mathrm{wt} \%)\end{array}$ \\
\end{tabular} & & & & 13.20 & 11.95 & 11.45 & 11.63 & 12.28 \\
\hline \multirow{3}{*}{ SDG } & Calculated $\gamma_{\mathrm{d}}\left(\mathrm{lb} / \mathrm{ft}^{3}\right)$ & & 115.42 & 114.47 & 103.60 & 92.17 & 86.73 & 85.62 & 99.34 \\
\hline & $\begin{array}{c}\text { Device moisture } \\
\text { content (wt\%) }\end{array}$ & & 5.7 & 5.20 & 4.10 & 0.50 & -1.10 & -2.10 & 3.40 \\
\hline & \begin{tabular}{|c|}
$\begin{array}{c}\text { Lab moisture content } \\
(\mathrm{wt} \%)\end{array}$ \\
\end{tabular} & & 12.23 & 12.01 & 12.72 & 10.6 & 10.68 & 8.43 & 12.94 \\
\hline \multirow{3}{*}{ MDI } & Calculated $\gamma_{\mathrm{d}}\left(\mathrm{lb} / \mathrm{ft}^{3}\right)$ & & & & 81.60 & 82.55 & 87.05 & 89.54 & 66.06 \\
\hline & $\begin{array}{c}\text { Device moisture } \\
\text { content (wt } \%)\end{array}$ & & & & 10.40 & 10.30 & 10.00 & 9.70 & 12.40 \\
\hline & \begin{tabular}{|c|}
$\begin{array}{c}\text { Lab moisture content } \\
\text { (wt } \%)\end{array}$ \\
\end{tabular} & & & & 12.07 & 11.33 & 9.98 & 11.70 & 11.68 \\
\hline \multirow{3}{*}{ EDG } & Calculated $\gamma_{\mathrm{d}}\left(\mathrm{lb} / \mathrm{ft}^{3}\right)$ & & & & 97.93 & 110.29 & 109.02 & 112.36 & 109.87 \\
\hline & $\begin{array}{c}\text { Device moisture } \\
\text { content (wt } \% \text { ) }\end{array}$ & & & & 9.70 & 12.60 & 12.10 & 12.10 & 12.70 \\
\hline & \begin{tabular}{|c|}
$\begin{array}{c}\text { Lab moisture content } \\
\text { (wt } \%)\end{array}$ \\
\end{tabular} & & & & 12.95 & 12.19 & 10.49 & 10.47 & 11.96 \\
\hline \multirow{3}{*}{ ZFW } & s (mm) & & & & 3.16 & 3.58 & 3.33 & 2.74 & 2.77 \\
\hline & $\mathrm{E}\left(\mathrm{MN} / \mathrm{m}^{2}\right)$ & & & & 9.50 & 8.40 & 9.00 & 10.90 & 10.80 \\
\hline & \begin{tabular}{|c|}
$\begin{array}{c}\text { Lab moisture content } \\
\text { (wt } \%)\end{array}$ \\
\end{tabular} & & & & 12.05 & 12.25 & 12.16 & 10.91 & 13.53 \\
\hline \multirow{3}{*}{ DFW } & Defl (um) -Avg & & & & 2115.00 & 1630.33 & 2023.33 & 2042.33 & 1293.67 \\
\hline & Emod (Mpa)- Avg & & & & 14.00 & 11.67 & 8.67 & 8.67 & 20.67 \\
\hline & \begin{tabular}{|c|}
$\begin{array}{c}\text { Lab moisture content } \\
(\mathrm{wt} \%)\end{array}$ \\
\end{tabular} & & & & 11.85 & 12.22 & 11.98 & 10.96 & 12.30 \\
\hline
\end{tabular}


SM Soil - Test Item 4

\begin{tabular}{|c|c|c|c|c|c|c|c|c|c|}
\hline $\begin{array}{c}\text { Section } \\
1 \\
\end{array}$ & & Base & $\begin{array}{l}\text { Lift 1- } \\
\text { Pass } 8 \\
\end{array}$ & $\begin{array}{c}\text { Lift } 2 \\
\text { Pass } 8 \\
\end{array}$ & $\begin{array}{c}\text { Lift } 3 \\
\text { Pass } 1 \\
\end{array}$ & $\begin{array}{c}\text { Lift } 3 \\
\text { Pass } 2 \\
\end{array}$ & $\begin{array}{c}\text { Lift } 3 \\
\text { Pass } 4 \\
\end{array}$ & $\begin{array}{c}\text { Lift } 3 \\
\text { Pass } 8 \\
\end{array}$ & \begin{tabular}{|c|} 
Lift 3 \\
Pass 8W \\
\end{tabular} \\
\hline \multirow{3}{*}{ NDG } & Calculated $\gamma_{\mathrm{d}}\left(\mathrm{lb} / \mathrm{ft}^{3}\right)$ & 108.03 & & 121.06 & 122.82 & 122.75 & 126.98 & 128.14 & 125.51 \\
\hline & $\begin{array}{l}\text { Device moisture } \\
\text { content (wt\%) }\end{array}$ & 12.40 & & 9.25 & 7.05 & 7.15 & 6.80 & 6.25 & 6.90 \\
\hline & \begin{tabular}{|c|}
$\begin{array}{c}\text { Lab moisture content } \\
\text { (wt\%) }\end{array}$ \\
\end{tabular} & 12.88 & & 11.57 & 6.67 & 10.37 & 7.28 & 7.11 & 9.02 \\
\hline \multirow[b]{2}{*}{ DCP } & Blows/150mm & 0 & & 11.57 & 9.00 & 8.00 & 9.00 & 11.00 & 10 \\
\hline & \begin{tabular}{|c|} 
Lab moisture content \\
(wt $\%)$
\end{tabular} & 12.88 & & 11.57 & 6.67 & 10.37 & 7.28 & 7.11 & 9.02 \\
\hline \multirow{2}{*}{ ss } & Calculated $\gamma_{\mathrm{d}}\left(\mathrm{lb} / \mathrm{ft}^{3}\right)$ & & & & 127.33 & 135.36 & 131.56 & 129.28 & \\
\hline & \begin{tabular}{|c|}
$\begin{array}{c}\text { Lab moisture content } \\
\text { (wt\%) }\end{array}$ \\
\end{tabular} & & & & 6.24 & 7.10 & 7.42 & 7.26 & \\
\hline \multirow{2}{*}{ Clegg } & Impact Value & & & & 11.00 & 11.50 & 14.60 & 8.80 & 14.8 \\
\hline & \begin{tabular}{|c|}
$\begin{array}{c}\text { Lab moisture content } \\
\text { (wt } \%)\end{array}$ \\
\end{tabular} & & & & 6.49 & 8.18 & 6.17 & 7.16 & 3.87 \\
\hline \multirow[b]{2}{*}{ WB } & Calculated $\gamma_{\mathrm{d}}\left(\mathrm{lb} / \mathrm{ft}^{3}\right)$ & & & & 117.88 & 116.13 & 123.56 & 117.87 & \\
\hline & \begin{tabular}{|c|}
$\begin{array}{c}\text { Lab moisture content } \\
\text { (wt } \%)\end{array}$ \\
\end{tabular} & & & & 7.58 & 7.11 & 6.96 & 6.47 & \\
\hline \multirow[b]{2}{*}{ SC } & Calculated $\gamma_{\mathrm{d}}\left(\mathrm{lb} / \mathrm{ft}^{3}\right)$ & & & & 128.02 & 127.45 & 132.74 & 131.34 & \\
\hline & \begin{tabular}{|c|} 
Lab moisture content \\
(wt $\%)$
\end{tabular} & & & & 7.30 & 7.11 & 6.26 & 6.92 & \\
\hline \multirow{3}{*}{ GG } & Modulus (ksi) -Avg & & & & (58.02 & 12.92 & 1.86 & 5.58 & 8.35 \\
\hline & $\begin{array}{c}\text { Stiffness (kip/in.) - } \\
\text { Avg }\end{array}$ & & & & 12.78 & 58.62 & 8.43 & 25.32 & 37.88 \\
\hline & \begin{tabular}{|c|} 
Lab moisture content \\
(wt $\%)$
\end{tabular} & & & & 6.17 & 8.14 & 8.24 & 7.53 & 7.22 \\
\hline \multirow{3}{*}{ SDG } & Calculated $\gamma_{\mathrm{d}}\left(\mathrm{lb} / \mathrm{ft}^{3}\right)$ & & & 0.00 & 116.03 & 109.34 & 108.46 & 108.30 & 109.78 \\
\hline & $\begin{array}{l}\text { Device moisture } \\
\text { content (wt \%) }\end{array}$ & & & 11.08 & 1.50 & 1.00 & -0.10 & 0.00 & -0.20 \\
\hline & \begin{tabular}{|c|}
$\begin{array}{c}\text { Lab moisture content } \\
\text { (wt\%) }\end{array}$ \\
\end{tabular} & & & 0.00 & 5.90 & 10.67 & 8.78 & 8.99 & 7.28 \\
\hline \multirow{3}{*}{ MDI } & Calculated $\gamma_{\mathrm{d}}\left(\mathrm{lb} / \mathrm{ft}^{3}\right)$ & & & & 108.70 & 111.72 & 105.76 & 113.62 & 118.91 \\
\hline & $\begin{array}{l}\text { Device moisture } \\
\text { content (wt\%) }\end{array}$ & & & & 3.50 & 3.50 & 1.20 & 3.50 & 7.60 \\
\hline & \begin{tabular}{|c|} 
Lab moisture content \\
(wt $\%)$
\end{tabular} & & & & 11.84 & 8.65 & 10.45 & 7.02 & 8.67 \\
\hline \multirow{3}{*}{ EDG } & Calculated $\gamma_{\mathrm{d}}\left(\mathrm{lb} / \mathrm{ft}^{3}\right)$ & & & & 121.60 & 120.87 & 124.34 & 117.94 & 119.09 \\
\hline & $\begin{array}{c}\text { Device moisture } \\
\text { content (wt } \%)\end{array}$ & & & & 7.60 & 7.40 & 7.60 & 7.50 & 7.60 \\
\hline & \begin{tabular}{|c|} 
Lab moisture content \\
(wt $\%)$
\end{tabular} & & & & 10.06 & 8.50 & 5.73 & 8.50 & 8.53 \\
\hline \multirow{3}{*}{ ZFW } & s (mm) & & & & 3.16 & 4.68 & 4.95 & $\overline{5.02}$ & 4.66 \\
\hline & $\mathrm{E}\left(\mathrm{MN} / \mathrm{m}^{2}\right)$ & & & & 9.50 & 6.40 & 6.10 & 6.00 & 6.40 \\
\hline & \begin{tabular}{|c|} 
Lab moisture content \\
(wt $\%)$
\end{tabular} & & & & 6.45 & 8.96 & 9.95 & 8.44 & 8.06 \\
\hline \multirow{3}{*}{ DFW } & Defl (um) -Avg & & & & 2212.00 & 2096.33 & 2098.33 & 2134.33 & 2328.33 \\
\hline & Emod (Mpa)- Avg & & & & 11.00 & 11.00 & 10.33 & 10.00 & 9.33 \\
\hline & \begin{tabular}{|c|} 
Lab moisture content \\
(wt $\%)$
\end{tabular} & & & & 7.43 & 7.30 & 8.15 & 9.97 & 7.67 \\
\hline
\end{tabular}


SM Soil - Test Item 4

\begin{tabular}{|c|c|c|c|c|c|c|c|c|c|}
\hline $\begin{array}{c}\text { Section } \\
2 \\
\end{array}$ & & Base & $\begin{array}{l}\text { Lift 1- } \\
\text { Pass } 8 \\
\end{array}$ & $\begin{array}{c}\text { Lift } 2 \\
\text { Pass } 8 \\
\end{array}$ & $\begin{array}{c}\text { Lift } 3 \\
\text { Pass } 1 \\
\end{array}$ & $\begin{array}{c}\text { Lift } 3 \\
\text { Pass } 2 \\
\end{array}$ & $\begin{array}{c}\text { Lift } 3 \\
\text { Pass } 4 \\
\end{array}$ & $\begin{array}{c}\text { Lift } 3 \\
\text { Pass } 8 \\
\end{array}$ & \begin{tabular}{|c|} 
Lift 3 \\
Pass 8W \\
\end{tabular} \\
\hline \multirow{3}{*}{ NDG } & Calculated $\gamma_{\mathrm{d}}\left(\mathrm{lb} / \mathrm{ft}^{3}\right)$ & 113.31 & \#DIV/0! & 121.84 & 120.98 & 120.12 & 125.18 & 123.08 & 124.84 \\
\hline & $\begin{array}{l}\text { Device moisture } \\
\text { content (wt\%) }\end{array}$ & 8.95 & \#DIV/O! & 8.50 & 6.75 & 6.75 & 6.50 & 6.25 & 6.85 \\
\hline & \begin{tabular}{|c|}
$\begin{array}{c}\text { Lab moisture content } \\
(\mathrm{wt} \%)\end{array}$ \\
\end{tabular} & 9.50 & 0.00 & 10.77 & 7.47 & 10.39 & 8.16 & 7.77 & 8.44 \\
\hline \multirow[b]{2}{*}{ DCP } & Blows/150mm & 0 & 0 & 10.77 & 12.00 & 9.00 & 9.00 & 11.00 & 14 \\
\hline & \begin{tabular}{|c|}
$\begin{array}{c}\text { Lab moisture content } \\
\text { (wt\%) }\end{array}$ \\
\end{tabular} & 9.50 & 0.00 & 10.77 & 7.47 & 10.39 & 8.16 & 7.77 & 8.44 \\
\hline \multirow{2}{*}{ ss } & Calculated $\gamma_{\mathrm{d}}\left(\mathrm{lb} / \mathrm{ft}^{3}\right)$ & & & & 132.73 & 133.65 & 134.10 & 124.98 & \\
\hline & \begin{tabular}{|c|} 
Lab moisture content \\
$(\mathrm{w} \%)$
\end{tabular} & & & & 7.44 & 6.67 & 5.43 & 7.08 & \\
\hline \multirow{2}{*}{ Clegg } & Impact Value & & & & 9.10 & 9.70 & 12.30 & 11.00 & 9.3 \\
\hline & \begin{tabular}{|c|}
$\begin{array}{c}\text { Lab moisture content } \\
(\mathrm{w} \%)\end{array}$ \\
\end{tabular} & & & & 7.82 & 8.11 & 6.39 & 6.79 & 4.61 \\
\hline \multirow[b]{2}{*}{ WB } & Calculated $\gamma_{\mathrm{d}}\left(\mathrm{lb} / \mathrm{ft}^{3}\right)$ & & & & 132.91 & 130.22 & 126.83 & 119.11 & \\
\hline & \begin{tabular}{|c|}
$\begin{array}{c}\text { Lab moisture content } \\
\text { (wt } \%)\end{array}$ \\
\end{tabular} & & & & 6.88 & 7.83 & 6.42 & 6.84 & \\
\hline \multirow[b]{2}{*}{ SC } & Calculated $\gamma_{\mathrm{d}}\left(\mathrm{lb} / \mathrm{ft}^{3}\right)$ & & & & 129.35 & 133.00 & 134.50 & 130.41 & \\
\hline & \begin{tabular}{|c|} 
Lab moisture content \\
$(\mathrm{wt} \%)$
\end{tabular} & & & & 8.20 & 7.83 & 7.24 & 7.31 & \\
\hline \multirow{3}{*}{ GG } & Modulus (ksi) -Avg & & & & 57.38 & 4.84 & 10.13 & 10.25 & 5.43 \\
\hline & $\begin{array}{c}\text { Stiffness (kip/in.) - } \\
\text { Avg } \\
\end{array}$ & & & & 12.66 & 21.94 & 45.95 & 46.48 & 24.65 \\
\hline & \begin{tabular}{|c|}
$\begin{array}{c}\text { Lab moisture content } \\
(\mathrm{wt} \%)\end{array}$ \\
\end{tabular} & & & & 7.74 & 7.87 & 6.88 & 6.95 & 7.10 \\
\hline \multirow{3}{*}{ SDG } & Calculated $\gamma_{\mathrm{d}}\left(\mathrm{lb} / \mathrm{ft}^{3}\right)$ & & 0.00 & 0.00 & 113.31 & 110.99 & 109.53 & 108.50 & 107.67 \\
\hline & $\begin{array}{l}\text { Device moisture } \\
\text { content (wt \%) }\end{array}$ & & 0 & 8.63 & 1.20 & 0.40 & 0.20 & -0.30 & -0.60 \\
\hline & \begin{tabular}{|c|}
$\begin{array}{c}\text { Lab moisture content } \\
\text { (wt\%) }\end{array}$ \\
\end{tabular} & & 0 & 0.00 & 7.35 & 7.89 & 8.80 & 8.59 & 8.21 \\
\hline \multirow{3}{*}{ MDI } & Calculated $\gamma_{\mathrm{d}}\left(\mathrm{lb} / \mathrm{ft}^{3}\right)$ & & & & 103.80 & 120.09 & 109.69 & 111.08 & 118.35 \\
\hline & $\begin{array}{l}\text { Device moisture } \\
\text { content (wt\%) }\end{array}$ & & & & 0.10 & 8.90 & 2.10 & 2.70 & 7.20 \\
\hline & \begin{tabular}{|c|}
$\begin{array}{c}\text { Lab moisture content } \\
(\mathrm{wt} \%)\end{array}$ \\
\end{tabular} & & & & 10.13 & 9.30 & 8.36 & 8.05 & 6.52 \\
\hline \multirow{3}{*}{ EDG } & Calculated $\gamma_{\mathrm{d}}\left(\mathrm{b} / \mathrm{ft}^{3}\right)$ & & & & 119.26 & 119.84 & 121.83 & 120.08 & 117.22 \\
\hline & $\begin{array}{c}\text { Device moisture } \\
\text { content (wt } \%)\end{array}$ & & & & 7.30 & 7.20 & 7.40 & 7.50 & 7.20 \\
\hline & \begin{tabular}{|c|} 
Lab moisture content \\
$(\mathrm{wt} \%)$
\end{tabular} & & & & 10.33 & 8.73 & 6.86 & 7.77 & 7.41 \\
\hline \multirow{3}{*}{ ZFW } & s (mm) & & & & 3.60 & 3.71 & 4.30 & 5.01 & 3.85 \\
\hline & $\mathrm{E}\left(\mathrm{MN} / \mathrm{m}^{2}\right)$ & & & & 8.30 & 8.10 & 7.00 & 6.00 & 7.80 \\
\hline & \begin{tabular}{|c|} 
Lab moisture content \\
$(\mathrm{wt} \%)$
\end{tabular} & & & & 6.63 & 7.27 & 9.02 & 7.72 & 7.92 \\
\hline \multirow{3}{*}{ DFW } & Defl (um) -Avg & & & & 2102.00 & 2219.33 & 2038.33 & 2051.33 & 2065.00 \\
\hline & Emod (Mpa)- Avg & & & & 11.67 & 10.33 & 11.00 & 11.00 & 10.67 \\
\hline & \begin{tabular}{|c|} 
Lab moisture content \\
(wt $\%)$
\end{tabular} & & & & 8.54 & 8.89 & 8.21 & 7.57 & 8.06 \\
\hline
\end{tabular}


SM Soil - Test Item 4

\begin{tabular}{|c|c|c|c|c|c|c|c|c|c|}
\hline $\begin{array}{c}\text { Section } \\
3\end{array}$ & & Base & $\begin{array}{l}\text { Lift 1- } \\
\text { Pass } 8\end{array}$ & $\begin{array}{c}\text { Lift } 2 \\
\text { Pass } 8\end{array}$ & $\begin{array}{l}\text { Lift } 3 \\
\text { Pass } 1\end{array}$ & $\begin{array}{l}\text { Lift } 3 \\
\text { Pass } 2\end{array}$ & $\begin{array}{l}\text { Lift } 3 \\
\text { Pass } 4\end{array}$ & $\begin{array}{l}\text { Lift } 3 \\
\text { Pass } 8\end{array}$ & \begin{tabular}{|c|} 
Lift 3 \\
Pass $8 \mathrm{~W}$ \\
\end{tabular} \\
\hline \multirow{3}{*}{ NDG } & Calculated $\gamma_{\mathrm{d}}\left(\mathrm{lb} / \mathrm{ft}^{3}\right)$ & 112.56 & & 121.80 & 127.26 & 123.82 & 126.91 & 125.90 & \\
\hline & $\begin{array}{l}\text { Device moisture } \\
\text { content (wt\%) }\end{array}$ & 13.20 & & 9.75 & 8.95 & 9.05 & 8.05 & 7.75 & \\
\hline & \begin{tabular}{|c|}
$\begin{array}{c}\text { Lab moisture content } \\
(\mathrm{wt} \%)\end{array}$ \\
\end{tabular} & 12.71 & & 10.80 & 8.38 & 9.42 & 8.30 & 8.93 & \\
\hline \multirow[b]{2}{*}{ DCP } & Blows/150mm & 0 & & 10.8 & 15.00 & 8.00 & 6.00 & 8.00 & \\
\hline & \begin{tabular}{|c|}
$\begin{array}{c}\text { Lab moisture content } \\
\text { (wt\%) }\end{array}$ \\
\end{tabular} & 12.71 & & 10.80 & 8.38 & 9.42 & 8.30 & 8.93 & \\
\hline \multirow{2}{*}{ ss } & Calculated $\gamma_{\mathrm{d}}\left(\mathrm{lb} / \mathrm{ft}^{3}\right)$ & & & & 129.38 & 135.51 & 127.63 & 132.75 & \\
\hline & \begin{tabular}{|c|} 
Lab moisture content \\
$(\mathrm{w} \%)$
\end{tabular} & & & & 9.59 & 10.73 & 8.38 & 7.49 & \\
\hline \multirow{2}{*}{ Clegg } & Impact Value & & & & 9.10 & 5.30 & 7.20 & 8.30 & \\
\hline & \begin{tabular}{|c|}
$\begin{array}{c}\text { Lab moisture content } \\
\text { (wt\%) }\end{array}$ \\
\end{tabular} & & & & 9.68 & 9.01 & 9.87 & 6.60 & \\
\hline \multirow[b]{2}{*}{ WB } & Calculated $\gamma_{\mathrm{d}}\left(\mathrm{lb} / \mathrm{ft}^{3}\right)$ & & & & 118.25 & 115.69 & 120.80 & 110.47 & \\
\hline & \begin{tabular}{|c|}
$\begin{array}{c}\text { Lab moisture content } \\
\text { (wt } \%)\end{array}$ \\
\end{tabular} & & & & 9.46 & 8.65 & 7.18 & 7.91 & \\
\hline \multirow[b]{2}{*}{ SC } & Calculated $\gamma_{\mathrm{d}}\left(\mathrm{lb} / \mathrm{ft}^{3}\right)$ & & & & 130.34 & 132.82 & 128.96 & 125.39 & \\
\hline & \begin{tabular}{|c|} 
Lab moisture content \\
$(\mathrm{wt} \%)$
\end{tabular} & & & & 8.98 & 8.65 & 7.95 & 8.41 & \\
\hline \multirow{3}{*}{ GG } & Modulus (ksi) -Avg & & & & 24.44 & 2.93 & 2.42 & 2.95 & \\
\hline & $\begin{array}{c}\text { Stiffness (kip/in.) - } \\
\text { Avg } \\
\end{array}$ & & & & 5.23 & 13.30 & 10.98 & 13.42 & \\
\hline & \begin{tabular}{|c|}
$\begin{array}{c}\text { Lab moisture content } \\
(\mathrm{wt} \%)\end{array}$ \\
\end{tabular} & & & & 9.14 & 9.93 & 8.27 & 6.35 & \\
\hline \multirow{3}{*}{ SDG } & Calculated $\gamma_{\mathrm{d}}\left(\mathrm{lb} / \mathrm{ft}^{3}\right)$ & & & 0.00 & 115.62 & 109.67 & 110.94 & 110.05 & \\
\hline & $\begin{array}{l}\text { Device moisture } \\
\text { content (wt \%) }\end{array}$ & & & 9.15 & 2.50 & 1.50 & 1.00 & 0.40 & \\
\hline & \begin{tabular}{|c|}
$\begin{array}{c}\text { Lab moisture content } \\
\text { (wt\%) }\end{array}$ \\
\end{tabular} & & & 0.00 & 8.89 & 10.98 & 9.14 & 8.75 & \\
\hline \multirow{3}{*}{ MDI } & Calculated $\gamma_{\mathrm{d}}\left(\mathrm{lb} / \mathrm{ft}^{3}\right)$ & & & & 105.32 & 108.38 & 104.19 & 111.16 & \\
\hline & $\begin{array}{l}\text { Device moisture } \\
\text { content (wt\%) }\end{array}$ & & & & 1.60 & 1.90 & 0.10 & 2.40 & \\
\hline & \begin{tabular}{|c|}
$\begin{array}{c}\text { Lab moisture content } \\
(\mathrm{wt} \%)\end{array}$ \\
\end{tabular} & & & & 11.42 & 9.23 & 10.26 & 7.52 & \\
\hline \multirow{3}{*}{ EDG } & Calculated $\gamma_{\mathrm{d}}\left(\mathrm{b} / \mathrm{ft}^{3}\right)$ & & & & 121.68 & 117.49 & 121.31 & 118.61 & \\
\hline & $\begin{array}{c}\text { Device moisture } \\
\text { content (wt\%) }\end{array}$ & & & & 8.50 & 7.30 & 7.40 & 7.60 & \\
\hline & \begin{tabular}{|c|} 
Lab moisture content \\
$(\mathrm{wt} \%)$
\end{tabular} & & & & 10.99 & 11.13 & 6.90 & 9.46 & \\
\hline \multirow{3}{*}{ ZFW } & s (mm) & & & & 5.24 & 6.64 & 5.91 & 6.11 & \\
\hline & $\mathrm{E}\left(\mathrm{MN} / \mathrm{m}^{2}\right)$ & & & & 5.70 & 4.50 & 5.10 & 4.90 & \\
\hline & \begin{tabular}{|c|} 
Lab moisture content \\
$(\mathrm{wt} \%)$
\end{tabular} & & & & 10.58 & 9.86 & 8.99 & 8.78 & \\
\hline \multirow{3}{*}{ DFW } & Defl (um) -Avg & & & & 1982.00 & 2217.00 & 2116.33 & 2258.00 & \\
\hline & Emod (Mpa)- Avg & & & & 12.00 & 8.00 & 10.33 & 9.33 & \\
\hline & \begin{tabular}{|c|} 
Lab moisture content \\
(wt $\%)$
\end{tabular} & & & & 10.19 & 9.28 & 8.86 & 9.77 & \\
\hline
\end{tabular}


SM Soil - Test Item 4

\begin{tabular}{|c|c|c|c|c|c|c|c|c|c|}
\hline $\begin{array}{c}\text { Section } \\
4\end{array}$ & & Base & $\begin{array}{l}\text { Lift 1- } \\
\text { Pass } 8\end{array}$ & $\begin{array}{c}\text { Lift } 2 \\
\text { Pass } 8\end{array}$ & $\begin{array}{l}\text { Lift } 3 \\
\text { Pass } 1\end{array}$ & $\begin{array}{l}\text { Lift } 3 \\
\text { Pass } 2\end{array}$ & $\begin{array}{l}\text { Lift } 3 \\
\text { Pass } 4\end{array}$ & $\begin{array}{l}\text { Lift } 3 \\
\text { Pass } 8\end{array}$ & \begin{tabular}{|c|} 
Lift 3 \\
Pass $8 \mathrm{~W}$
\end{tabular} \\
\hline \multirow{3}{*}{ NDG } & Calculated $\gamma_{\mathrm{d}}\left(\mathrm{lb} / \mathrm{ft}^{3}\right)$ & 122.08 & & 117.85 & 124.95 & 126.97 & 123.43 & 121.51 & \\
\hline & $\begin{array}{l}\text { Device moisture } \\
\text { content (wt } \%)\end{array}$ & 9.70 & & 9.20 & 8.10 & 8.85 & 7.25 & 7.60 & \\
\hline & \begin{tabular}{|c|} 
Lab moisture content \\
(wt $\%)$
\end{tabular} & 10.66 & & 15.00 & 8.96 & 7.15 & 10.59 & 7.77 & \\
\hline \multirow[b]{2}{*}{ DCP } & "Blows/150mm & 0 & & 15 & 7.00 & 7.00 & 6.00 & 7.00 & \\
\hline & \begin{tabular}{|c|}
$\begin{array}{c}\text { Lab moisture content } \\
\text { (wt\%) }\end{array}$ \\
\end{tabular} & 10.66 & & 15.00 & 8.96 & 7.15 & 10.59 & 7.77 & \\
\hline \multirow[b]{2}{*}{ SS } & Calculated $\gamma_{\mathrm{d}}\left(\mathrm{lb} / \mathrm{ft}^{3}\right)$ & & & & 137.61 & 126.71 & 141.25 & 123.70 & \\
\hline & \begin{tabular}{|c|} 
Lab moisture content \\
(wt $\%)$
\end{tabular} & & & & 5.75 & 7.78 & 6.52 & 7.13 & \\
\hline \multirow[b]{2}{*}{ Clegg } & Impact Value & & & & 26.60 & 7.00 & 9.30 & 6.90 & \\
\hline & \begin{tabular}{|c|} 
Lab moisture content \\
(wt $\%)$
\end{tabular} & & & & 9.16 & 11.06 & 8.25 & 7.74 & \\
\hline \multirow[b]{2}{*}{ WB } & Calculated $\gamma_{\mathrm{d}}\left(\mathrm{lb} / \mathrm{ft}^{3}\right)$ & & & & 123.46 & 112.58 & 117.00 & 116.88 & \\
\hline & \begin{tabular}{|c|}
$\begin{array}{c}\text { Lab moisture content } \\
\text { (wt } \%)\end{array}$ \\
\end{tabular} & & & & 9.11 & 8.23 & 7.96 & 6.81 & \\
\hline \multirow[b]{2}{*}{ SC } & Calculated $\gamma_{\mathrm{d}}\left(\mathrm{lb} / \mathrm{ft}^{3}\right)$ & & & & 137.50 & 134.08 & 133.66 & 133.47 & \\
\hline & \begin{tabular}{|c|} 
Lab moisture content \\
(wt $\%)$
\end{tabular} & & & & 7.84 & 8.23 & 8.14 & 6.27 & \\
\hline \multirow{3}{*}{ GG } & Modulus (ksi) -Avg & & & & 24.11 & \#DIV/0! & 3.72 & 2.15 & \\
\hline & $\begin{array}{c}\text { Stiffness (kip/in.) - } \\
\text { Avg }\end{array}$ & & & & 5.32 & \#DIV/0! & 16.86 & 9.73 & \\
\hline & \begin{tabular}{|c|}
$\begin{array}{c}\text { Lab moisture content } \\
\text { (wt\%) }\end{array}$ \\
\end{tabular} & & & & 7.29 & 6.92 & 7.66 & 7.90 & \\
\hline \multirow{3}{*}{ SDG } & Calculated $\gamma_{\mathrm{d}}\left(\mathrm{lb} / \mathrm{ft}^{3}\right)$ & & & 0.00 & 113.87 & 108.86 & 111.12 & 108.95 & \\
\hline & $\begin{array}{c}\text { Device moisture } \\
\text { content (wt\%) }\end{array}$ & & & 13.23 & 2.40 & 1.60 & 1.00 & -0.10 & \\
\hline & \begin{tabular}{|c|} 
Lab moisture content \\
(wt $\%)$
\end{tabular} & & & 0.00 & 10.27 & 12.14 & 9.07 & 8.75 & \\
\hline \multirow{3}{*}{ MDI } & Calculated $\gamma_{\mathrm{d}}\left(\mathrm{b} / \mathrm{ft}^{3}\right)$ & & & & 108.99 & 103.04 & 105.82 & 106.20 & \\
\hline & $\begin{array}{l}\text { Device moisture } \\
\text { content (wt\%) }\end{array}$ & & & & 3.00 & 0.10 & 0.80 & 0.10 & \\
\hline & \begin{tabular}{|c|}
$\begin{array}{c}\text { Lab moisture content } \\
\text { (wt\%) }\end{array}$ \\
\end{tabular} & & & & 10.22 & 9.61 & 9.79 & 8.05 & \\
\hline \multirow{3}{*}{ EDG } & Calculated $\gamma_{\mathrm{d}}\left(\mathrm{lb} / \mathrm{ft}^{3}\right)$ & & & & 121.96 & 120.88 & 120.67 & 119.37 & \\
\hline & $\begin{array}{c}\text { Device moisture } \\
\text { content (wt } \%)\end{array}$ & & & & 8.50 & 8.40 & 7.70 & 7.70 & \\
\hline & \begin{tabular}{|c|} 
Lab moisture content \\
(wt $\%)$
\end{tabular} & & & & 10.78 & 11.25 & 8.58 & 9.36 & \\
\hline \multirow{3}{*}{ ZFW } & $\mathrm{s}(\mathrm{mm})$ & & & & 4.71 & 6.24 & 6.01 & 5.83 & \\
\hline & $\mathrm{E}\left(\mathrm{MN} / \mathrm{m}^{2}\right)$ & & & & 6.40 & 4.80 & 5.00 & 5.20 & \\
\hline & \begin{tabular}{|c|} 
Lab moisture content \\
(wt $\%)$
\end{tabular} & & & & 9.89 & 9.60 & 8.94 & 7.60 & \\
\hline \multirow{3}{*}{ DFW } & Defl (um) - Avg & & & & 2107.67 & 2127.00 & 2107.00 & 2247.33 & \\
\hline & Emod (Mpa)- Avg & & & & 10.33 & 7.67 & 7.67 & 7.67 & \\
\hline & $\begin{array}{c}\text { Lab moisture content } \\
\text { (wt } \%)\end{array}$ & & & & 11.38 & 8.90 & 7.18 & 9.32 & \\
\hline
\end{tabular}


SP-SM Soil - Test Item 5

\begin{tabular}{|c|c|c|c|c|c|c|c|c|c|}
\hline Section 1 & & Base & $\begin{array}{l}\text { Lift 1- } \\
\text { Pass } 8\end{array}$ & $\begin{array}{c}\text { Lift } 2 \\
\text { Pass } 8\end{array}$ & $\begin{array}{c}\text { Lift } 3 \\
\text { Pass } 1\end{array}$ & $\begin{array}{c}\text { Lift } 3 \\
\text { Pass } 2\end{array}$ & $\begin{array}{c}\text { Lift } 3 \\
\text { Pass } 4\end{array}$ & $\begin{array}{c}\text { Lift } 3 \\
\text { Pass } 8\end{array}$ & $\begin{array}{c}\text { Lift } 3 \\
\text { Pass 8W }\end{array}$ \\
\hline \multirow{3}{*}{ NDG } & Calculated $\gamma_{\mathrm{d}}\left(\mathrm{lb} / \mathrm{ft}^{3}\right)$ & 107.04 & 130.75 & 127.62 & 119.36 & 116.44 & 121.11 & 120.84 & 119.80 \\
\hline & $\begin{array}{l}\text { Device moisture } \\
\text { content (wt } \%)\end{array}$ & 10.45 & 8.15 & 7.75 & 6.35 & 6.75 & 6.40 & 5.55 & 8.20 \\
\hline & \begin{tabular}{|c} 
Lab moisture content \\
$(\mathrm{wt} \%)$
\end{tabular} & 11.43 & 6.04 & 6.16 & 5.38 & 7.07 & 6.48 & 4.89 & 8.93 \\
\hline \multirow[b]{2}{*}{ DCP } & Blows/150mm & 0 & 12 & 11 & 5.00 & 5.00 & 8.00 & 10.00 & 11 \\
\hline & \begin{tabular}{|c} 
Lab moisture content \\
$(\mathrm{wt} \%)$
\end{tabular} & 11.43 & 6.04 & 6.16 & 5.38 & 7.07 & 6.48 & 4.89 & 8.93 \\
\hline \multirow{2}{*}{ SS } & Calculated $\gamma_{\mathrm{d}}\left(\mathrm{lb} / \mathrm{ft}^{3}\right)$ & & & & 133.94 & 133.05 & 99.88 & 127.25 & \\
\hline & $\begin{array}{c}\text { Lab moisture content } \\
\text { (wt } \%)\end{array}$ & & & & 5.94 & 6.63 & 4.79 & 6.02 & \\
\hline \multirow{2}{*}{ Clegg } & Impact Value & & & & 6.00 & 7.20 & 7.90 & 12.00 & 10.9 \\
\hline & \begin{tabular}{|c|} 
Lab moisture content \\
(wt $\%)$
\end{tabular} & & & & 5.54 & 6.74 & 6.01 & 4.23 & 7.67 \\
\hline \multirow[b]{2}{*}{ WB } & Calculated $\gamma_{\mathrm{d}}\left(\mathrm{lb} / \mathrm{ft}^{3}\right)$ & & & & 122.12 & 124.21 & 125.06 & 122.20 & \\
\hline & $\begin{array}{c}\text { Lab moisture content } \\
\text { (wt } \%)\end{array}$ & & & & 6.01 & 6.36 & 5.17 & 5.95 & \\
\hline \multirow[b]{2}{*}{ SC } & Calculated $\gamma_{\mathrm{d}}\left(\mathrm{lb} / \mathrm{ft}^{3}\right)$ & & & & 127.90 & 127.34 & 124.47 & 128.41 & \\
\hline & \begin{tabular}{|c|}
$\begin{array}{c}\text { Lab moisture content } \\
\text { (wt } \%)\end{array}$ \\
\end{tabular} & & & & 7.08 & 6.36 & 5.51 & 6.05 & \\
\hline \multirow{3}{*}{ GG } & Modulus (ksi) -Avg & & & & 16.00 & 14.38 & & 12.53 & 9.90 \\
\hline & $\begin{array}{c}\text { Stiffness (kip/in.) - } \\
\text { Avg }\end{array}$ & & & & 72.85 & 65.22 & & 108.73 & 85.90 \\
\hline & \begin{tabular}{|c|}
$\begin{array}{c}\text { Lab moisture content } \\
(\mathrm{wt} \%)\end{array}$ \\
\end{tabular} & & & & 6.25 & 7.00 & & 4.98 & 6.88 \\
\hline \multirow{3}{*}{ SDG } & Calculated $\gamma_{\mathrm{d}}\left(\mathrm{lb} / \mathrm{ft}^{3}\right)$ & & 100.57 & 97.68 & 101.41 & 99.37 & 97.57 & 98.52 & 95.66 \\
\hline & $\begin{array}{c}\text { Device moisture } \\
\text { content (wt\%) }\end{array}$ & & 20.1 & 19.40 & 19.90 & 19.60 & 19.30 & 19.30 & 19.50 \\
\hline & \begin{tabular}{|c|}
$\begin{array}{c}\text { Lab moisture content } \\
\text { (wt } \%)\end{array}$ \\
\end{tabular} & & 8.9 & 6.88 & 6.96 & 6.52 & 6.99 & 5.36 & 8.02 \\
\hline \multirow{3}{*}{ MDI } & Calculated $\gamma_{\mathrm{d}}\left(\mathrm{lb} / \mathrm{ft}^{3}\right)$ & & & & 110.27 & 98.74 & 99.81 & 100.39 & 108.08 \\
\hline & $\begin{array}{c}\text { Device moisture } \\
\text { content (wt\%) }\end{array}$ & & & & 4.40 & 0.10 & 0.10 & 0.10 & 4.10 \\
\hline & $\begin{array}{c}\begin{array}{c}\text { Lab moisture content } \\
(\mathrm{wt} \%)\end{array} \\
\end{array}$ & & & & 6.79 & 5.60 & 6.02 & 6.18 & 8.02 \\
\hline \multirow{3}{*}{ EDG } & Calculated $\gamma_{\mathrm{d}}\left(\mathrm{lb} / \mathrm{ft}^{3}\right)$ & & & & 115.79 & 121.14 & 113.82 & 120.53 & 115.75 \\
\hline & $\begin{array}{c}\text { Device moisture } \\
\text { content (wt } \%)\end{array}$ & & & & 8.50 & 7.70 & 9.00 & 8.50 & 8.10 \\
\hline & \begin{tabular}{|c|}
$\begin{array}{c}\text { Lab moisture content } \\
\text { (wt } \%)\end{array}$ \\
\end{tabular} & & & & 7.88 & 7.10 & 6.01 & 4.57 & 9.07 \\
\hline \multirow{3}{*}{ ZFW } & $\mathrm{s}(\mathrm{mm})$ & & & & 2.31 & 1.74 & 1.95 & 1.54 & 1.21 \\
\hline & $\mathrm{E}\left(\mathrm{MN} / \mathrm{m}^{2}\right)$ & & & & 13.00 & 17.30 & 15.40 & 19.50 & 24.80 \\
\hline & \begin{tabular}{|c|}
$\begin{array}{c}\text { Lab moisture content } \\
\text { (wt } \%)\end{array}$ \\
\end{tabular} & & & & 7.43 & 5.90 & 5.32 & 5.23 & 7.57 \\
\hline \multirow{3}{*}{ DFW } & Defl (um) -Avg & & & & 1989.67 & 1747.33 & 2180.33 & 2194.67 & 1749.00 \\
\hline & Emod (Mpa)- Avg & & & & 12.33 & 15.00 & 11.33 & 11.33 & 15.33 \\
\hline & $\begin{array}{c}\text { Lab moisture content } \\
\text { (wt } \%)\end{array}$ & & & & 6.71 & 6.26 & 6.33 & 4.57 & 8.88 \\
\hline
\end{tabular}


SP-SM Soil - Test Item 5

\begin{tabular}{|c|c|c|c|c|c|c|c|c|c|}
\hline $\begin{array}{c}\text { Section } \\
2\end{array}$ & & Base & $\begin{array}{l}\text { Lift 1- } \\
\text { Pass } 8\end{array}$ & $\begin{array}{c}\text { Lift } 2 \\
\text { Pass } 8\end{array}$ & $\begin{array}{l}\text { Lift } 3 \\
\text { Pass } 1\end{array}$ & $\begin{array}{l}\text { Lift } 3 \\
\text { Pass } 2\end{array}$ & $\begin{array}{l}\text { Lift } 3 \\
\text { Pass } 4\end{array}$ & $\begin{array}{c}\text { Lift } 3 \\
\text { Pass } 8\end{array}$ & \begin{tabular}{|c|} 
Lift 3 \\
Pass 8W
\end{tabular} \\
\hline \multirow{3}{*}{ NDG } & Calculated $\gamma_{\mathrm{d}}\left(\mathrm{lb} / \mathrm{ft}^{3}\right)$ & 105.78 & 128.28 & 129.10 & 116.57 & 116.67 & 121.46 & 118.28 & 120.53 \\
\hline & $\begin{array}{l}\text { Device moisture } \\
\text { content (wt\%) }\end{array}$ & 11.60 & 9.10 & 8.50 & 6.30 & 6.45 & 5.80 & 6.00 & 8.00 \\
\hline & $\begin{array}{c}\text { Lab moisture content } \\
\text { (wt } \%)\end{array}$ & 14.00 & 8.37 & 6.11 & 7.74 & 6.55 & 5.77 & 5.94 & 8.45 \\
\hline \multirow[b]{2}{*}{ DCP } & Blows/150mm & 0 & 11 & 12 & 4.00 & 5.00 & 7.00 & 8.00 & 9 \\
\hline & \begin{tabular}{|c|} 
Lab moisture content \\
(wt $\%)$
\end{tabular} & 14.00 & 8.37 & 6.11 & 7.74 & 6.55 & 5.77 & 5.94 & 8.45 \\
\hline \multirow{2}{*}{ SS } & Calculated $\gamma_{\mathrm{d}}\left(\mathrm{lb} / \mathrm{ft}^{3}\right)$ & & & & 132.88 & 129.72 & 128.66 & 123.72 & \\
\hline & \begin{tabular}{|c|} 
Lab moisture content \\
(wt $\%)$
\end{tabular} & & & & 5.89 & 6.88 & 5.19 & 7.05 & \\
\hline \multirow{2}{*}{ Clegg } & Impact Value & & & & 6.00 & 7.70 & 6.80 & 10.90 & 7.2 \\
\hline & \begin{tabular}{|c|}
$\begin{array}{c}\text { Lab moisture content } \\
\text { (wt } \%)\end{array}$ \\
\end{tabular} & & & & 6.91 & 6.09 & 6.40 & 4.03 & 8.69 \\
\hline \multirow[b]{2}{*}{ WB } & Calculated $\gamma_{\mathrm{d}}\left(\mathrm{lb} / \mathrm{ft}^{3}\right)$ & & & & 122.11 & 124.10 & 121.58 & 122.92 & \\
\hline & \begin{tabular}{|c|}
$\begin{array}{c}\text { Lab moisture content } \\
\text { (wt } \%)\end{array}$ \\
\end{tabular} & & & & 6.29 & 6.41 & 5.41 & 5.67 & \\
\hline \multirow[b]{2}{*}{ sc } & Calculated $\gamma_{\mathrm{d}}\left(\mathrm{lb} / \mathrm{ft}^{3}\right)$ & & & & $\begin{array}{l}131.49 \\
\end{array}$ & 128.00 & 131.56 & 130.04 & \\
\hline & \begin{tabular}{|c|} 
Lab moisture content \\
(wt $\%)$
\end{tabular} & & & & 5.90 & 6.41 & 5.98 & 5.36 & \\
\hline \multirow{3}{*}{ GG } & Modulus (ksi) -Avg & & & & 15.75 & 13.94 & & 13.29 & 9.11 \\
\hline & $\begin{array}{c}\text { Stiffness (kip/in.) - } \\
\text { Avg }\end{array}$ & & & & 71.43 & 63.22 & & 115.32 & 79.07 \\
\hline & \begin{tabular}{|c|} 
Lab moisture content \\
(wt $\%)$
\end{tabular} & & & & 7.26 & 7.35 & & 4.85 & 8.62 \\
\hline \multirow{3}{*}{ SDG } & Calculated $\gamma_{\mathrm{d}}\left(\mathrm{lb} / \mathrm{ft}^{3}\right)$ & & 102.04 & 98.93 & 101.06 & 100.14 & 98.83 & 98.27 & 98.96 \\
\hline & $\begin{array}{c}\text { Device moisture } \\
\text { content (wt\%) }\end{array}$ & & 20.3 & 19.60 & 19.90 & 19.70 & 19.30 & 19.40 & 19.80 \\
\hline & \begin{tabular}{|c|}
$\begin{array}{c}\text { Lab moisture content } \\
\text { (wt\%) }\end{array}$ \\
\end{tabular} & & 8.73 & 6.93 & 7.62 & 6.32 & 5.24 & 6.32 & 7.17 \\
\hline \multirow{3}{*}{ MDI } & Calculated $\gamma_{\mathrm{d}}\left(\mathrm{lb} / \mathrm{ft}^{3}\right)$ & & & & 97.61 & 100.91 & 100.81 & 101.79 & 107.04 \\
\hline & $\begin{array}{l}\text { Device moisture } \\
\text { content (wt\%) }\end{array}$ & & & & 0.10 & 0.90 & 0.20 & 0.10 & 3.80 \\
\hline & \begin{tabular}{|c|} 
Lab moisture content \\
(wt $\%)$
\end{tabular} & & & & 6.68 & 6.48 & 5.87 & 4.24 & 8.36 \\
\hline \multirow{3}{*}{ EDG } & Calculated $\gamma_{\mathrm{d}}\left(\mathrm{lb} / \mathrm{ft}^{3}\right)$ & & & & 1116.24 & 120.22 & 1115.16 & 119.07 & 115.61 \\
\hline & $\begin{array}{l}\text { Device moisture } \\
\text { content (wt } \% \text { ) }\end{array}$ & & & & 8.60 & 7.80 & 8.50 & 8.60 & 8.10 \\
\hline & \begin{tabular}{|c|} 
Lab moisture content \\
(wt $\%)$
\end{tabular} & & & & 6.86 & 7.38 & 5.53 & 5.20 & 8.97 \\
\hline \multirow{3}{*}{ ZFW } & s $(\mathrm{mm})$ & & & & 2.04 & 2.49 & 2.48 & 1.63 & 1.59 \\
\hline & $\mathrm{E}\left(\mathrm{MN} / \mathrm{m}^{2}\right)$ & & & & 14.70 & 12.10 & 12.10 & 18.40 & 18.80 \\
\hline & \begin{tabular}{|c|} 
Lab moisture content \\
(wt $\%)$
\end{tabular} & & & & 6.56 & 7.29 & 5.90 & 7.63 & 7.87 \\
\hline \multirow{3}{*}{ DFW } & Defl (um) - Avg & & & & 2270.00 & 2106.67 & 2148.00 & 2303.33 & 1455.00 \\
\hline & Emod (Mpa)- Avg & & & & 11.00 & 12.00 & 11.33 & 10.67 & 18.33 \\
\hline & \begin{tabular}{|c|} 
Lab moisture content \\
(wt $\%)$
\end{tabular} & & & & 5.41 & 7.02 & 6.17 & 5.67 & 8.07 \\
\hline
\end{tabular}


SP-SM Soil - Test Item 5

\begin{tabular}{|c|c|c|c|c|c|c|c|c|c|}
\hline $\begin{array}{c}\text { Section } \\
3 \\
\end{array}$ & & Base & $\begin{array}{c}\text { Lift 1- } \\
\text { Pass } 8 \\
\end{array}$ & $\begin{array}{c}\text { Lift } 2 \\
\text { Pass } 8 \\
\end{array}$ & $\begin{array}{c}\text { Lift } 3 \\
\text { Pass } 1 \\
\end{array}$ & $\begin{array}{c}\text { Lift } 3 \\
\text { Pass } 2 \\
\end{array}$ & $\begin{array}{c}\text { Lift } 3 \\
\text { Pass } 4 \\
\end{array}$ & $\begin{array}{c}\text { Lift } 3 \\
\text { Pass } 8 \\
\end{array}$ & \begin{tabular}{|c|} 
Lift 3 \\
Pass 8W \\
\end{tabular} \\
\hline \multirow{3}{*}{ NDG } & Calculated $\gamma_{\mathrm{d}}\left(\mathrm{lb} / \mathrm{ft}^{3}\right)$ & 112.81 & 129.08 & 128.73 & 116.13 & 117.06 & 118.45 & 117.16 & 121.09 \\
\hline & $\begin{array}{c}\text { Device moisture } \\
\text { content (wt\%) }\end{array}$ & 10.15 & 8.85 & 8.10 & 6.65 & 5.80 & 5.30 & 6.05 & 7.90 \\
\hline & $\begin{array}{c}\text { Lab moisture content } \\
\text { (wt } \%)\end{array}$ & 10.36 & 8.03 & 6.31 & 6.91 & 6.76 & 5.84 & 6.16 & 7.85 \\
\hline \multirow[b]{2}{*}{ DCP } & Blows/150mm & 0 & 15 & 9 & 4.00 & 6.00 & 6.00 & 8.00 & 10 \\
\hline & \begin{tabular}{|c|}
$\begin{array}{c}\text { Lab moisture content } \\
\text { (wt } \%)\end{array}$ \\
\end{tabular} & 10.36 & 8.03 & 6.31 & 6.91 & 6.76 & 5.84 & 6.16 & 7.85 \\
\hline \multirow{2}{*}{ SS } & Calculated $\gamma_{\mathrm{d}}\left(\mathrm{lb} / \mathrm{ft}^{3}\right)$ & & & & 127.38 & 133.73 & 126.72 & 124.65 & \\
\hline & \begin{tabular}{|c|}
$\begin{array}{c}\text { Lab moisture content } \\
\text { (wt } \%)\end{array}$ \\
\end{tabular} & & & & 6.13 & 5.22 & 5.15 & 5.64 & \\
\hline \multirow{2}{*}{ Clegg } & Impact Value & & & & 7.60 & 8.80 & 6.20 & 10.50 & 7.9 \\
\hline & \begin{tabular}{|c|}
$\begin{array}{c}\text { Lab moisture content } \\
\text { (wt } \%)\end{array}$ \\
\end{tabular} & & & & 7.01 & 6.59 & 6.20 & 4.78 & 8.7 \\
\hline \multirow[b]{2}{*}{ WB } & Calculated $\gamma_{\mathrm{d}}\left(\mathrm{lb} / \mathrm{ft}^{3}\right)$ & & & & 111.55 & 115.34 & 119.95 & 112.45 & \\
\hline & $\begin{array}{c}\begin{array}{c}\text { Lab moisture content } \\
\text { (wt } \%)\end{array} \\
\end{array}$ & & & & 6.53 & 6.50 & 5.74 & 5.78 & \\
\hline \multirow[b]{2}{*}{ SC } & Calculated $\gamma_{\mathrm{d}}\left(\mathrm{lb} / \mathrm{ft}^{3}\right)$ & & & & 130.25 & 128.47 & 129.24 & 131.03 & \\
\hline & \begin{tabular}{|c|}
$\begin{array}{c}\text { Lab moisture content } \\
\text { (wt } \%)\end{array}$ \\
\end{tabular} & & & & 6.73 & 6.50 & 5.75 & 5.60 & \\
\hline \multirow{3}{*}{ GG } & Modulus (ksi) -Avg & & & & 12.50 & 13.26 & \#DIV/O! & 12.98 & 10.17 \\
\hline & $\begin{array}{c}\text { Stiffness (kip/in.) - } \\
\text { Avg }\end{array}$ & & & & 56.67 & 60.12 & \#DIV/O! & 112.59 & 88.24 \\
\hline & $\begin{array}{c}\text { Lab moisture content } \\
(\mathrm{wt} \%)\end{array}$ & & & & 7.40 & 0.00 & 0.00 & 7.63 & 8.30 \\
\hline \multirow{3}{*}{ SDG } & Calculated $\gamma_{\mathrm{d}}\left(\mathrm{lb} / \mathrm{ft}^{3}\right)$ & & 100.33 & 99.18 & 101.88 & 99.04 & 96.89 & 98.09 & 97.74 \\
\hline & $\begin{array}{c}\text { Device moisture } \\
\text { content (wt } \%)\end{array}$ & & 20.1 & 19.50 & 19.90 & 18.70 & 19.30 & 19.20 & 19.80 \\
\hline & \begin{tabular}{|c|}
$\begin{array}{c}\text { Lab moisture content } \\
\text { (wt } \%)\end{array}$ \\
\end{tabular} & & 9.45 & 6.70 & 6.53 & 7.96 & 6.93 & 5.14 & 7.97 \\
\hline \multirow{3}{*}{ MDI } & Calculated $\gamma_{\mathrm{d}}\left(\mathrm{lb} / \mathrm{ft}^{3}\right)$ & & & & 96.84 & 98.93 & 99.24 & 100.63 & 108.80 \\
\hline & $\begin{array}{c}\text { Device moisture } \\
\text { content (wt\%) }\end{array}$ & & & & 0.10 & 0.30 & 0.10 & 0.20 & 4.90 \\
\hline & \begin{tabular}{|c|}
$\begin{array}{c}\text { Lab moisture content } \\
(\mathrm{wt} \%)\end{array}$ \\
\end{tabular} & & & & 7.51 & 7.80 & 5.93 & 6.13 & 9.11 \\
\hline \multirow{3}{*}{ EDG } & Calculated $\gamma_{\mathrm{d}}\left(\mathrm{lb} / \mathrm{ft}^{3}\right)$ & & & & 120.98 & 119.38 & 119.18 & 118.38 & 117.03 \\
\hline & $\begin{array}{c}\text { Device moisture } \\
\text { content (wt } \%)\end{array}$ & & & & 7.90 & 8.00 & 8.10 & 8.50 & 7.80 \\
\hline & \begin{tabular}{|c|}
$\begin{array}{c}\text { Lab moisture content } \\
\text { (wt } \%)\end{array}$ \\
\end{tabular} & & & & 7.01 & 7.10 & 5.49 & 5.67 & 9.21 \\
\hline \multirow{3}{*}{ ZFW } & $\mathrm{s}(\mathrm{mm})$ & & & & 2.37 & 2.45 & 3.01 & 2.22 & 1.58 \\
\hline & $\mathrm{E}\left(\mathrm{MN} / \mathrm{m}^{2}\right)$ & & & & 12.70 & 12.30 & 10.00 & 13.50 & 19.00 \\
\hline & \begin{tabular}{|c|}
$\begin{array}{c}\text { Lab moisture content } \\
\text { (wt } \%)\end{array}$ \\
\end{tabular} & & & & 6.55 & 6.32 & 5.20 & 5.96 & 7.88 \\
\hline \multirow{3}{*}{ DFW } & Defl (um) -Avg & & & & 2305.33 & 1975.33 & 2238.33 & 2348.00 & 1984.33 \\
\hline & Emod (Mpa)- Avg & & & & 10.33 & 13.00 & 9.67 & 10.33 & 12.67 \\
\hline & \begin{tabular}{|c|}
$\begin{array}{c}\text { Lab moisture content } \\
(\mathrm{wt} \%)\end{array}$ \\
\end{tabular} & & & & 6.41 & 6.40 & 6.35 & 6.52 & 8.61 \\
\hline
\end{tabular}


SP-SM Soil - Test Item 5

\begin{tabular}{|c|c|c|c|c|c|c|c|c|c|}
\hline $\begin{array}{c}\text { Section } \\
4 \\
\end{array}$ & & Base & $\begin{array}{c}\text { Lift 1- } \\
\text { Pass } 8 \\
\end{array}$ & $\begin{array}{c}\text { Lift } 2 \\
\text { Pass } 8 \\
\end{array}$ & $\begin{array}{c}\text { Lift } 3 \\
\text { Pass } 1 \\
\end{array}$ & $\begin{array}{c}\text { Lift } 3 \\
\text { Pass } 2 \\
\end{array}$ & $\begin{array}{c}\text { Lift } 3 \\
\text { Pass } 4 \\
\end{array}$ & $\begin{array}{c}\text { Lift } 3 \\
\text { Pass } 8 \\
\end{array}$ & $\begin{array}{c}\text { Lift } 3 \\
\text { Pass 8W } \\
\end{array}$ \\
\hline \multirow{3}{*}{ NDG } & Calculated $\gamma_{\mathrm{d}}\left(\mathrm{lb} / \mathrm{ft}^{3}\right)$ & 113.07 & 70.37 & 126.09 & 117.25 & 64.24 & 120.35 & 114.67 & 117.68 \\
\hline & $\begin{array}{c}\text { Device moisture } \\
\text { content (wt\%) }\end{array}$ & 10.85 & 8.70 & 8.80 & 6.25 & 6.50 & 5.85 & 6.25 & 7.70 \\
\hline & $\begin{array}{c}\text { Lab moisture content } \\
(\mathrm{wt} \%)\end{array}$ & 12.28 & 49.48 & 6.77 & 7.13 & 49.18 & 5.53 & 7.34 & 8.53 \\
\hline \multirow[b]{2}{*}{ DCP } & Blows/150mm & 0 & 14 & 10 & 4.00 & 6.00 & 10.00 & 7.00 & 9 \\
\hline & \begin{tabular}{|c|}
$\begin{array}{c}\text { Lab moisture content } \\
(\mathrm{wt} \%)\end{array}$ \\
\end{tabular} & 12.28 & 49.48 & 6.77 & 7.13 & 49.18 & 5.53 & 7.34 & 8.53 \\
\hline \multirow[b]{2}{*}{ SS } & Calculated $\gamma_{\mathrm{d}}\left(\mathrm{lb} / \mathrm{ft}^{3}\right)$ & & & & 120.03 & 152.66 & 126.55 & 133.20 & \\
\hline & $\begin{array}{c}\begin{array}{c}\text { Lab moisture content } \\
(\mathrm{wt} \%)\end{array} \\
\end{array}$ & & & & 6.81 & 6.46 & 5.98 & 5.60 & \\
\hline \multirow[b]{2}{*}{ Clegg } & Impact Value & & & & 6.70 & 7.30 & 6.00 & 10.80 & 5.2 \\
\hline & \begin{tabular}{|c|} 
Lab moisture content \\
$(\mathrm{wt} \%)$
\end{tabular} & & & & 6.85 & 6.23 & 5.89 & 4.34 & 6.64 \\
\hline \multirow[b]{2}{*}{ WB } & Calculated $\gamma_{\mathrm{d}}\left(\mathrm{lb} / \mathrm{ft}^{3}\right)$ & & & & 125.82 & 132.67 & 119.90 & 126.92 & \\
\hline & \begin{tabular}{|c|}
$\begin{array}{c}\text { Lab moisture content } \\
(\mathrm{wt} \%)\end{array}$ \\
\end{tabular} & & & & 6.75 & 5.98 & 4.95 & 5.93 & \\
\hline \multirow[b]{2}{*}{ SC } & Calculated $\gamma_{\mathrm{d}}\left(\mathrm{lb} / \mathrm{ft}^{3}\right)$ & & & & 125.71 & 134.15 & 127.24 & 126.26 & \\
\hline & \begin{tabular}{|c|}
$\begin{array}{c}\text { Lab moisture content } \\
(\mathrm{wt} \%)\end{array}$ \\
\end{tabular} & & & & 6.83 & 5.98 & 5.08 & 5.49 & \\
\hline \multirow{3}{*}{ GG } & Modulus (ksi) -Avg & & & & 12.90 & & & 12.16 & 9.36 \\
\hline & $\begin{array}{c}\text { Stiffness (kip/in.) - } \\
\text { Avg }\end{array}$ & & & & 58.51 & & & 105.53 & 81.21 \\
\hline & \begin{tabular}{|c|}
$\begin{array}{c}\text { Lab moisture content } \\
(\mathrm{wt} \%)\end{array}$ \\
\end{tabular} & & & & 7.16 & & & 7.38 & 9.25 \\
\hline \multirow{3}{*}{ SDG } & Calculated $\gamma_{\mathrm{d}}\left(\mathrm{lb} / \mathrm{ft}^{3}\right)$ & & 103.29 & 97.19 & 103.33 & 98.80 & 96.84 & 99.29 & 102.09 \\
\hline & $\begin{array}{c}\text { Device moisture } \\
\text { content (wt\%) }\end{array}$ & & 20.1 & 19.40 & 19.90 & 19.70 & 19.30 & 19.40 & 20.20 \\
\hline & \begin{tabular}{|c|}
$\begin{array}{c}\text { Lab moisture content } \\
\text { (wt } \%)\end{array}$ \\
\end{tabular} & & 7.03 & 7.96 & 4.68 & 7.66 & 6.88 & 5.17 & 7.36 \\
\hline \multirow{3}{*}{ MDI } & Calculated $\gamma_{\mathrm{d}}\left(\mathrm{lb} / \mathrm{ft}^{3}\right)$ & & & & 108.26 & 99.37 & 99.49 & 99.33 & 109.09 \\
\hline & $\begin{array}{c}\text { Device moisture } \\
\text { content (wt \%) }\end{array}$ & & & & 3.60 & 0.10 & 0.10 & 0.10 & 4.30 \\
\hline & \begin{tabular}{|c|}
$\begin{array}{c}\text { Lab moisture content } \\
\text { (wt } \%)\end{array}$ \\
\end{tabular} & & & & 6.75 & 6.43 & 6.58 & 5.49 & 7.63 \\
\hline \multirow{3}{*}{ EDG } & Calculated $\gamma_{\mathrm{d}}\left(\mathrm{lb} / \mathrm{ft}^{3}\right)$ & & & & 122.49 & 119.46 & 121.33 & 118.79 & 116.68 \\
\hline & $\begin{array}{c}\text { Device moisture } \\
\text { content (wt \%) }\end{array}$ & & & & 7.70 & 8.00 & 7.70 & 8.50 & 8.00 \\
\hline & \begin{tabular}{|c|}
$\begin{array}{c}\text { Lab moisture content } \\
(\mathrm{wt} \%)\end{array}$ \\
\end{tabular} & & & & 6.57 & 6.16 & 5.65 & 5.87 & 8.84 \\
\hline \multirow{3}{*}{ ZFW } & $\mathrm{s}(\mathrm{mm})$ & & & & 2.88 & 2.89 & 3.17 & 2.17 & 1.80 \\
\hline & $\mathrm{E}\left(\mathrm{MN} / \mathrm{m}^{2}\right)$ & & & & 10.40 & 10.40 & 9.50 & 13.90 & 16.70 \\
\hline & \begin{tabular}{|c|}
$\begin{array}{c}\text { Lab moisture content } \\
(\mathrm{wt} \%)\end{array}$ \\
\end{tabular} & & & & 7.52 & 6.67 & 7.07 & 5.41 & 8.62 \\
\hline \multirow{3}{*}{ DFW } & Defl (um) -Avg & & & & 2284.00 & 2032.00 & 2285.67 & 2207.67 & 1756.00 \\
\hline & Emod (Mpa)- Avg & & & & 10.67 & 11.33 & 11.33 & 11.67 & 15.00 \\
\hline & \begin{tabular}{|c|}
$\begin{array}{c}\text { Lab moisture content } \\
(\mathrm{wt} \%)\end{array}$ \\
\end{tabular} & & & & 7.85 & 7.08 & 5.95 & 5.33 & 9.07 \\
\hline
\end{tabular}


CH Soil - Test Item 6

\begin{tabular}{|c|c|c|c|c|c|c|c|c|c|}
\hline $\begin{array}{c}\text { Section } \\
1\end{array}$ & & Base & $\begin{array}{l}\text { Lift 1- } \\
\text { Pass } 8\end{array}$ & $\begin{array}{c}\text { Lift } 2 \\
\text { Pass } 8\end{array}$ & $\begin{array}{c}\text { Lift } 3 \\
\text { Pass } 1 \\
\end{array}$ & $\begin{array}{l}\text { Lift } 3 \\
\text { Pass } 2\end{array}$ & $\begin{array}{l}\text { Lift } 3 \\
\text { Pass } 4\end{array}$ & $\begin{array}{l}\text { Lift } 3 \\
\text { Pass } 8\end{array}$ & \begin{tabular}{|c|} 
Lift 3 \\
Pass $8 \mathrm{~W}$ \\
\end{tabular} \\
\hline \multirow{3}{*}{ NDG } & Calculated $\gamma_{\mathrm{d}}\left(\mathrm{lb} / \mathrm{ft}^{3}\right)$ & 113.99 & 83.44 & 80.99 & 81.93 & 78.11 & 85.12 & 80.70 & \\
\hline & $\begin{array}{l}\text { Device moisture } \\
\text { content (wt\%) }\end{array}$ & 12.25 & 28.75 & 27.85 & 27.55 & 26.40 & 26.50 & 27.10 & \\
\hline & \begin{tabular}{|c|c|}
$\begin{array}{c}\text { Lab moisture content } \\
(\mathrm{wt} \%)\end{array}$ \\
\end{tabular} & 11.26 & 29.20 & 29.91 & 26.95 & 26.69 & 26.24 & 26.77 & \\
\hline \multirow[b]{2}{*}{ DCP } & Blows/150mm & 0 & 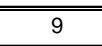 & 29.91 & 8.00 & 10.00 & 12.00 & 10.00 & \\
\hline & \begin{tabular}{|c|}
$\begin{array}{c}\text { Lab moisture content } \\
\text { (wt\%) }\end{array}$ \\
\end{tabular} & 11.26 & 29.20 & 29.91 & 26.95 & 26.69 & 26.24 & 26.77 & \\
\hline \multirow{2}{*}{ ss } & Calculated $\gamma_{\mathrm{d}}\left(\mathrm{lb} / \mathrm{ft}^{3}\right)$ & & & & 109.29 & 98.51 & 81.63 & 97.73 & \\
\hline & \begin{tabular}{|c|} 
Lab moisture content \\
$(\mathrm{wt} \%)$
\end{tabular} & & & & 25.55 & 26.04 & 35.62 & 26.24 & \\
\hline \multirow{2}{*}{ Clegg } & Impact Value & & & \multicolumn{2}{|c|}{ Data Not Collected - Mis } & 13.30 & 13.30 & 9.90 & \\
\hline & \begin{tabular}{|c|}
$\begin{array}{c}\text { Lab moisture content } \\
\text { (wt\%) }\end{array}$ \\
\end{tabular} & & & & 0.00 & 25.80 & 24.56 & 25.57 & \\
\hline \multirow[b]{2}{*}{ WB } & Calculated $\gamma_{\mathrm{d}}\left(\mathrm{lb} / \mathrm{ft}^{3}\right)$ & & & & 82.78 & 82.31 & 83.29 & 81.93 & \\
\hline & \begin{tabular}{|c|}
$\begin{array}{c}\text { Lab moisture content } \\
\text { (wt } \%)\end{array}$ \\
\end{tabular} & & & & 26.05 & 28.16 & 27.35 & 26.72 & \\
\hline \multirow[b]{2}{*}{ SC } & Calculated $\gamma_{\mathrm{d}}\left(\mathrm{lb} / \mathrm{ft}^{3}\right)$ & & & & 88.14 & 78.45 & 89.31 & 86.03 & \\
\hline & \begin{tabular}{|c|} 
Lab moisture content \\
$(\mathrm{wt} \%)$
\end{tabular} & & & & 26.49 & 28.16 & 26.43 & 27.83 & \\
\hline \multirow{3}{*}{ GG } & Modulus (ksi) -Avg & & & & 54.48 & 61.36 & $\begin{array}{ll}66.89 \\
\end{array}$ & 53.86 & \\
\hline & $\begin{array}{c}\text { Stiffness (kip/in.) - } \\
\text { Avg }\end{array}$ & & & & 12.01 & 13.53 & 14.75 & 11.87 & \\
\hline & \begin{tabular}{|c|}
$\begin{array}{c}\text { Lab moisture content } \\
(\mathrm{wt} \%)\end{array}$ \\
\end{tabular} & & & & 25.86 & 29.07 & 26.10 & 29.48 & \\
\hline \multirow{3}{*}{ SDG } & Calculated $\gamma_{\mathrm{d}}\left(\mathrm{lb} / \mathrm{ft}^{3}\right)$ & & 86.40 & 0.00 & 91.17 & 86.56 & 96.21 & 86.71 & \\
\hline & $\begin{array}{l}\text { Device moisture } \\
\text { content (wt \%) }\end{array}$ & & 22.3 & 26.45 & 22.30 & 21.80 & 22.30 & 22.40 & \\
\hline & \begin{tabular}{|c|}
$\begin{array}{c}\text { Lab moisture content } \\
\text { (wt\%) }\end{array}$ \\
\end{tabular} & & 34.15 & 0.00 & 30.46 & 29.91 & 26.39 & 34.06 & \\
\hline \multirow{3}{*}{ MDI } & Calculated $\gamma_{\mathrm{d}}\left(\mathrm{lb} / \mathrm{ft}^{3}\right)$ & & & & 85.64 & 83.42 & 88.63 & 86.70 & \\
\hline & $\begin{array}{l}\text { Device moisture } \\
\text { content (wt\%) }\end{array}$ & & & & 28.80 & 19.60 & 28.10 & 22.20 & \\
\hline & \begin{tabular}{|c|}
$\begin{array}{c}\text { Lab moisture content } \\
(\mathrm{wt} \%)\end{array}$ \\
\end{tabular} & & & & 27.85 & 28.82 & 25.27 & 26.34 & \\
\hline \multirow{3}{*}{ EDG } & Calculated $\gamma_{\mathrm{d}}\left(\mathrm{b} / \mathrm{ft}^{3}\right)$ & & & & 85.25 & 81.76 & 85.58 & 85.19 & \\
\hline & $\begin{array}{c}\text { Device moisture } \\
\text { content (wt\%) }\end{array}$ & & & & 28.70 & 25.70 & 26.10 & 36.30 & \\
\hline & \begin{tabular}{|c|} 
Lab moisture content \\
$(\mathrm{wt} \%)$
\end{tabular} & & & & 27.69 & 28.22 & 26.10 & 25.47 & \\
\hline \multirow{3}{*}{ ZFW } & s (mm) & & & & 1.67 & 1.35 & 0.64 & 1.63 & \\
\hline & $\mathrm{E}\left(\mathrm{MN} / \mathrm{m}^{2}\right)$ & & & & 18.00 & 22.30 & 47.00 & 18.40 & \\
\hline & \begin{tabular}{|c|}
$\begin{array}{c}\text { Lab moisture content } \\
(\mathrm{wt} \%)\end{array}$ \\
\end{tabular} & & & & 32.56 & 25.33 & 27.34 & 25.89 & \\
\hline \multirow{3}{*}{ DFW } & Defl (um) -Avg & & & & (506.33 & 536.00 & 340.67 & (513.33 & \\
\hline & Emod (Mpa)- Avg & & & & 53.00 & 49.67 & 78.00 & 52.33 & \\
\hline & \begin{tabular}{|c|} 
Lab moisture content \\
(wt $\%)$
\end{tabular} & & & & 29.27 & 28.61 & 25.91 & 30.67 & \\
\hline
\end{tabular}


CH Soil - Test Item 6

\begin{tabular}{|c|c|c|c|c|c|c|c|c|c|}
\hline $\begin{array}{c}\text { Section } \\
2 \\
\end{array}$ & & Base & $\begin{array}{l}\text { Lift 1- } \\
\text { Pass } 8\end{array}$ & $\begin{array}{c}\text { Lift } 2 \\
\text { Pass } 8\end{array}$ & $\begin{array}{l}\text { Lift } 3 \\
\text { Pass } 1\end{array}$ & $\begin{array}{l}\text { Lift } 3 \\
\text { Pass } 2\end{array}$ & $\begin{array}{l}\text { Lift } 3 \\
\text { Pass } 4\end{array}$ & $\begin{array}{l}\text { Lift } 3 \\
\text { Pass } 8\end{array}$ & \begin{tabular}{|c|} 
Lift 3 \\
Pass $8 \mathrm{~W}$
\end{tabular} \\
\hline \multirow{3}{*}{ NDG } & Calculated $\gamma_{\mathrm{d}}\left(\mathrm{lb} / \mathrm{ft}^{3}\right)$ & 108.68 & 82.07 & 80.66 & 81.30 & 78.83 & 85.94 & 82.91 & \\
\hline & $\begin{array}{l}\text { Device moisture } \\
\text { content (wt\%) }\end{array}$ & 9.55 & 27.95 & 27.10 & 28.55 & 27.25 & 25.70 & 26.80 & \\
\hline & \begin{tabular}{|c|c|}
$\begin{array}{c}\text { Lab moisture content } \\
(\mathrm{wt} \%)\end{array}$ \\
\end{tabular} & 10.81 & 25.93 & 28.30 & 26.79 & 27.65 & 25.98 & 27.56 & \\
\hline \multirow[b]{2}{*}{ DCP } & Blows/150mm & 0 & 10 & 28.3 & 10.00 & 8.00 & 10.00 & 6.00 & \\
\hline & \begin{tabular}{|c|}
$\begin{array}{c}\text { Lab moisture content } \\
\text { (wt\%) }\end{array}$ \\
\end{tabular} & 10.81 & 25.93 & 28.30 & 26.79 & 27.65 & 25.98 & 27.56 & \\
\hline \multirow{2}{*}{ ss } & Calculated $\gamma_{\mathrm{d}}\left(\mathrm{lb} / \mathrm{ft}^{3}\right)$ & & & & 97.26 & 97.72 & 103.14 & 98.97 & \\
\hline & \begin{tabular}{|c|} 
Lab moisture content \\
$(\mathrm{w} \%)$
\end{tabular} & & & & 30.38 & 25.29 & 27.06 & 25.81 & \\
\hline \multirow{2}{*}{ Clegg } & Impact Value & & & & 0.00 & 13.80 & 4.00 & 8.50 & \\
\hline & \begin{tabular}{|c|}
$\begin{array}{c}\text { Lab moisture content } \\
\text { (wt\%) }\end{array}$ \\
\end{tabular} & & & & 0.00 & 26.39 & 30.03 & 28.21 & \\
\hline \multirow[b]{2}{*}{ WB } & Calculated $\gamma_{\mathrm{d}}\left(\mathrm{lb} / \mathrm{ft}^{3}\right)$ & & & & 81.95 & 82.97 & 123.86 & 85.86 & \\
\hline & \begin{tabular}{|c|}
$\begin{array}{c}\text { Lab moisture content } \\
\text { (wt } \%)\end{array}$ \\
\end{tabular} & & & & 26.79 & 25.04 & 29.43 & 25.44 & \\
\hline \multirow[b]{2}{*}{ SC } & Calculated $\gamma_{\mathrm{d}}\left(\mathrm{lb} / \mathrm{ft}^{3}\right)$ & & & & 87.61 & 87.85 & 79.83 & 91.69 & \\
\hline & \begin{tabular}{|c|} 
Lab moisture content \\
$(\mathrm{wt} \%)$
\end{tabular} & & & & 24.80 & 25.04 & 28.15 & 24.72 & \\
\hline \multirow{3}{*}{ GG } & Modulus (ksi) -Avg & & & & 488.72 & 55.99 & $4 \quad 46.69$ & 78.42 & \\
\hline & $\begin{array}{c}\text { Stiffness (kip/in.) - } \\
\text { Avg } \\
\end{array}$ & & & & 10.74 & 12.23 & 10.29 & 17.29 & \\
\hline & \begin{tabular}{|c|}
$\begin{array}{c}\text { Lab moisture content } \\
(\mathrm{wt} \%)\end{array}$ \\
\end{tabular} & & & & 29.88 & 27.53 & 34.93 & 25.97 & \\
\hline \multirow{3}{*}{ SDG } & Calculated $\gamma_{\mathrm{d}}\left(\mathrm{lb} / \mathrm{ft}^{3}\right)$ & & 94.76 & 0.00 & 91.43 & 87.33 & 92.21 & 77.31 & \\
\hline & $\begin{array}{l}\text { Device moisture } \\
\text { content (wt \%) }\end{array}$ & & 22 & 26.58 & 22.00 & 21.30 & 21.90 & 21.50 & \\
\hline & \begin{tabular}{|c|}
$\begin{array}{c}\text { Lab moisture content } \\
\text { (wt\%) }\end{array}$ \\
\end{tabular} & & 25.03 & 0.00 & 27.84 & 27.04 & 26.64 & 36.00 & \\
\hline \multirow{3}{*}{ MDI } & Calculated $\gamma_{\mathrm{d}}\left(\mathrm{lb} / \mathrm{ft}^{3}\right)$ & & & & 88.39 & 88.98 & 76.52 & 84.50 & \\
\hline & $\begin{array}{l}\text { Device moisture } \\
\text { content (wt\%) }\end{array}$ & & & & 0.10 & 31.40 & 24.70 & 29.40 & \\
\hline & \begin{tabular}{|c|}
$\begin{array}{c}\text { Lab moisture content } \\
(\mathrm{wt} \%)\end{array}$ \\
\end{tabular} & & & & 26.22 & 25.23 & 35.21 & 28.87 & \\
\hline \multirow{3}{*}{ EDG } & Calculated $\gamma_{\mathrm{d}}\left(\mathrm{b} / \mathrm{ft}^{3}\right)$ & & & & 86.33 & 83.31 & 84.26 & 86.61 & \\
\hline & $\begin{array}{c}\text { Device moisture } \\
\text { content (wt\%) }\end{array}$ & & & & 25.50 & 23.10 & 34.00 & 31.70 & \\
\hline & \begin{tabular}{|c|} 
Lab moisture content \\
$(\mathrm{wt} \%)$
\end{tabular} & & & & 26.59 & 26.34 & 27.17 & 23.56 & \\
\hline \multirow{3}{*}{ ZFW } & s (mm) & & & & 0.75 & 1.62 & 0.97 & 0.61 & \\
\hline & $\mathrm{E}\left(\mathrm{MN} / \mathrm{m}^{2}\right)$ & & & & 40.30 & 18.50 & 30.90 & 49.60 & \\
\hline & \begin{tabular}{|c|} 
Lab moisture content \\
$(\mathrm{wt} \%)$
\end{tabular} & & & & 26.86 & 33.10 & 26.57 & 26.04 & \\
\hline \multirow{3}{*}{ DFW } & Defl (um) -Avg & & & & 847.67 & 811.00 & 430.67 & 651.67 & \\
\hline & Emod (Mpa)- Avg & & & & 31.33 & 33.33 & 61.33 & 40.33 & \\
\hline & \begin{tabular}{|c|} 
Lab moisture content \\
(wt $\%)$
\end{tabular} & & & & 28.12 & 32.27 & 25.38 & 31.06 & \\
\hline
\end{tabular}


CH Soil - Test Item 6

\begin{tabular}{|c|c|c|c|c|c|c|c|c|c|}
\hline $\begin{array}{c}\text { Section } \\
4\end{array}$ & & Base & $\begin{array}{c}\text { Lift } 1 \\
\text { Pass } 8\end{array}$ & $\begin{array}{c}\text { Lift } 2 \\
\text { Pass } 8\end{array}$ & $\begin{array}{c}\text { Lift } 3 \\
\text { Pass } 1\end{array}$ & $\begin{array}{c}\text { Lift } 3 \\
\text { Pass } 2\end{array}$ & $\begin{array}{c}\text { Lift } 3 \\
\text { Pass } 4\end{array}$ & $\begin{array}{c}\text { Lift } 3 \\
\text { Pass } 8\end{array}$ & $\begin{array}{c}\text { Lift } 3 \\
\text { Pass } 8 W\end{array}$ \\
\hline \multirow{3}{*}{ NDG } & Calculated $\gamma_{\mathrm{d}}\left(\mathrm{lb} / \mathrm{ft}^{3}\right)$ & 100.05 & 85.22 & 83.47 & 80.03 & 74.51 & 85.56 & 78.20 & \\
\hline & $\begin{array}{c}\text { Device moisture } \\
\text { content (wt\%) }\end{array}$ & 17.25 & 26.30 & 27.05 & 27.10 & 26.40 & 25.15 & 25.95 & \\
\hline & \begin{tabular}{|c|}
$\begin{array}{c}\text { Lab moisture content } \\
(\mathrm{wt} \%)\end{array}$ \\
\end{tabular} & 20.02 & 27.47 & 26.78 & 27.01 & 34.61 & 27.34 & 32.59 & \\
\hline \multirow[b]{2}{*}{ DCP } & Blows/150mm & 0 & 7 & 26.78 & 8.00 & 8.00 & 8.00 & 9.00 & \\
\hline & \begin{tabular}{|c|}
$\begin{array}{c}\text { Lab moisture content } \\
(\mathrm{wt} \%)\end{array}$ \\
\end{tabular} & 20.02 & 27.47 & 26.78 & 27.01 & 34.61 & 27.34 & 32.59 & \\
\hline \multirow{2}{*}{ SS } & Calculated $\gamma_{\mathrm{d}}\left(\mathrm{lb} / \mathrm{ft}^{3}\right)$ & & & & 96.44 & 109.60 & 100.38 & 103.41 & \\
\hline & \begin{tabular}{|c|}
$\begin{array}{c}\text { Lab moisture content } \\
\text { (wt } \%)\end{array}$ \\
\end{tabular} & & & & 25.18 & 26.49 & 26.94 & 24.74 & \\
\hline \multirow{2}{*}{ Clegg } & Impact Value & & & & 0.00 & 9.90 & 9.30 & 4.90 & \\
\hline & $\begin{array}{c}\begin{array}{c}\text { Lab moisture content } \\
\text { (wt } \%)\end{array} \\
\end{array}$ & & & & 0.00 & 26.68 & 28.62 & 31.30 & \\
\hline \multirow[b]{2}{*}{ WB } & Calculated $\gamma_{\mathrm{d}}\left(\mathrm{lb} / \mathrm{ft}^{3}\right)$ & & & & 77.40 & 80.67 & \#VALUE! & 79.44 & \\
\hline & \begin{tabular}{|c|}
$\begin{array}{c}\text { Lab moisture content } \\
\text { (wt } \%)\end{array}$ \\
\end{tabular} & & & & 28.07 & 24.56 & 15.50 & 27.90 & \\
\hline \multirow[b]{2}{*}{ SC } & Calculated $\gamma_{\mathrm{d}}\left(\mathrm{lb} / \mathrm{ft}^{3}\right)$ & & & & 109.35 & 91.06 & 91.45 & 89.77 & \\
\hline & \begin{tabular}{|c|}
$\begin{array}{c}\text { Lab moisture content } \\
(\mathrm{wt} \%)\end{array}$ \\
\end{tabular} & & & & 7.64 & 24.56 & 25.71 & 26.30 & \\
\hline \multirow{3}{*}{ GG } & Modulus (ksi) -Avg & & & & 55.47 & 51.73 & 48.15 & 49.57 & \\
\hline & $\begin{array}{c}\text { Stiffness (kip/in.) - } \\
\text { Avg } \\
\end{array}$ & & & & 12.23 & 11.41 & 10.61 & 10.93 & \\
\hline & \begin{tabular}{|c|}
$\begin{array}{c}\text { Lab moisture content } \\
(\mathrm{wt} \%)\end{array}$ \\
\end{tabular} & & & & 27.78 & 25.67 & 32.84 & 27.86 & \\
\hline \multirow{3}{*}{ SDG } & Calculated $\gamma_{\mathrm{d}}\left(\mathrm{lb} / \mathrm{ft}^{3}\right)$ & & 91.91 & 0.00 & 89.62 & 93.14 & 86.05 & 88.16 & \\
\hline & $\begin{array}{c}\text { Device moisture } \\
\text { content (wt\%) }\end{array}$ & & 22.2 & 27.80 & 21.80 & 22.10 & 21.10 & 22.10 & \\
\hline & \begin{tabular}{|c|}
$\begin{array}{c}\text { Lab moisture content } \\
(\mathrm{wt} \%)\end{array}$ \\
\end{tabular} & & 28.81 & 0.00 & 28.07 & 28.19 & 26.58 & 31.34 & \\
\hline \multirow{3}{*}{ MDI } & Calculated $\gamma_{\mathrm{d}}\left(\mathrm{lb} / \mathrm{ft}^{3}\right)$ & & & & \#VALUE! & 84.92 & 87.42 & 84.63 & \\
\hline & $\begin{array}{c}\text { Device moisture } \\
\text { content (wt } \%)\end{array}$ & & & & 0.00 & 26.60 & 18.60 & 31.70 & \\
\hline & \begin{tabular}{|c|}
$\begin{array}{c}\text { Lab moisture content } \\
(\mathrm{wt} \%)\end{array}$ \\
\end{tabular} & & & & 0.00 & 28.22 & 25.35 & 28.94 & \\
\hline \multirow{3}{*}{ EDG } & Calculated $\gamma_{\mathrm{d}}\left(\mathrm{lb} / \mathrm{ft}^{3}\right)$ & & & & 87.07 & 79.85 & 85.85 & 83.84 & \\
\hline & $\begin{array}{c}\text { Device moisture } \\
\text { content (wt\%) }\end{array}$ & & & & 28.70 & 26.70 & 25.60 & 34.10 & \\
\hline & \begin{tabular}{|c|}
$\begin{array}{c}\text { Lab moisture content } \\
(\mathrm{wt} \%)\end{array}$ \\
\end{tabular} & & & & 25.77 & 27.74 & 25.86 & 26.46 & \\
\hline \multirow{3}{*}{ ZFW } & $\mathrm{s}(\mathrm{mm})$ & & & & 1.28 & 1.13 & 0.68 & 0.58 & \\
\hline & $\mathrm{E}\left(\mathrm{MN} / \mathrm{m}^{2}\right)$ & & & & 23.50 & 26.60 & 44.20 & 51.70 & \\
\hline & \begin{tabular}{|c|}
$\begin{array}{c}\text { Lab moisture content } \\
\text { (wt } \%)\end{array}$ \\
\end{tabular} & & & & 27.54 & 26.78 & 27.77 & 26.68 & \\
\hline \multirow{3}{*}{ DFW } & Defl (um) -Avg & & & & 536.00 & 889.67 & 335.33 & 374.00 & \\
\hline & Emod (Mpa)- Avg & & & & 49.33 & 29.00 & 80.00 & 66.67 & \\
\hline & \begin{tabular}{|c|}
$\begin{array}{c}\text { Lab moisture content } \\
(\mathrm{wt} \%)\end{array}$ \\
\end{tabular} & & & & 27.35 & 31.04 & 29.01 & 26.30 & \\
\hline
\end{tabular}


CH Soil - Test Item 6

\begin{tabular}{|c|c|c|c|c|c|c|c|c|c|}
\hline $\begin{array}{c}\text { Section } \\
4\end{array}$ & & Base & $\begin{array}{c}\text { Lift } 1 \\
\text { Pass } 8\end{array}$ & $\begin{array}{c}\text { Lift } 2 \\
\text { Pass } 8\end{array}$ & $\begin{array}{c}\text { Lift } 3 \\
\text { Pass } 1\end{array}$ & $\begin{array}{c}\text { Lift } 3 \\
\text { Pass } 2\end{array}$ & $\begin{array}{c}\text { Lift } 3 \\
\text { Pass } 4\end{array}$ & $\begin{array}{c}\text { Lift } 3 \\
\text { Pass } 8\end{array}$ & $\begin{array}{c}\text { Lift } 3 \\
\text { Pass 8W }\end{array}$ \\
\hline \multirow{3}{*}{ NDG } & Calculated $\gamma_{\mathrm{d}}\left(\mathrm{lb} / \mathrm{ft}^{3}\right)$ & 113.36 & 86.96 & 84.63 & 81.94 & 83.53 & 86.04 & 88.12 & \\
\hline & $\begin{array}{c}\text { Device moisture } \\
\text { content (wt\%) }\end{array}$ & 11.50 & 26.90 & 25.90 & 27.75 & 26.90 & 26.15 & 25.50 & \\
\hline & \begin{tabular}{|c|} 
Lab moisture content \\
(wt $\%)$
\end{tabular} & 12.97 & 25.16 & 27.17 & 26.94 & 25.88 & 27.33 & 25.10 & \\
\hline \multirow[b]{2}{*}{ DCP } & Blows/150mm & 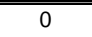 & 11 & 27.17 & 9.00 & 10.00 & 12.00 & 12.00 & \\
\hline & \begin{tabular}{|c|}
$\begin{array}{c}\text { Lab moisture content } \\
(\mathrm{wt} \%)\end{array}$ \\
\end{tabular} & 12.97 & 25.16 & 27.17 & 26.94 & 25.88 & 27.33 & 25.10 & \\
\hline \multirow[b]{2}{*}{ SS } & Calculated $\gamma_{\mathrm{d}}\left(\mathrm{lb} / \mathrm{ft}^{3}\right)$ & & & & 103.23 & 96.72 & 103.47 & 90.94 & \\
\hline & \begin{tabular}{|c} 
Lab moisture content \\
$(\mathrm{wt} \%)$
\end{tabular} & & & & 26.37 & 31.65 & 26.51 & 27.07 & \\
\hline \multirow[b]{2}{*}{ Clegg } & Impact Value & & & & 0.00 & 111.80 & 11.40 & "6.30 & \\
\hline & \begin{tabular}{|c|}
$\begin{array}{c}\text { Lab moisture content } \\
(\mathrm{wt} \%)\end{array}$ \\
\end{tabular} & & & & 0.00 & 26.00 & 26.04 & 29.19 & \\
\hline \multirow[b]{2}{*}{ WB } & Calculated $\gamma_{\mathrm{d}}\left(\mathrm{lb} / \mathrm{ft}^{3}\right)$ & & & & 80.70 & 78.18 & 83.91 & 85.48 & \\
\hline & \begin{tabular}{|c} 
Lab moisture content \\
(wt $\%)$
\end{tabular} & & & & 28.47 & 26.87 & 26.81 & 26.11 & \\
\hline \multirow[b]{2}{*}{ SC } & Calculated $\gamma_{\mathrm{d}}\left(\mathrm{lb} / \mathrm{ft}^{3}\right)$ & & & & 82.67 & 83.51 & 89.62 & 85.28 & \\
\hline & \begin{tabular}{|c|}
$\begin{array}{c}\text { Lab moisture content } \\
(\mathrm{wt} \%)\end{array}$ \\
\end{tabular} & & & & 29.22 & 26.87 & 26.90 & 27.97 & \\
\hline \multirow{3}{*}{ GG } & "Modulus (ksi) -Avg & & & & 68.72 & 53.33 & 68.54 & 59.99 & \\
\hline & $\begin{array}{c}\text { Stiffness (kip/in.) - } \\
\text { Avg }\end{array}$ & & & & 15.15 & 11.76 & 15.11 & 13.23 & \\
\hline & \begin{tabular}{|c|}
$\begin{array}{c}\text { Lab moisture content } \\
(\mathrm{wt} \%)\end{array}$ \\
\end{tabular} & & & & 26.87 & 25.56 & 23.80 & 30.88 & \\
\hline \multirow{3}{*}{ SDG } & Calculated $\gamma_{\mathrm{d}}\left(\mathrm{lb} / \mathrm{ft}^{3}\right)$ & & 94.94 & 0.00 & 91.62 & 92.19 & 99.63 & 94.20 & \\
\hline & $\begin{array}{l}\text { Device moisture } \\
\text { content (wt } \%)\end{array}$ & & 22.5 & 26.76 & 22.20 & 21.80 & 22.50 & 22.20 & \\
\hline & \begin{tabular}{|c|}
$\begin{array}{c}\text { Lab moisture content } \\
(\mathrm{wt} \%)\end{array}$ \\
\end{tabular} & & 28.56 & 0.00 & 29.25 & 25.71 & 25.54 & 27.03 & \\
\hline \multirow{3}{*}{ MDI } & Calculated $\gamma_{\mathrm{d}}\left(\mathrm{lb} / \mathrm{ft}^{3}\right)$ & & & & 0.00 & 86.85 & 85.90 & 119.50 & \\
\hline & $\begin{array}{c}\text { Device moisture } \\
\text { content (wt } \%)\end{array}$ & & & & 0.00 & 25.00 & 15.00 & 34.70 & \\
\hline & \begin{tabular}{|c|}
$\begin{array}{c}\text { Lab moisture content } \\
(\mathrm{wt} \%)\end{array}$ \\
\end{tabular} & & & & 0.00 & 26.46 & 26.20 & 0.00 & \\
\hline \multirow{3}{*}{ EDG } & Calculated $\gamma_{\mathrm{d}}\left(\mathrm{lb} / \mathrm{ft}^{3}\right)$ & & & & 85.44 & 82.22 & 82.56 & 83.41 & \\
\hline & $\begin{array}{c}\text { Device moisture } \\
\text { content (wt } \%)\end{array}$ & & & & 32.40 & 31.80 & 33.00 & 25.50 & \\
\hline & \begin{tabular}{|c|}
$\begin{array}{c}\text { Lab moisture content } \\
(\mathrm{wt} \%)\end{array}$ \\
\end{tabular} & & & & 27.04 & 27.30 & 28.58 & 26.19 & \\
\hline \multirow{3}{*}{ ZFW } & s (mm) & & & & 0.87 & 1.16 & 0.87 & 0.67 & \\
\hline & $\mathrm{E}\left(\mathrm{MN} / \mathrm{m}^{2}\right)$ & & & & 34.40 & 25.80 & 34.70 & 45.10 & \\
\hline & \begin{tabular}{|c|}
$\begin{array}{c}\text { Lab moisture content } \\
\text { (wt } \%)\end{array}$ \\
\end{tabular} & & & & 28.58 & 25.65 & 30.02 & 25.75 & \\
\hline \multirow{3}{*}{ DFW } & Defl (um) -Avg & & & & 745.00 & 574.00 & 436.67 & 472.33 & \\
\hline & Emod (Mpa)- Avg & & & & 35.33 & 46.33 & 61.00 & 56.00 & \\
\hline & \begin{tabular}{|c|}
$\begin{array}{c}\text { Lab moisture content } \\
(\mathrm{wt} \%)\end{array}$ \\
\end{tabular} & & & & 30.18 & 25.82 & 25.55 & 27.38 & \\
\hline
\end{tabular}


GP-GM Soil - Test Item 7

\begin{tabular}{|c|c|c|c|c|c|c|c|c|c|}
\hline $\begin{array}{c}\text { Section } \\
1 \\
\end{array}$ & & Base & $\begin{array}{l}\text { Lift 1- } \\
\text { Pass } 8\end{array}$ & $\begin{array}{c}\text { Lift } 2 \\
\text { Pass } 8\end{array}$ & $\begin{array}{c}\text { Lift } 3 \\
\text { Pass } 1\end{array}$ & $\begin{array}{c}\text { Lift } 3 \\
\text { Pass } 2\end{array}$ & $\begin{array}{c}\text { Lift } 3 \\
\text { Pass } 4\end{array}$ & $\begin{array}{c}\text { Lift } 3 \\
\text { Pass } 8\end{array}$ & $\begin{array}{c}\text { Lift } 3 \\
\text { Pass 8W }\end{array}$ \\
\hline \multirow{3}{*}{ NDG } & Calculated $\gamma_{\mathrm{d}}\left(\mathrm{lb} / \mathrm{ft}^{3}\right)$ & 101.69 & 137.79 & 138.16 & 126.96 & 128.99 & 132.58 & 136.87 & 132.54 \\
\hline & $\begin{array}{l}\text { Device moisture } \\
\text { content (wt } \%)\end{array}$ & 10.45 & 3.55 & 3.50 & 2.80 & 3.30 & 2.55 & 3.30 & 3.20 \\
\hline & \begin{tabular}{|c|} 
Lab moisture content \\
$(\mathrm{wt} \%)$
\end{tabular} & 10.64 & 3.81 & 3.79 & 2.97 & 3.16 & 2.55 & 2.72 & 3.40 \\
\hline \multirow[b]{2}{*}{ DCP } & Blows/150mm & 0 & 16 & ב3.79 & 7.00 & 7.00 & 9.00 & 0.00 & 20 \\
\hline & $\begin{array}{c}\text { Lab moisture content } \\
(\mathrm{wt} \%)\end{array}$ & 10.64 & 3.81 & 3.79 & 2.97 & 3.16 & 2.55 & 2.72 & 3.40 \\
\hline \multirow{2}{*}{ SS } & Calculated $\gamma_{\mathrm{d}}\left(\mathrm{lb} / \mathrm{ft}^{3}\right)$ & & & & 118.04 & 141.65 & 136.55 & 129.53 & \\
\hline & $\begin{array}{c}\text { Lab moisture content } \\
\text { (wt } \%)\end{array}$ & & & & 3.80 & 3.18 & 2.60 & 2.09 & \\
\hline \multirow{2}{*}{ Clegg } & Impact Value & & & & 12.90 & 17.20 & 20.80 & 26.20 & 16 \\
\hline & \begin{tabular}{|c|} 
Lab moisture content \\
$(\mathrm{wt} \%)$
\end{tabular} & & & & 3.49 & 3.05 & 3.47 & 2.71 & 4.69 \\
\hline \multirow[b]{2}{*}{ WB } & Calculated $\gamma_{\mathrm{d}}\left(\mathrm{b} / \mathrm{ft}^{3}\right)$ & & & & 123.45 & 129.73 & 123.56 & 5746.85 & \\
\hline & $\begin{array}{c}\text { Lab moisture content } \\
(\mathrm{wt} \%)\end{array}$ & & & & 3.54 & 3.00 & 2.66 & 2.38 & \\
\hline \multirow[b]{2}{*}{ SC } & Calculated $\gamma_{\mathrm{d}}\left(\mathrm{lb} / \mathrm{ft}^{3}\right)$ & & & & 134.15 & 132.21 & 134.96 & 140.70 & \\
\hline & \begin{tabular}{|c|} 
Lab moisture content \\
$(\mathrm{wt} \%)$
\end{tabular} & & & & 3.07 & 3.00 & 2.91 & 2.83 & \\
\hline \multirow{3}{*}{ GG } & Modulus (ksi) -Avg & & & & 12.19 & 14.96 & 13.30 & 14.29 & 17.07 \\
\hline & $\begin{array}{c}\text { Stiffness (kip/in.) - } \\
\text { Avg }\end{array}$ & & & & 55.26 & 67.85 & 60.30 & 65.43 & 77.40 \\
\hline & $\begin{array}{c}\text { Lab moisture content } \\
(\mathrm{wt} \%)\end{array}$ & & & & 3.85 & 3.26 & 3.14 & 2.89 & 4.00 \\
\hline \multirow{3}{*}{ SDG } & Calculated $\gamma_{\mathrm{d}}\left(\mathrm{lb} / \mathrm{ft}^{3}\right)$ & & 100.82 & 0.00 & 99.93 & 100.24 & 100.98 & 101.51 & 99.81 \\
\hline & $\begin{array}{l}\text { Device moisture } \\
\text { content (wt\%) }\end{array}$ & & 19.1 & 3.95 & 19.00 & 19.10 & 19.30 & 19.30 & 19.30 \\
\hline & $\begin{array}{c}\text { Lab moisture content } \\
(\mathrm{wt} \%)\end{array}$ & & 4.16 & 0.00 & 3.26 & 3.15 & 2.90 & 2.58 & 3.57 \\
\hline \multirow{3}{*}{ MDI } & Calculated $\gamma_{\mathrm{d}}\left(\mathrm{lb} / \mathrm{ft}^{3}\right)$ & & & & 123.52 & 0.00 & 0.00 & 123.49 & 123.79 \\
\hline & $\begin{array}{l}\text { Device moisture } \\
\text { content (wt\%) }\end{array}$ & & & & 0.10 & 0.00 & 0.00 & 0.10 & 0.10 \\
\hline & $\begin{array}{c}\text { Lab moisture content } \\
(\mathrm{wt} \%)\end{array}$ & & & & 2.74 & 8.65 & 0.00 & 2.99 & 2.76 \\
\hline \multirow{3}{*}{ EDG } & Calculated $\gamma_{\mathrm{d}}\left(\mathrm{lb} / \mathrm{ft}^{3}\right)$ & & & & 127.67 & 133.40 & 130.74 & 129.12 & 132.64 \\
\hline & $\begin{array}{c}\text { Device moisture } \\
\text { content (wt } \%)\end{array}$ & & & & 2.90 & 2.90 & 2.90 & 3.20 & 4.90 \\
\hline & \begin{tabular}{|c|} 
Lab moisture content \\
(wt $\%)$
\end{tabular} & & & & 3.79 & 3.54 & 3.51 & 3.35 & 2.97 \\
\hline \multirow{3}{*}{ ZFW } & s s (mm) & & & & 1.03 & 1.03 & 0.78 & 0.65 & 1.15 \\
\hline & $\mathrm{E}\left(\mathrm{MN} / \mathrm{m}^{2}\right)$ & & & & 29.20 & 29.30 & 38.30 & 46.20 & 26.10 \\
\hline & $\begin{array}{c}\text { Lab moisture content } \\
(\mathrm{wt} \%)\end{array}$ & & & & 3.73 & 3.74 & 3.69 & 2.98 & 3.82 \\
\hline \multirow{3}{*}{ DFW } & Defl (um) -Avg & & & & 616.33 & 421.33 & 531.67 & 576.67 & 562.33 \\
\hline & Emod (Mpa)- Avg & & & & 42.00 & 57.33 & 50.33 & 51.67 & 50.00 \\
\hline & \begin{tabular}{|c|} 
Lab moisture content \\
$(\mathrm{wt} \%)$
\end{tabular} & & & & 4.47 & 3.45 & 3.16 & 3.19 & 3.35 \\
\hline
\end{tabular}


GP-GM Soil - Test Item 7

\begin{tabular}{|c|c|c|c|c|c|c|c|c|c|}
\hline $\begin{array}{c}\text { Section } \\
2 \\
\end{array}$ & & Base & $\begin{array}{c}\text { Lift 1- } \\
\text { Pass } 8 \\
\end{array}$ & $\begin{array}{c}\text { Lift } 2 \\
\text { Pass } 8 \\
\end{array}$ & $\begin{array}{c}\text { Lift } 3 \\
\text { Pass } 1 \\
\end{array}$ & $\begin{array}{c}\text { Lift } 3 \\
\text { Pass } 2 \\
\end{array}$ & $\begin{array}{c}\text { Lift } 3 \\
\text { Pass } 4 \\
\end{array}$ & $\begin{array}{c}\text { Lift } 3 \\
\text { Pass } 8 \\
\end{array}$ & $\begin{array}{c}\text { Lift } 3 \\
\text { Pass 8W } \\
\end{array}$ \\
\hline \multirow{3}{*}{ NDG } & Calculated $\gamma_{\mathrm{d}}\left(\mathrm{lb} / \mathrm{ft}^{3}\right)$ & 111.01 & 136.60 & 139.34 & 111.51 & 124.37 & 129.78 & 135.91 & 134.64 \\
\hline & $\begin{array}{c}\text { Device moisture } \\
\text { content (wt\%) }\end{array}$ & 10.25 & 3.15 & 3.55 & 3.05 & 3.15 & 2.45 & 2.80 & 2.95 \\
\hline & $\begin{array}{c}\text { Lab moisture content } \\
\text { (wt } \%)\end{array}$ & 11.79 & 3.80 & 3.67 & 15.17 & 3.06 & 2.24 & 2.89 & 3.31 \\
\hline \multirow[b]{2}{*}{ DCP } & Blows/150mm & 0 & 14 & 3.67 & 6.00 & 10.00 & 11.00 & & 22 \\
\hline & \begin{tabular}{|c|}
$\begin{array}{c}\text { Lab moisture content } \\
\text { (wt } \%)\end{array}$ \\
\end{tabular} & 11.79 & 3.80 & 3.67 & 15.17 & 3.06 & 2.24 & 2.89 & 3.31 \\
\hline \multirow{2}{*}{ sS } & Calculated $\gamma_{\mathrm{d}}\left(\mathrm{lb} / \mathrm{ft}^{3}\right)$ & & & & 139.77 & 143.90 & 125.68 & 147.11 & \\
\hline & \begin{tabular}{|c|}
$\begin{array}{c}\text { Lab moisture content } \\
(\mathrm{wt} \%)\end{array}$ \\
\end{tabular} & & & & 3.14 & 3.23 & 2.35 & 2.38 & \\
\hline \multirow{2}{*}{ Clegg } & Impact Value & & & & 14.60 & 26.00 & 19.00 & 29.70 & 24.5 \\
\hline & \begin{tabular}{|c|}
$\begin{array}{c}\text { Lab moisture content } \\
\text { (wt } \%)\end{array}$ \\
\end{tabular} & & & & 3.47 & 2.98 & 3.51 & 2.39 & 3.88 \\
\hline \multirow[b]{2}{*}{ WB } & Calculated $\gamma_{\mathrm{d}}\left(\mathrm{lb} / \mathrm{ft}^{3}\right)$ & & & & 125.00 & 126.95 & 135.68 & 118.81 & \\
\hline & \begin{tabular}{|c|}
$\begin{array}{c}\text { Lab moisture content } \\
\text { (wt } \%)\end{array}$ \\
\end{tabular} & & & & 2.49 & 3.03 & 2.63 & 2.31 & \\
\hline \multirow[b]{2}{*}{ SC } & Calculated $\gamma_{\mathrm{d}}\left(\mathrm{lb} / \mathrm{ft}^{3}\right)$ & & & & 125.73 & 133.82 & 132.47 & 134.76 & \\
\hline & \begin{tabular}{|c|}
$\begin{array}{c}\text { Lab moisture content } \\
\text { (wt } \%)\end{array}$ \\
\end{tabular} & & & & 3.06 & 3.03 & 2.67 & 2.28 & \\
\hline \multirow{3}{*}{ GG } & Modulus (ksi) -Avg & & & & 12.93 & 16.45 & 15.21 & 15.71 & 16.23 \\
\hline & $\begin{array}{c}\text { Stiffness (kip/in.) - } \\
\text { Avg }\end{array}$ & & & & 58.67 & 74.63 & 68.97 & 71.24 & 73.61 \\
\hline & $\begin{array}{c}\text { Lab moisture content } \\
(\mathrm{wt} \%)\end{array}$ & & & & 3.93 & 3.01 & 2.77 & 2.61 & 3.52 \\
\hline \multirow{3}{*}{ SDG } & Calculated $\gamma_{\mathrm{d}}\left(\mathrm{lb} / \mathrm{ft}^{3}\right)$ & & 101.52 & 0.00 & 99.66 & 101.69 & 101.19 & 102.81 & 110.65 \\
\hline & $\begin{array}{c}\text { Device moisture } \\
\text { content (wt } \%)\end{array}$ & & 19.1 & 3.75 & 19.00 & 19.30 & 19.30 & 19.40 & 19.30 \\
\hline & \begin{tabular}{|c|}
$\begin{array}{c}\text { Lab moisture content } \\
\text { (wt } \%)\end{array}$ \\
\end{tabular} & & 4.05 & 0.00 & 3.80 & 2.6 & 2.98 & 2.09 & 3.19 \\
\hline \multirow{3}{*}{ MDI } & Calculated $\gamma_{\mathrm{d}}\left(\mathrm{lb} / \mathrm{ft}^{3}\right)$ & & & & 123.06 & & & 125.96 & 123.10 \\
\hline & $\begin{array}{c}\text { Device moisture } \\
\text { content (wt\%) }\end{array}$ & & & & 0.10 & 0.00 & 0.00 & 1.50 & 0.40 \\
\hline & \begin{tabular}{|c|}
$\begin{array}{c}\text { Lab moisture content } \\
(\mathrm{wt} \%)\end{array}$ \\
\end{tabular} & & & & 3.41 & 9.30 & 0.00 & 2.81 & 3.83 \\
\hline \multirow{3}{*}{ EDG } & Calculated $\gamma_{\mathrm{d}}\left(\mathrm{lb} / \mathrm{ft}^{3}\right)$ & & & & 127.94 & 130.90 & 130.51 & 126.11 & 129.07 \\
\hline & $\begin{array}{c}\text { Device moisture } \\
\text { content (wt } \% \text { ) }\end{array}$ & & & & 3.10 & 2.50 & 3.00 & 2.90 & 3.70 \\
\hline & \begin{tabular}{|c|}
$\begin{array}{c}\text { Lab moisture content } \\
(\mathrm{wt} \%)\end{array}$ \\
\end{tabular} & & & & 3.73 & 3.04 & 3.68 & 2.92 & 3.32 \\
\hline \multirow{3}{*}{ ZFW } & $\mathrm{s}(\mathrm{mm})$ & & & & 0.85 & 0.55 & 0.66 & 0.66 & 1.05 \\
\hline & $\mathrm{E}\left(\mathrm{MN} / \mathrm{m}^{2}\right)$ & & & & 35.50 & 54.80 & 45.80 & 45.70 & 28.50 \\
\hline & \begin{tabular}{|c|}
$\begin{array}{c}\text { Lab moisture content } \\
(\mathrm{wt} \%)\end{array}$ \\
\end{tabular} & & & & 3.07 & 3.83 & 3.46 & 3.76 & 3.12 \\
\hline \multirow{3}{*}{ DFW } & Defl (um) -Avg & & & & 827.67 & 924.00 & 863.00 & 470.33 & 592.67 \\
\hline & Emod (Mpa)- Avg & & & & 38.33 & 33.67 & 39.67 & 56.67 & 48.33 \\
\hline & \begin{tabular}{|c|}
$\begin{array}{c}\text { Lab moisture content } \\
(\mathrm{wt} \%)\end{array}$ \\
\end{tabular} & & & & 3.53 & 2.85 & 2.74 & 3.31 & 4.29 \\
\hline
\end{tabular}


GP-GM Soil - Test Item 7

\begin{tabular}{|c|c|c|c|c|c|c|c|c|c|}
\hline $\begin{array}{c}\text { Section } \\
3 \\
\end{array}$ & & Base & $\begin{array}{c}\text { Lift 1- } \\
\text { Pass } 8 \\
\end{array}$ & $\begin{array}{c}\text { Lift } 2 \\
\text { Pass } 8 \\
\end{array}$ & $\begin{array}{c}\text { Lift } 3 \\
\text { Pass } 1 \\
\end{array}$ & $\begin{array}{c}\text { Lift } 3 \\
\text { Pass } 2 \\
\end{array}$ & $\begin{array}{c}\text { Lift } 3 \\
\text { Pass } 4 \\
\end{array}$ & $\begin{array}{c}\text { Lift } 3 \\
\text { Pass } 8 \\
\end{array}$ & $\begin{array}{c}\text { Lift } 3 \\
\text { Pass 8W } \\
\end{array}$ \\
\hline \multirow{3}{*}{ NDG } & Calculated $\gamma_{\mathrm{d}}\left(\mathrm{lb} / \mathrm{ft}^{3}\right)$ & 125.85 & 136.75 & 138.78 & 128.79 & 128.08 & 135.03 & 135.71 & 137.08 \\
\hline & $\begin{array}{c}\text { Device moisture } \\
\text { content (wt\%) }\end{array}$ & 14.50 & 3.15 & 3.20 & 3.35 & 3.10 & 2.70 & 2.75 & 3.15 \\
\hline & $\begin{array}{c}\text { Lab moisture content } \\
\text { (wt } \%)\end{array}$ & 3.82 & 3.66 & 3.49 & 3.49 & 3.12 & 2.40 & 3.13 & 3.16 \\
\hline \multirow[b]{2}{*}{ DCP } & Blows/150mm & 0 & 11 & 3.49 & 4.00 & 7.00 & 8.00 & 0.00 & 20 \\
\hline & \begin{tabular}{|c|}
$\begin{array}{c}\text { Lab moisture content } \\
\text { (wt } \%)\end{array}$ \\
\end{tabular} & 3.82 & 3.66 & 3.49 & 3.49 & 3.12 & 2.40 & 3.13 & 3.16 \\
\hline \multirow{2}{*}{ sS } & Calculated $\gamma_{\mathrm{d}}\left(\mathrm{lb} / \mathrm{ft}^{3}\right)$ & & & & 133.17 & 143.95 & 134.28 & 114.37 & \\
\hline & $\begin{array}{c}\text { Lab moisture content } \\
\text { (wt } \%)\end{array}$ & & & & 2.87 & 2.80 & 2.20 & 2.16 & \\
\hline \multirow{2}{*}{ Clegg } & Impact Value & & & & 17.00 & 16.00 & 18.70 & 23.80 & 24 \\
\hline & \begin{tabular}{|c|}
$\begin{array}{c}\text { Lab moisture content } \\
\text { (wt } \%)\end{array}$ \\
\end{tabular} & & & & 2.87 & 2.78 & 3.20 & 2.64 & Not avail. \\
\hline \multirow[b]{2}{*}{ WB } & Calculated $\gamma_{\mathrm{d}}\left(\mathrm{lb} / \mathrm{ft}^{3}\right)$ & & & & & 130.68 & 133.29 & 117.61 & \\
\hline & $\begin{array}{c}\begin{array}{c}\text { Lab moisture content } \\
\text { (wt } \%)\end{array} \\
\end{array}$ & & & & 2.86 & 6.71 & 2.95 & 1.72 & \\
\hline \multirow[b]{2}{*}{ SC } & Calculated $\gamma_{\mathrm{d}}\left(\mathrm{lb} / \mathrm{ft}^{3}\right)$ & & & & 132.95 & 132.19 & 139.23 & 138.58 & \\
\hline & \begin{tabular}{|c|}
$\begin{array}{c}\text { Lab moisture content } \\
\text { (wt } \%)\end{array}$ \\
\end{tabular} & & & & 2.67 & 6.71 & 2.50 & 2.48 & \\
\hline \multirow{3}{*}{ GG } & Modulus (ksi) -Avg & & & & 14.01 & 15.05 & 13.87 & 12.75 & 17.28 \\
\hline & $\begin{array}{c}\text { Stiffness (kip/in.) - } \\
\text { Avg }\end{array}$ & & & & 63.54 & 68.24 & 62.89 & 57.83 & 86.24 \\
\hline & $\begin{array}{c}\text { Lab moisture content } \\
(\mathrm{wt} \%)\end{array}$ & & & & 3.64 & 2.79 & 3.11 & 2.87 & 3.06 \\
\hline \multirow{3}{*}{ SDG } & Calculated $\gamma_{\mathrm{d}}\left(\mathrm{lb} / \mathrm{ft}^{3}\right)$ & & 100.36 & 0.00 & 102.10 & 101.09 & 100.49 & 101.63 & 99.21 \\
\hline & $\begin{array}{c}\text { Device moisture } \\
\text { content (wt } \%)\end{array}$ & & 18.9 & 3.26 & 19.30 & 19.20 & 19.20 & 19.30 & 19.30 \\
\hline & \begin{tabular}{|c|}
$\begin{array}{c}\text { Lab moisture content } \\
\text { (wt } \%)\end{array}$ \\
\end{tabular} & & 3.69 & 0.00 & 2.11 & 3.08 & 3.19 & 2.28 & 4.51 \\
\hline \multirow{3}{*}{ MDI } & Calculated $\gamma_{\mathrm{d}}\left(\mathrm{lb} / \mathrm{ft}^{3}\right)$ & & & & 123.19 & 0.00 & 0.00 & 124.85 & 123.44 \\
\hline & $\begin{array}{c}\text { Device moisture } \\
\text { content (wt } \%)\end{array}$ & & & & 0.10 & 0.00 & 0.00 & 1.00 & 0.10 \\
\hline & \begin{tabular}{|c|}
$\begin{array}{c}\text { Lab moisture content } \\
(\mathrm{wt} \%)\end{array}$ \\
\end{tabular} & & & & 3.15 & 9.23 & 0.00 & 3.14 & 3.11 \\
\hline \multirow{3}{*}{ EDG } & Calculated $\gamma_{\mathrm{d}}\left(\mathrm{lb} / \mathrm{ft}^{3}\right)$ & & & & 126.90 & 131.22 & 127.56 & 132.24 & 129.84 \\
\hline & $\begin{array}{c}\text { Device moisture } \\
\text { content (wt } \% \text { ) }\end{array}$ & & & & 2.70 & 2.70 & 2.60 & 3.90 & 3.40 \\
\hline & \begin{tabular}{|c|}
$\begin{array}{c}\text { Lab moisture content } \\
\text { (wt } \%)\end{array}$ \\
\end{tabular} & & & & 3.79 & 3.30 & 3.36 & 3.26 & 2.89 \\
\hline \multirow{3}{*}{ ZFW } & $\mathrm{s}(\mathrm{mm})$ & & & & 0.94 & 1.12 & 0.85 & 1.10 & 0.77 \\
\hline & $\mathrm{E}\left(\mathrm{MN} / \mathrm{m}^{2}\right)$ & & & & 32.00 & 26.80 & 35.30 & 27.40 & 39.00 \\
\hline & \begin{tabular}{|c|}
$\begin{array}{c}\text { Lab moisture content } \\
\text { (wt } \%)\end{array}$ \\
\end{tabular} & & & & 3.48 & 3.50 & 3.33 & 3.07 & 3.47 \\
\hline \multirow{3}{*}{ DFW } & Defl (um) -Avg & & & & 1163.33 & 1073.00 & 1010.00 & 820.67 & 793.67 \\
\hline & Emod (Mpa)- Avg & & & & 29.67 & 31.67 & 33.67 & 39.67 & 42.67 \\
\hline & \begin{tabular}{|c|}
$\begin{array}{c}\text { Lab moisture content } \\
(\mathrm{wt} \%)\end{array}$ \\
\end{tabular} & & & & 3.95 & 3.18 & 3.01 & 3.39 & 3.44 \\
\hline
\end{tabular}


GP-GM Soil - Test Item 7

\begin{tabular}{|c|c|c|c|c|c|c|c|c|c|}
\hline $\begin{array}{c}\text { Section } \\
4 \\
\end{array}$ & & Base & $\begin{array}{l}\text { Lift 1- } \\
\text { Pass } 8 \\
\end{array}$ & $\begin{array}{c}\text { Lift } 2 \\
\text { Pass } 8 \\
\end{array}$ & $\begin{array}{l}\text { Lift } 3 \\
\text { Pass } 1 \\
\end{array}$ & $\begin{array}{c}\text { Lift } 3 \\
\text { Pass } 2 \\
\end{array}$ & $\begin{array}{l}\text { Lift } 3 \\
\text { Pass } 4 \\
\end{array}$ & $\begin{array}{l}\text { Lift } 3 \\
\text { Pass } 8 \\
\end{array}$ & $\begin{array}{c}\text { Lift } 3 \\
\text { Pass } 8 \mathrm{~W} \\
\end{array}$ \\
\hline \multirow{3}{*}{ NDG } & $\begin{array}{c}\text { Calculated } \gamma_{\mathrm{d}} \\
\left(\mathrm{lb} / \mathrm{ft}^{3}\right)\end{array}$ & 124.54 & 140.61 & 136.91 & 126.85 & 126.91 & 134.67 & 133.97 & 136.57 \\
\hline & $\begin{array}{c}\text { Device moisture } \\
\text { content (wt \%) }\end{array}$ & 9.95 & 3.55 & 3.30 & 2.95 & 2.35 & 2.45 & 2.50 & 2.90 \\
\hline & $\begin{array}{c}\text { Lab moisture } \\
\text { content (wt\%) }\end{array}$ & 8.26 & 3.53 & 3.62 & 3.13 & 2.68 & 2.80 & 2.60 & 3.55 \\
\hline \multirow[b]{2}{*}{ DCP } & "Blows/150mm & 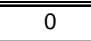 & 12 & 3.62 & 6.00 & 6.00 & 12.00 & 0.00 & 15 \\
\hline & $\begin{array}{l}\text { Lab moisture } \\
\text { content (wt\%) }\end{array}$ & 8.26 & 3.53 & 3.62 & 3.13 & 2.68 & 2.80 & 2.60 & 3.55 \\
\hline \multirow{2}{*}{ ss } & $\begin{array}{c}\text { Calculated } \gamma_{\mathrm{d}} \\
\left(\mathrm{b} / \mathrm{ft}^{3}\right)\end{array}$ & & & & 134.89 & 144.28 & 124.02 & 138.98 & \\
\hline & $\begin{array}{l}\text { Lab moisture } \\
\text { content (wt\%) }\end{array}$ & & & & 2.75 & 3.23 & 1.73 & 2.13 & \\
\hline \multirow[b]{2}{*}{ Clegg } & Impact Value & & & & 16.00 & 17.30 & 20.70 & 27.00 & 18 \\
\hline & $\begin{array}{l}\text { Lab moisture } \\
\text { content (wt\%) }\end{array}$ & & & & 2.85 & 3.02 & 3.19 & 2.54 & 3.11 \\
\hline \multirow{2}{*}{ WB } & $\begin{array}{c}\text { Calculated } \gamma_{\mathrm{d}} \\
\left(\mathrm{lb} / \mathrm{ft}^{3}\right) \\
\end{array}$ & & & & 124.66 & 127.66 & 119.15 & 113.20 & \\
\hline & $\begin{array}{l}\text { Lab moisture } \\
\text { content (wt\%) }\end{array}$ & & & & 2.78 & 3.05 & 2.60 & 2.96 & \\
\hline \multirow{2}{*}{ SC } & $\begin{array}{c}\text { Calculated } \gamma_{\mathrm{d}} \\
\left(\mathrm{lb} / \mathrm{ft}^{3}\right) \\
\end{array}$ & & & & 44.94 & 132.53 & 130.88 & 138.20 & \\
\hline & $\begin{array}{l}\text { Lab moisture } \\
\text { content (wt\%) }\end{array}$ & & & & 67.22 & 3.05 & 2.33 & 5.08 & \\
\hline \multirow{3}{*}{ GG } & Modulus (ksi) - Avg & & & & 13.44 & 14.61 & 13.07 & 14.42 & 14.96 \\
\hline & \begin{tabular}{|c|}
$\begin{array}{c}\text { Stiffness (kip/in.) - } \\
\text { Avg }\end{array}$ \\
\end{tabular} & & & & 59.45 & 66.27 & 59.26 & 65.41 & 67.81 \\
\hline & $\begin{array}{l}\text { Lab moisture } \\
\text { content (wt } \%)\end{array}$ & & & & 3.25 & 3.31 & 2.62 & 2.64 & 3.54 \\
\hline \multirow{3}{*}{ SDG } & $\begin{array}{c}\text { Calculated } \gamma_{\mathrm{d}} \\
\left(\mathrm{lb} / \mathrm{ft}^{3}\right)\end{array}$ & & 102.15 & 0.00 & 99.86 & 100.90 & 100.86 & 101.64 & 99.93 \\
\hline & $\begin{array}{c}\text { Device moisture } \\
\text { content (wt\%) }\end{array}$ & & 19.2 & 3.39 & 18.90 & 19.20 & 19.30 & 19.30 & 19.20 \\
\hline & $\begin{array}{c}\text { Lab moisture } \\
\text { content (wt } \%)\end{array}$ & & 3.54 & 0.00 & 3.33 & 2.89 & 3.02 & 2.55 & 3.17 \\
\hline \multirow{3}{*}{ MDI } & $\begin{array}{c}\text { Calculated } \gamma_{\mathrm{d}} \\
\left(\mathrm{lb} / \mathrm{ft}^{3}\right)\end{array}$ & & & & 123.91 & 0.00 & 0.00 & 126.53 & 123.76 \\
\hline & $\begin{array}{c}\text { Device moisture } \\
\text { content (wt\%) }\end{array}$ & & & & 0.10 & 0.00 & 0.00 & 2.00 & 0.10 \\
\hline & $\begin{array}{l}\text { Lab moisture } \\
\text { content (wt\%) } \\
\end{array}$ & & & & 2.66 & 9.61 & 0.00 & 2.97 & 2.86 \\
\hline \multirow{3}{*}{ EDG } & $\begin{array}{c}\text { Calculated } \gamma_{\mathrm{d}} \\
\left(\mathrm{lb} / \mathrm{ft}^{3}\right) \\
\end{array}$ & & & & 124.27 & 129.32 & 129.33 & 127.44 & 128.68 \\
\hline & $\begin{array}{l}\text { Device moisture } \\
\text { content (wt\%) }\end{array}$ & & & & 2.20 & 2.40 & 2.70 & 3.40 & 4.80 \\
\hline & $\begin{array}{l}\text { Lab moisture } \\
\text { content (wt } \%)\end{array}$ & & & & 2.99 & 3.06 & 3.12 & 2.64 & 3.39 \\
\hline \multirow{3}{*}{ ZFW } & s (mm) & & & & 0.92 & 1.14 & 1.07 & 1.45 & 1.72 \\
\hline & $\mathrm{E}\left(\mathrm{MN} / \mathrm{m}^{2}\right)$ & & & & 32.60 & 26.20 & 28.10 & 20.70 & 17.40 \\
\hline & $\begin{array}{l}\text { Lab moisture } \\
\text { content (wt\%) }\end{array}$ & & & & 3.67 & 3.87 & 2.89 & 2.57 & 3.98 \\
\hline \multirow{3}{*}{ DFW } & Defl (um) - Avg & & & & 1181.00 & 1011.33 & 1180.00 & 816.67 & "640.33 \\
\hline & Emod (Mpa)- Avg & & & & 29.00 & 35.33 & 28.67 & 42.33 & 48.67 \\
\hline & $\begin{array}{l}\text { Lab moisture } \\
\text { content (wt\%) }\end{array}$ & & & & 3.78 & 3.39 & 2.89 & 2.73 & 3.39 \\
\hline
\end{tabular}




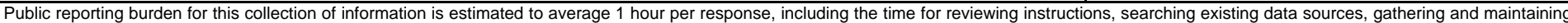

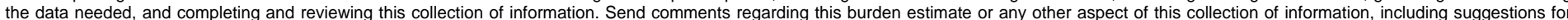

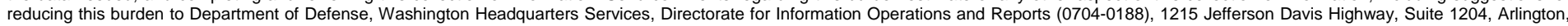

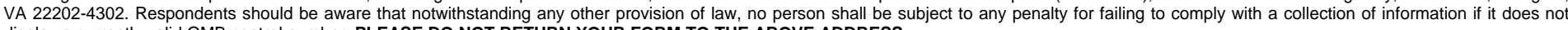
display a currently valid OMB control number. PLEASE DO NOT RETURN YOUR FORM TO THE ABOVE ADDRESS.
1. REPORT DATE (DD-MM-YYYY)
March 2013
Final report

\section{TITLE AND SUBTITLE}

Non-Nuclear Alternatives to Monitoring Moisture-Density Response in Soils

3. DATES COVERED (From - To)

5a. CONTRACT NUMBER

5b. GRANT NUMBER

5c. PROGRAM ELEMENT NUMBER

5d. PROJECT NUMBER

5e. TASK NUMBER

5f. WORK UNIT NUMBER

8. PERFORMING ORGANIZATION REPORT NUMBER

ERDC/GSL TR-13-6

U.S. Army Engineer Research and Development Center

Geotechnical and Structures Laboratory

3909 Halls Ferry Road

Vicksburg, MS 39180-6199

9. SPONSORING / MONITORING AGENCY NAME(S) AND ADDRESS(ES)

U.S. Army Corps of Engineers

Washington, DC 20314-1000

10. SPONSOR/MONITOR'S ACRONYM(S)

11. SPONSOR/MONITOR'S REPORT NUMBER(S)

\section{DISTRIBUTION / AVAILABILITY STATEMENT}

Approved for public release; distribution is unlimited.

\section{SUPPLEMENTARY NOTES}

\section{ABSTRACT}

During the period May-August 2010, researchers of the U.S. Army Engineer Research and Development Center in Vicksburg, MS, tested the effectiveness of various devices to determine the dry density, or modulus, of soils for horizontal construction. These tests were conducted to determine a usable alternative to the soil nuclear density gauge. The accuracy and precision of the different testing devices were compared to the density values obtained from the soil nuclear density gauge. The devices and techniques that were tested are grouped into four broad families: nuclear, electrical, volume replacement, and modulus-based. The nuclear device was the nuclear density gauge that was included for comparison purposes. Electrical devices that were tested were the electrical density gauge, the moisture + density indicator, and the soil density gauge. Volume replacement density-determining techniques; were the sand cone, the steel shot, and the water balloon tests. Modulus-based devices were two different lightweight deflectometers, a dynamic cone penetrometer, the Clegg hammer, and the GeoGauge. This investigation consisted of full-scale construction of seven soils representing a range of materials encountered in operational construction activities. Soils ranged from fine-grained silts and clays to coarse-grained gravels and crushed limestone. The test results indicated that the soil density gauge corrected with a sand cone density measurement, demonstrated the optimal combination of precision and accuracy compared to the nuclear density gauge.

Results of the tests are presented and include (a) comparisons of the dry densities of the various devices to the reported dry densities of the nuclear gauge, (b) ranking of the density devices according to agreement with the nuclear density gauge, and (c) field results of modulusbased devices. Results will be used to provide further guidance for selection of appropriate devices for field determination of soil density.

\begin{tabular}{|c|c|c|c|c|c|}
\hline \multicolumn{2}{|l|}{ 15. SUBJECT TERMS } & \multicolumn{2}{|l|}{ Field density } & \multicolumn{2}{|c|}{ Sand cone } \\
\hline \multicolumn{2}{|l|}{ Density } & \multicolumn{2}{|l|}{ Non-destructive } & \multicolumn{2}{|l|}{ Soil } \\
\hline \multicolumn{2}{|l|}{ Electronic } & Non-nuclear & \multicolumn{3}{|c|}{ Water content } \\
\hline \multicolumn{3}{|c|}{ 16. SECURITY CLASSIFICATION OF: } & $\begin{array}{l}\text { 17. LIMITATION } \\
\text { OF ABSTRACT }\end{array}$ & $\begin{array}{l}\text { 18. NUMBER } \\
\text { OF PAGES }\end{array}$ & $\begin{array}{l}\text { 19a. NAME OF RESPONSIBLE } \\
\text { PERSON }\end{array}$ \\
\hline $\begin{array}{l}\text { a. REPORT } \\
\text { UNCLASSIFIED }\end{array}$ & $\begin{array}{l}\text { b. ABSTRACT } \\
\text { UNCLASSIFIED }\end{array}$ & $\begin{array}{l}\text { c. THIS PAGE } \\
\text { UNCLASSIFIED }\end{array}$ & & 114 & $\begin{array}{l}\text { 19b. TELEPHONE NUMBER (include } \\
\text { area code) }\end{array}$ \\
\hline
\end{tabular}

